\title{
Post-Conflict Occupations: A New Analysis Using Comparisons of Contextual, Hybrid and Instigated Factors in Germany, Japan and Iraq
}

L. Amber Brugnoli

Follow this and additional works at: https://researchrepository.wvu.edu/etd

\section{Recommended Citation}

Brugnoli, L. Amber, "Post-Conflict Occupations: A New Analysis Using Comparisons of Contextual, Hybrid and Instigated Factors in Germany, Japan and Iraq" (2017). Graduate Theses, Dissertations, and Problem Reports. 5272.

https://researchrepository.wvu.edu/etd/5272

This Dissertation is protected by copyright and/or related rights. It has been brought to you by the The Research Repository @ WVU with permission from the rights-holder(s). You are free to use this Dissertation in any way that is permitted by the copyright and related rights legislation that applies to your use. For other uses you must obtain permission from the rights-holder(s) directly, unless additional rights are indicated by a Creative Commons license in the record and/ or on the work itself. This Dissertation has been accepted for inclusion in WVU Graduate Theses, Dissertations, and Problem Reports collection by an authorized administrator of The Research Repository @ WVU.

For more information, please contact researchrepository@mail.wvu.edu. 


\title{
Post-Conflict Occupations: \\ A New Analysis Using Comparisons of Contextual, Hybrid \& Instigated Factors In \\ Germany, Japan \& Iraq
}

\author{
L. Amber Brugnoli
}

Dissertation Submitted to the Eberly College of Arts and Sciences at West Virginia University in partial fulfillment of the requirements for the degree of

\author{
Doctor of Philosophy \\ In \\ Political Science \\ Scott Crichlow, PhD - Chair \\ Robert Duval, PhD \\ James Friedberg, JD \\ Joe D. Hagan, PhD \\ Patrick Hickey, PhD \\ Department of Political Science \\ Morgantown, WV
}

2017

Keywords: post-conflict occupation, reconstruction, civil affairs, military government Copyright 2017 L. Amber Brugnoli 


\author{
Abstract \\ Post-Conflict Occupations: \\ A New Analysis Using Comparisons of Contextual, Hybrid \& Instigated Factors \\ In \\ Germany, Japan \& Iraq
}

\title{
L. Amber Brugnoli
}

This research asserts that the failures in reconstructing Iraq resulted from poor decision-making and policy implementation in 2003 by comparing those efforts to the successful rebuilding of Germany and Japan, post-World War II. The focus is on actions taken by the occupying force-the United Stateswithin the first 12 months of the operation, with a five-year post-conflict examination to determine the result of those actions. While comparisons between Iraq and Germany or Iraq and Japan have been completed previously, they are often with the intent of proving why the reconstruction of Iraq did not succeed by highlighting the differences between the two nations at issue; however, when a three-nation cross-comparison is done, Iraq does not vary from the post-World War II nations as widely as is popularly believed. The current comparison is performed through an examination of three categories of factors, two of which have been previously examined at length by scholars. The categories are Contextual Factors, Hybrid Factors, and Instigated Factors. For each category, the U.S. had an increasing level of control over the situation on the ground. The Instigated Factors have not previously been subjected to a comparative analysis. This research closes the gap in previous works by illustrating what the U.S. knew, or should have known, in Iraq based on earlier reconstruction attempts; by highlighting the fact similar obstacles to those faced in Iraq were successfully overcome during prior efforts; and by identifying those factors most influential to the success of post-conflict reconstruction efforts. 


\section{Dedication}

This work is dedicated to the Iraqi men and women I met while serving in their country-specifically to my amazing investigative team of "Little Big Mac".

Though I left your country, I did not forget you.

Also, for people like my grandfather, who left to fight a war in a far-off land I would one day call home, in hopes of making the world a better place.

I have enjoyed amazing opportunities because of their sacrifices. 


\section{Acknowledgements}

In any work such as this-a project spanning several years-countless individuals will contribute and inspire along the way. I cannot hope to remember everyone who discussed and debated this topic with me, but for those who stuck with it, thank you.

To my Task Force 134 colleagues, who, in an Iraqi Dining Facility, quipped that someone should write about what we did there, and who could also be counted on for a timely Princess Bride quote.

To my committee chair and advisor, Prof Scott Crichlow, who told me research does not have to be filled with numbers and statistics to make a meaningful contribution to the field.

To Prof James Friedberg, thanks for the line edits and your 20 years of friendship-I love that you are now my co-worker, Jim!

To my incredibly supportive supervisor, Associate Dean Gregory Elkins-thanks for asking every week how many pages I'd written.

To WVU Law Prof Kirsha Trychta, for inviting me to join her writing group, and to all the other Avengers-you pushed me to the finish line!

To my husband, Eric, for his love, support, and patience. I'm really glad we decided to "get out of Dodge" together.

Finally, to my beautiful daughters, Kaitlyn and Adalind: may this work show you that, no matter how long it takes, you should never give up on a dream. 
Table of Contents

Abstract $\quad$ ii

Dedication iii

Acknowledgements $\quad$ iv

Table of Contents $\quad$ V

List of Acronyms vii

List of Players viii

$\begin{array}{ll}\text { Chapter } 1 \text { - Introduction } & 1\end{array}$

Chapter 2 - Literature Review 9

- Nation-Building 9

- Insurgency 12

- Previous Analyses 16

- Contextual Factors (Category 1) 21

- Hybrid Factors (Category 2) 24

- Instigated Factors (Category 3) 29

- Summary 34

Chapter 3 - Contextual Factors: Germany, Japan and Iraq 36

- Historical Precedent w/ Democracy 36

- Societal Cohesion 39

- Exhaustion 45

- External Enemies $\quad 50$

Chapter 4 - Hybrid Factors: Germany, Japan and Iraq 53

- Economic Development 53

- Legitimacy of Occupation 72

- Consistency of Authority 83

- Security 97

- Civil Institutions 113

$\begin{array}{ll}\text { Chapter } 5 \text { - Instigated Factors } & 146\end{array}$

- Operational Planning 146

- Approach to Civil Affairs 158

- Occupation Policy Decisions 187

- Elections and Constitutional Drafting 212 
Chapter 6-Germany, Japan and Iraq: Five-Year Post-Conflict Status

Note on Economic Costs

263

Chapter 7 - Findings and Recommendations

266

- Conclusions

279

Bibliography

283 


\section{List of Acronyms}

$\begin{array}{ll}\text { AQI } & \text { Al Qaeda in Iraq } \\ \text { CENTCOM } & \text { Central Command - the U.S. headquarters responsible for Southwest Asia operations } \\ \text { CFLCC } & \text { Combined Forces Land Component Commander - person overseeing the ground battle } \\ \text { COIN } & \text { Counter-Insurgency } \\ \text { CPA } & \text { Coalition Provisional Authority - the governing body during Iraq's occupation } \\ \text { DoD } & \text { Department of Defense (U.S.) } \\ \text { FID } & \text { Foreign Internal Defense - mission to secure areas of operation } \\ \text { GARIOA } & \text { Government Aid and Relief in Occupied Areas - the aid program used in Germany, 1945 } \\ \text { JAM } & \text { Jaish al Mahdi - the militarized arm of Muqtada al Sadr's forces } \\ \text { JCS } & \text { Joint Chiefs of Staff (U.S.) } \\ \text { IGC } & \text { Iraqi (or Interim) Governing Council; also referred to as GC } \\ \text { IRDC } & \text { Iraq Reconstruction and Development Council } \\ \text { ISF } & \text { Iraqi Security Forces } \\ \text { NSC } & \text { National Security Council } \\ \text { NSPD } & \text { National Security Policy Directive } \\ \text { OIF } & \text { Operation: IRAQI FREEDOM } \\ \text { OMGUS } & \text { Office of Military Government, United States (Germany, 1945) } \\ \text { OPLAN } & \text { Operations Plan } \\ \text { ORHA } & \text { Office of Reconstruction and Humanitarian Assistance - short-lived precursor to the CPA } \\ \text { SCAP } & \text { Supreme Commander, Allied Powers (MacArthur in Japan, 1945) } \\ \text { SCIRI } & \text { Supreme Council for the Islamic Revolution in Iraq - Shia political party } \\ \text { SF } & \text { Special Forces (U.S.) } \\ \text { SHAEF } & \text { Supreme Headquarters, Allied Expeditionary Force (Germany, 1945) } \\ \text { TAL } & \text { Transitional Administrative Law - temporary law during Iraq's transition to sovereignty } \\ \text { USAID } & \text { United States Agency for International Development }\end{array}$




\section{List of Players}

Ayad Allawi - selected by the CPA to serve as interim Prime Minister of Iraq in 2004

Stuart Bowen - appointed Special Inspector General for Iraq Reconstruction by President Bush in 2004

Lakhdar Brahimi - UN Special Envoy to Iraq in 2004

Paul Bremer - Ambassador; Head of the Coalitional Provisional Authority

Ahmed Chalabi - leader of the Iraq National Conference, a group of exiled politicians; the Bush Administration's preferred choice for the position of Iraq's new leader

Lucius Clay - General; commander of U.S. occupation forces in Germany

Larry Diamond - political scientists and advisor to the CPA for Iraq's new constitution

Dwight Eisenhower - Commanding General of U.S. forces in Europe, 1945

Douglas Feith - Under Secretary of Defense and senior policy advisor during Iraq's occupation

Tommy Franks - General; CENTCOM commander during the Iraq invasion

Jay Garner - Retired General; head of the short-lived ORHA, precursor to the Bremer and the CPA

Zalmay Khalilzad - experienced Middle East diplomat; removed from occupation team by Bremer, later became U.S. Ambassador to Iraq

David Kilcullen - Australian counter-insurgency expert who became frequent advisor to General Petraeus

Douglas MacArthur - General; Supreme Commander, Allied Powers in Japan, 1945

Nuri al-Maliki - Iraq's first permanent elected Prime Minister, 2005

Sergio de Mello - first UN Envoy in Iraq; killed by a truck bomb in August 2003

Raymond Odierno - General; commander of the $4^{\text {th }}$ Infantry Division during the Iraq invasion, later became commander of Multi-National Forces - Iraq and eventually U.S. Army Chief of Staff

Peter Pace - General; Chairman of the Joint Chiefs of Staff during the Iraq invasion

Adnan Pachachi - preferred choice to serve as Iraq's Interim president, but became disillusioned with the CPA and rejected the position

David Petraeus - General; commander of the $101^{\text {st }}$ Airborne Division during the Iraq invasion and later returned as commander, Multi-National Forces-Iraq; the U.S. Army's chief counter-insurgency expert 
Colin Powell - Secretary of State in 2003

Condoleeza Rice - National Security Advisor in 2003

Donald Rumsfeld - Secretary of Defense in 2003

Muqtada al Sadr - self-proclaimed cleric who led the most sustained insurgency against occupation forces in Iraq

Eric Shinseki - Army Chief of Staff in 2003

Ali al-Sistani - most influential Shia cleric in Iraq in 2003-04; an opponent of the occupation who desired greater UN involvement in Iraq

Walter Slocombe - Under Secretary of Defense and Paul Bremer's chief policy advisor

Paul Wolfowitz - Deputy Secretary of Defense in 2003

Anthony Zinni - General; CENTCOM commander in the late 1990s and chief architect of the discarded plans to respond to the fall of Baathism in Iraq 


\section{CHAPTER 1 \\ INTRODUCTION}

"There was a time when many said that the cultures of Japan and Germany were incapable of sustaining democratic values. Well, they were wrong. Some say the same of Iraq today. They are mistaken. The nation of Iraq-with its proud heritage, abundant resources, and skilled and educated people-is fully capable of moving towards democracy and living in freedom."

- President George W. Bush

February 26, 2003

The post-World War II occupations of Germany and Japan were America's first experiences with the use of military force to push a transition to democracy in the aftermath of conflict. The success of these endeavors demonstrated democracy was transferable and set a standard for post-conflict nationbuilding yet to be matched. (Dobbins, et al, 2003: xiii) Following the invasion of Iraq in 2003, the United States was once again offered the opportunity to replicate its transformation of the former Axis powers into stable democracies. Not since 1945 had the U.S. taken on such an ambitious task: the occupation of a sizable country and a stated commitment to wholesale political evolution.

The United States was clearly the strong side in the fight for Iraq. It is not only the most powerful state in the world, it also enjoyed conventional military supremacy and a large numerical troop advantage over the insurgents it faced. But at the end of its first 12 months in Iraq, the U.S. military began to confront the fact it had suffered its first significant setback since the Vietnam War. Iraq's security situation had worsened and essential services still were not restored. Some 300,000 American troops had served in-country, and many would be going back for a second tour. There was little to show for this effort other than 800 dead troops and more than 5,000 wounded. (Ricks, 2007: 363)

When the true war for Iraq began in the summer of 2003, U.S. commanders were surprised by the intensity and duration of the resistance to their presence. The emphasis was on capturing and killing their enemies, but every time key leaders were contained, more seemed to spring up. (Ricks, 2009: 161-62) By 2007, the U.S. military had been fighting in Iraq longer than it fought in World War II, 
despite trying everything in its toolbox to win a conventional outcome against an unconventional enemy. As early as 2004, the intelligence community concluded the invasion had turned Iraq into a new breeding ground for a fresh generation of tougher, more professional, Islamic terrorists (Ricks, 2007: 378).

Soon after the Bush administration revealed its plan to overthrow Saddam Hussein and bring democracy to Iraq, commentators began comparing this initiative to America's occupation of Germany and Japan following World War II. Starting in the autumn of 2002, U.S. policy-makers indicated they were looking to Japan and Germany as examples, even models, of successful military occupations. In October of that year, Secretary of State Colin Powell told the Associated Press "the United States is considering a model for Iraq that resembles Japan after World War II." Earlier, David Sanger and Eric Schmitt of the New York Times reported an occupation plan for Iraq would be modeled on the post-war occupation of Japan, with General Tommy Franks of U.S. Central Command (CENTCOM) heading up a U.S. military government in Baghdad. Franks, they wrote, would assume the role MacArthur served in Japan after its surrender in 1945. (Jennings, 2003: 15-16) Though Powell later backed off his comparisons of a post-war Iraq with post-World War II, both Franks and, later, retired General Jay Garner were chosen to head an interim government that would constitute the largest occupation force in nearly 60 years.

The comparisons made sense. During the last century, the United States has replaced 18 regimes, but democratic rule has prevailed in only Germany, Japan, Italy, Panama, and Grenada-a success rate of less than $30 \%$. It was logical for modern-day planners to look at the most successful of these ventures when preparing for the next occupation effort. Noah Feldman, a New York University law professor who served as an advisor during the drafting of the Iraqi constitution, remembers those going with him on a military plane to Baghdad were deeply immersed in the latest books on the German and Japanese occupations. Unfortunately, none of them were studying Iraq or the Middle East (Galbraith, 
2006: 97), and, despite their studies, it does not seem the post-World War II examples had a direct impact on occupation planners (Maulucci, 2008: 121).

Analysts have pointed to a number of erroneous decisions that greatly complicated the occupation's chances for success. Most of them took place within the first 12 months. (Maulucci: 123) Assumptions made by the civilian leadership in the Defense Department largely explain the inadequate force levels. Once serious contingency planning for an invasion of Iraq started in 2001, Secretary of Defense Donald Rumsfeld and Deputy Secretary Paul Wolfowitz argued for as small an invasion force as possible-somewhere around 125,000 troops. This fit their concept for a new, lean, mean, American military relying heavily on high technology, not manpower. (Galbraith, 113) For years, the U.S. military had fretted about "mission creep". Top commanders worried once U.S. forces were committed to a situation, the tasks assigned to them would continually expand from security to providing a variety of services, to standing up a government, until they were mired in what was derogated as "nationbuilding". Many in the military had listened with relief as George W. Bush denounced this tendency during the 2000 presidential election campaign, saying it was not a proper use of the armed forces. (Ricks, 2009: 293) He then went on to invade Iraq and launch perhaps the most expansive and costly nation-building effort in the history of the United States. ${ }^{1}$

It has been the fate of the West's great powers to become involved in the power politics of the Middle East, and since the Suez Crisis of 1956, it has been America's turn to the take the lead. To make the case for war, administration officials tended to look at worst-case scenarios for weapons of mass destruction, dismissing contrary evidence. At the same time, the administration's consideration of postwar issues took a leap of faith in the opposite direction, emphasizing best-case scenarios. In order to make this case, more pessimistic views had to be rejected and ignored, even if they came from area

\footnotetext{
${ }^{1}$ By 2011, $\$ 60.45$ billion had been spent in Iraq. The U.S. spent less than $\$ 35$ billion in today's dollars in Germany and even less in Japan from 1945 to 1952. (facethefacts.org, A Project of George Washington University, January $18,2013)$
} 
experts. (Ricks, 2007: 58-59) CENTCOM would spend over a year figuring out how to take down a reeling, hollow regime, but give almost no serious thought as to how to replace it. Almost all energy was placed on the easier of the two tasks, with serious repercussions. The central task of creating a politically legitimate government was inhibited from the start by the unexpected collapse of the Iraqi state and the daunting challenge of reconciling to minority status a Sunni Arab community that had dominated Iraqi politics for decades. (Id: 33)

The official Bush administration line would later become no one really foresaw the difficulties in post-war Iraq. This research will show the opposite was true: Numerous experts and policy advisors were aware of the difficulties, but their voices were either unheard or ignored. One four-star general even asserted the disinclination to listen to the doubters would go on to help create the insurgency. By refusing to consider worst-case scenarios, the Pentagon's civilian leadership did not develop answers to questions about how to conduct an occupation or rebuild a country. (Id: 99) As this work will show, the answers to these questions were readily available through the 1945 examples of Germany and Japanspecifically, the importance of civil affairs training and a delicate approach to political and economic purges. For the first time, a three-country comparison will be undertaken across a range of previously identified factors, and new factors for consideration are introduced that have not been previously identified by scholars when researching the likelihood of successful democratic transitions. The focus is on Iraq, with more detailed accounts provided in its regard to ensure the reader understands the steps and processes used by occupation forces in 2003-04. As is often the case in life, failure requires more explanation than success.

Though some degree of opposition was unavoidable, the virulent insurgency that emerged was not inevitable; rather, it was, in fact, aided by political and military blunders in Washington. From the beginning, U.S. strategy was hampered by what critics across the political spectrum agreed were several interrelated errors: an insistence on providing only a small invasion force, lack of planning for a post- 
Baathist Iraq, not considering the consequences of regime collapse on the state, and not anticipating an extended occupation or insurgent resistance. By failing to prepare for post-combat burdens and undertaking the war with minimal forces, the Bush administration compounded the problem by disbanding Iraq's military and security forces, putting more than 300,000 armed men on the streets. (Record, 2007: 79-80) Though these steps were also taken in Germany and Japan in mid-1945, occupation officials quickly adapted to situations on the ground, and altered policy accordingly. This level of flexibility was not seen in Baghdad.

During the early occupation periods in both Germany and Japan, steps were taken to purge the government of undesirables and demilitarize the countries. In these cases, concerns were raised about the lack of troops to occupy the territories and the inexperience of civil affairs officers tasked with rebuilding society, but the effects were quite different than those seen in Iraq. The U.S. encountered extreme difficulties attempting to transform Iraq into a democracy and the nation devolved into chaos within a year, compared with Germany and Japan, whose transformations have stood the test of time despite near-insurmountable obstacles in the beginning. This research explores why the two efforts produced such vastly different results and analyzes whether the same decisions implemented in different ways could have resulted in a significantly different outcome for Iraq. This is accomplished through a cross-comparison of factors in Germany, Japan, and Iraq during the first twelve months of each nation's occupation. In the case of Germany, only the U.S. zone is examined, unless stated otherwise, due to the relative lack of authority the U.S. occupation forces had over the other Allied zones.

This research will examine the relationship between contextual factors-those factors that existed prior to the occupation (and, in these cases, even before the onset of hostilities); instigated factors - those decisions and policies wholly implemented by occupation leadership; and hybrid factors - those factors which were out of the occupation's relative control, but that could have been 
dealt with prior to invasion ${ }^{2}$. Additionally, this research will argue that while the contextual and hybrid factors analyzed in this work are those conditions most cited by previous scholars as determinative of democratic success, it is the instigated factors that are truly the most dispositive. The instigated factors in this work have never been previously identified and comparatively analyzed in order to determine a "best practices" approach to post-conflict occupations.

The contextual and hybrid factors identified in this work are often put forth as the reason for the failed attempt to re-build Iraq; this research will show these factors were surmounted 60 years prior in either Germany or Japan, or both, and therefore further explanation is needed to justify the failure. The focus will be on decisions implemented by occupying forces (largely, the United States ${ }^{3}$ ) during the first 12 months of each occupation, based on the theory the first few months are the most critical in regards to establishing legitimacy and obtaining buy-in from the local population. To explain the varying outcomes of these occupations, prior references to the reconstruction of Iraq in relation to Germany and Japan tend to focus on elements of differentiation: preconditions, economic indicators, status of the state's apparatus following the invasion, levels of economic and social development, etc.; or, in the alternative, emphasize one aspect of the operation. When these dissimilarities are presented, however, they are often done so by comparing Iraq to Germany, or Iraq to Japan, not by comparing Iraq to both Germany AND Japan. Upon closer examination, it appears conditions believed to cause problems in Iraq but not Germany were, in fact, present in Japan; the reverse is also true. In each case, the occupiers overcame them. One example of this is the issue of timing: Due to the length of the Second World War, American planners had the time to work on occupation policies for Germany for two to three years and consider all possible contingencies, whereas the earlier-than-anticipated surrender of Japan left U.S.

\footnotetext{
${ }^{2}$ The author is aware, and it should be noted, that even contextual and hybrid factors, at some point in each nation's history, were instigated by the relevant actors, whether they be national leaders, the general population, or external forces.

${ }^{3}$ See note 2 , above.
} 
forces under-manned and unprepared to occupy the country. In both cases-extensive planning and not-the U.S. managed to implement successful reconstruction programs.

In Iraq (it is popularly believed), planners had but a few months and failed to accurately predict the collapse of the Iraqi state and the subsequent rise of violence. In truth, however, plans on the best way to institute regime change in Iraq had been underway since the late-1990s. Numerous think-tanks produced reports pertaining to troop level requirements and possible contingencies. (See Dobbins, et al, 2003) Military planners began preparing for the fall of Saddam as early as 1998, drafting extensive contingency plans for such an occurrence. ${ }^{4}$ But in the fall of 2002, officials in the Bush administration chose, instead, to "start from scratch". In fact, when a senior military advisor was asked about earlier efforts, he was not aware such plans existed. (Ricks, 2007: 85-87) The decision to develop a new plan mere months before the invasion does not mean the administration did not have time to plan; it simply means they did not take the time to plan well. Other inconsistencies in the comparisons arise in regards to historical factors, such as the assertion Germany and Japan had strong democratic backgrounds, while Iraq had no such experience with democracy. Such determinations have been made by comparing different periods of the respective nation's past, rather than examining the same time frame, relative to the conflict, for each country. This error is corrected here.

Though comparisons of Iraq to post-World War II have been numerous, the focus has always been on comparisons with only one former Axis power, not both. This research seeks to fill this gap. Comparisons will be made of the three categories of factors within each country at issue during the same time frame relative to the conflict: the first twelve months of the occupation, followed by a fiveyear, post-conflict status check in the final chapter. By closely examining the contextual (Category 1 ) and hybrid (Category 2) factors and determining their similarities across all three cases, it is possible to more

\footnotetext{
${ }^{4}$ These plans became known as Operation: DESERT CROSSING, and are discussed in greater detail throughout this research.
} 
definitively state the strong effect the instigated (Category 3 ) factors had in each nation. Following this process will allow for a more accurate comparison of each category's effects across cases than has previously been undertaken. Additionally, the instigated factors identified in this research have never been compared across cases before, though many notations have been made about them in single cases by observers on the ground, in the moment of their occurrence. While these observations are relied upon and cited, this work is the first major attempt to cross-analyze these factors in depth. Finally, the examination of the effect of the last instigated factor discussed in this work: the timing of elections and constitutional drafting is a new contribution to the field. Little is written (relatively speaking) about the process in Germany and Japan and occupation staffers in Iraq made only direct observations, with no comparisons to previous efforts. This research is the first comprehensive analysis of this factor to be undertaken.

When historians seek to explain the course of politics and war at key decision points, they often resort to some version of path dependence: the idea events move in a causal chain not easily reversible. In 2003, political scientists asserted "the lessons we can draw from the [post-World War II] occupation all become warnings where Iraq is concerned" (Dower, 2005: 182). Prior to the invasion, a top Bush administration official asked a leading expert on the Middle East how the United States should conduct itself in post-war Iraq. The response was two-fold: 1) Don't dissolve the army and 2) Don't purge the entire Baath party from government. (Diamond, 2005: 280-81) The first two major policy decisions the U.S. occupation government implemented did the exact opposite. Thus, the very first steps the United States took made it difficult to bring democracy to Iraq, illustrating the mistakes most crucial were made in the first few weeks. This research will seek to determine whether, at that point, the U.S. was doomed to follow a path to failure, or whether-by learning from the lessons of the past-they could have more quickly changed or reversed course so as to not be faced with "one damn thing after another" (Diamond: 281). 


\section{CHAPTER 2 \\ LITERATURE REVIEW}

"The only purpose for which power can be rightfully exercised over any member of a civilized community, against his will, is to prevent harm to others. His own good, either physical or moral, is not sufficient warrant."

- John Stuart Mill, 1859

Did U.S. policy actually cause and contribute to the levels of insurgent and militia activity in Iraq, or was a successful transition to democracy doomed from the start because of pre-existing factors? Comparisons to the U.S.'s last major experience as an occupying force were quickly made. Secretary of Defense Donald Rumsfeld even stated "turning our backs on post-war Iraq would be the modern-day equivalent of handing post-war Germany back to the Nazis" (Maulucci, 2008: 120).

The most important lesson from the U.S.'s post-World War II occupations of Germany and Japan is that military force can, at least in some circumstances, be successfully employed to underpin democratic and societal transformations. U.S. and other Allied officials successfully oversaw local and national elections and the establishment of constitutions and new governing bodies. While U.S. efforts were obviously important in these outcomes, the German and Japanese populations played a critical role. The U.S. had anticipated and planned to deal with significant residual resistance following the surrender of these countries, but no resistance of consequence emerged in either case. The presence of a large number of American troops, plus the establishment of local constabularies, preempted it.

(Dobbins, et al, 2003: 21)

\section{Nation-Building}

The existing literature on nation-building is essentially focused on failed states in the wake of civil wars and subsequent peace-building and reconstruction led by international organizations or an intervening state. The literature looks less at the result of military intervention or "hot war" between 
two nation-states ending with an occupation and reconstruction emphasizing democratization. (Bridoux, 2011: 6-7; Serafino, et al, 2006), though there are some interesting lessons to be learned from scenarios in history where a commander or viceroy is confronted with a defeated people and/or army. Upon the collapse and defeat of the Ottoman Empire post-World War I, the United Kingdom controlled, and was entrenched in, Iraq. In 1921, at the Cairo Conference, it was decided in the Treaty of Alliance that Britain would build, train, and equip an Iraqi army to protect its new monarchy. Since the army was trained in the British fashion, this caused animosity between British troops and Iraqi soldiers. 82 years later, the situation was remarkably the same, with American troops in place of the British. (Weiler, 2009: 11)

Nation-building has been defined as a "preventative political option to avoid the break-up of the state and social fragmentation, as an alternative to military conflict management, as part of military interventions, or as an element of post-conflict policies" (Hippler, 2005: 4) "Reconstruction" refers to the immediate, post-conflict phase that sees the implementation of actions aimed at restoring damaged societies to their pre-conflict conditions. "Development" unfolds on the longer run and involves the creation of new institutions and the promotion of sustained economic growth. Defeated countries often need significant financial transfers to quickly provide humanitarian assistance after the conflict and cover basic government expenditures. Reparations immediately after the end of the conflict are counter-productive; the economy must grow before a country can compensate the victims. Also, permitting more than one power to determine economic policy can significantly delay economic recovery. (Fukuyama, 2006: 5)

To date, no effort at forced democratization has taken less than five years. Many factors influence the ease or difficulty of democratic nation-building: prior democratic experience, level of economic development, and national homogeneity and cohesion. These factors are included in the contextual and hybrid sections of this work. However, among the controllable factors, the most important determinant seems to be the level of effort-measured in time, manpower, and money-the 
occupier puts into the project. There appears to be an inverse correlation between the size of the stabilization force and the level of risk: the higher the proportion of occupying troops, the lower the number of casualties suffered and inflicted. Indeed, most adequately manned post-conflict operations suffered no causalities whatsoever. (Dobbins, et al: xxiv-xxv). But other than number of troops and personnel, little research has been conducted into the effects implementation of decisions and policies have on an occupation. These factors, covered in the instigated factors section of this work, have never previously been analyzed in depth.

In Germany, a constabulary force was specifically created to respond to incidents of civil unrest, conduct mounted and dismounted police patrols, interdict smuggling operations, and aid in intelligence gathering. This contrasts starkly with nation-building efforts in such countries as Bosnia, which were marred by organized crime and civil unrest. (Id: 21) Overall, the U.S. approach to nation-building from the bottom-up in Germany, using centralized control but de-centralized execution, worked exceptionally well. Using the Germans to conduct the rebuilding while under military supervision allowed reconstruction in the U.S. zone to progress far more rapidly than in other areas. (Keifer, 2009: 17-18; See also Ziemke, 1975)

In Japan, nation-building was successful despite the absence of a long democratic history and the existence of authoritarian rule. It is believed the speed and relative ease of the Japanese transformation had two primary causes: the U.S. decision to co-opt Japanese institutions rather than rebuild them from scratch and the unilateral nature of the process. U.S. personnel were lacking in both language and technical abilities, leading MacArthur and his staff to retain the existing Japanese government and simply give the occupation officials a supervisory role. In the case of Japan, the occupation was managed through a fully-articulated Japanese government. This starkly contrasts with Germany, where most institutions were abolished and rebuilt from the ground up. Thus, both courses of 
action are available for examination and analysis as part of this research. (Dobbins, et al: 53; Bridoux, 2011; Bellin, 2004-05: 600)

Insurgency

Insurgency is the natural result of powerful human dynamics that shape the relationship between those who govern and those who are governed. Ask most experts what causes insurgency and you hear terms like "complex" and "unique". This uncertainty regarding the root of the problem itself leads to disagreement in forming the proper response. An inability to define the problem causes great difficulty in crafting its solution. According to Robert Jones' work for the Small Wars Journal, it is far more important for governments to understand an insurgency than it is to define it. This understanding then facilitates the development of effective policy and operational designs. (Jones, 2011: 1)

According to a U.S. Army Field Manual, FM 3-24, insurgency is perhaps best understood if it is taken out of the context of warfare; instead, it should be viewed as both its own form of conflict and as a condition within the population. This perspective allows counterinsurgency (COIN) movements to define the conflict in regards to its causes, rather than on how it manifests, allowing the focus of COIN operations to shift from a reactive stance to one of a more proactive nature. In essence, a conflict should be defined as an insurgency only if the root causes of the violence support such an assertion, not simply because of the tactics used by its members. Taken in this light, the most effective COIN takes place long before any conflict occurs. The development of conditions necessary for an insurgency to erupt start with perceptions of bad governance by certain segments of the population. The insurgency is then merely a mix of violent and non-violent acts as part of illegal political challenges to the existing government. Therefore, the primary cause of population radicalization is typically the government itself. (FM 3-24; Jones: 2-3; Maulucci, 2008: 122) 
Every insurgency faces three basic challenges as it begins: arming, financing, and recruiting. A peculiarity of the war in Iraq is the Iraqi insurgency appears to have had little difficulty in any of these areas. In the first area, arms, the unusual situation in Iraq actually favored the enemy. It was a land awash in weaponry and explosives, both in small collections distributed by Saddam's government before the U.S. invasion and in huge dumps-some of them the size of small cities. Policy decisions made at the Pentagon aided the insurgents because there were insufficient troops to secure the large weapons caches, let alone find the smaller ones; in fact, there were no guards whatsoever in most places. (Ricks, 2007: 191;)

In regards to finance and recruitment, finding new members is usually the most difficult task for insurgent causes, but the U.S. policies of de-Baathification and army disbandment created a class of disenfranchised, threatened leaders and tens of thousands of angry, unemployed soldiers to fill rankand-file slots. The most obvious argument against dissolving the Iraqi military was the unemployment of 400,000 Iraqi service members. It was clear to most research organizations what would happen in a highly militarized society once the regime fell if the army was not employed. According to Colonel Paul Hughes, who worked on strategy issues for the occupation, "When we disbanded the army, we created a significant part of the Iraqi insurgency." Putting people well-trained to kill on the streets with no jobs or compensation certainly risks giving them "nothing to lose" and the potential for waves of violent crimes and an insurgency becomes very real. Even the Iraqi manual on guerilla warfare taught the best place to recruit for an insurgent force is from a defeated army. Additionally, because of low occupation troop numbers, Iraq's borders were left open for nearly a year, allowing foreign fighters to enter at will. (Id; Gott and Brooke: 116; Weiler: 10) Demilitarization steps were also taken in Germany and Japan, but later reversed when the policies caused too many obstacles to reconstruction. Yet the U.S. pursued them relentlessly in Iraq. 
Particularly in post-war reconstruction, it is critical to find a common ground between various actors in order to achieve consistency of action and efficient implementation of reconstruction programs. The sooner an occupier can stop having to coerce the populace and convince them to consent to being government, the greater the potential for success. (Bridoux: $86-87,90$ ) In order to properly deal with an insurgency, a government should separate the reasonable grievances of the people from the agenda and ideologies of extremist segments of the society. Creating a physical separation between the insurgents and the government is rarely effective. Different segments of a populace often react, according to their unique perspectives, very differently to the same conditions. As a government implements programs and policies, potential causes of insurgency radiate through the population. The most critical perceptions of the population seem to be legitimacy (the right of the government to govern), justice (how the rule of law is applied), respect and dignity (how a particular segment of society is treated), and hope that grievances can be effectively addressed. (Foster: 2005)

Since modern COIN theory is heavily rooted in efforts to maintain colonies or contain an ideological threat, government relations with this imbalance of power and purpose are inherently dysfunctional. Hundreds of years of Western colonialism and 65 years of Cold War containment have shaped a powerful bias in counterinsurgency theory and doctrine. For example, most Western nations express moral repulsion and horror at the terror-bombing of civilians, then explain such an action is particular to Islamic fundamentalists who do not value human life. But "terror bombing" has been used by historians to describe the U.S. bombing campaign against Japan (Dower, 2003: 5-6), so there is nothing uniquely cultural or religious about it. Rather, it seems even democratic nations can justify such action by claiming it saves more lives than it costs, or that it was the only way to achieve their goal. Others may say the distinction is between a "legal" war and an "illegal" one-two recognized nations rather than rebellion against one's own government. But many extremists would likely view their cause as highly legitimate and worthy of such sacrifice-even more so than alleged "legal" wars over land and 
resources, since they are often fighting for immortal souls. Just as "the customer is always right", good governance is always assessed from the view of the distinct population groups that make up every society. While the option of military intervention must always be a viable reality, leading with policy and diplomacy should provide the best results at the lowest cost. The use of military power will be inefficient when the threat is unconventional, transnational, and non-state-specific. (Halper and Clark, 2004: 4)

The American ignorance of long-held counterinsurgency tactics impeded U.S. efforts in Iraq during 2003 and 2004. It is not clear why U.S. commanders appeared ignorant of how other counterinsurgencies were conducted successfully, though one theory is repugnance. Since the fall of Saigon, the military has not liked to dwell on unconventional operations. Scholars are virtually unanimous in their judgement that conventional forces often lose unconventional wars because they lack a conceptual understanding of what and why they are fighting. (Ricks, 2007: 225, 250, 253, 265) Understanding and respecting the traditional ways a culture grants legitimacy helps to avoid well-intended errors, for even high-quality engagements at the local level cannot undo flawed political strategies at the national level (Record, 2007: 81). By identifying Iraq as central to its war on terror-in fact, as its main battlefield-the U.S. legitimized the jihadist fight and pinpointed a location where foreign fighters could converge. In immediate post-conflict conditions, insecure citizens often turn to nationalist, ethnic, and other identity-based parties to protect their interests, and the more moderate parties tend to get squeezed out (Diamond: 79). The Bush administration erred by conflating both Sunni insurgents and al Qaeda terrorists into one group to be dealt with in the same manner. Al Qaeda saw Iraq as the frontline in their holy war against the U.S., while disenfranchised Sunnis simply wanted to regain their power and position. (Bridoux: 100) 


\section{Previous Analyses}

Following World War II, extensive studies were undertaken to determine the effectiveness of various military and transitional operations in both the European and Pacific theaters. In general, both theaters produced similar recommendations for future strategic plans. First, the lessons of World War II strongly support forming an organization capable of clear and effective decision-making to provide unity of command in post-conflict operations. This approach would strengthen civilian control and provide closer integration of military operations with foreign and domestic policy and favors a high degree of coordination and planning. Such unity of command, however, could decentralize administrative burdens and permit specialization. Importantly, the post-World War II studies noted there was a lack of strategic intelligence prior to the surrender of Germany and Japan: further and more accurate information was needed on the German and Japanese economies and there was no mechanism for coordination between the military, other governmental organizations, and private enterprise. Overall war plans, insofar as they were based on faulty intelligence and misinterpretation of accurate information, were unrealistic. The reports went on to note if a comparable lack of intelligence should exist at the start of a future national emergency it could prove disastrous. This realization seems to contradict popularly-held beliefs the post-World War II occupations were well thought-out and well-reasoned. (See United States Strategic Bombing Survey Summary Report: European War, September 30, 1945; United States Strategic Bombing Survey Summary Report: Pacific War, July 1, 1946) Finally, these studies concluded no greater or more dangerous mistake could be made than to assume the same policies and practices that won the recent war would be sufficient to win the next one. The results achieved in 1945 were not to be treated as answers, but rather as signposts pointing the way towards answers.

Often in military operations, planning teams divide the tasks into four phases: preparation, shaping, combat operations, and stability and support (or post-combat). Military planners for the postcombat phase of Operation: IRAQI FREEDOM assumed the coalition would be greeted as liberators and 
the Iraqi army would be available to assist in reconstruction efforts. In the weeks leading up to and following the war, the Bush administration depicted a liberated Iraq welcoming our invading troops, quickly stabilizing the political order, regaining economic vitality, and making the momentous transition to freedom - a transition that would, in turn, set off pressures for democratic change throughout the Middle East. But when the war ended, Iraq fell into a quagmire of chaos. During the period of occupation rule, the country became increasingly unstable, serving as justification for neighboring regimes that their cultures were not suited or politically ready for democracy. (Diamond, 2005: 279) Various mediums have since been saturated with opinions Phase IV of the Iraq campaign was poorly planned. Although this assertion may be valid, the problems encountered during the early phase of the occupation seem to have been exacerbated by the occupation authorities. The Coalition Provisional Authority (CPA) was formed to lead Iraq from post-war turmoil to a liberated and democratic future. The presidentially-appointed head of the CPA, Ambassador L. Paul Bremer, III, issued 100 official orders during his 14 months in Iraq. The first and second of these removed senior Baathists from government and disbanded the military. Armed with after-action reports and historical lessons from the post-World War II occupations, including problems associated with de-Nazification, the CPA still elected to push through with the de-Baathification program. Consequently, from May 23, 2003 to September 6, 2006, the security of Iraq was the sole responsibility of the United States government. (Bremer and McConnell, 2006: 38) The negative ramifications of these actions were apparent to most foreign policy and military experts, and neither were a part of the original Phase IV plan (Weiler: 2).

Most experts agree agencies and the military occupation forces backing them up should be proportionate to the extent of territory and the size of the population to be governed. In particular, the occupation forces must be strong enough to impose law and order without delay. Agencies must, as a matter of urgency, revive and direct indigenous administrative structures and work closely with their personnel. (Barnett, 2005: 16-17; Dobbins, et al., 2003; Ricks, 2009; Bridoux, 2011) In Iraq, the 
disappearance of basic governance and the CPA's failure to fill the gap led to an outbreak of rioting and violence during the first week of the occupation. At local levels, opposition groups moved to fill the vacuum, while exile parties maneuvered their way into national politics in Baghdad. The CPA was created to help stabilize the situation, but soon those excluded from power rebelled, creating an increasing climate of violence, stunted economic growth, and growing political opposition. (Marr, 2012: 257-58)

The CPA and other government advisors recognized that when there is no rule of law, no party structure to build on, and no separation of powers, near-term fulfillment of the significant responsibilities of transitional occupation would be possible only if large numbers of Iraqis could be utilized. In regards to Iraq, experts recommended forming advisory bodies not affiliated with the past regime as soon as possible to institute constitutional reform and democratic initiatives. Next, it was suggested supervised elections at the local and regional levels take place. (Jennings, 2003: 34) In early 2003, when the Iraq war was already underway, Larry Diamond, a political scientist who would become a democratic governance advisor for the CPA, noted that,

\begin{abstract}
"Iraq could gradually develop into a democracy, but the task is huge and the odds are long against it. Only a sober reflection on the lessons of post-conflict reconstruction can make a democratic transformation possible. It will require a prolonged and internationalized engagement, costing billions of dollars over a number of years. We must not repeat the mistakes of our post-war engagement with Afghanistan, which has been ad hoc, haphazard, inadequately funded, tardy in reconstruction, and utterly unwilling to deploy and utilize the military force necessary to secure the new political order."
\end{abstract}

(Diamond: 19)

Indignation over occupation and dominance by the West was not a new phenomenon, but summed up decades-even centuries-of old wounds. According to New York Times correspondent John F. Burns, "Steeped in the history of the early Caliphs, Iraqis know that Baghdad 1,000 years ago was a center of learning and military prowess. Since the modern state's founding in 1921, they have been under the boot of colonial rulers, imposed kings, or brutish dictators." Because CPA personnel and the 
Bush administration never grasped this history, they could not anticipate how vehemently much of Iraq would oppose an extended occupation.

Ideally, the military should use its expertise to establish security, open aid corridors, facilitate logistics, and supply civilian implementers with information on potential dangers. It should use its engineering and civil affairs experience to enable the distribution of humanitarian aid and reconstruction only to the extent international and local civilian agencies are unable to do the job. But emphasis on civilian organizations will work only if they are sufficiently funded and fully informed about the operational environment, which never happened in Iraq. (Id: 301)

Over the past few decades, scholars have built an extensive body of knowledge and research on the conditions that foster stable democracies. In its early form, this literature emphasized the need for economic development: democracy was more likely to emerge and stabilize where there was reasonable prosperity, limited inequality, a strong middle class, high levels of literacy and education, a productive market economy, and a vigorous civil society. The level of a country's economic development proved to be one of the best predictors of durable democracy. In more recent years, however, the pattern began to change somewhat. Beginning in 1974, a new wave of democratic expansion began to sweep the world and the proportion of the world's democratic states climbed dramatically, from a little over one-quarter to nearly $60 \%$ by 1994 . Many of these nations did not have the classic "conditions for democracy", making predictions of successful transitions even more difficult. (Diamond: 19-20)

In the case of Iraq, it was not simply the level of economic development and the structure of its society that gave many experts pause; it was also the trajectory of the country's subjugation and decline over the past half-century. Although Iraq had a tradition of liberal thought, the nation was coming out of a long period of brutal dictatorship, its economy and society were devastated by 45 years of authoritarian rule, and Saddam Hussein had plunged his people into two wars. These conditions drove millions of Iraqis into exile and decimated the middle class. (Id) 
"Preconditions" refer to factors influencing the setting in which post-conflict occupations take place. According to most scholars, preconditions to the occupations of Germany and Japan generally played in favor of the U.S. reconstruction. In contrast, it is believed preconditions to the occupation of Iraq and the inability of the U.S. to deal with the issues they later caused constituted a severe blow to the effective implementation of reconstruction policies.

While enjoying high levels of domestic approval at home, foreign policy tenets and the process leading to the 2003 war with Iraq caused a decrease in the U.S.'s international legitimacy, resulting in a lack of international support for the occupation. Moreover, the regional opposition of Arab populations to the invasion, the perception of the U.S. as a destabilizing force, and the gap between planning and reality all threatened the consistency of American actions and its effective exercise of power. Most research asserts that because of its inability to deal with the negative effects of these preconditions, the Bush administration jeopardized the outcome of the Iraq reconstruction from the start. (Bridoux: 18990) This research explores whether this belief is correct: were the preconditions cited by earlier scholars, or what this research will refer to as contextual factors and hybrid factors, truly more in the U.S.'s favor in Germany and Japan? Or was it wholly the fault of the U.S.'s own strategy and policy choicesinstigated factors - that the Iraq reconstruction failed? It is the first attempt to control for the first two categories by conducting a three-country comparison and is the first comprehensive comparison of the latter category of factors that-it is theorized-have a far more significant impact on occupation efforts. According to Eva Bellin, Germany and Japan began with a set of endowments-many of them anticipated by democratic theory, but others peculiar to the countries' unique historical context and time-favoring democratic outcomes. Bellin did not find these endowments replicated in Iraq, and does not believe a military occupation would guarantee success in such a situation. Historical experience suggests a military occupation may increase the likelihood of democratization and wise policy choices certainly improve its chances; however, the outcome is largely shaped by factors-both domestic and 
international-uncontrollable by military engineers operating within unfamiliar cultural norms and conventional limits of time and treasure. (Bellin, 2004-05: 595)

Historians John Dower and Charles Maier have spoken on the topic of Iraq's reconstruction, emphasizing there is "no viable comparison" between the period following Japan's defeat and the period following Saddam's downfall. Dower believes the successful occupation and eventual reconstruction of post-war Japan were due to significant conditions not present in Iraq, such as Legitimacy of Occupation, Consistency, Cohesion, Security, Civil Institutions, Exhaustion, External Enemies, and Economic Conditions. (Dower and Maier, 2005) Bridoux largely concurs with his assessment (Bridoux: 129, 163). As noted above, however, these works do not then analyze whether these preconditions were present to the same extent in Germany. The contextual and hybrid factors being used in this research are asserted by numerous scholars to have positively affected either Germany or Japan while negatively affecting Iraq. Historical Precedent, Societal Cohesion, Exhaustion, and External Enemies are placed in the Contextual (Category 1) Factors, because these factors were largely out of the occupier's control at the time conflict began and ended. Economic Development, Legitimacy, Consistency, Security, and Civil Institutions fall into the Hybrid (Category 2) Factors due to the limited, but greater, control occupation forces had over them at both the time conflict ceased and during the occupation.

\section{Category 1: Contextual Factors}

Historical precedence. The cases of Germany and Japan suggest an indigenous "authoritarian” culture, or perhaps a misinformed perception of it, is not an insurmountable obstacle to implanting democracy. Scholars argue both Germany and Japan had experience with democratic rule prior to World War II, but the Weimar Republic's and the Taisho version of democracy were both seriously flawed-to the point some have even called them "nonexistent" (Bridoux: 9). The post-Versailles Weimar Republic 
had a parliamentary government with active political parties, but it was a volatile form of government because of a number of radical splinter groups on the political left and right. Significant elements of German society did not fully embrace the enlightenment traditions of personal liberty and selfgovernment. (Dobbins, et al.: 6) In Iraq, most political parties were replaced by cliques of religious or ethnic elites while Saddam ruled through fear and nepotism (Bellin, 2004: 600). Still, Iraq had a constitutional democracy as early as the 1920 s, and many political parties maintained their status underground or lived in exile through 2003.

With democracy so firmly established in Japan and Germany today, we tend to forget that in the post-war period, the conventional wisdom was both societies were culturally inhospitable to democracy. In fact, Germany was the focus of numerous studies aimed at pinning down the nature of the "authoritarian personality" purportedly endemic to German society. Japanese society was considered too "conformist" and "herd-like" to provide fertile ground for democracy. The cultural descriptions of these countries sound much like what is leveled at the Islamic world today. (Bellin, 2004: 606-07) The lesson for Iraq: political institutions do not have to be indigenous to be acceptable. So long as the innovations are perceived as serving key interests and do not come at the expense of national identity, institutions of foreign derivation might be expected to survive.

Societal cohesion. While politically diverse, Japan was socially cohesive, without Iraq's apparent religious, ethnic, and cultural conflicts. There were no hostile political or religious factions within Japan. (Dower, 2005: 3) Similarly, post-World War II Germany had a much higher degree of political, ethnic, and cultural unity than Iraq (Maulucci: 122). Both Japan and Germany enjoyed significant consensus about their national identity and could count on a fair degree of social solidarity within their societies. (Bellin, 2005: 598) The same is not said of Iraq. According to Bellin, specific factors worked against the success of Iraq's reconstruction, including its religious and ethnic cleavages, which Saddam took every opportunity to deepen (2004: 4). A sense of Iraqi identity exists, but it is a common-held belief the 
nation is deeply divided between Sunni, Shia, and Kurds. However, though these groups partly define their identities in reference to various ethnic groups, faiths, and tribal backgrounds, Saddam's regime broke these affiliations and atomized Iraqi society, linking "each individual vertically to the patron state" (Al Khajafi, 2003: 79). It was not until later that he fell back on using tribal leaders, rather than government actors, to curry favor. Therefore, the identity definition and social fragmentation of the various groups composing Iraq is not as clear cut as some believe (Bridoux: 9-10), as evidenced by strong resistance to deep federalism in the new constitution (See Diamond, 2005 and Marr, 2012). Finally, it should be noted Germany had been a nation for less than 70 years when Nazism began to take hold and many of Japan's prefectures were actually conquered ${ }^{5}$ nations, not original Japanese territory; to this day, many of those citizens do not consider themselves native Japanese.

Exhaustion. In 2004, a year after the fall of Saddam, "everyday [in Iraq] seem[ed] to be a day of grief and mourning. If you compare the situation[s]...the contrast is stunning. For eight or nine years...the Japanese were grieving and mourning, but not about what was taking place in front of them." Instead, their grief was based on the death and destruction caused by nearly 15 years of war, whose termination, even if it meant defeat, they were eager to embrace. Japan was at war from 1931 to 1945. 54 cities had been bombed, leaving 3 million dead and 10-15 million people homeless. There was rampant unemployment, malnutrition, and disease. Tokyo was reduced to rubble. Defeat brought "liberation from death" - the air raids stopped and the people could start over. As Dower notes, this was a psychological relief. (Dower, 2004)

The Germans, like the Japanese, were weary of war and welcomed the chance to build a new society. Both nations suffered the firebombing of many cities and were facing the specter of starvation. Seven million Germans died in the war, there was an appalling refugee crisis, and the economy

\footnotetext{
${ }^{5}$ Okinawa, for example, and the Ryuku islands in the north, are current-day Japanese prefectures who have their own cultural backgrounds.
} 
collapsed. (Id; Bellin, 2004: 601-602) But while Iraq did not have as many internal causalities, such assertions, again, seem to underestimate the terror with which Saddam ruled. One need only to visit the killing fields scattered throughout the Shia heartland in the south, or speak to the Kurds in the north about the regime's chemical attacks, to get a much clearer picture of how Iraqi society likely greeted the chance for a new start.

External Enemies. The United States used the threat of communism to persuade the Japanese government to support an extended occupation. This same threat was even more effective on the Germans. Today, even after the end of the Cold War, 40,000 troops remained stationed in Japan, as well as their families and support personnel, with a substantially larger American military presence in Germany. As attention shifted to Europe in 1945, and the Iron Curtain forming there, Japan dropped out of the public eye, giving its reformers some breathing room. (Dower, 2005; Maulucci: 122) Iraq, however, is located in a volatile region of the world with potential enemies on all sides. Its violent history with Iran and Kuwait, not to mention potential issues with Syria, Saudi Arabia, and Israel, left it without likely support from its own neighbors and vulnerable to outside influence on internal politics. Since the U.S. was not able to secure the nation internally, the Iraqis had little hope the occupation force could prevent serious external threats, particularly subversive ones.

\section{Category 2: Hybrid Factors}

Economic development. Prior to the outbreak of World War II, both Germany and Japan were great powers-highly industrialized countries with developed economies boasting impressive GDP per capita. Though the war devastated much of the physical capital in both countries, Japan and Germany retained the human, organizational, and social capital (skilled workers, managers, and social networks) to serve as the core of economic development. (Bellin, 2004: 596) Maier compared Germany and Japan to a firm whose building burned down and simply needed an infusion of capital to get started again, 
whereas Iraq was like a firm putting a business together for the first time. "And, as we know, 70 percent of all new businesses fail." (Maier, 2004). However, in Iraq, extensive damage to the oil sector, transportation, and electric power infrastructure was avoided during the conflict and invasion (Dobbins, et al., 2003: 181). It was not until later insurgent attacks and rioting began to damage these structures. Most of the technocrats who knew how to manage and maintain Iraq's facilities remained in the country, but the CPA's de-Baathification order removed them from office. (Ricks, 2007: 159) “Brain drain" was not the problem before or during the war, nor was infrastructure.

Japan's economy was actually crushed during the war, with economic sabotage also taking a toll. The economy was plagued with hyperinflation until 1949 and only the black market showed any sign of vitality (Dower, Maier, and Bellin), but liberal economic policies inspired by the New Deal gave the Japanese government a larger role in the economy. De-militarization also led to thousands of workers now focused in a non-military direction: "aircraft builders constructed rapid railways, battleship builders made super-tankers, tank builders made construction equipment, and electronics experts worked with Sony". The reforms introduced were actually quite stunning, and amounted to a sweeping commitment to nation-building. The Americans introduced major land reform, essentially taking land from rich landlords, eliminating widespread tenancy, and creating a class of small, rural, landowners. New labor laws guaranteed the right to organize, bargain collectively, and strike. (Dower, 2005) This "sweeping privatization" was not planned for in Iraq, however. Many similar ideas were stated as goals for Iraq, but the CPA did not push reforms through with such a heavy hand. Instead, they tried to rely on a relatively large group of Iraqis to reach and implement the same decisions in a timely fashion. By then, it was too late.

Economic take-off and prosperity need not be immediate to ensure public endorsement of political change. Conventional wisdom teaches the surest way to persuade people to embrace political reform is to "deliver the economic goods". People associate the new institutions with prosperity and 
endorse them. What is striking about the German and Japanese occupations is just how long it took for the economy to pick up in both countries: three to five years for these nations to really prosper. By comparison, Iraq was ahead of schedule at the one-year, post-conflict point; Germany and Japan were still relying on imported rations and living on reduced-calorie diets twelve months into their occupations. (Bellin, 2004) Iraq's oil industry also reached pre-war output levels before early 2004 (Banerjee, 2004).

The lesson of Germany and Japan seems to be that military occupation can provide added value by rectifying state institutions, kick-starting economic development, and structuring political and economic incentives in ways that make elites lean towards democracy. In neither case was democracy a foregone conclusion; extended intervention with democratic intent was necessary.

Legitimacy of Occupation. The post-World War II occupations possessed a great intangible quality not perceived to exist in the U.S. war with Iraq: virtually unquestionable legitimacy, not merely in the eyes of the victor, but in the eyes of the occupied citizens and those of U.S. allies, as well. A formal war was followed by a decisive defeat and unconditional surrender. In Iraq, the U.S. found its actions widely challenged within Iraq, throughout the Middle East, and much of the rest of the world. (Maier and Dower; Dower, 2003: 3) After their defeat, Germany and Japan had little choice left but to accept the occupation and the reconstruction projects defined by their victors. In Iraq, the U.S. toppled a regime but did not defeat a country. (Bridoux: 127-28; Maulucci: 122) As Bremer underlines, "the vast majority of Iraqis were surprised to find a foreign, non-Muslim army occupying their country" (Bremer: 37). Defeated or liberated populations are often more docile, cooperative, and malleable. In contrast, many Iraqis - ruling-class Sunnis, particularly-never felt defeated. And, as members of the ruling class, they were not "liberated". In the eyes of most Iraqis, the war was merely to depose Saddam, not punish their society. (Ricks, 2007: 142) 
Consistency of Authority. Throughout the war, Japan had an intact government: Emperor Hirohito declared war, surrendered, and continued as head of state until 1971 (Dower and Maier). Except for the military, the Japanese government remained intact at all levels, as did the German civil bureaucracy, and civil order was maintained in both nations (Dower, Maier and Bellin, 2004). In Iraq, no leader emerged as a unifying force (Bellin, 2004). U.S. officials were victims of the speed at which they disposed of Saddam's regime because no additional troops joined the invasion force to deal with the sudden collapse of law and order (Feith, 2003: 24) and subsequent de-Baathification orders effectively ceased all government operations. Compounding this is the fact the U.S. replaced its first interim government in Iraq - the Office for Reconstruction and Humanitarian Assistance, under Jay Garnerwith the CPA, under Bremer, within the first month of the occupation.

Security. The hardships Germany and Japan faced after the war were staggering, but there was no terror; during this horrible time, both societies remained relatively stable and secure. The fact Japan was an island meant there was little fear of terrorists or foreign fighters coming across the borders, and though Germany was faced with the threat of the Red Army almost immediately upon its surrender to the Allies, this only served to enhance its security as the remaining allies rallied to prevent its fall to the Soviets (Maulucci: 122). In neither Germany nor Japan was there armed resistance, assassinations, or reprisals against collaborators, nor were there any centers of terrorism in neighboring states (Bellin, 2004). There were virtually no incidents of violence. In Iraq, a shortage of troops left the extensive borders largely open, allowing foreign fighters, jihadists, and other types of insurgents to travel freely into and out of the country (Weiler: 7, 12, 26; Ricks, 2007).

Ironically, the swiftness with which the United States toppled Saddam's regime and the avoidance of civilian casualties may have actually worked against the success of reconstruction. In Germany and Japan, the experience of total defeat and devastation broke down old conventions and opened the people to new ideas. The much shorter war in Iraq, with relatively little loss of life on the 
part of the civilian population, did not produce significant psychological impact, while the sanctions imposed on Iraq after its invasion of Kuwait in 1990 probably increased resistance. According to Bellin, "the hardships under the sanctions were like a slow bleed, rather than a sudden, mortal shock, and a slow bleed often makes people more able to cope." Also, in the absence of television, the Internet, email, and other forms of electronic communication, American authorities were able to maintain strict control over the sources of information in Germany and Japan in a way not possible in Iraq. (Dower, 2005; Dower, Maier, and Bellin, 2004)

Again, however, previous works seem to overestimate the conditions Iraqis lived in for more than a decade and underestimate the terror Saddam's regime instilled throughout society. Iraq's political, social, and economic structure badly eroded under Saddam, and the occupation brought it to levels of unprecedented political and social collapse, to the point that by 2006 , Iraq was almost a failed state. It was the coalition's lack of understanding of Iraq, lack of substantial international support, and lack of clear planning that made the decision to occupy the nation fraught with danger, not resistance from the population. Toppling Saddam was easy and swift, but replacing the government and the political and social institutions underpinning the regime was a long, difficult, and costly process - for both the United States and Iraq. The initial violence-made before the CPA even came to volitioncreated widespread destruction and a political and social vacuum, which foreign personnel proved unable to fill. Iraq soon began to fracture into ethnic and sectarian components. (Marr: 257)

Civil Institutions. According to Dower, Japan had a "deep tradition of democracy and civil society" and the structures essential for reform were still in place at the war's end. (Dower, 2005) Germany also had a tradition of liberal, democratic government on which to build. Bellin asserts this was a major difference from Iraq, whose governmental and civil institutions were destroyed and who had neither an effective, meritoriously organized bureaucratic system nor a recent tradition of democratic government (Bellin, 2004). Experts also argue Japan and Germany had effective police forces, a working 
judiciary, and a civil service with which to govern. Germany, after all, had been the paradigmatic bureaucratic state, and the Nazi regime ruled through it (Belllin, 2004: 599). Under Saddam, Iraq was sorely lacking in effective state institutions, was patrimonially organized, corrupt, and driven by politics and loyalty tests rather than merit. (Id; Dower, 2005) This research will serve to illustrate, however, that conditions on the ground in Germany and Japan were not as effective or efficient as is commonly believed; in fact, neither the judiciary nor constabulary was functioning when the occupation began, a fact well-documented by Army and other War Department reports. For example, the "police" in Germany were often everyday citizens armed only with sticks.

$\underline{\text { Instigated Factors }}$

Bellin asserts that although military occupation cannot fashion democracy out of whole cloth, it can steer countries in a democratic direction through wise policy choices. In this research, instigated factors also influenced the setting in which the occupation and invasion took place, but the occupation forces had significantly more, if not absolute, control over them: for example, the process chosen to achieve objectives and the quality of planning for post-war reconstruction. These are also factors that have received significantly less attention in previous scholarship, other than anecdotal work by actual participants in the operation. The instigated factors examined in this research are: Operational Planning, Approach to Civil Affairs, Governmental Policies, and the process for Elections \& Constitutional Drafting.

Operational Planning. Many assert the U.S. encountered economic, political, cultural, and social conditions in Iraq having very little in common with post-World War II reconstruction efforts. However, besides different reasons for going to war than those used for Germany and Japan (repelling aggression versus preventative strike), the context and purpose of the Iraq reconstruction was not so different in its essence. In all three cases, America set clear goals: demilitarization and democratization. It was the steps taken to reach these goals that varied. Much emphasis is placed on the level of commitment on 
the part of the occupiers to seeing their project through, particularly in regards to Iraq. The American occupation of Japan lasted more than six years and involved the deployment of more than one million Americans. Comparable investment was made in Germany. (Bellin, 2004: 602). Though the U.S. was rhetorically committed to democratization in Iraq, there was a much smaller commitment made, both at the beginning and during the so-called "surge" of 2007-08. Additionally, the U.S. planned only a 14month duration for the Iraqi operation-they would leave in time for the spring 2004 troop rotation (Bremer, 2006). This was despite the fact the occupations of both Germany and Japan were initially planned to last only six months, rather than six years. It appears the U.S. either chose to ignore these historical lessons, or extremely over-estimated what they had learned from them in regards to transforming a nation.

In August 2002, a National Security Presidential Directive (NSPD) entitled "Iraq: Goals, Objectives, and Strategy" laid out post-war aims in highly generalized terms: "to establish a broad-based democratic government...that would respect the basic rights of all Iraqis" (Woodward, 2004: 154-56). When it came to the means of implementing these objectives, the directive merely referred to the efforts of the "Iraqi opposition" to Saddam, meaning outcast politicians (Barnett: 6). In other words, administration officials hoped the local citizenry would eagerly step in and begin running the country, including development of democratic law.

Overall, the lack of preparation by occupation officials reached unprecedented proportions (Maulucci: 126). Many asserted the Allies had much more time to prepare for occupation during World War II (See Maulucci; Dower, 2005; Bremer; Bellin, 2004; and Dobbins, et al.) By starting to plan in 1942, Allied officials had the time to work on occupation policies for two to three years before the end of the war and to consider all possible contingencies (Bridoux: 127-28). But despite popular belief the administration had inadequate time to prepare for the occupation of Iraq, U.S. Central Command (CENTCOM) had planned the invasion of Iraq and the removal of Saddam's regime for years. Operations 
Plan (OPLAN) 1003 was written as a directed contingency plan in 1991, but had not been updated since 1998. Since this plan was based on DESERT STORM-era thinking, CENTCOM spent months revising it, resulting in OPLAN 1003V in August 2002. Of note, this plan included an estimated need for 250,000 troops and asserted it would be necessary to establish a new Iraqi army, create a constabulary, and implement well-designed and well-funded reconstruction projects (Keifer: 20). However, the initial U.S. occupation force had less than 150,000 soldiers and Marines.

Regardless of the time factor, U.S. officials managed to produce a rather comprehensive plan with clear objectives, but they failed to accurately assess the extent of the Iraqi state's collapse and the subsequent rise of violence. Also, while there was a sound knowledge of the German and Japanese political, economic, and cultural aspects among the staff of the occupation authorities, that data was lacking for Iraq's occupiers because Saddam had shut out U.S. interests for most of his rule. (Bridoux: 128) Instead, U.S. planners chose to rely on information provided by exiled Iraqi politicians, though many had not lived in the country for decades.

Approach to Civil Affairs. A report by the RAND Corporation during the summer of 2003 asserted Iraq had geographic neighbors that might interfere in the reconstruction process, but democratic nation-building would be possible if the U.S. committed sufficient personnel and financial resources. The report noted "the highest levels of casualties has occurred in the operations with the lowest troop levels." (Dobbins, et al.: 153) As noted above, most experts recommended at least 250,000 troops would be needed to successfully occupy Iraq (See Keifer; Dobbins, et al.; Ricks, 2007; Bremer, 2006). But the limited size of the new U.S. military did not allow for a sustained, long-term, massive force occupation (Maulucci: 124), and some senior leaders even argued increased troop presence would make tensions worse (Desch, 2007: 105). In the end, Iraq was invaded with less than $60 \%$ of the recommended troops, and most of the soldiers who were expected to maintain law and order had no training in constabulary work or civil affairs. 
Governmental Policies. U.S. officials in Iraq could have most-benefited from the lessons of deNazification during Germany's occupation. Despite removing all Nazi party officials from their positions in German government, U.S. officials would eventually rehabilitate more than $90 \%$ of those purged (Jennings: 15). General Lucius Clay, the commander in charge of the occupation of Germany in 1945, quickly discovered former Nazis were effective at governing and the best-equipped to administer the infrastructure. Additionally, being a Nazi was a matter of economic benefit and employment, not necessarily a sign of personal ideology. This was also the scenario with Baathists in Iraq. Being a Nazi did not mean you were of the same mind as Hitler, and being a member of the Baath party did not automatically mean you subscribed to Saddam Hussein's agenda (Weiler: 12-13).

In Japan, the occupation government also purged well-known militarists and wartime collaborators. Vetting these individuals proved more challenging without the "Nazi party litmus test", to the point that local citizens, under the supervision of American military officials, stepped in to help. The role of the Japanese government was important, though nominally so, as General MacArthur used them to deliver messages or as consultants. (Jennings: 17-18) Largely for technical and language barrier reasons, large portions of the Japanese government remained intact to implement policies and decisions of the occupier. This allowed the citizenry to keep some sense of national pride, an element necessary to motivate them to embrace the task ahead (Bridoux: 135). This starkly contrasted with Germany, where most institutions were abolished and then rebuilt from scratch. Therefore, the U.S. successfully utilized both methods-re-establishment and integration-and had historical lessons-learned from both approaches available in Iraq. Yet, even armed with after-action reports and extensive studies, the CPA still elected to ostracize the people responsible for managing the infrastructure and securing the nation. In Iraq, de-Baathification resulted in a government purge that provoked the former ruling-class Sunnis to fall back on their common identity as a form of protection, which translated into a reinforcement of the insurgency-the exact opposite effect of the program's intent. Rather than repenting, those punished 
for being Baathist rejected the occupation. (Bridoux: 169) Consequentially, the security of Iraq was the sole responsibility of the United States government for many years (Bremer and McConnell: 38).

Elections and Constitutional Drafting. The decision to hold national elections in Iraq first, rather than local referendums, actually postponed the return of sovereignty and delayed a constitutional convention. This decision was contrary to the steps taken in post-World War II efforts. Timing of elections is historically the least explored factor examined in this work, and it is hoped this research will highlight its importance to long-term democratic efforts.

One of the last questions decided in planning for the occupation of Iraq was who would lead the effort. Retired Lieutenant General Jay Garner was appointed by the Defense Department to oversee the occupation only eight weeks before the invasion concluded. Before he even arrived in Iraq, however, President Bush was taking steps to replace Garner's staff with the more structured and long-term CPA. Garner's appointment was confusing given that, according to Secretary Rumsfeld, the U.S. military did not engage in nation-building; such issues were foreign policy concerns. In fact, it would be a senior diplomat, Bremer, who would replace the retired military officer as head of the occupation.

The political "pass the buck" between the Department of Defense (DoD) and the State Department, with each agency jockeying for power while trying to reduce accountability, would continue throughout the occupation (Ricks, 2007: 80-81, 101-109, 154-55; See, also, Bremer and McConnell, 2006). In Germany and Japan, one agency oversaw the U.S. presence, allowing for a unified policy on the ground, despite bureaucratic infighting in Washington. Things in Iraq became even more complicated when members of the ad hoc Iraqi Governing Council (IGC) were included. Going into the spring of 2004, not Washington, Bremer, or the IGC seemed to have a clear plan as to how the country should be governed, and the ideas each proposed often conflicted with one another.

President Truman began the occupations of Germany and Japan with very little pre-conceived notions as to how they should proceed-America had never been in this position before. President 
Bush, however, seemed to be highly involved in the day-to-day events in Iraq, as did several members of his senior staff. Rather than aiding the process, their involvement only served to slow things down and led to disagreement as to the best way to proceed. Truman's eventual approach was a bottom-up effort, beginning with grassroots initiatives at small, local offices. Bush decided to implement national elections first so as to establish a governing body capable of taking over as the sovereign authority. But reaching this point took three different elections for transitional bodies before Iraqis reluctantly agreed on their new leadership. (See Bremer; Ricks; and Marr)

\section{Summary}

Though much debate has taken place about what went wrong in Iraq, historians and analysts tend to agree most of America's failed policy decisions took place within the first 12 months, and the worst errors came in the first few weeks (Maulucci: 123). If early policy decisions can have such a momentous impact-even more than a decade later-it seems to dispel the belief that on-the-ground conditions before the occupation were more important; instead, this points to the argument that it is the occupier's ability to properly assess the conditions that will lead to success or failure. Rather than tackling the roots of the violence in Iraq, early U.S. responses relied essentially on uses of force to combat-rather than prevent-insurgent behavior.

In Iraq, like in Germany and Japan, the United States aimed at bolstering its global position of power by physically occupying and ideologically formatting a country to be a faithful ally in a region strategic to American interests (Bridoux: 162). This research, unlike other works before it, will compare each category of factors explained above and determine if, in fact, they are dissimilar when comparing Iraq to Germany and Japan. The presence of the contextual and hybrid factors in either Germany or Japan will show the U.S. has surmounted such challenges in the past and weakens the reliance on these factors as explanation for failure to transform Iraq. If Iraq is more similar to Germany and Japan than is 
popularly believed, then an examination of the instigated factors becomes necessary, a step that to this point has been given only cursory examination in most works, and never from a three-part, comparative approach. Therefore, this work is the first contribution to the field attempting to control for the first two categories of factors to the greatest extent possible, while also doing a qualitative comparison of the effects of instigated factors within all three nations. This is also the first time a strong analysis is accomplished on election timing and the drafting of a new national constitution, post-conflict. 


\section{CHAPTER 3}

\section{CONTEXTUAL FACTORS: GERMANY, JAPAN \& IRAQ}

This chapter will focus on Contextual (Category 1) Factors. These factors have been examined by many scholars previously, either individually or in a two-country comparison, but the label and category assignation are unique to this research. For each of these factors, occupation forces had little-to-almost no control of the situation, as these factors were developed as the occupied nation evolved over time. Most of the already-existing research concludes these factors were present in Germany and/or Japan to a positive extent, but not in Iraq, and are the major reasons the occupation results varied. However, as discussed and analyzed below, a deeper look shows this is not the case; in fact, occupation officials should hope not, since such a truth would lend a near-predetermined status to any occupation effort.

\section{Historical Precedent with Democracy}

Nation-building is not principally about economic reconstruction; rather, it is about political transformation. The spread of democracy in Latin America, Asia, and parts of Africa suggest this form of government is not unique to Western culture or to advanced industrial economies. Democracy can, in fact, take root in circumstances where neither exists. (Dobbins, et al, 2003: xix)

\section{Germany and Japan}

Germany had some experience with democracy in the years prior to World War II, as the postVersailles Weimar Republic was a parliamentary government with active political parties. It was a volatile form of government, however, because there were a number of radical splinter parties on the political right and left, and significant elements of German society did not fully embrace the enlightenment traditions of personal liberty and self-government. Instead, Germans focused on the inner development of the individual and the unique cultural exploration of the German nation. (Craig, 
1982: 32-34) Furthermore, the economic crisis in the interwar years, which was marked by high unemployment and rampant inflation, strengthened the extremist parties and wiped out a large portion of the German middle class.

At the time of occupation, many U.S. policymakers and occupation planners were skeptical the Germans had the necessary cultural background and psychological disposition for flourishing democracies (Serafino, et al, 2006). The Allied commands in Germany faced the problems of re-starting the German economy after its collapse in early 1945, repairing war damage, and providing housing and employment opportunities for the influx of German refugees from the east. (Dobbins, et al: 6) It was unknown how the Germans would react to a democratic form of government imposed on them following years of harsh dictatorship, but the German peoples' transition to free government was inarguably a success. Today, Germany is a stable, peaceful, and prosperous democracy that does not threaten its neighbors. In fact, Germany is listed by the IMF, the CIA Factbook, and the World Bank as the third largest economy in the world based on GDP. The skeptics of 1945 were proven wrong.

Japan, in principle, had a constitutional form of government throughout World War II that was still in operation at the time of occupation in 1945. Like Germany, Japan had developed consequential party structures, a critical press, and familiarity with competitive elections (Bellin, 2004-05: 600). The Taisho democracy was seriously flawed, however. Freedoms necessary to sustain a democracyfreedom of speech and assembly-were severely curtailed, to the extent they existed at all (Dobbins, et al: 27-28). The concerns many Americans had about the Germans not being culturally disposed to democracy carried over to the Japanese. Economic concerns also existed in both countries, with neither having a significant middle class or strong civil society. But Japan was able to overcome its past, and by 1950 reached its pre-war economic status. It is now one of the most peace-preserving nations of the world, with the second-largest GDP on the planet (IMF, CIA Factbook). 
Iraq

In building a democracy, Iraq would not be starting from scratch. As political scientist Adeed Dawisha showed, the country saw a robust, if partial, emergence of democratic institutions-and even liberal beliefs-during the first four decades of the modern Iraqi state. A constituent assembly wrote the first constitution for Iraq in 1923-24 (Diamond, 2005: 320), establishing a representative monarchy, but it was overthrown in the military coup of 1958. The consolidation of Baath Party rule began in the 1960s, and by the mid-1970s the officer corps was rapidly being Baathized. In 1978, a decree made any nonBaathist political activity in the military punishable by death, though other civilian political groups were still permissible. As second-in-command of the Baath Party, Saddam Hussein cultivated a network of kin and clan relations, often cutting across party lines, allowing him to bypass military and party structures to expand his personal control over these organizations. (Id: 143; Marr, 2012: 149-50) He became president in 1979 in the first peaceful transition of power Iraq had seen in more than two decades.

(Marr: 175) In 1980, a new law provided for a 250-member assembly to be elected by secret ballot every four years. All Iraqis over the age of 18 were eligible to vote, and the country was divided into electoral zones of about 250,000 inhabitants each. ${ }^{6}$ Elections were routinely held, but were not competitive and largely for show. (Id: 178)

Many have argued though Iraq had a brief experience with competitive elections in the 1920 s and '30s, this was largely an elite charade. They point to the fact that, since 1958, Iraqis have known only rule by force (See Tripp, 2000). However, these same attitudes and beliefs were frequently expressed in regards to Germany and Japan: both were seen as militaristic and autocratic at the end of the war, and both had experienced years of terror and oppression without a true democratic government in place. Each had only lived with democratic elections for about 15 years before powerful

\footnotetext{
${ }^{6}$ There is no indication the U.S. ever attempted to use these zones or electoral roles as a starting point for implementing new, democratic elections in Iraq.
} 
regimes began to consolidate their power. Others have asserted there were no political parties to resurrect in Iraq in the spring of 2003 (See Bellin, 2004-05); however, this is incorrect. Several exiled parties eagerly returned to Iraq following the fall of the regime, and several internal ones quickly emerged. In fact, there were more groups willing to lead Iraq than were willing to try for power in Germany and Japan. ${ }^{7}$ (See Ziemke, 1975; Bremer, 2006; Diamond, 2005)

\section{Summary}

Germany, Japan, and Iraq each suffered through authoritarian and militaristic regimes. Their experience with true democracy was close to non-existent. At the time of their occupations, the United States faced regimented people and strong conservative elites. In all three countries, the governments were drained by costly wars that left the infrastructure in a state of disrepair and the population with a desire for change. Each was offered an opportunity by being placed at the center of a project aimed towards creating a new regional and world order. (Bridoux, 2011: 9) When asked in February of 2004 what type of government they wanted, $86 \%$ of Iraqis said "democratic". One official with the Coalition Provisional Authority commented on the high numbers of Iraqis who were willing to fight to the death at the coalition's side to defend the idea of a democratic future for their country. (Diamond: 244,314 ) But, unlike Germany and Japan, Iraq never saw its efforts bear fruit.

\section{$\underline{\text { Societal Cohesion }}$}

\section{Germany and Japan}

Post-World War II, Germany and Japan were both free from much of the corrosive ethnic and regional factionalism that impaired the peace process in Iraq. (Jennings: 29) Both had apparently

\footnotetext{
${ }^{7}$ The political parties and other groups present in post-2003 Iraq are the subject of a chapter in Part II of this research.
} 
homogenous societies (Dobbins, et al: 195) and neither was marked by ethnic or religious fractures, or vulnerable to post-war destabilization from ethnic or religious minorities. Postwar borders were relatively sound, and there was no equivalent to tribalism in either instance threatening to break the nations apart. Each country harbored a strong sense of national unity, which in turn contributed to maintenance of stability. In Japan, social structures were preserved and the nation had been ethnically homogenous and politically stable since the centralization of the Meiji Constitution in 1890 (Junichiro, 1983; Beasley, 1990: 76). The absence of readily apparent fault lines running across German and Japanese societies played in favor of the occupation. (Bridoux: 164)

Looking deeper at the demographics and population statistics, however, reveals the German and Japanese societies were not nearly as cohesive in 1945 as is popularly believed. Germany's U.S. zone now included millions of ethnic Poles, Czechs, and other Western Europeans, most of whom were brought to the country by force. It was also forces to assume responsibility for millions of ethnic Germans expelled from other nations, though these individuals were not actually German citizens. (Zeimke, 1975) The Nazi regime had spent close to a decade "Aryanizing" the country, with the result being large groups of Jews, gypsies, and other segments of society being considered "cast-offs", even "sub-human". Most of the nation had acquiesced to-if not supported-Hitler and his aims, leading to the oppression, intimidation, and outright murder of an enormous number of fellow Germans.

Japan's treatment of its minority groups actually led to the development of the term hisabetsu buraku, or "discriminated communities", also known as the burakumin. Discrimination against these groups arose through Buddhist and Shinto beliefs opposing "pollution" (most of the burakumin worked in occupations considered "unclean", such as butchers). Throughout the Meiji period, burakumin were treated as social outcasts, with even some casual interactions considered taboo. Although physicially indistinguishable from other Japanese, they often lived in ghettos, and their identity was surmised by 
their dialect or mannerisms. Background checks designed to uncover burakumin as part of the employment process were legal in some parts of Japan until 1985. (Masahisa, 1998)

Other ethnic minorities in Japan include the Ryukyuans and the Ainu, both of which were isolated on the perimeter islands of the nation and neither was considered ethnically Japanese (Shinichiro, 1960). In fact, some of these islands had hoped to receive sovereignty after the Allied victory, showing they clearly were not on the side of their own nation. Bringing these groups together in a time of near-famine was no small feat, yet peaceful elections were held within a year.

Iraq

Frequently, the kind of post-war reconstruction initiated by the international community comes with conditions based on western liberal ideologies. This approach often denies existing resources, such as indigenous knowledge, grassroots movements, and cultural traditions and ignores the capacity and strength within local communities that can often be collaborative and healing. (Papavassiliou, 2017) In 2003, the common belief was Iraqi society did not benefit from the same degree of solidarity and homogeneity as its World War II counterparts. Similar to Bosnia and Kosovo, there is no consensus on the nature of the Iraqi nation: it has a fractured polity, with sectarian and ethnic divides, a mixture of groups defining their identities less in regard to an Iraqi nation and more in line with cultural backgrounds. (Bridoux: 164) The plurality of Iraqi identity is complex, and has repeatedly been misused to incite political violence. But the role of societal cohesion does not rely solely on "feel-good" events; it can be linked to a shared bloody history, such as that which has shaped Iraq through modern times (Papavassiliou, 2017).

The state of Iraq is a new, $20^{\text {th }}$ century creation, brought into being by politicians and statesmen. As a nation-state, modern-day Iraq was not formed until 1920, when it was carved from three former provinces of the Ottoman Empire and created under British mandate. Its borders are largely artificial, 
reflecting the interests of the Great Powers following World War I, rather than the wishes of the local population. (Marr: 4-9) The British spent several decades forging an Iraqi state out of the remains of the empire, but neither they nor their Iraqi successors were able to make a real Iraqi nation. Britain installed an array of state institutions to govern Iraq: a monarchy to head the central government and symbolize Iraq's unity, an army and bureaucracy to keep order and run the country, and a Western-style constitution providing for indirect elections and a parliament (Id: 21). However, politics in Iraq has often been more authoritarian rule and the settlement of disputes by force. The investiture of a Sunni king established a pattern of sectarian politics that burdened Iraq for decades. The exercise of power by the minority Sunnis over the majority Shia produced great instability: 58 separate governments ruled Iraq in the 37 years between 1921 and the 1958 revolution that overthrew the monarchy. (Bowen, 2009: 2)

Although a sense of Iraqi national identity does exist, the general belief is it does not override communal forms along the ethnic, geographic, tribal, or religious lines. The majority of the populationKurds and Shia-have no real tradition of representation in national politics. (Dobbins, et al: xxvi) Iraq also has a number of non-Muslim minorities that predate Islam. Additionally, the historical importance of tribes in Iraq cannot be exaggerated. The settled village community with its attachment to the landthe backbone of the social structure through much of the Middle East-has been a missing link in Iraq's social fabric. Instead of love of the land, loyalty to family and tribe has dominated Iraq's social and political life. Among the legacies of tribalism in Iraq are intense concerns with family, clan, and tribe; devotion to personal honor; factionalism; and, above all, difficulty cooperating across kinship lines, the underlying basis of modern civil society. The result is familial and tribal ties taking precedence over national loyalties and broader ideologies within the political realm. (Marr: 18-20)

Following the Baath party's seizure of power in 1968, however, the regime efficiently used extreme violence and powers of patronage to co-opt or undermine any independent vestiges of civil society (Dodge, 2003: 106; Tripp, 2007: 26). Thus, while Sunni, Shias, and Kurds partly define their 
identities in reference to various ethnic groups, faiths, and tribal backgrounds, Saddam's regime-in order to survive-broke those affiliations and literally atomized the Iraqi society, "linking each individual vertically to the patron-state" (Al Khajafi, 2003: 79).

At the time of occupation, Iraq was nearly $80 \%$ Arab and $97 \%$ Muslim; thus, both the Sunnis and Shias share similar cultural attributes. Behind the power struggles in modern Iraq lie two sectarian groups with a common history, the divisions between them primarily political rather than ethnic or cultural, reflecting the competition of the two groups over the right to rule and define the meaning of nationalism in the country. (Nakash, 2003) Even the Kurds-the majority of whom are Sunni Muslimsshare a similar religious background, if not ethnicity, with close to $100 \%$ of the country (Van Bruinessen, 2013). Because of this, the identity definition of the various groups composing Iraq is not as clear-cutor as non-reliant on a national identity-as some believe. Despite their status as non-elites, the Iraqi Shias demonstrated their national loyalty during the eight-year Iran-Iraq War, when they successfully and consistently fought their fellow Shia of Iran (Ghabra, 1997).

Iraqis in exile who fled in the late-1990s tell of a lessening ideological climate, as well as an alienation from the Baathist extremism that caused the nation so much destruction. Even former members of the party express an eagerness to embrace change and begin rebuilding the country. (Id) As soon as the occupation began, Iraqis and Kurds express a desire for people to be brought together, rather than deepening societal divides. The Baath party had often been an obstacle to communities working together; now, there was a desire to collaborate. (Isakhan, 2011) During discussions about the shape of the new Iraqi government, the concept of federalism - rather than a break-up of the politywas quite prominent. Iraq has always been highly centralized and, for many Iraqis, a unitary state is a bedrock principle of their nationalist identity. In fact, they view a possible division along ethnic lines as a plot to weaken or even dismember the country. (Diamond, 2005: 163) It would seem Iraqis recognize the traditional concept of a nation-state, and are aware of the power it holds on the international scene. 
Their unwillingness to divide the country along cultural borders illustrates a realization they are stronger together, in spite of their differences.

Building a cohesive nation despite a country's longstanding internal grievances is not an unusual task. There are many examples of inclusive states all over the world, from Latin American to Eastern Europe, most of which avoided Yugoslavia's route of conflict. South Africa illustrates power-sharing and the ending of racism; post-Civil War United States; Welsh and Scottish acceptance of the English; even Switzerland are still more situations where factionalized groups still shared a common identity. In fact, a negative past can be a motivating force of its own, to bring about positive changes-Middle East Quarterly noted the German and Japanese examples, specifically, when discussing this fact. (Ghabra) It must also be noted that at the time of invasion in 2003 , Iraq had been a recognized state ten years longer than Germany at the end of World War II and the United States at the time of the Civil War. Its borders had been stable for nearly a century, it did not lose vast amounts of territory in a subsequent peace treaty, and it did not have to assimilate vast hordes of non-Iraqi citizens. Germany, itself, was brought together from remnants of the Holy Roman Empire, and rampant debate was held over what segments of that population should be included in the new nation. This brings into stark relief the fact that, at some point, all nation-states had to "become" a country from previously un-named plots of land and cultures, and just because their boundaries may be artificial and include varying ethnic groups and religions, it does mean they do not identify themselves as one people. The impression Iraq is not a cohesive nation seems to revolve around the violence it is currently experience in comparison to Germany and Japan today-not, as this research has strived-by comparing them within the same time frame relative to the conflict.

Finally, the possibility the cohesiveness of Iraqi society is viewed through a biased, Westernized lens must be noted. Believing Iraqis would not want to form a unified nation-state even before beginning the effort (most works citing Iraq's lack of cohesion are dated prior to 2003) assumes 
knowledge of the inner thoughts and aspirations of Iraqis. Even a quick scan of this section shows those disbelieving in Iraqi cohesion have more Western sounding names, while those advocating its existence appear far more "ethnic", even Middle Eastern. Perhaps Iraq is not so much lacking in cohesion, as scholars are lacking in understanding of what it means to be cohesive in a tribal-based, Arab culture.

\section{Exhaustion}

Levels of destruction sustained by a country can also influence the outcome of reconstruction projects (Bridoux, 2011: 163), not just in terms of physical damage, but in regards to the psychological state of the occupied population. A difference in psychological states is asserted by some as the reason the German and Japanese societies were more amenable than the Iraqis to embracing a new political project under democratic auspices (Bellin, 2004-05: 601, 602).

\section{Germany}

By the end of World War II, Germany and Japan were utterly defeated. The last years of the conflict severely damaged the Germany's physical infrastructure (Killick, 1997: 88), a huge refugee crisis loomed, the economy collapsed, and hunger haunted nearly everyone. Additionally, nearly seven million Germans died during the war (Bellin: 601). In most industrial areas, more than half the houses were damaged, while nearly two-fifths were beyond were repair. The transport system had been smashed by bombardment, with only 656 miles of rail track operable out of nearly 8,000 miles. All seven rail bridges across the Rhine were destroyed and the canal system suffered from similar damage. 1,500 road bridges were destroyed and there were desperate shortages of fuel and civilian vehicles. Essential ports were encumbered by wrecks and other obstructions; the telecommunications net was reduced to chaos. Coal was in short supply, and it served as the energy source for electric power, industry, and the remaining petrol plants. Millions of displaced persons had to be sheltered, fed, sorted out, and eventually 
repatriated to other parts of Europe, not to mention the several million German prisoners of war who needed to be disarmed and demobilized. (Barnett, 2005: 1; U.S. Bombing Survey, 1945: 1, 3)

Allied bombing of Germany's major population centers began in July 1943, and proceeded to destroy one major urban center after another. The U.S. Strategic Bombing Survey ${ }^{8}$ made extensive studies of the German people's reactions to these attacks. They discovered the morale of the German people deteriorated; most of all, they wanted the war to end. They had entered the war well-stocked with clothing and other consumer goods, and during the early years, consumption remained high. Most goods eventually became difficult to obtain, though studies show fairly adequate supplies were available until the last stages of disorganization. Even food, while strictly rationed, was nutritionally adequate throughout the war. (U.S. Bombing Survey: 14) But if the Germans had been at liberty to vote themselves out of the war, they would have done so well before the final surrender; however, they lacked either the will or the means to make their dissatisfaction evident. Examination of official records showed absenteeism increased and productivity slowed in the late stages of the war, but by and large the workers continued to work. (Id: 4)

Japan

At the end of an exhausting four-year war, Japan's empire lay in ruins. More than three million people were dead, millions more were homeless, one-quarter of the country's wealth was destroyed, and the civilian economy was near collapse. Years of total war had wrought devastation, including the firebombing of major cities and two atomic bomb attacks. As a result, the surviving population was weary of conflict and disinclined to contest defeat. (Dobbins, et al, 2003: xxii, 4, 28; Bellin: 601; Dower, 2003: 2) By the summer of 1944 , it was evident to Japanese commanders there was no way to equal the

\footnotetext{
${ }^{8}$ Following the war, the United States commissioned two large-scale surveys of the air campaigns on the European and Pacific fronts. These surveys were tasked with analyzing the effectiveness of the respective bombing campaigns and provide detailed accounts of their impacts.
} 
United States' military prowess. Japanese losses were becoming catastrophic and the results being achieved were negligible. The only asset they still possessed was the willingness of their fighters to meet certain death, thus leading to the development of the Kamikaze technique. The hope was this approach would cause more damage than the U.S. was willing to endure. 2,550 Kamikaze missions were flown between October 1944 and the end of the war, 18.6\% of which were effective. Meanwhile, the physical destruction resulting from attacks on Japanese cities approximated that suffered by Germany. In the aggregate, nearly $40 \%$ of the cities were destroyed and close to $30 \%$ of the urban population lost their homes. In order to construct firebreaks, the Japanese tore down all the houses on select streets, resulting in 615,000 homes destroyed, in addition to the 2.5 million residences hit by the air attacks. The railroad lines managed to suffer little damage, however. (Pacific Bombing Survey ${ }^{9}, 1946: 16,24,28$ )

A growing food shortage was the principle factor affecting the health and vigor of the Japanese people. Even prior to Pearl Harbor, the average daily caloric intake in Japan was only 2,000 calories, compared with 3,400 in the U.S. Japan has only $3 \%$ of the arable land of the United States to support a population more than half as large. Despite food rationing starting in 1941, the situation soon became critical. By 1945, the average daily intake was less than 1,700 calories, with most receiving less so that heavy industrial workers could have more. (Id: 28)

By July 1945, Japan's industrial potential was fatally reduced, her civilian population had lost its faith in victory and was approaching the limit of its endurance, and her leaders-convinced of the inevitability of defeat-were preparing to surrender. After 10 years of war, Japan was materially and psychologically exhausted. The ruling political class was discredited and there was no one to turn to in search of purpose and direction except the occupier. (Bridoux: 164) Thoroughly beaten, the Japanese

\footnotetext{
${ }^{9}$ Similar to the European Survey, the Pacific Bombing Survey examined Japan's overall strategic plans, internal discussions leading to the surrender, the course of the health and morale among the civilian population, and the effects of the atomic bombs.
} 
army-and more importantly, the Japanese population-simply did not have the resources to physically contest the American occupation (Id: 128-29).

Iraq

In contrast, it is largely assumed Iraq did not experience the same shock of utter defeat and crisis Germany and Japan went through. America's military victory in Iraq was irrefutable, but the war's duration was relatively short and the civilian casualties were, thankfully, limited. This lessened the sense of doom. Iraqis suffered many years of severe hardship prior to the war, including shortages of food and medical supplies, but this suffering is often described as more akin to a slow bleed than a mortal blow, allowing for the development of coping mechanisms. Thus, there was less psychological receptivity to dramatic change. (Bellin: 602) Moreover, the Coalition defeated a hated regime, not an entire country, as was the case with Germany and Japan. The result was Iraqis who were glad to be rid of Saddam but unhappy about the continued occupation of their country by non-Muslims. (Maulucci, 2008: 122)

The sanctions regime of the 1990s profoundly changed Iraq's social and economic structure for the worse. Oil production dropped 85\%; per capita income fell from \$2,000 in 1989 to $\$ 609$ by 2003. The large middle class experienced sharp declines in living standards as oil revenues plummeted. Families drew on savings in an attempt to partially preserve former levels of consumption, but skyrocketing inflation made most items unaffordable for average families. Additionally, Iraq suffered a hemorrhage of its educated and technocratic elite. Famine was only avoided by an effective rationing system. Infant mortality rose steeply, and with drugs and medical supplies lacking, the health services were nearing breakdown. (Marr, 2012: 238; Dobbins, et al: 192-93) More than 40\% of Iraqi adults were illiterate, and the population was very young, with $40 \%$ under the age of 15 . This young, burgeoning, increasingly urban population faced pervasive joblessness and disruption of services. (Diamond, 2005: 21) There was little damage by the war itself, though. At the time of America's lightening conquest in 
April-May 2003, Iraq's infrastructure-though decrepit and obsolete because of a decade of UN sanctions - was nonetheless functional. But the majority of the Iraqi bureaucrats and specialists in charge of those services all but vanished. (Barnett: 1; Bridoux: 163)

\section{Summary}

When conflicts have ended less conclusively and destructively, as in Iraq, the post-conflict security challenges are always more difficult. It seems the swifter and more bloodless the victory, the more difficult post-conflict stabilization can be. (Dobbins, et al: xxii) This has led researchers to look at the intensity of a conflict as an explanatory factor for the level of security achieved during reconstruction. In Iraq, the actual conflict was extremely short relative to the European and Pacific Wars, and human and material damages were light. In contrast, Germany and Japan were involved in a total war, exhausting themselves to the point that resistance to the new order was impossible. (Dower, 1999: 45-8) A sense of utter defeat and desperation began to pervade their societies, and this misery created a psychological crisis in both countries, breaking down old conventions and making people receptive to new ideas and approaches, especially those that seemed to be associated with hope and liberation. (Bellin: 601)

It is true, Iraq was not leveled by Allied bombings as Germany was; however, neither was the majority of Japan. And assertions regarding the level of Exhaustion in the 1945 occupations tend to gloss over the fact the armies for both nations were still fighting as the Allies invaded-they did NOT simply take off their uniforms and go home, as the Iraqis did, nor were there massive defections or large-scale mutinies. Japan's reliance on kamikaze techniques may be used to illustrate their desperation, but is also evidences the people's willingness to stay in the fight. To say Iraq suffered from a "slow bleed" versus a culture shock also seems to overlook that Japan was low on supplies and living on rations even before the attack on Pearl Harbor, nearly four years prior. Iraq's decline was not caused by active 
conflict: The United States may have been somewhat resented, but it was not a hated enemy the population spent years fighting and suddenly was forced to obey. Presented this way, it seems quite surprising the German and Japanese people accepted the Allied presence as easily as they did. By not accepting the occupation's presence, Iraqis actually hurt themselves, as living conditions in their country declined even further after the conflict.

When one remembers images of joyful Iraqis celebrating the arrival of U.S. troops with adulation, it is difficult to reconcile that image with a people unwilling to accept change and eager for a new life, as most of the above-cited scholars would say was the case. Rather, one must wonder why the occupation did not provide these new approaches based on hope and liberation, as least from the perspective of the ordinary citizen. If circumstances occurred that changed the Iraqis perception of Americans so drastically, what were they? And at what point was it early enough to prevent them? Most importantly, why did living conditions and infrastructure operability in Iraq decrease dramatically AFTER the end of the conflict, the exact opposite of what occurred in Germany and Japan? These are some of the underlying questions this research aims to examine.

\section{External Enemies}

A major factor often asserted as favoring democratic outcomes in Germany and Japan is the lack of external enemies opposing occupation forces following World War II. Going hand-in-hand with security, in 1945 efforts were able to focus on reconstruction, rather than on repelling an outside opponent. The heightening of the Cold War-Soviet expansionism in Eastern Europe and the outbreak of the Korean War in Asia-made the communist threat tangible and deepened America's commitment to establishing stable democratic allies in Germany and Japan. Central to the staying power of these American occupations was the irrevocable pairing of an idealistic commitment to spreading democracy and a realpolitik interest in containing communism. (Bellin, 2004: 601-02) In addition, isolated 
geographically and alienated from her neighbors because of her policy of racial superiority, Japan did not benefit from external support constituting a challenge to the U.S. occupation (Bridoux, 2011: 164). Obtaining materiel support from abroad would have been difficult, to say the least, because Japan's wartime atrocities were still a vivid memory (Cohen, 1987: 60; McGrath, 2006: 28)

In 2003, it was strongly recommended by outside experts the United States take unequivocal responsibility for, and control of, Iraq's borders to prevent infiltration by jihadists attempting overt or covert intervention in Iraqi affairs. (Dobbins, et al, 2003: 168, 197; Diamond, 2008: 21) Iraq is in an unstable and undemocratic region, surrounded by neighbors who were unsympathetic to democratization. ${ }^{10}$ Instead, following the fall of the regime, Iraq's borders were left largely unsecured and unprotected. An inflow of money, jihadists, and others opposed to the occupation put Arab regimes allied with the U.S. under siege as their populations questioned the intervention of a western power and the massive presence of American troops in an Arab nation. Though their numbers were initially small, many of these jihadists were seen as defending Islam against a new crusade of Western imperialism, and they quickly attracted disillusioned Iraqis to their cause. (Diamond: 8)

The lack of U.S. engagement with Iraq's neighbors-especially Syria and Iran-regarding the future of Iraq further impeded reconstruction efforts. Inconsistency between local, regional, and global policies also impacted the effectiveness of security measures. By insisting the promotion of democracy was a foreign policy objective, the U.S. effectively closed the door on Iranian or Syrian support for maintaining stability in the region. In fact, both Syria and Iran supported factions actively opposed to the occupation: Sadr's Mahdi Army and the Badr Corps of the Supreme Council for the Islamic Revolution in Iraq (SCIRI) were based in Iran prior to the war and many of the detainees held in U.S. custody were Syrian nationals. ${ }^{11}$

\footnotetext{
${ }^{10}$ At the time of Iraq's occupation in 2003, the Middle East had only two democracies, Turkey and Israel, both of which were culturally different from Iraq and distrusted by Iraqis.

${ }^{11}$ Author's personal knowledge based on her deployment in 2008 with Task Force 134: Detainee Operations.
} 
In truth, it is difficult to say Germany and Japan had no external enemies in 1945; in truth, everyone was their enemy, including the United States. They had just been defeated in the bloodiest and most destructive in world history and their occupiers did not invade to improve the lives of the Germans and Japanese. It is more apt to say there were no enemies of the occupation of these countries, for this is where the U.S. truly erred in regard to Iraq. Declaring Iraq the frontline of the global war on terror led jihadists to view it not just as a battlefield, but as a chance for exposure to promote their cause (Bridoux: 99, 107). This development was inconsistent with U.S. global foreign policy objectives of regional stability around the world, control of the conventional arms race-especially the spread of WMD-and winning the war on terror by cutting support to international terrorism. Rather, this action caused significant regional instability and led to increased funding and support of international terrorists, since the battlefield was now clearly identified. (Id: 182)

So, actually, it cannot be said that Iraq's reconstruction was a failure because it had too many external enemies; in fact, it would appear to have had too much help opposing the occupation. This is in contrast to Germany's and Japan's experience with the Soviet Union. They each knew the U.S.-imposed transition to democracy was the more attractive option as the specter of Cold War began threatening Europe. They also knew they would receive no assistance from any other nation should they choose to resist. Future efforts, therefore, should examine not just the enemies of the nation to be occupied, but potential enemies of the occupier, as well. 


\section{CHAPTER 4}

HYBRID FACTORS

Now that the factors in existence at the time conflict began in the cases under review have been examined, focus will turn to Hybrid Factors, or those factors for which occupation forces had slightly more influence (though, often effects of these factors were out-weighed by combat concerns). Hybrid (Category 2) Factors have also been previously examined by scholars at an individual or two-country scale, but never has the lack of a Hybrid factor in one 1945 occupation been explained or differentiated if it existed in the other nation. Yet, again, the majority of previous works conclude these factors were present in Germany and/or Japan, but not Iraq, and therefore played a major part in those efforts' success or failure. Since occupiers may only have limited control of a situation, even in victory, by the times hostilities cease, it is hopeful these factors are not truly dispositive, as many have asserted, and that other, more controllable factors may play a larger role. This research is the first significant efforts to investigate this theory.

\section{Economic Development}

In 1848, John Stuart Mill commented that a country could be laid waste by fire and sword, but this doesn't really matter where recovery is concerned; what matters is not so much what is destroyed, but rather what human resources survive (See Principles of Political Economy, 1848). Even though Germany and Japan were laid to ruin by the bombing of their cities, what survived for both was an exceptionally literate population whose long war efforts had, in fact, contributed to advances in technological and technocratic skills. These great human resources were available to be mobilized to new ends more peaceful and progressive than before. 


\section{Germany}

On paper, the U.S. occupying force in Germany was only supposed to organize the economy to the extent needed to "meet the needs of the occupying forces and to ensure the production and maintenance of goods and services required to prevent disease and unrest." (JCS Directive 1067; Killick, 1997: 60) However, General Clay, the military governor of the U.S. zone, ignored this directive, as did the U.S. military officers under his command who were in charge of the various German municipalities. Because the national government was, for all intents and purposes, dissolved, the military governors of the zones were not only responsible for civil and political affairs, but also for the economic recovery of their sectors. U.S. military government directed its energies towards reviving German output as quickly as possible to provide sustenance to the population, including refugees, with substantial effort devoted to restarting German factories and mines. (Dobbins, et al, 2003: 17)

A few weeks before the close of hostilities, Germany reallocated its nitrogen supply to agriculture, at the expense of ammunition. According to Production Minister Speer, this was his independent decision based on a belief the war was lost and the next year's crop should be protected. He reported to Hitler in March 1945, "the German economy is headed for inevitable collapse within 4-8 weeks". (U.S. Bombing Survey, 1945: 10) Most German industries were hit in the course of RAF city attacks, were secondary targets, or suffered spillover effects from the primary targets. These included optical plants, power plants, factories making electrical equipment, machine tool plants, and a large number of civilian industries. The attacks caused significant discomfort, as well as some diversion of resources away from essential war-making industries. The power system, except for isolated raids, was never a target, due largely to a mistaken belief the German power grid was highly developed and losses could easily be compensated. ${ }^{12}$

\footnotetext{
${ }^{12}$ In fact, Germany's power situation was precarious from the start.
} 
The German economy actually had a substantial cushion until the closing months of the war. Germany entered the war with an excellent railway system, and this was maintained throughout the war until bombing destroyed the tracks themselves. Even at the end of the war, certain German industries had inventories of steel ranging from comfortable to generous. Germany began the war with the highest standard of living in the nation's history, following several years of full employment. (Id: 11-14) When the war was over, the enemy commander became a concerned and responsible administrator. But the country's struggles were far from over. In the U.S. sector, as in others, the Russians had dismantled and hauled away $95 \%$ of the industrial machinery. What was left was buried under rubble or was useless due to lack of coal and electricity to run it and the raw materials with which to work. Except for city and suburban rail lines, which were essential to get German civilians back and forth to work, the railroads carried only U.S. troops, DPs, and military supplies. The cars ran with leaking roofs and broken windows because new glass and tar paper always disappeared on the first run. The 100,000 trucks and buses in the U.S. zone were so diminished by requisitioning less than a quarter of them were operable. Out of their wartime profits, factory owners could afford to clean up and put their plants in order, but afterwards all they could do was sit and wait for coal, electricity, and materials. The most visible part of the work force for many months were the women who scavenged usable bricks and other building materials from the rubble. (Ziemke, 1975: 347, 350-51)

Only $15 \%$ of the entire industrial establishment in the U.S. zone was in working condition by August 1945, and at only $5 \%$ of capacity. Output was meager, and every industry re-started increased the shortage of coal. The first firm to operate in the U.S. sector sharpened used razor blades. In the fall, a radio manufacturer began turning out a dozen sets a day, and several metal fabricators - on orders from the military government-began making stoves and cooking utensils out of salvaged materials. Meanwhile, the zone was supporting half a million DPs as Germans expelled from Eastern Europe flooded in. An average of 45,000 came each week in May and June 1945, and only $12 \%$ could be 
classified as fully employable. $65 \%$ needed relief and-contrary to agreements to keep families together-the countries expelling the Germans were holding back the young, able-bodied men. General Eisenhower stressed the need to help the Germans prepare for the coming winter and authorized the use of Army trucks and drivers to assist with bringing in the harvest. He acknowledged the coming months would be hard, with food and transportation shortages, no coal for heating during the winter, and houses needing repaired; however, while the Army would help, the Germans would have to solve these problems themselves by working together. (Id: 347, 350, 435)

General Clay, the U.S. viceroy in Germany, was an engineer by training and also an expert at reconstruction. His military experience consisted of assignments with the Army Corps of Engineers during the New Deal and as the Army's Chief of Materiel during World War II. He was able to use his expertise to restore public utilities, clear roads, and move rations and supplies to prevent starvation and disease. (Barnett, 2005: 13) The Army's focus on getting things moving was vital to minimizing suffering and accelerating recovery. Economic policies pursued by General Clay and U.S. Army personnel under his command were the key to economic recovery of West Germany. In the U.S. zone, General Clay and his subordinates rapidly and efficiently organized the provision of humanitarian assistance and restarted government services and economic activities. (Dobbins, et al: 22) The Joint Chiefs of Staff had set the ceiling for the German standard of living at the lowest level among neighboring nations, while Potsdam put it at the average, excluding Britain and the Soviet Union. This allowed the Germans to receive relief above the mere "prevention of disease and unrest" formula. In accordance with the Potsdam level of industry plan, it was proposed to reduce Germany's industrial capacity to 55\% of its 1938 level and cut the standard of living by $30 \%$. (Ziemke: 284 )

In the U.S. zone, 185 plants were earmarked for reparations and more were being surveyed; however, U.S. authorities knew the important thing was restoring Germany's ability to support itself, not just to punish it. To that end, in the spring, occupation officials launched an import-export program for 
the zone. To deal with pricing issues, rationing and distribution, imports and exports, and to determine essential civilian requirements, SHAEF created the Economic Control Agency. (Id: 276)

The most immediate problem was the collapse of the economy that occurred when central fiscal and monetary management was in abeyance at the start of the occupation. The occupying powers continued to allow the German central bank to operate under occupation control (Dobbins, et al, 2003: 17), but deposits exceeded withdrawals by so much the banks were in trouble-there was no place to invest. Everybody had money from high wartime wages and compensation for bomb damages. In the midst of shortages, the Germans were both rolling in money and bankrupt at the same time, since they were accountable for reparations and a 450 billion reichsmark war debt. (Ziemke: 346, 433) Except for purchases of a small and dwindling selection of rationed items, the reichsmark had no domestic value and was worthless internationally. Barter had become the norm in business transactions and nothing moved in trade except in exchange for some other commodity. The workers often found it necessary for survival to spend more time trading on the black market than working at their jobs, since a salary bought nothing but the daily ration. A staff of appointed economists had a currency reform plan ready in six weeks, but Soviet and French opposition led to a two-year delay before it was implemented. (Id: 434) Despite these challenges, German economic output recovered rapidly. By September 1945, the Transportation Corps had opened $90 \%$ of the first-line railroad tracks in the zone (Id: 350$)$. In the spring of 1946, plants and mines were reopened and industrial output had risen to 2.4 times what it was the previous year. German GDP was only $40 \%$ of its 1944 level, but economic policies quickly moved towards creating an environment favorable for business by attempting to create a free market economy. As part of this process, German cartels were broken up and resources to support the population were provided through GARIOA. (Dobbins, et al: 18)

The first published report by the Control Commission for Germany in June 1946 describes what was accomplished in the first 12 months of the occupation in regards to physical reconstruction and 
political and social transformation (HQ, Control Commission, 1946: Vol 1). During the first six months, over 500,000 dwellings received emergency repairs, internal postal services were back to normal, and the public telegraph service was carrying 50\% more traffic than in 1938. Almost the entire route-mileage of the railway was repaired and operable and 800 rail bridges were repaired or rebuilt, including two semi-permanent ones over the Rhine. About one-third of the 1,500 demolished road bridges had been reconstructed, while the number of road transport workshops increased $500 \%$. All main waterways were open and monthly inland water transports rose from 40,000 tons to nearly two million. German ports had been cleared of obstructions and were capable of dealing with the demand. (Barnett: 2,3$)$ In only a year, the German economy was back on its feet and well on the road to recovery.

Japan

Since Japan surrendered before invasion became necessary, much of the infrastructure of the country was still intact, unlike in Germany (Jennings, 2003: 25). The Strategic Bombing Survey team was able to secure the principal surviving Japanese records and interrogated top Army and navy officers, government officials, industrialists, political leaders, and many hundreds of their subordinates throughout Japan. It was thus possible to obtain reasonably accurate data on Japan's economy, plant by plant and industry by industry. (Pacific Bombing Survey, 1946: 3)

Despite impressive and intense effort in the previous decade, Japan's economy reached only $10 \%$ of the potential of the United States. Having little experience with mass production, the country had no opportunity to build up a large force of mechanically and industrially trained personnel. This meant shortages of skill, ingenuity, and ability to improvise. By the summer of 1944, Japan exhausted the possibility of forcing a greater share of their economy into direct war activities. Their plants, railroads, and mines were under-maintained to a point where breakdowns were becoming more and more serious. The residential and small commercial and industrial structures were destroyed in 
incendiary attacks. Damage to local transport facilities seriously disrupted the movement of supplies, hindering production, repair work, and dispersal operations. By the last month of the war, production of electrical power declined to $40 \%$ of peak levels and oil refining was less than $15 \%$ of 1943 output. The civilian population was underfed, receiving practically no new clothing or miscellaneous civilian supplies. People worked to the point of fatigue, resulting in rising absentee rates, and highly skilled workers were being drafted into the armed services. Roughly one-quarter of all the people in the cities fled, resulting in a mass migration of 8.5 million, but the national traditions of obedience and conformity were effective in controlling the behavior of the population. It was uniformly agreed that Japan's greatest asset was the spirit of her people-their willingness to make every personal sacrifice for the Emperor.

(Id: 20-21; 24-26, 29)

Until 1946, the initial approach to the reform of the Japanese economy was mainly punitive and aimed at maintenance of a minimal level of economic activity needed to meet basic needs of the people and reduce Japan's war potential (Dower, 1999: 529). Japan was permitted to maintain its industries, but only to the point necessary to sustain the economy and pay its war reparations. Only access to, not control of, raw materials was permitted. The dissolution of the massive economic combines was at the top of the agenda, as they were seen as in collusion with, and having benefited from, the war economy. In the initial phase, MacArthur and his staff focused on democratizing economic opportunity with the goal of providing the $80 \%$ of the population previously denied an economic stake in the nation a reason to support the new democratic status quo. A Japanese "New Deal" took shape, distributing wealth more widely, breaking up combines, purging big business, encouraging labor unions, and banning trade cartels. Members of combine-owning families were dispossessed and barred from positions in business for ten years, alongside a purge of economic leaders who had been active proponents of militarist nationalism and aggression. (Dobbins, et al: 45; Cohen, 1990: 14; Bridoux, 2011: 137) 
In addition to these microeconomic reforms, the occupation also designed a land reform program aimed at rooting democracy in rural areas by eliminating exploitative landlordism and rural tenancy, eradicating the existing social order by emancipating millions from a form of semi-serfdom. ${ }^{13}$ Local land commissions were in charge of implementing the program and it served as a first experience with democracy for Japanese farmers. (Bridoux: 137) Even today, land reform is seen as the single-most important factor for quelling rural discontent and promoting political stability in the early post-war period. (Dobbins, et al: 50)

Perhaps the most controversial aspect of the economic reform program was the purging of industry leaders. The purge was applied to those in "positions of important responsibility of influence". But fear that applying the purge too rigorously would disrupt efforts to rebuild the economy caused occupation officials to resist pressure from U.S. businessmen and the press to see it through. In the end, the economic purge affected less than 1,900 members of the business elite and had no discernible effect on industrial production. (Id: 46-47)

The consent of the Japanese population to these programs was easy to win. The dissolution of the combines, the purge of economic leaders, the de-concentration of economic power, and the opening of the economy gave more business opportunities to more people. Hunger also forced the people to accept whatever the occupiers offered. High respect for education, high literacy rates, and high levels of industrialization also eased the acceptance for the U.S. economic program. (Von Hippel, 2000: 13-18) Further consent was garnered through the promotion of trade unions and the promulgation of laws protecting workers' rights (Bridoux: 171-72).

\footnotetext{
${ }^{13}$ This step was also viewed as the best way to block Communist influence by preventing use of one of its traditional recourses: the freeing of the peasantry.
} 
Iraq

At the time of its 2003 invasion, Iraq was a sophisticated country, not a struggling developing nation on the brink of disintegration. The country's infrastructure, though already worn from neglect and damaged by war, remained serviceable. Natural resources, arable land, a sophisticated diaspora, and high education levels were all assets. The culture was predominantly secular and distinctly urban. However, after the invasion, many Iraqi technocrats and their families who were Baath Party members of convenience fled. Already strained basic utilities, transportation, and communications infrastructure became unreliable during the looting period, and the rule of law deteriorated when the security forces stopped reporting for duty. (Jennings: 11-12)

Economic activity in Iraq plummeted after the Gulf War and a few of the semi-reliable indicators showed output and living standards fell sharply after $1991.60 \%$ of the population was heavily dependent on the government-provided food ration for their livelihood. Beneath the sanctionsauthorized oil sales, an illicit economy flourished, spawning powerful criminal elements. In short, the Iraqi economy was far less resilient in 2003 than it was at the start of the Gulf War. It emerged from OIF with a much-reduced stock of physical and human capital, making recovery far more difficult. Postconflict authorities were advised to ensure effective systems were in place to pay government employees-especially teachers, health care workers, police, and firefighters-because these payments help jumpstart an economy and ensure at least some families in every community are receiving a regular income. (Dobbins, et al: 192-94, 215; Bowen, 2009: 4)

62 people from USAID’s Disaster Assistance Response Team (DART) - the largest ever fieldedfollowed quickly upon the heels of the invading force in March 2003. When they reached the port where $60 \%$ of Iraq's Oil-for-Food imports were unloaded, it was in poor, but working, condition. All seemed to be going well-there were no major signs of a humanitarian crisis and no chemical weapons were used. During the next three days, however, the situation deteriorated rapidly. Coalition soldiers cautioned 
they did not have enough troops to stop the looting, and more than 200 residents carried off every useful piece of equipment at the port, setting back rehabilitation work by weeks. (Bowen: 81-82) Baghdad descended into chaos as second-order effects of the invasion occurred. Telephone service ceased; explosions broke pipes, causing sewage to contaminate the water supply; and power surges shorted out the city's electrical grid. The looting quickly changed into organized theft. One group smashed through a wall and used a crane to remove valuable precision-milling equipment for the manufacturing of Scud missiles. Millions of dollars in cash stored in bank branches and at the Central Bank were looted or destroyed, as were the contents of safe deposit boxes. The chaos reigned for several weeks, with buildings being set on fire even after coalition officials tried to occupy them. This looting delivered a fatal blow to the country's infrastructure. Damages to power plants, water treatment units, and oil production and refining facilities were massive. Of the total damage, only one-third was caused by the war. The remaining $\$ 943$ million was from looting. (Id: 80, 86-87; Bridoux: 114)

In the coalition's first days in Baghdad, communication was one of the most pressing logistical challenges. With the telephone exchange down, it was impossible to reach Iraqis, and commercial equipment also failed, leaving Baghdad teams out of touch with their regional headquarters. Reconstituting records ${ }^{14}$ and scrambling to find alternative work space for almost the entire central government consumed enormous resources. (Bowen: 85,91$)$ Insurgents quickly learned that in order to be successful, the U.S.-led reconstruction efforts needed to deliver essential services to the population; consequently, sabotage and attacks on these services became a pillar of their strategy, proving fatal to the CPA's objectives. This strategy proved lethal to the restoration of services, and the resulting

\footnotetext{
${ }^{14}$ Bank managers had personally safe-guarded the financial data of customers at 170 branches across Iraq. The director of computer services at the Ministry of Trade secured the list of every Iraqi household eligible for food rations. After the official list vanished amid the looting, this copy was later used as a basis for registering voters in Iraq's first democratic elections. (Bowen: 79)
} 
deprivation led to further discontent and suspicion regarding the efficiency of the reconstruction as whole. (Bridoux: 114)

The coalition's worst surprise was that after decades of mismanagement, Iraq's administrative, social, and physical infrastructure was in a sorry state. The dream of using Iraq's supposedly developed infrastructure to help the reconstruction effort, especially in the oil sector, vanished. (Id: 94) Damage to the electrical grid was also a major post-war problem. By mid-April, looting had reduced Baghdad's power supply to one-fifth of its pre-war levels. In mid-July, CPA efforts had only managed to increase it to half of pre-war levels, working on a three-hours on, three-hours off schedule. (Fallows, 2004)

The water systems under Saddam Hussein were obsolete and even more neglected than the power system. Untreated waste water flowed directly into the Tigris and Euphrates, the main sources of water for the country, causing numerous diseases. (USAID, 2005: 30; UN Development Group and World Bank Group, 2003: 21) Similar to the electricity sector, the deplorable state of the water infrastructure caused major reconstruction delays because of years of negligence, lack of maintenance, looting on a grand scale, and minor damages from the bombing campaign. (GAO, 2007: 20-2) The early occupation authorities initially seemed to recognize the problem, and a $\$ 680$ million water reconstruction project was granted to Bechtel, a private corporation. The contract required the water supply to be repaired within one year. Bechtel was also selected as the prime contractor for the $\$ 4.6$ billion sewage project, but neither project was ever finished. ${ }^{15}$ (Van Buren, 2011: 64)

The U.S. was betting on prosperity for Iraqis as a means to enhance stability; however, dire security conditions kept hampering economic reconstruction. The continuous lack of security saw projects delayed, costs rise, and foreign contractors pulling out. Fraud and abuse in the awarding of

\footnotetext{
${ }^{15}$ A 2007 report by the Special Inspector General for Iraq Reconstruction (SIGIR) noted that Bechtel was paid for most of its work in Iraq. The contract short-comings were cited as being caused by lack of security, and not the fault of the company. The SIGIR report stated this was the problem for most of the contractors in Iraq. (Bowen, 2007)
} 
contracts by U.S. agencies, endemic corruption in Iraqi ministries, and the lack of Iraqi expertise in budget planning and implementation also contributed to the feeble progress of the Iraqi economic reconstruction. Promises made by the CPA did not rely on realistic accounts of preconditions and contributed further to disbelief and discontent among the Iraqi population. Progress in the economic arena became intimately linked to progress in the security field as a lack of economic opportunity caused some Iraqis to join the insurgency. ${ }^{16}$ (Bridoux: 170-71)

Some of the occupation troops who left Iraq in late spring and early summer 2003 were U.S. Army Engineer units who could have played a significant role in the budding reconstruction mission. The loss of these units due to policy disconnects and command short-comings hampered the coalition's ability to carry-out quick-impact reconstruction projects. (Bowen: 98) It was not until October that electricity production reach pre-war levels, or significant progress was made in water treatment. In late spring 2004, after 13 months of activity, the Iraqi power system was still being reconstructed. The frustration of the Iraqis was understandable, even though Bremer argued their expectations were unrealistic given the state of the infrastructure and the dire security conditions. Recurrent attacks on power plants, supply routes, and foreign contractors dramatically slowed down work. By June 2004, all power programs operated by non-Iraqis were halted. (Barton and Crocker, 2004: 60; Energy Information Administration, 2007: 11; SIGIR, 2008: 123)

The economic strategy of the CPA consisted of relying on the oil sector to foster long-term growth while diversifying economic activity, but these objectives were impossible to achieve without power and water. Moreover, essential needs had to be addressed to assuage the population. Oil, electricity, and water production were intimately linked, as oil was needed to produce electricity, which was needed to deliver water to households. Iraqis were expecting marvels from the most powerful and

\footnotetext{
${ }^{16}$ As part of the author's pre-deployment training, it was explained that various insurgent groups would pay $\$ 50$ for every bomb or IED placed. After the invasion and subsequent economic downturn, most professionals in Iraq were barely making $\$ 400 /$ month.
} 
technologically advanced country in the world, but occupation authorities made a mistake by announcing unrealistic targets regarding the provision of these three services and ultimately failing to deliver. This was due mainly to ignorance of the state of Iraqi infrastructure. (Feith 2003a; Barton and Crocker: 59)

The CPA also attempted to liberalize trade and open the door to foreign investment by permitting $100 \%$ foreign ownership of most types of Iraqi businesses. ${ }^{17}$ Tariffs on foreign trade were abolished and a meager tax was placed on imports and exports. But Iraq attracted virtually no foreign investment because of rising insecurity and instead was flooded with consumer goods-air conditioners, refrigerators, cell phones, cars - craved by a deprived public. While this allowed a new merchant class of retailers to flourish, it did nothing to get indigenous industries started. (Marr: 269-70)

Early in his tenure, Bremer began pursuing a program aimed to move Iraq toward a free-market economy by shutting down unprofitable, state-run industries. Unfortunately, this had the political effect of alienating the middle class, which was full of managers from these industries. (Ricks, 2006: 165) Before the war, these 192 state-owned-enterprises (SOEs) served as the sole providers of essential public utilities and the leading providers of a large number of public goods and services. They were the backbone of Iraq's non-oil economy, accounting for $90 \%$ of the nation's industrial capacity. The CPA cancelled their accounts and discontinued budgetary support, believing SOE assets should be preserved for use on the open market. It was theorized the "good" SOEs could be privatized and eventually prosper in a free-market economy. These steps were taken quickly because economists posited that without adequate financial records it would take up to two years to determine the status of each organization. (Bowen: 175-76) Some argued this plan would sink most of the companies, however, leaving Iraq without a manufacturing base. It soon became apparent none of the enterprises were economically viable and no buyers could be found. Rather than being resuscitated, the factories were

\footnotetext{
${ }^{17}$ This CPA order excluded insurance companies, natural resources, and banks from foreign ownership.
} 
purposely neglected, contributing to ever-rising unemployment. In the end, the CPA realized it would need to provide funding for at least one-third of the companies in order to deliver goods and services to support reconstruction. (Marr: 269)

In addition to structural measures, another effort to develop the private sector consisted of launching a small- to medium-business loan program. These reforms, am attempt to globalize Iraq's economy, did not address immediate needs: restoration of essential services and rampant unemployment. Reforms geared toward a market economy seemed off the mark and largely theoretical to the everyday citizen, since Iraqis did not see how these reforms would improve their daily lives and instead saw foreign contractors as the main benefactors of CPA programs. (Bridoux: 113) It took too long for the CPA to realize restoration of essential services went to go hand-in-hand with creating a free market economy.

The most successful measure taken by the CPA was the stabilization of Iraq's currency. It made the Central Bank an independent institution, responsible for monetary policy. This helped reduce inflation, which unquestionably improved standards of living for the middle class and prevented a complete collapse of the economy, but it also increased demand, which could not yet be satisfied. In the absence of sufficient expansion of local industry and services, unemployment remained high. Like most CPA projects, this one began to flounder. Difficult trade-offs had to be made between short-term and long-term goals. The result was most of the CPA's economic moves toward a market economy being reversed. (Marr: 269-70) By October 2003, disagreement within the coalition's ranks over the scope of reform measures, combined with Iraqi opposition, stalled the attempts to create a free-market economy. The security situation made it impossible to tackle major issues, such as the state subsidies for food, electricity, and fuel. By early 2004, the CPA set aside its plan to implement a full free-market economy because of weak Iraqi buy-in. (Bowen: 178) 
Getting the agriculture sector fully developed was also considered essential: it was usually the second-largest contributor to Iraq's GDP, employed $25 \%$ of the workforce, and helped to feed the 18 million urban dwellers. Both the CPA and USAID launched a modernization program, but the sector's heavy dependence on electricity and water did not allow it to develop according to plan. The lack of a sustainable power source caused water shortages, shortening the production season, which impeded progress and severely limited job creation. (SIGIR, 2008: 130-32)

The CPA incomprehensibly neglected the near-term unemployment problem, which likely would have improved living conditions of the population. In 2003, 50\% of Iraqis lived below the poverty line and $60 \%$ were food insecure. Generating jobs should have been a priority, but this also proved beyond the CPA's capability. (Bridoux: 113) In early May 2003, Iraq's ministries were bankrupt, unable to pay salaries and pensions. At the time of invasion, Iraq had two million public employees and half a million pensioners. By the time the invasion wound down, six weeks had passed during which no salaries were paid to any of these individuals. The CPA did eventually begin paying them, but only in amounts ranging from $\$ 50$ to $\$ 200$ a month. Rather than coming from Iraqi-generated revenue, cash was brought over by the planeload from the Federal Reserve Bank in New York. (Bowen: 74, 169-70) The average skilled worker in Iraq made about \$10 an hour (Van Buren: 206), so these "salaries" were insufficient.

Unemployment was eventually identified as another dimension of the reconstruction that could play a role in enhancing the security situation. Bremer realized high unemployment combined with Iraq's young population were an explosive combination. (Bremer, 2006: 71) Most Iraqis had a choice between working for a foreign contractor or the U.S. and risk becoming a target for insurgents, or work for an Iraqi company or state-owned enterprise for a wage too low to support a family. The CPA waited until February 2004 to design measures to fight unemployment through macro lending programs. The lack of security again proved critical, as threats to local bankers prevented participation. A National 
Employment Program, aimed at creating 100,000 public sector jobs, was launched, but lack of investment and security slowed down the program; it reached only $50 \%$ of its goal. (Bridoux: $119-20)$ Adding to the gloomy picture was the predominance of oil in the Iraqi economy. Where oil dominates the economy, ambitious individuals seek to benefit from the massive flow of money pouring into the state. The easiest way to capture this wealth has been to corner political power and steal the funds. Governments in oil states tend toward staggering excesses and waste, as the oil revenues are not invested to create a diversified economy or productive and educated workforce capable of sustaining development. (Diamond: 22-23) Iraq's oil resources are largely untapped, with costs of production among the lowest in the world, so it constitutes an interesting opportunity for foreign investors (Bridoux: 118). But in a country with the fourth-largest proven reserves, people faced shortages and 70minute waits at fuel stations (Wong and Fisher, 2004: 200). Without fuel, electric plants could not produce electricity, yet without a steady supply of electricity, crude oil could not be refined into fuel. In May 2003, production was only one-eighth of pre-war levels (Bowen: 90$)^{18}$. Iraq's refineries did not meet demand until 2004, and then only briefly. Insurgents targeted pipelines and other facilities on a regular basis, threatened workers and contractors, and shut off access to oil production sites, contributing to a dramatic slow-down of repairs and modernization. Smuggling and corruption resulted in $10-30 \%$ of refined fuels being diverted to the black market or smuggled out of Iraq. (Bridoux: 116; GAO, 2007: 12-13)

The CPA pumped \$65 million into South Central Iraq in its first six months, meant to feed a boom in construction. The area had rich clay deposits and some of the finest land in the world-it was Mesopotamia, the Cradle of Civilization. The land was littered with archeological sites in the heart of ancient Babylon, which could make Iraq one of the greatest tourist destinations in the Middle East. But

\footnotetext{
${ }^{18}$ This lack of electricity also shut down water-pumping stations, resulting in a $50 \%$ loss of potable water in Baghdad. (Bowen: 93)
} 
the money was invested in profitable contracts for American corporations not able to deliver because of security conditions on the ground. (Diamond: 120) The same money-in the form of raw cash-could have been put into programs at the community level to employ Iraqis in the rebuilding of their country. The risk of local corruption would be a small price to pay to get Iraqis employed in large numbers, mobilize communities, and repair infrastructure. As it was, there was contract mismanagement on a much larger scale. By June 2004, the CPA was only able to spend a fraction of the $\$ 18.4$ billion appropriated by Congress the previous November, despite the towering need in all areas of the country. (Id: 307-08) Often, military commanders would step in to cover financial breaches with their own funds through the Commander's Emergency Response Program, which had been set up to enable local U.S. commanders to respond quickly to urgent humanitarian and reconstruction needs. But these funds were not intended to pay monthly salaries of public officials, and the wells started to run dry. (Id: 116) Regional disparities began to grow, with the relatively stable and secure Kurdish areas in the north doing better economically than much of the central and southern portions of the country (Marr: 247).

To bolster its cultural awareness and outreach, the Pentagon created the Iraq Reconstruction and Development Council (IRDC). The IRDC embedded 150 members as technical advisors to Iraqi ministries and provincial offices. Most of these were American citizens and Iraqi exiles, giving them ambiguous status among the population. They brought potentially troublesome political baggage, including ties to factions controlled by exiled politicians. The program itself was far from successful, with a great deal of attrition. By June 2004, only 27 members remained. A post-mortem of the IRDC-which cost $\$ 33$ million - found it suffered from poor planning and inadequate management. Its ad hoc creation was no substitute for a standing corps of U.S. government employees who knew the region and spoke the language. (Bowen: 104-05)

The macro-economic reforms did little to improve living conditions in Iraq. Instead of generating hope and consent, they showed foreign contractors as the main beneficiaries of economic investment. 
The opening of markets to foreign investors was seen as coercion-an organized looting of the country's resources while the people's basic needs were not being met. Hostage of the security situation, the CPA failed at nearly every level of the economic reconstruction, which only served to fuel the insurgency. (Bridoux: 171) Electrical grids could not be revived, oil facilities could not be repaired, reconstruction jobs could not be commissioned, supplies could not be delivered, civil society could not organize, and a transition to democracy could not move forward because of the pervasive terrorist, criminal, and insurgent violence (Diamond: 291).

At the end of the CPA's tenure in June 2004, there was little improvement in Iraqi living standards and unemployment was still high-around 36\%, with 60\% concerned about losing their jobs. (Id: 119; CPA, 2004; Barton and Crocker: 51) Any short-term positive effects were undone by the CPA's radical efforts to re-shape Iraq from the top down. ${ }^{19}$ That effort-ideologically driven, ill-considered, and woefully under-staffed-destroyed more than it built. It dismantled the entire institutional structure of the old regime, but had too few resources, staff, or time-and too little understanding of the country-to construct the building blocks of the new Iraq. (Marr: 266-67)

\section{Summary}

In 1945, there was concern the American people-and, indeed, most of the world-would not stand for a successful German and Japanese economy. But both General Clay and MacArthur understood the self-sufficiency of these nations was vital to ending the occupations and, in the long run, would save the Allies time, effort, and money. General Clay chose to ignore orders to only rebuild Germany to the extent necessary "to preserve order and prevent significant unrest". Clay was an engineer, an expert on reconstruction, and knew it would take more than a subsistence-level economy

\footnotetext{
${ }^{19}$ Many of these decisions and their implementation are the focus of Chapter 5.
} 
to get Germany back on its feet. Bremer, on the contrary, was a diplomat, and while this may be valuable in government meetings, it seemed to fall short when it came to rebuilding a nation.

The CPA seemed to repeatedly struggle with the fine line between short-term project performed by Americans and long-term efforts to repair the nation. U.S. forces in German used Army trucks to bring in the harvest, but the Germans had to plow and tend the fields themselves. Both Germany and Japan suffered from a shortage of able-bodied men, but-as the insurgency would illustrate-Iraq was overflowing with them. Iraq's infrastructure may have been old and decrepit, but Russia had removed $95 \%$ of Germany's industrial machinery, whereas Iraq still had $1 / 5$ of its power supply, even after the looting. Germany also had no fuel to run the little infrastructure that remained, while Iraq had plenty of oil. There was a world-wide food shortage in 1945-46, but in 2003 there was no reason Iraq could not feed itself, either through production or imports. Instead, the average health of Iraqis declined after the occupation began. Most notably, occupation forces allowed $2 / 3$ of the damage to Iraq's infrastructure to occur while they stood back and watched; thus, most of the problems listed above were of the United States' own making.

Previous scholars discussed how the Iraqi economy was not as resilient in 2003 as it was in 1991, after the first Gulf War and before the sanctions regime began. This is undoubtedly true, but the same thing must be said of Germany and Japan. Could anyone reasonably believe the economy of either nation was more resilient in 1945 than they were in 1941, or 1937? Those nations also faced severe losses of human capitol. Others point to inabilities to communicate with Iraqis because of destroyed phone lines, yet U.S. forces somehow transmitted messages across war-torn Europe and Asia in 1945. This seems to be another argument rooted in the feeling that if things could not be accomplished easily-or in the now-accepted customary way-it was acceptable for officials in Iraq to simply wait for them to get better. It is as if most occupation staffers could not accept the fact the job was going to be so difficult. 
Perhaps in Iraq, the U.S. should have done what it did in Japan: provide Iraqis access to, but not control of, the resources needed to rebuild their country. In Japan, industrial leaders were not purged because of the effect it would have on the economy. State-owned enterprises continued to run, providing vital resources for reconstruction and serving as a source of steady employment. But Bremer shut down Iraq's government-owned businesses. Advisors were brought in to develop small-to-medium business plans, but it was not safe enough for most citizens to go out shopping. And millions of dollars were spent on contractors, rather than putting local Iraqis to work. A market economy means little if the people do not have clean drinking water.

Bremer and the CPA thought Iraq's economy would be flourishing in 6-12 months, largely because of their oil reserves. How did this assumption align with the expected massive humanitarian crisis? Even accepting this contradiction, how was the relatively small force going to deal with the logistics of the situation? Garner's initial ORHA staff had only a few hundred people. And, was there really a belief that, in the aftermath of a humanitarian crisis, the economy would be kick-started in a matter of months? Was it truly thought Iraqis with no previous government experience would be capable of running in the country effectively in less than a year? These are all questions earlier works seem to have over-looked when simply stating Iraq lacked economic capitol Germany and Japan possessed, which, as this section has illustrated, is not even true. The above information seems to indicate Iraq was largely on the positive side of the scale when compared to the conditions of these two nations in 1945. Therefore, some other explanation is needed as to why U.S. efforts there did not bear fruit.

\section{Legitimacy of Occupation}

Post-World War II, a formal war was followed by unconditional surrender-a decisive defeat over an entire nation, not just a hated regime (Maulucci, 2008: 122). In 1945, there was no question 
someone would need to oversee the reconstruction and stabilization of war-torn Germany and Japan, if for no other reason than to prevent anarchy in Europe and Asia. Both countries were facing food shortages and suffered from massive destruction of both public infrastructure and private property. Their governments and economic systems were near collapse. The occupations were founded on both the Potsdam Declaration and the surrender of Germany and Japan. In 2003 Iraq, however, the occupier somewhat unilaterally decided occupation was necessary, raising serious concerns about the right of the United States to rebuild a nation it decided to proactively invade. International acquiescence to the occupation of Iraq did not occur until AFTER U.S. forces reached Baghdad. Even after a UN Security Council resolution granted the U.S. and Britain occupier status, worldwide opinion of the invasion was still low.

In all three occupations-Germany, Japan, and Iraq-intellectuals were in charge of formulating the message to gain consent to the ruling ideology and to the organization and running of the government apparatus. Within Germany, Japan, and Iraq, there were two sets of intellectuals acting in two different ways. First, there was the occupation personnel, Washington-based officials, think tanks, and academics who formulated or influenced policies structuring the reconstruction of the occupied territory. Second, there was a layer of technocrats, civil servants, and opinion leaders co-opted, trained, and indoctrinated by the U.S. to perpetuate the governing ideology. (Gramsci, 1971: 12; Robinson, 1996: 33-35; 37-38) The Germans and the Japanese may not have liked being occupied, but they knew occupation is what happened when you lost a war, and this message was clearly and consistently sent by both intellectual groups. It was difficult for German or Japanese citizens to argue their defeat when their militaries agreed to unconditional surrender, Hitler shot himself, and the Emperor urged everyone to obey the Americans. On the contrary, in Iraq a regime was deposed, but a country was never defeated. The vast majority of Iraqis were delighted to have Saddam and his henchmen thrown out, but few were happy to find a foreign, non-Muslim army occupying their country. 


\section{Germany}

Post-World War II, the legitimacy of the occupation governments was unquestioned, supported by American allies and the surrounding nations. Allied preparations for the postwar occupation of Germany began during the second half of 1944 . Most of the planning was carried out by the European Advisory Commission (EAC), which recommended the creation of a tripartite U.S., Soviet, and British agency to conduct German affairs following the surrender. (Working Security Committee, 1944: 102) In August 1944, the U.S. government established the United States Group to the Control Council for Germany, which served as a liaison group within the EAC for planning the future occupation. After much internal discussion on how to approach post-war Germany, the U.S. Joint Chiefs of Staff (JCS) promulgated JCS Directive 1067 in April 1945, with the stated objective to establish a "stern, allpowerful military administration of a conquered country, based on its unconditional surrender, impressing the Germans with their military defeat and the futility of any further aggression." In substance, JCS 1067 directed dissolution of the Nazi party; demilitarization; controls over communication, press, propaganda, and education; reparations for countries desiring them; and decentralization of the German government. (Dobbins, et al, 2003: 7)

In May 1945, German military forces surrendered unconditionally to the United States, the Soviet Union, and the United Kingdom following a war in which Germany was the initial aggressor. It was later realized, however, this could cause legal issues, since the civilian government of Germany had not surrendered ${ }^{20}$. Therefore, in June 1945, the four occupying powers of France, Britain, the U.S., and the Soviet Union signed a Common Declaration Regarding the Defeat of Germany confirming the total dissolution of the Third Reich and the consequent termination of any Nazi governance over the nation.

\footnotetext{
${ }^{20}$ The Allies wanted to overcome this legality because Hitler had used the reverse argument-surrender of the government but not the military-to create his "stab in the back" rationale following World War I (Ziemke, 1975: 109)
} 
The Allies had already decided to occupy Germany militarily, and each established military governments in their respective sectors. Actual exercise of power was carried out according to the Agreement on Control Machinery in Germany signed by the U.S., Britain, and the Soviet Union in November 1944. Germany was divided into three zones of occupation (with the French zone being added later), each ruled by the Commander-in-Chief of the respective occupation forces. The American zone consisted of Bavaria and Hesse in Southern Germany, as well as two ports in Northern Germany. ${ }^{21}$ The U.S. sector was organized under the command of the Office of Military Government, United States (OMGUS). Matters affecting Germany as a whole, however, would have to be decided jointly by all of the Commanders-in-Chief, who-for this purpose-formed a single organization known as the Allied Control Council. The Council would ensure "appropriate uniformity of action by the Commanders-in-Chief in their respective zones of occupation." (Dept of State, 1947: 3-5, 81)

Within the zones, each occupier ran its own administration. Since real power lay in the hands of the separate Allied governments and their military governors, the Council was unable to impose its resolution for many issues (Allied Control Authority, 1945). ${ }^{22}$ In practice, each of the four occupying powers wielded full governmental authority in their respective zones and carried out different policies toward the population and local and state governments. Occupying powers had little influence over other sectors, except for small concessions gained through Control Council procedures.

Japan

In Japan, the United States took the lead in the occupation because it played the predominant role in the final phases of the Pacific war. Unlike Germany, there would be no zones and no division of responsibility. Potsdam did not limit the actions the U.S. could take in carrying out the occupation, so

\footnotetext{
${ }^{21}$ This was because the Americans requested to have a toe-hold in the northern part of the country.

${ }^{22}$ The original plan was to govern Germany as a single unit through the Control Council, but this broke down in 1946 due to growing tensions between the Allies.
} 
they hoped to avoid the most troublesome aspects of the German occupation, where policy formulation and implementation was slowed and sometimes blocked by the need to forge agreements among the four parties. The Americans did not recognize any legal constraint on the range and extent of authority, with the exception of international laws governing the proper treatment of civilians. (Dobbins, et al, 2829; 31)

U.S. forces began entering mainland Japan just after Emperor Hirohito surrendered on August 15, 1945. President Truman named General Douglas MacArthur as Supreme Commander Allied Powers (SCAP) and placed him solely in charge of Japan's occupation, his powers often equal to those of a Roman Consul (Schonberger, 1989: 45-50; Wolfe, 1984). MacArthur understood the symbolism of Japan's emperor as both the head of state and commander in chief. He conducted his own leadership of the country in a somewhat distant and remote way, rarely allowing visitors, and then only VIPs. Traveling by limousine (never without armed escorts) and working ensconced atop one of Tokyo's most lavish buildings, MacArthur mirrored Hirohito's imperial manner. (Weintraub, 2011)

Since the unification of the country in 1603 , the Japanese people had grown accustomed to stability; unity and obedience; to living austerely; to devoting their lives to fighting for the emperor; and to respecting the values of loyalty, hierarchy, collectivism, filial piety, and emperor worship (Grew, 1942: 17, 29-30; Emmerson and Holland, 1988: 33; Reischauer and Craig, 1989). In addition, willingness to adapt in order to develop was deeply ingrained in the Japanese mentality, the aim being to show the Japanese themselves were as responsible, organized, and modern as the West (Hirakawa, 1989: 435; Beasley, 1990: 9; Westney, 1987: 10-18). MacArthur embodied the same strength of character and charisma as the powerful shogun who kept Japan safe for centuries. Such a strong character helped the American project, as the Japanese people historically always looked for a leader. Throughout his time in 
Japan, MacArthur enjoyed huge popularity. ${ }^{23}$ Within weeks, MacArthur had established his command in Tokyo and begun an astonishing round of reforms. He quite strategically utilized the emperor and other members of the royal family to assist in his efforts, and was soon viewed as both liberator and savior, more powerful than even the emperor himself. ${ }^{24}$ (Jennings, 2003: 16)

America believed most Japanese soldiers would obey the emperor's order to surrender and cooperate with the occupation authorities. Nonetheless, there was some concern the occupation forces could meet intermittent, and possibly even concerted, resistance from dissident elements. In the two weeks between the Japanese acceptance of the surrender terms and the arrival of the occupying force, a newly constituted cabinet under the Prime Minister (who was also the emperor's uncle) began the process of demobilizing Japan's army and navy. Members of the royal family were dispatched to China and elsewhere to oversee the surrender of Japan's troops stationed abroad. The Japanese government also engaged in a public relations campaign to counter pervasive rumors the U.S. occupying force would be brutal and violent to Japanese civilians. Once the occupation was underway, MacArthur sent troops and civil affairs officers on rounds of motorcycle diplomacy throughout the country to establish security and explain U.S. intentions while managing local expectations of the military government (Jennings: 910).

In August 1945, MacArthur instructed the Japanese government to establish a liaison office to interact with SCAP headquarters. The Central Liaison Office was located in Tokyo and staffed by the Foreign Ministry. Liaison offices were also set up in each prefecture to serve local military government teams. The Central Liaison Office functioned as the primary channel for communication between the SCAP special staff sections and the Japanese government. (Dobbins, et al: 32) In January 1946, the

\footnotetext{
${ }^{23}$ In 1946, the Japanese quickly bought every translated copy of MacArthur's autobiography, and more than 200,000 Japanese citizens gave him a joyous send-off when he left Japan in 1951.

${ }^{24}$ MacArthur used tactics such as refusing to visit the emperor; rather, he made the man come to him. He rarely allowed visitors, though he received more than half a million fan letters during the first year, thanking him for his work to help the people of Japan. (Jennings: 16)
} 
emperor himself began touring the country in an orchestrated effort to boost morale and support the objectives of the occupation. As Funabashi (2003) and Dower (1999) point out, Japan played the "good loser" by embracing defeat (Id: 33, 39).

Iraq

In contrast to the conflict with Germany and Japan, Iraq's reconstruction followed a unilateral preventative war with an oil-rich country having a lower-tier military. President G. W. Bush wanted to remove Saddam through military force, justifying his actions with the conjunction of terrorism, weapons of mass destruction (WMD), and humanitarian intervention, but the intelligence and facts were fixed around the policy, rather than the other way around. By claiming the right to preventative war and the unilateral use of force when threatened, the United States was quickly identified as a threat to global stability and-more precisely-as a threat to the Arab and Muslim worlds (Tariq, 2003: 5-19).

The story of U.S. legitimacy in Iraq really began in the early 1990s, when Saddam Hussein invaded Kuwait. Since that time, Iraq was continuously under siege by the United States. During Operation: DESERT STORM, large portions of its infrastructure were destroyed. Clever tools such as cruise missiles that spat metallic fibers to short out electrical systems were used. In the intervening years, three U.S. presidents bombed and rocketed Iraq. Meanwhile, sanctions kept Saddam rich from black-market oil profits while chiseling away Baghdad's First World veneer and plunging most of the country's population into poverty. Most of these actions were approved, or acquiesced to, by the United Nations Security Council. ${ }^{25}$ Events in Iraq ebbed and flowed through the U.S. media over the years, but the storm never ended for most Iraqis. (Van Buren, 2011: 5-6)

\footnotetext{
${ }^{25}$ From its invasion of Kuwait in 1990 until 2002, Iraq was the subject of 16 UN Security Council resolutions, all of which either demanded action by Iraq or condemned it.
} 
Army reservist and civilian expert on Middle Eastern security issues, Major Michael Eisentadt, said, "I don't think you can understand [Operation: IRAQI FREEDOM] without understanding the end of the '91 war, especially the distrust of Americans that resulted". In February 1991, President H.W. Bush gave speeches encouraging Iraqis to "take matters into their own hands and force Saddam Hussein to step aside". U.S. Air Force planes dropped leaflets on fielded Iraqi units urging them to rebel. On March 1, Iraqi Army units in southern Iraq began to do just that. But when these Shia soldiers rose up, U.S. forces stood by, their guns silent, while Saddam continued to fight. He launched a fierce internal offensive against the Shia in the south and the Kurds in the north. An estimated 20,000 Shia were killed and tens of thousands of Kurds fled their homes for the mountains, where many died of exposure. (Ricks, 2007: 4-5) Having incited this rebellion-or intifada-the U.S. stood by why the rebels were slaughtered. This failure would haunt the U.S. twelve years later, when their commanders were met with cold suspicion. (Id: 6; Marr, 2012: 232)

The United Nations had never directly administered a post-conflict territory anywhere near the size and complexity of Iraq; rather, UN Security Council Resolution 1483 recognized the United States and Britain as "occupying powers" in Iraq with legitimate authority under international law. The resolution called for "the formation, by the people of Iraq, with the help of the Authority and working with the Special Representative, of an Iraqi interim administration." This was to be a "transitional administration run by Iraqis, until an internationally recognized, representative government" could be established and assume full power. Since Iraqi memories of the British mandate were still fresh, even in 2003, any suggestion of a long-term U.S. or UN "neo-colonial" presence was likely to cause concern within the population. ${ }^{26}$

\footnotetext{
${ }^{26}$ The U.S. soon began construction in Baghdad on the largest U.S. embassy complex in the world-when finished, it would be larger than Vatican City and capable of complete self-sustainment.
} 
Neither the UN nor either of the occupying powers attempted to negotiate their presence with sheiks or other tribal leaders in Iraq, and there was no national surrender. (Bellin: 603) In less than 100 days, Americans came to be regarded by ordinary Iraqis as occupiers rather than liberators; moreover, they were occupiers who-unlike Saddam - could not ensure law and order, or even basic services like electricity and water (Barnett, 2005: 9-10). There was a burgeoning resistance to the occupation, which was crystallizing into an extensive, heavily financed, well-coordinated guerilla insurgency whose popular support was growing. In September 2003, a Gallup poll showed the populace was rife with suspicion of the American occupation. Only 5\% of Iraqis surveyed believed the United States had invaded "to assist the Iraqi people" and only $1 \%$ believed it was mainly to establish democracy in Iraq. Almost half thought it was "to rob Iraq's oil". 94\% said Baghdad was "a more dangerous place today than before the invasion" and $86 \%$ said they or a family member had recently feared going out for safety reasons. (Diamond: 25-26)

Faced with having to implement a counter-insurgency plan, the U.S. found itself with a unique burden. Though European powers are largely unapologetic for their colonial past, the U.S. was born from insurgency and has long proclaimed anti-colonial values, calling for others to withdraw from their overseas possessions. ${ }^{27}$ This has created tension between the principles the U.S. proclaims and the realities of its foreign policy. U.S. political ideology is built upon a rather radical principle, recognizing the right of a populace to "throw off" a government incapable of governing and "provide new Guards for their future security" (U.S. Declaration of Independence, 1776).

Much ink has been spilled on how, when, and above all, why the decision to go to war in Iraq was made. Regime change was advocated by a number of politicians on the right for some time and was justified by several shifting rationales. In retrospect, the absence of a satisfactory settlement of the WMD issue and the withdrawal of inspectors would prove to be the Achilles' heel of the regime. Even

\footnotetext{
${ }^{27}$ This practice goes as far back as the Monroe Doctrine.
} 
though the U.S. ultimately found no WMD, despite asserting this as the main reason for the occupation, had Saddam cooperated more fully on disarmament, the U.S. would have had much more difficulty justifying its subsequent attack on Iraq. (Marr: 238, 269-60)

\section{Summary}

The occupations of Germany and Japan had a high degree of both international and internal legitimacy, important to establishing a workable occupation government. War between the Allies on one side and Germany and Japan on the other was a fight between equals and the surrenders were unconditional; thus, the U.S. spent little time explaining or justifying their actions, a marked difference from what occurred 60 years later. In 1945, the U.S. presented itself as the benevolent leader of the "open" world; in Iraq, the belief that what was good for America would be good for the world exemplified a suspected racist attitude towards expansionism. When the U.S. decided to use coercive power in answer to international terrorism and the threat of Islamic fundamentalism, it found its actions questioned worldwide.

There are points previous scholars failed to make, however. True-Iraq's occupation did not involve the defeat of nation; rather, it came about through the over-turning of a hated regime. But the quick nature by which the U.S. was able to reach Baghdad, with little to no hindrance by the Iraqi Army, evidenced how all-out war between the two nations would have played out. The fact Iraqi soldiers simply went home showed they accepted defeat, under any definition. No other nations came to Iraq's defense, except for issuing declarations condemning the U.S. for its actions. Even Arab nations in the Middle East refused to contribute arms or men, despite their assertion it was an insult having a Western nation in their territory. And most Iraqis were willing to accept Western guidance when it came to rebuilding their nation, though preferably from larger international bodies such as the UN, rather than putting sole reliance on the United States. 
In Germany and Japan, official recognition of the occupations did not come until after formal surrender. There was no preliminary acceptance of occupation by either the German or the Japanese people prior to the cessation of hostilities. The Iraq situation is similar: UN Security Council Resolution 1483 recognized the U.S. and Britain as occupiers in Iraq on May 22, 2003. This resolution was passed by the same nations who threatened to veto any resolution regarding the actual invasion of Iraq. By somewhat reversing their position and accepting the U.S. and Britain's presence less than six months later, their actions would seem to grant as much legitimacy as possible to an international use of force in our current era, short of condoning it prior to the invasion. If the other members of the Security Council-including three with full veto power-did not believe the occupier status was legal, they could simply have voted 'no'. Instead, their actions seem quite political: first refusing to support an action and later approving its outcome.

All three occupations were made legal-and, therefore, legitimate-under the laws applicable at the time, and it seems clear each occupied nation's military accepted further formal conflict was pointless. Instead, the major difference in the Legitimacy of the occupations at issue would appear to be their physical legitimacy. In Germany and Japan, there was a soldier on every street corner and a military detachment in every city and town. In Iraq, the U.S. chose to only physically occupy Baghdad and other select population centers, casting doubt on how "legitimate" an occupation can be when one cannot effectively control. It is the equivalent of a nation establishing a headquarters in Washington, DC, protecting it from attack, and claiming it occupied the United States.

Previous scholars have failed delineate between the legal and physical definition of "legitimate" when it comes to these three nations, thus missing a key factor that could have contributed to Iraq's success. This research shows - at a minimum - that both international and physical legitimacy are required in order for a nation to be "occupied". 


\section{Consistency of Authority}

\section{Germany}

During the final stages of World War II, the U.S. Army was governing areas of Germany as they came under allied control. The Allies faced a vanquished army, but still had to secure the population amidst broken civil and physical infrastructure. Once the zones of occupation were designated by the Allies, Army forces outside the zone repositioned inside the U.S -held territory and assumed occupation duties. The U.S. zone had a population of roughly 19 million, but was only the size of Kentucky

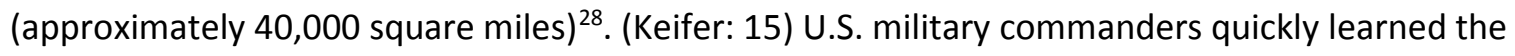
governments they were supposed to supervise were practically nonexistent. In Munich, the government buildings were badly damaged, with the ministries either bombed out or evacuated. (Ziemke, 1975: 26970)

Operation: ECLIPSE was the code name for the occupation of Germany. By ensuring orderly administration of captured territory, civil affairs teams played a vital role in achieving and supporting military success. ECLIPSE actually consisted of two phases: Phase One occurred simultaneously with Operation: OVERLORD, the invasion of Europe, and focused on physical occupation as forces advanced; Phase Two was a complete occupation following termination of hostilities. Phase Two's essential tasks were to disarm the German armed forces, enforce surrender terms, establish law and order, and redeploy Allied forces into the defined national zones. (Keifer, 2009: 14-15) It was accepted that in northwest Europe, the civil affairs teams must be imbedded in the field armies to be assured of military cooperation at the unit level, especially in regard to essential back-up, such as transport or communications. Thanks to such thoroughness, solutions were devised in regard to practical problems of liaison between civil-affairs teams responsible for rebuilding the country and combat military units in the field, and between those teams and German local governments.

\footnotetext{
${ }^{28}$ To put things in perspective, the population of Kentucky in 2016 was just over 4 million.
} 
Meanwhile, large numbers of soldiers were being trained as civil affairs personnel in special centers and 'Public Safety Officers' were being recruited from U.S. and British police forces. As a result of such preparation, soldiers on specially trained civil affairs teams moved into German towns in 1945 alongside leading combat troops. These soldiers occupied local government offices, and swiftly established their authority. These units were later re-named "military government" units to emphasize the fact they were responsible-at least in the short term-for the day-to-day operation of the country. (Barnett, 2005: v-vi, 12)

Overall, the military had no shortage of means in Europe to accomplish their tasks. On V-E Day, 61 U.S. Army divisions were available in Germany. This abundance of troops allowed for rapid disarmament of the German military and police forces. Troops assumed responsibility for law and order, as well as security of all areas. They even secured looted national treasures hidden by the Nazis during the war. The key to the groundwork for success in the occupation was the rapid assignment of units to be responsible for all villages, cities, and towns and to take, control, disarm, and secure all members of the German population. (Id: 15-16) Thus, it was clear to the Germans at the time of surrender who had the authority and control within the country.

Japan

For Japan's occupation, the approach to government was quite different from that used in Germany. The U.S. decided, essentially for technical and language barrier reasons, to maintain a Japanese government to implement the policies and decisions of the occupier. Public trauma caused by Japan's overwhelming defeat was thus partly compensated for by the presence of a Japanese government, since the population would have considered an occupation authority colonial in nature. The government helped maintain a sense of national pride, an element essential in motivating the 
people to embrace the huge task ahead, while the population was still able to locate power in a familiar setting. (Bridoux, 2011: 131)

General MacArthur and his staff acted under military orders laid out in U.S. Joint Chiefs of Staff (JCS) Directive 1380/15. The decision to rule Japan through existing Japanese government machinery was made on the eve of the occupation in order to conserve U.S. forces and resources, meaning there were no trained civil affairs units or liaisons on hand like there were in Germany. (Cohen, 1987: 8-10)

In the initial phase of the occupation, some of the troops were organized into teams distributed across Japan's eight regions and 46 prefectures to oversee reconstruction efforts. Each local team had functional sections dealing with such areas as government, economic, information and education, and public health parallel to the structure of local government. Decisions were made in Tokyo and sent to the governors and mayors for implementation, but it was the job of the local teams to observe and report back to headquarters on how well their decrees were implemented at the local level. (Dobbins, et al: 30) This contrasts procedures used in Germany, where local civil affairs units actually made and implemented numerous policy decisions.

One controversial decision in Japan's occupation was not treating the emperor as a war criminal, bearing the responsibility of starting the war. Some American officials considered it, and even today the question remains at the center of scholarly literature on wartime Japan. The treatment of Hirohito provides the perfect example of the dilemma faced by the occupation: to democratize, but not if it endangered stability. Deposing Hirohito risked civil unrest. As father-figure to the Japanese race, the emperor was a very-much-needed leader in troubled times (U.S. Bombing Survey, 1946: 153-54). SCAP/HQ thus invented a new role for Hirohito: the symbolic leader of a new Japan on the road to peace. (Bridoux: 132-34) This move was crucial in getting the Japanese people to cooperate with the global post-war objectives of the United States (Schonberger, 1989). 
Iraq: Pre-Invasion Decisions Regarding Governance

For Iraq, a mixture of both approaches to governance was attempted, but with mixed messaging and little forethought. No real efforts were made in 2002-03 to understand what the political realities might be without Saddam's iron grip on the various religious and ethnic groups throughout the country, and earlier plans for such a contingency were forgotten and overlooked. In contrast to analyses from the $\mathrm{CIA}$, State Department, and the U.S. Army War College, the Pentagon gave no serious thought to the possibility ousted Sunnis might revolt against the new order or disenfranchised Shias might drive for power, opposing the American ideal of introducing capitalism and democracy in Iraq (Crane and Terrill, 2003:1).

Finding a replacement for Saddam's regime was the most difficult challenge. The U.S. assumption was underlying bureaucratic and military structures would be left to govern Iraq while the top political leadership would be replaced by the exiled opposition to Saddam. The hard core of this group, which had operated outside Baghdad's control in the 1990s and designated to receive support under the U.S.'s Liberation Act ${ }^{29}$, consisted of a mix of Sunnis, Shias, and Kurds. But a gathering of this opposition in London in mid-December 2002 gave an indication of future problems. The Kurds wanted federalism with a high degree of separatism opposed by most others. Most objected to the leadership of Ahmad Chalabi ${ }^{30}$, the apparent U.S. front-runner for Iraq's leadership. Secularists had reservations about others' Islamist agendas. The United States had concerns about one group's ties to Iran. Given these problems, President Bush made a decision to forego any provisional government composed of these opposition leaders and put post-occupation authority in the hands of the United States. (Marr, 2012: 260)

\footnotetext{
${ }^{29}$ The Iraq Liberation Act of 1998 is a Congressional statement that "It should be the policy of the United States to support efforts to remove the regime headed by Saddam Hussein from power in Iraq..."

${ }^{30}$ Chalabi was a western-educated Shia who had strong ties to the CIA, but he had not lived in Iraq for more than 30 years.
} 
The Americans ultimately invaded Iraq without any clear plan for a future government. Rather, the Pentagon established the Office for Reconstruction and Humanitarian Aid (ORHA) under Jay Garner with the mandate to prepare for a potential humanitarian crisis in the direct aftermath of the invasion. ORHA was never tasked to deal with major reconstruction projects or to set up a new political order. In the absence of a comprehensive plan for the reconstruction of Iraq and without the inclusion of efficient Iraqi insiders, the U.S. contributed to the legitimacy gap discussed above. The Iraqi population did not trust the exiled leaders, who were seen as walking in the trail of the invading forces. (Bridoux: 92)

When Garner was presented to the media on March 11, 2003, among the principles he laid down for Iraq's reconstruction was the U.S.'s obtrusive role would be short and Iraqi security institutions would continue to exist. He relayed, "We intend to immediately start turning some things over, and every day we'll turn over more things." As for the Iraqi military, a "good portion" would be used for reconstruction projects and would continue to be paid, thus avoiding putting a lot of unemployed soldiers on the streets. These plans would be reversed a mere eight weeks later. (Ricks, 2007: 104)

Upon his arrival in Bagdad on April 21, 2003, Garner continued to insist the United States would leave as soon as possible, stating his contract ran out in August and he would be gone by then, along with the American occupation. These statements were well-intentioned: to signal the Iraqis the United States did not intend to impose a protracted occupation on them. But what the Iraqis observed was a bungling, wavering American presence, in which no one was really in charge. One of Garner's senior staffers finally got through to him the Iraqis were fearful of a repeat of 1991: "What the Iraqis are hearing is a second betrayal-that we are going to bug out on them and leave them to the thugs, criminals, and Baathists." But by then, it was too late to change the message. (Diamond, 2005: 32) Most experts agree Iraq's biggest advantage to nation-builders was its nation-wide civil administration, which was relatively efficient under Saddam. In its study of America's role in nationbuilding, the RAND Corporation recommended not reconstructing Iraq's administration from scratch, 
but rather rebuilding it and staffing it with Iraqis to reduce the need for direct international intervention and facilitate security and development across the country. (Dobbins, et al: xxvii) The report went on to note that since Iraq's population had little experience resolving their political differences peacefully and since the proliferation of weapons and armed groups was so great, forming Iraq's police, military, and security services must be a priority. Compared to other cases (such as Kosovo, Somalia, and Afghanistan), Iraq benefited from having a strong state capable of imposing order on society. In dealing with threats to security, the United States would have to take prompt action to restructure these forces so they could be deployed for national defense, internal security, and constabulary duties. (Id: 170, 172)

Iraq: The Invasion

Operation: IRAQI FREEDOM (OIF) was over in virtually three weeks. The main objectives were the capture of Baghdad, the defeat of Saddam's forces, and the fall of the regime. The operation began with an air campaign meant to "shock and awe" Iraqi forces on the night of March 19 (the morning of March 20 in Baghdad). It targeted key regime strongholds, command and control facilities, and military installations, but not oil infrastructure or electrical grids, since these would be needed to rebuild the country. The backbone of the campaign was the major ground offensive designed for speed and surprise, in order to reach Baghdad as fast as possible, surround it, and capture it, thus ending the regime. The campaign was specifically designed not to occupy urban areas along the way, since it was expected the local population would be friendly, if not openly welcoming. After crossing the border on March 21 (local time), combined U.S. and UK forces first protected the major southern oil fields. British units then secured key areas in the south while the main arm of the invasion force headed north along the Euphrates. There was some unexpected resistance from one of Saddam's guerilla forces, but U.S. forces reached the Baghdad airport on April 4. Two days later, soldiers arrived at the Republican Palace-the nerve center of Iraq's government-and established their own headquarters. (Marr: 261) 
Operations in the north of the country went somewhat differently. Denied passage by the Turkish government, the U.S. was without a northern route for its forces to enter Iraq. Thus, together with U.S. Special Forces and airpower, heavy reliance was placed on the Kurdish militia, the pesh merga. They encountered resistance from a radical Sunni Islamist group, but those fighters eventually dispersed. However, without proper border security, many made their way back into the country and later helped to found al-Qaeda in Iraq (AQI). It also proved impossible for the limited U.S. forces to control the pesh merga, who took advantage of the situation by expanding their influence in Kurdishdominated portions of the northern provinces. (Id: 262)

The U.S.'s approach to the invasion was based on the Pentagon's preference for "rapid decisive operations", referring to the potentially devastating and cumulative effects of using technology to fight so fast and adeptly the enemy would never have a chance to catch up. Confused and overwhelmed, the enemy would break. Thus, when marching to Baghdad, U.S. forces substituted speed for control and stopped moving once they reached the capital. One officer later stated the operational concept had hamstrung American commanders as they entered the country because it prevented them from getting a realistic assessment of the situation. It was not until much later that military strategists began paying attention to the basic human elements in Iraq: tribes, blood feuds, and fights over water, money, and women. Only then did they begin to understand the war they were fighting, which Clausewitz maintained was the first and foremost task of a military leader. (Ricks, 2009: 160-61)

By mid-April, it was clear the regime had been toppled and its forces defeated, but the country was hardly occupied. Coalition forces were spread extremely thin and had established control only of some northern towns and in the Sunni center of the country. Their control of Baghdad would prove tenuous. The entire operation had been based on economy of forces, with the United States operating under the assumption of an early withdrawal and quick turnover to an Iraqi administration. By June, U.S. forces would be drawn down to about $60 \%$ of their original size. (Marr: 262-63) 
Unlike Germany's occupation, the lack of follow-on forces to secure the rear areas was a major problem, allowing for interdiction of communication and supply routes and looting of bypassed areas (Keifer: 21). Even as the enemy capital fell, there was concern, especially from seasoned army officers. "The hard part is yet to come," warned one retired colonel. "We can easily win the fight but lose the peace. If we do not give the people positive signals, and soon, that Iraq is getting better...then the gunmen will start appearing." Yet another colonel was even more specific: "We should not lose sight of the fact that, from the opposing point of view, the war is not over. I suspect that serious people somewhere...are planning the counterattack...general operations to destabilize and deny U.S. efforts to move to a secure and reformed Iraq." (Ricks, 2007: 134-35)

The initial conditions following the demise of the Baath regime proved radically different than what was foreseen by pre-war planning. The collapse of governmental structures leading to widespread looting, the reorganization of loyalists to the Baathist regime, the destruction of the economic infrastructure, and the beginning of a sectarian realignment constituted the realities faced by the victors. The Iraqi army faded away, with soldiers simply going home and police officers not reporting for duty. Americans did not understand the nature of Saddam's regime had not allowed independent thought and leadership development among rank-and-file soldiers; therefore, no subordinates emerged to carry on business as usual (Rathmell, 2005: 1024). The Iraqi state lost all administrative capacity. In a matter of weeks, liberation turned into occupation. (Bridoux: 93-94)

Although some damage was done by the war-especially the bombing-the real costs of the occupation for the Iraqi people came immediately after the fall of the regime. The failure to bring enough troops to control "occupied" cities and establish law and order was a critical flaw and did more to affect the outcome than any military action. In the vacuum that ensued with Saddam's fall, widespread looting by the local population went unchecked for days, even weeks, in virtually all major cities and towns except for the Kurdish areas, where it was stopped by the pesh merga. Mobs attacked 
ministries, hospitals, and universities, as well as communications facilities, the power grid, and industrial plants. Among the most shocking episodes of looting was the National Museum containing priceless treasures. While coalition forces protected oil installations, they had no orders to fire on unarmed civilians and made few moves to control the situation. The result was chaos as the army, police, and bureaucracy disappeared.

The CPA later estimated the cost of the looting at \$12 billion. It devastated Iraq's infrastructure, set back its reconstruction efforts, and undermined what confidence the population may have had in the new administration. The population greeted the foreign forces-at least in some parts of Iraq-with clear relief at being free of the previous regime and with a sense of hope for the future. Much of this was now punctured. The absence and/or weakness of occupying U.S. forces allowed local players to fill the emerging political vacuum. They established "shadow governments" that often operated beneath the radar of the skeletal structures later established by the coalition. (Marr: 263)

Americans were victims of the speed at which they disposed of Saddam Hussein's regime. There were no additional troops to join the invasion force because no plans were made to deal with a sudden collapse of law and order. The U.S. envisioned the Iraqi police and armed forces would ensure security (Feith, 2003: 24). There was also the issue of troop quality: while American forces, as combat troops, were well-equipped to win a war, they were not trained for peace-keeping duties involving interaction with civilians, thus rendering the transition from combat to stability operations difficult (Trip, 2004: 551; Kucinich, 2004: 9; Cavaleri, 2005; Aylwin-Foster, 2005: 2-3). American troops present at these appalling scenes of lawlessness failed to intervene, content to be mere bystanders. In response to the looting, Defense Secretary Rumsfeld said, "Stuff happens! It is untidy and freedom's untidy, and free people are free to make mistakes and commit crimes and do bad things." (The Sunday Independent, April 13, 2003).

But that is not the way the looting felt to many of those on the ground. The U.S. military perceptibly lost its recent gains during this period. It gave the sense it really didn't know what to do next 
and was waiting to pass the mission to someone else. The message sent to Iraqis was far more troubling than the Americans believed: the U.S. government either didn't care or it was incapable of acting effectively. The lack of U.S. response to the April 2003 looting undercut the beginning of the entire occupation. (Ricks, 2007: 136) By the time the looting was over, Iraqi resistance forces were already starting their campaigns of bombing and assassination, and American forces had angered Iraqi opinion by shooting more than a dozen people in a protesting crowd (Barnett: 9).

Iraq: The Power Vacuum

In the late spring and summer of 2003, Baghdad was falling apart in front of the U.S. military, with buildings being demolished and parents afraid to let their children outside, but no one had orders to do anything about it. The U.S. Army $3^{\text {rd }}$ Infantry Division's after-action review confirms there were no orders to stop looters or to restore order in Baghdad, nor was there guidance to create an interim government, hire essential services employees, or ensure the judicial system was operational. (Ricks, 2007: 150-51) The $3^{\text {rd }}$ ID's report goes on to fault the political thinking that led American forces to be declared liberators rather than occupiers, because this led military commanders to operate in a handsoff way, allowing the chaos to increase in Baghdad. The Staff Judge Advocate's section of the report stated, "Because of the refusal to recognize occupier status, commanders did not initially take measures available to occupying powers ${ }^{31}$, such as imposing curfews, directing civilians to return to work, and controlling the local governments and populace." (Id) ${ }^{32}$

\footnotetext{
${ }^{31}$ Articles 42-56 of The Hague Convention and Article 27-34 and 47-78 of the $4^{\text {th }}$ Geneva Convention lay out the duties and obligations of an occupying power. These duties apply whether the UN Security Council has approved the occupation or not, under the guidelines spelled out in the UN Charter.

${ }^{32}$ The one notable exception to the Americans' apparent disregard for the violence was in areas where Army Special Forces operated, in far northern and western Iraq. SF soldiers are much more accustomed to living and working with foreign populations and their commanders quickly moved to empower the locals and co-opt existing power structures.
} 
These results should not have come as a surprise to the U.S. forces. RAND's report warned that, aside from politically motivated violence, any occupation would face three law-and-order issues. The first was social chaos, allowing circumstances in which looting, revenge killings, and general malfeasance run unchecked. The extent of this challenge was illustrated as the regime collapsed. The second was that of banditry, which is endemic in most post-war environments and is fueled by military desertion, the breakdown of social structures, and demobilization. In Iraq, much of the early insurgent activity would actually be better classified as banditry. Finally, Saddam encouraged a return to tribal justice to fragment political opposition, resulting in significant portions of the population being distanced from the criminal justice system. (Dobbins, et al: 178)

Several groups in Iraq had the military capability to make a power grab. Shia radical groups may not have had the whole-hearted allegiance of a majority of the Iraqi Shia population, but they had extensive support networks within the country and the ability to mobilize lightly armed fighters and crowds quickly. It was warned these groups, working under guidance from Tehran, could use violence to assert their authority and exploit popular feelings of insecurity to enhance their political position. The removal of the regime caused rivalries to surface within the Shia political and religious hierarchy. Also, Kurdish groups were reinforced by the seizure of heavy weaponry from Iraqi army units. (Id: 174)

Because of the challenges the U.S. soon found itself facing, Bush decided to replace Garner's ORHA with the CPA, almost before Garner even arrived in-country. The President temporarily vested ${ }^{33}$ the CPA with all executive, legislative, and judicial authority in Iraq. The CPA itself was organized into departments run by senior advisors shadowing Iraqi ministries and charged with complete

\footnotetext{
${ }^{33}$ The exact legal nature and authority of the CPA is unclear. It is possible it was operating under delegated powers from President Bush, as the leader of the recognized occupying power. It could also be it was established in National Security Presidential Directive 24, which details the post-conflict governance in Iraq, though the CPA is not directly referenced by name in that document. As head of the CPA, Bremer reported directly to the President, though he was tangentially connected to the DoD and Dept of State. The legality of the CPA has been studied by both scholars and lawyers. See Elaine Halchin's The Coalition Provisional Authority (CPA): Origins, Characteristics, and Institutional Authority, CRS Report for Congress, June 6, 2005 for more details.
} 
reorganization. (Executive Office of the President, Office of Management and Budget Report, 2003: 11). Ambassador Bremer made the decision there would not be an Iraqi government any time soon (Ricks, 2007: 165), a reversal of course that likely furthered the confusion and mistrust the Iraqis were already experiencing. Instead, the CPA began coordinating with the Iraqi Governing Council ${ }^{34}$, a body of 25 members representing the various political trends of the country, but without any real decision-making power (Feldman, 2006: 115-16; CPA 2003b). In addition to its political arm, the CPA created the Development Fund for Iraq to manage the funds for running the administration and reconstruction of the country, from which Bremer allowed disbursements he deemed to be for the benefit of the Iraqi people. (CPA 2003b)

The one bright spot in the early phase of the occupation was the humanitarian situation was much better than expected; however, this is also sadly ironic, since a humanitarian crisis was the one area the ORHA was especially prepared for, and what U.S. forces were told to expect. Such a crisis might have obstructed the more violent offenders and resulted in more troops on the ground during the early days of the occupation.

\section{Summary}

The Consistency problem in Iraq is obvious: the nation had two different governing bodies in less than a month-the ORHA and the CPA-with the second taking a dramatically difference stance on controversial issues than the first. In Germany and Japan, it was clear who was in control from day one; in Iraq, even a year later, there was confusion among military and civilian departments as to who had

\footnotetext{
${ }^{34}$ This Council was actually started by Garner, who had selected 7 prominent Iraqis to help advise, and eventually lead, the country. Bremer expanded this group in an attempt to make it more inclusive of the various factions within Iraq.
} 
the final say on government matters. ${ }^{35}$ As noted above, during the days immediately following the regime's fall, it appeared no one was in charge of Iraq-law and order completely disappeared.

Several comprehensive works noted the day-to-day occurrences during the first few weeks in Iraq, but these events were not simultaneously analyzed or compared to previous occupation efforts. Ironically, part of the Consistency problem stemmed from the ease of communication in 2003, vice 1945. It was nothing to pick up a phone or send an email in Baghdad and update Washington on the daily goings-in and receive guidance on next steps; in Germany and Japan, however, troops in local garrisons found themselves largely on their own. MacArthur relied heavily on his "motorcycle diplomacy" to spread word of orders and new developments, but there was no one watching over the shoulders of local commanders. With less likelihood of higher-headquarters interfering, or changing policy to meet a more over-arching need, townships and provinces worked towards their reconstruction without much concern as to other parts of the country. In Iraq, it appears the few orders disseminated often conflicted, or countermanded steps already taken by local authorities (and it was much harder for those local authorities to ignore them). Without clear guidance from the beginning-or even a clear national authority-each regional commander had no choice but to fall back on a hodge-podge of plans and strategies. Then, when the CPA attempted to consolidate these efforts to normalize results, it naturally undid a lot of well-intentioned work and left the Iraqis confused and frustrated. It was clear the Americans were not communicating well with another, despite their technological advantages, but it was not clear who was really in charge: the U.S. soldier leading the armed battalion down the street, or a faceless entity in Baghdad that kept changing.

In 1945, despite serious initial resistance from the War Department to the idea of a long-term commitment, there was never any question of ending the occupation and transferring power to the

\footnotetext{
${ }^{35}$ What is interesting is that-in all three cases-the President made it clear who he appointed: Clay, MacArthur, Bremer. Only Bremer seemed to have authority problems, however; whether these were based on actual competence or lack of military position is an area of future research.
} 
Germans until conditions had stabilized and the country was no longer a threat to international peace. Yet in Iraq, initially the Defense Department clearly expected to transfer power rapidly. This strategy may have been unrealistic in terms of securing Iraq's cooperation and stabilizing the country, since it relied on continued use of structures associated with Saddam Hussein's tyrannical rule. Once deBaathification policies were implemented, these structures were hollow. Objections from the State Department and the National Security Council seem to have played an important role, as did the political undesirability for a long-term occupation with a presidential election on the horizon. (Maulucci, 2008: 127) By the end of the first month of occupation, Iraq had already experienced two different provisional governments, each with a radically different approach to controlling the country. Perhaps most shocking in the lack of Consistent Iraqi governance is the fact numerous contingency plans were drawn up to prepare for humanitarian disasters, but no one thought such an extensive breakdown of law and order was possible. This was the major argument put forth for the shift from Garner's ORHA to Bremer's CPA; however, had there been a humanitarian crisis on the scale U.S. officials imagined, it is hard to believe a subsequent breakdown in social structures would not have followed. Starvation, chemical weapons, and rampant disease do not breed calm and rational citizens. Which begs the question: why did the U.S. not prepare for both? This question has been unexplored in research to date.

Again, U.S. officials obviously had control over the governing of all three nations. In Germany, they installed local authorities quickly; in Japan, MacArthur used the emperor as a unifying force. In Iraq, neither approach was taken. While previous works have focuses on the consistency of authority before, during, and after conflict, this work serves to illustrate authority can change at the start of an occupation (as Germany illustrates), but then the occupied citizens must clearly understand who is in charge, and frequent changes or overhauls in that system will only breed chaos and apprehension towards the entire effort. 


\section{Security}

In a post-conflict situation, the establishment of a secure environment is generally considered paramount to the successful reconstruction of a country (Jones, et al, 2005: xxv). Case after case of failed democratization in the post-colonial world has shown order is prior to liberty. Democracy cannot flourish in a context of chaos; before it can emerge, you must have a state of law, with effective institutions that can deliver fair, predictable order to citizens (Bellin: 599). This is perhaps the clearest and most obvious difference between the post-World War II occupations and Iraq.

\section{Germany}

Despite attempts by then-National Security Advisor Condoleeza Rice in 2003 to equate violence by Iraqi insurgents with Nazi werewolves, the American military occupation of Germany did not encounter any serious armed resistance. The fact that Nazism had been discredited in the eyes of most Germans played a major role in this. The massive drawdown from 1.6 million troops in the American zone to only 200,000 troops between 1945 and 1946 had no significant impact on the security situation. (Maulucci: 125) When the United States entered Germany on September 11, 1944, military governance units followed on the heels of combat troops and established security and authority in each population center within the U.S. sector. By May 1945, the occupation of Germany was complete. (Jennings: 9) In regards to the actual experience on the ground, according to an official report from troops in the town of Osnabruck,

"The Military Government detachment got in early, being sniped at on the way in. They surveyed the local Nazi party HQ and occupied it. They found civilians and displaced persons engaged in looting...two officers of the Detachment tackled the crowd with their revolvers and gained control after inflicting casualties. The commander of the detachment then reinstated 24-hours house arrest for the entire population and gained control, which he has not again lost..."

(Barnett: 14) 
Unlike in Iraq, there was a concern from the outset about preventing a security vacuum in Germany. The German military was defeated, but it needed to be disarmed and demobilized promptly and efficiently. As part of that process, Nazi war criminals needed to be identified and brought to trial. In addition, the Allies feared renegade guerilla groups of German military forces would reform into small units and launch attacks against Allied forces. Consequently, the first order of business for the occupation was to establish security for the military governments. This required, at least initially, a robust presence throughout the country. At the same time, however, there were tremendous external pressures on the United States and other Allies to withdraw their forces as soon as possible. The need to shift forces to Asia to finish the war against Japan and the domestic cry to "bring the boys home" created enormous pressure on U.S. forces to withdraw as soon as the fighting stopped. (Dobbins, et al: 9)

For six months after the surrender, U.S. occupation forces in Germany utilized the German army for policing and labor duties (Fischer, 1968: 322-24; Ziemke: 294, 388-89). The use of German troops provided continuity and made for a peaceful reconstruction period. General Lucius Clay, the officer chosen to lead the occupation effort, was prepared for the worst, and he had what Paul Bremer did not: an adequate number of troops. (Weiler: 13) After five months of occupation, the German civilian crime rate was almost disconcertingly low. In October, the Army believed there must be a "simmering cauldron of unrest and discontent" within the country. The only disturbances were black marketeering, some thefts of food and firewood, and petty violations of military government ordinances. Patrols would occasionally find decapitation wires stretched across the road (ineptly, it seemed, since no deaths or injuries ever resulted from them) and public safety officers from scattered locations reported antioccupation leaflets and posters, as well as threats against German girls who associated with U.S. soldiers. Though there were isolated attacks on the troops, many commanders reported there had not been a single assault on their personnel in more than four months. (Ziemke: 354-55) 
As a way to meet the U.S. sector requirements while still reducing the troop levels, in the fall of 1945, U.S. military leaders began to consider adopting a constabulary, police-type force in Germany using occupation troops. The purpose of the constabulary force was to fill the law-and-order gap with U.S. personnel until a professional German police force could be trained. At first, commanders in Germany objected to this approach as inefficient and impractical, but intervention by Generals Marshall and Eisenhower overcame these reservations. (Id: 10) The constabulary was planned to be a mobile reserve force that could respond to incidents of civilian unrest, conduct mounted and dismounted patrols, interdict smuggling operations, and assist in intelligence gathering (Carafano, 2002: 75). The planned force of 38,000 was calculated on the basis of one constabulary soldier per 450 Germans ${ }^{36}$ (Ziemke, 1975: 334-35; 339-41). The constabulary force was established in January 1946, less than nine months after cessation of hostilities. A school trained soldiers for these duties, with troops receiving lessons on law enforcement and military government issues. The constabulary peaked at only 31,000 troops, but it played an effective role in the U.S. sector, despite significant personnel turnover resulting from rapid demobilization. The constabulary's troop strength remained constant, even as overall troop strength dropped to around 200,000 (Snyder, 1947: C-3), thus ensuring adequate forces remained to maintain law and order until the Germans could do so themselves.

Japan

At the time of its surrender, Japan had mobilized between 3.6 million and 4.3 million troops to defend against an Allied invasion, and they were all still armed. Army intelligence estimated an additional 3.5 million troops were dispersed throughout Japan's former empire, including 1.6 million in Manchuria and China (MacArthur, 1966: 752-53), and it was unknown whether all would comply with the emperor's order to surrender. $97 \%$ of Japan's stock of guns, shells, explosives, and other military

\footnotetext{
${ }^{36}$ There were approximately 16 million Germans in the American sector.
} 
supplies were thoroughly protected in underground storage depots not vulnerable to air attack (Pacific War Bombing Survey, 1946: 25).

Occupation officials aimed for the total and permanent demilitarization and disarmament of Japan, both materially and ideologically. Dismantling of war-making industries was a top priority, even though securing the economy was viewed as essential to domestic stability. All institutions of expressive militarism and aggression were suppressed. (Bridoux: 130) U.S. forces conducted foot and motor patrols while intelligence and inspection teams searched for concealed arms and ammunitions. Inventory and disposition teams were established to evaluate, inventory, and-where appropriate-destroy captured weapons and equipment. The Japanese, under U.S. supervision, actually handled the disposition themselves, dumping ammunition into the sea and cutting equipment and other materials into scrap metal before turning it over to the Japanese government for other use. (Dobbins, et al: 34) Though the police had been decentralized, leaving Japan without a domestic force capable of responding to largescale internal unrest (Id: 42-43), there were more than sufficient numbers of U.S. troops to secure the nation, and the means of resistance was quickly removed.

Thus, in post-World War II occupations, the U.S. had a sufficient number of troops capable of establishing a strong, military presence in every population center. Both Germany and Japan still possessed the means to continue fighting, but occupation troops secured those weapons quickly and prevented them from falling into the hands of those who would promote civil unrest.

Iraq: Missed Opportunities

In its early months the stabilization and reconstruction of Iraq did not go as smoothly as expected. There was, in fact, no security for Iraqis under the occupation, and that antagonized them. They would read about a U.S. soldier who died, but never about the kidnappings, robberies, and rapes of citizens. The average housewife was terrified, and U.S. forces were being thwarted at every turn. (Ricks, 
2007: 326) During the 1990s, the U.S. made major investments in the combat efficiency of its forces. The return on investment was evident in the dramatic improvement in war-fighting demonstrated from Desert Storm to OIF, but there was no comparable increase in the capacity of the U.S. armed forces or civilian agencies to conduct post-combat stabilization and reconstruction operations. (Dobbins, et al: 220)

In part because of the poor quality and sheer lack of qualified CPA personnel ${ }^{37}$, the U.S. occupation authorities would prove unable to adjust their stance when their assumptions about postSaddam Iraq proved wrong. The immediate manifestation of this failure was the inability to establish order on the ground after the regime was toppled from power. In the days and weeks that followed, Iraqis -in both spontaneous acts and well-orchestrated assaults-attacked and ransacked virtually every significant public building in Baghdad, while also ravaging other cities. As Ambassador Peter Galbraith, U.S. advisor to the Kurdistan Regional Government, would later explain to a congressional committee, "In the three weeks following the U.S. takeover, unchecked looting effectively gutted every important public institution in the city-with the notable exception of the oil ministry," because it was the one secular structure American troops defended. What Iraqi's saw, a Shiite cleric explained, was the Americans protecting oil, and nothing else. The economic cost of the looting was estimated at \$12 billion, not including future costs in delayed reconstruction and the political price of having Iraqis equate freedom with disorder and violence. (Diamond: 282) As a result of the chaos, the CPA was unable to

\footnotetext{
${ }^{37}$ This issue is discussed in detail in Chapter 5's Approach to Civil Affairs section. Generally, after the 1950s, civil affairs in the U.S. military became a mission to work with existing governments, with little attention paid to circumstances where no functioning government was present. By 2000, the Army's basic manual dropped all reference to military government and the loss of the doctrine was complete. (Keifer: 18-19) Occupation staff were selected based on their direct skills, with little to no training on how those skills transferred to establishing a new government. CPA administrators rarely traveled outside the heavily fortified "Green Zone" due to a shortage of security personnel and military escort vehicles. Many State Department personnel were still in their twenties, but placed in charge of projects such as Coordination of Local Governments for Northeastern Iraq. (Mansoor, 2009: 27) Still others were in positions only somewhat relevant to their previous expertise, such as the manager of a fastfood chain contracted to run the new small business owners association in the southern provinces (Van Buren, 2011). Turnover was also exceptionally high, with most civilians staying in-country less than three months.
} 
provide even the most basic services, such as electricity, clean water, and security, to the Iraqi population. By the fall of 2003 , the occupation was starting to lose what little lukewarm support it had. (Ricks, 2007: 108)

Saddam Hussein's Iraq was armed to the teeth, and virtually every able-bodied Iraqi male was trained in the use of small arms. In bunkers across the country, there were tens of thousands of tons of conventional weaponry-mortar shells, rocket-propelled grenades (RPGs), rifle ammunition, explosives, and so on. U.S. commanders did not disturb these weapons caches out of fear they might be boobytrapped with biological or chemical WMD. The bunkers were often bypassed and left undisturbed by an invasion force already stretched thin, so the insurgents were able to arm themselves at will. According to one assessment, "Iraqi civilians may have gained control of seven to eight million small arms." (Small Arms Survey, 2004; Record, 2007: 71) Thousands of weapons experts, translators, and other specialists, along with their support personnel, were working to find unconventional weapons that did not exist, and soon were being attacked with conventional weapons ignored by U.S. officials. (Ricks, 2007: 145-46)

The insurgency also had, in former Baathist operatives, a considerable body of technical and engineering expertise, which-together with jihadist volunteers-permitted it to develop and perfect improvised explosive devices (IEDs), used primarily as roadside bombs, and suicide car bombs, employed against softer-and mainly Iraqi-targets. There were not nearly enough troops to secure Iraq's long, porous borders. Had Iraq possessed WMD as the Bush administration so loudly asserted, U.S. forces might well have failed to prevent them from being spirited out of the country. (Record: 71, 111)

A first taste of what lay ahead for the Americans came just over one day into the war, on March 22,2003 , when a platoon sergeant for the $3^{\text {rd }}$ Infantry Division was looking out of a tank and waved at a group of Iraqis in civilian clothing. Instead of waving back, they began attacking the convoy with AK-47 rifles, RPGs, and mortars, riding at the tanks in pick-up trucks. Another vision of the future came a few days later, when four U.S. soldiers were killed in the first suicide car bombing of the war. The 
expectation that Iraqi commanders in the south would surrender, and even bring their forces over to the side of the Americans by the thousands, proved wrong; not one commander did so. (Ricks, 2007: 118)

The dissolution of the country's defenses through de-Baathification and disbanding of the military $^{38}$ degraded the Iraqi immune system to outside influences. Global extremist groups provided the myth the real reason the Iraqi army was dismantled was to keep Arab countries weak and Israel strong. Others commented the United States was only interested in Iraq's natural resources and had little concern for the security and survivability of the country. The coalition and reconstruction teams did little to dissuade these thoughts; they allowed the looting to occur, security to evaporate, and the government to be fired. Nationalists feared what would become of their country, and history demonstrated this had happened before. The conditions were ripe for an insurgency, and without the border secured, fellow Muslims infiltrated to assist. (Weiler, 2009: 15) Once the formal conflict was over, jihadists began pouring into Iraq, making it more vital to U.S. national security than was true before the war (Diamond: 6). The security situation worsened due to the rise of former regime loyalists and various militias opposed to the American occupation. Far from being destroyed in the war, paramilitary units faithful to Saddam had been dispersed instead of eliminated. They quickly reorganized and joined with anti-occupation forces to start a guerilla war. (Rathmell, 2005: 1024; Hendrickson and Tucker, 2005: 18-21)

Iraq: Summer 2003

On June 19, 2003, Deputy Secretary of Defense Paul Wolfowitz testified on Capitol Hill the situation in Iraq did not qualify as a war: "I think it is worth emphasizing that these guys lack the two classical ingredients in a so-called guerilla war, if that's what you want to say they are conducting. They lack the sympathy of the population, and they lack any serious source of external support." He was

\footnotetext{
${ }^{38}$ This process is discussed in detail in Chapter 5's Policy Decisions section.
} 
wrong on both counts: Iraqi sympathy for anti-American forces was growing and external support was coalescing. Many top Iraqi Baathists had taken refuge in Syria, sending money and fighters back into Iraq and receiving aid from supporters in Saudi Arabia, other Gulf States, and elsewhere in the Arab world. Some Shia groups also had strong ties to Iran. (Ricks, 2007: 170)

In midsummer, the insurgency began to erupt, with a series of bombings in Baghdad and widespread small arms attacks on U.S. patrols. By early July, electricity blackouts returned and anger with the U.S. occupation rose. The military found itself facing a much more entrenched enemy than it anticipated. Increasingly, America's top generals in the field were acknowledging this while their Iraqi allies were making dire warnings of more trouble if the American presence crystallized into a long-term occupation. A Pentagon advisory council reported the war had entered a new phase of active resistance. (Diamond: 42) Due to continued personnel losses, three months after the fall of Baghdad, it was still unclear whether the United States and Britain were truly in the conflict termination phase and moving towards nation-building, or whether they were moving towards low-intensity conflict (Cordesman, 2003).

The real war to determine the future of Iraq began in early August, when a car bomb exploded outside of the Jordanian embassy, killing 11 and wounding more than 50 . The initial focus of the attacks was not the United States, but their allies perceived as legitimizing the occupation. Then, on August 19, a cement truck laden with artillery shells and other explosives crashed into the headquarters of the United Nations in eastern Baghdad. The explosion destroyed a corner of the three-story building, killing 22 and wounding 70. Sergio de Mello, a Brazilian diplomat who had worked in humanitarian and political programs with the UN for 34 years, had come to Iraq as the UN Special Representative to advise on the occupation. He and many of his top aides were among those killed in the attack. The effect was devastating -in the attack's wake, the UN began to cut its presence in Iraq, from 800 staffers to 15. It would be several months before the UN agreed to send another emissary. This was crucial because the 
UN had served as a bridge for the U.S. to certain Shiite leaders who would not acknowledge the occupation by meeting with CPA officials directly. Other international organizations began to pull out in the following weeks, including the World Bank, the IMF, and several relief agencies. (Ricks, 2007: 176, 215-16; Diamond: 46, 57)

In addition to these high-profile terrorist bombings, there was a steady stream of small-scale assaults on police stations and other facilities, including another small bomb against the UN in September. There were also exceptionally high levels of crime, with the murder rate in Baghdad about ten times that of Washington, DC. The attacks grew both more numerous and more sophisticated during Ramadan, starting on October 26. In the summer there were about 10 to 15 assaults on U.S. soldiers every day; by mid-October, the number had climbed to 45 . Also, for the first time, the insurgents had success attacking aircraft. In early November, a succession of car bombings and assassinations killed and terrorized Iraqis cooperating with the occupation. The newly recruited Iraqi police were besieged, grossly lacking in cars, guns, equipment, body armor, and were becoming a particularly popular and easy target. (Diamond: 46-47, 50; Ricks: 248)

The political effect of the insurgency was a wedge between the occupation authority and the Iraqi people. Due in no small part to the security situation, both Garner's and Bremer's staff remained isolated in their headquarters, which quickly gained the label, "Emerald City" or "Oz" 39 (Maulucci: 126). Dealing with the rise of armed militias was paramount to security. The failure of the CPA and coalition to train and equip new Iraqi Security Forces proved lethal to many reconstruction projects. Major efforts were called off and others were delayed; hence, the hope of relying on some form of improvement in the daily life of Iraqis in order to manufacture consent to the occupation remained elusive. (Bridoux:

\footnotetext{
${ }^{39}$ In the military "green" is an indicator conditions are good. The "safe zone" surrounding occupation headquarters, located in Saddam's former Presidential Palace, was officially referred to as "the Green Zone".
} 
105) The violence also further depleted Iraq's educated middle class and left bitterness and deeper divisions of identity and outlook (Marr: 258-59).

Yet, the failure to address the security deficit persisted. When faced with a growing insurgency and lacking the troops to maintain order, with Iraqi confidence in the CPA plummeting, and with foreign fighters pouring across unsecured borders, Secretary Rumsfeld and other senior officials insisted there was sufficient military presence. In reality, the insufficiency of the forces and resources meant roads were unsecured and both coalition workers and cooperating Iraqis were unprotected. There were not enough troops to protect public buildings, streets, and weapons depots; to hunt down the remnants of Saddam's forces; to seal the borders; or to establish decisive authority. (Diamond: 288)

Iraq: Indigenous Security Forces

Especially worrisome was the sluggish pace with which the U.S. was outfitting and training Iraqi police and soldiers, which lay at the core of U.S. strategy. Ten months into the operation, there was not a single properly trained and equipped Iraqi security officer. There were more than 10,000 police and civil defense officers on the rolls, but none had received anything more than ad hoc training ${ }^{40}$ and rudimentary equipment. The training program had been handled in a way that, like so many other early policy decisions in Iraq, ignored the lessons of history. U.S. Special Forces units specialize in training foreign militaries as much as anything else, but both Garner and Bremer decided to have the training of Iraqi Security Forces (ISF) conducted by contractors and augmented by regular soldiers, including reservists and members of the National Guard. As justification, administration officials pointed to manpower concerns, saying Special Forces should not be "wasted" on training. However, such training is not just a matter of military knowledge, but of cultural understanding and skill at being able to operate

\footnotetext{
${ }^{40}$ The recruitment and training of new Iraqi security forces is detailed in Chapter 5's Approach to Civil Affairs section.
} 
within a foreign culture while producing cohesive units that are not only trained but willing to obey commands. (Ricks, 2007: 328-29)

Reorganizing the Iraqi forces was painstakingly slow due to absence of training, ignorance of human rights, and lack of initiative, equipment, and professional standards (CPA 2003u: 4; 2003s; 2003t; Executive Office of the President, OMB 2003b: 4). The Iraqi Civil Defense Corps (now merged with the regular army) was set up to handle Iraq's internal defense, but it did not have sufficient manpower or training to deal with an insurgent enemy armed with machine guns, RPGs, and mortars (Record: 93). By early December, it was clear the training of the new Iraqi army was going badly. More than half the recruits in the first trained battalion deserted while on leave. At the CPA, officials began to write off the entire program. (Ricks, 2007: 329) When attacks began to increase in the spring of 2004, many Iraqi forces ran from the fight (Id; Record: 93).

Less often spoken about was the distrust many U.S. officers developed towards ISF members. It was believed many of the Iraqi officers were in league with the insurgency, or at the very least were so fearful they cooperated with it. One Marine officer stated, “Any Iraqi officer who hasn't been assassinated or targeted for assassination is giving information or support to the insurgents. Any Iraqi officer who isn't in bed with the insurgents is likely already dead." (Ricks, 2007: 341) Blurred loyalties, provision of inadequate equipment, and concerted attacks on the police led ISF to collapse in several cities. Almost 3,000 officers left the rolls the week of April 17, 2004. At about the same time, 12,000 troops deserted the Civil Defense Corps. By the end of the CPA's tenure, the prospects of Iraq shouldering the security burden looked bleak. Not only were their numbers low, but the quality of the Iraqi forces was questionable (DoD, 2004: 21; Ricks: 341). Due to a lack of training, delays in delivery of equipment, and poor leadership, ISF were never a match for heavily armed insurgents (GAO, 2004: 57-9; U.S. Dept of State, 2004). 
Iraq: The Public Relations Problem

The U.S. fared no better in terms of winning the hearts and minds of the population. At local levels, policing fell to U.S. combat forces untrained and unprepared for such action. Increasingly, they used harsh tactics, often treating the public in humiliating ways offensive to the local culture, thereby raising-rather than reducing-tensions. Iraqis found it hard to believe the U.S. could be so unprepared or inept, and it must be a deliberate attempt to extend the occupation of the country. The Iraqi people's loss of confidence in the U.S. and the resultant loss of momentum directly contributed to the growth of the insurgency. In November 2003 , only $11 \%$ of respondents said they would feel safer if the U.S. forces left Iraq immediately; by January 2004, that figure had more than doubled, to $28 \%$. In April, it would be $55 \%$. As the pollsters put it, Iraqis had come to see the U.S. military as part of the problem, "a liability whose presence makes things more dangerous". U.S. forces operated from large base camps and conducted operations in populated areas, but generally did not maintain a long-term presence in society. The occupation devolved into a game of "whack-a-mole", where U.S. forces would secure an area only to have another hot spot pop up. Forces would then leave the secure area to respond to the new threat and insurgents would re-occupy the previously secured area. (Keifer: 26; Ricks, 2007: 170)

The inability to maintain security led to the rise of militias supported by the people. These groups were dominated by sectarian elements and it was only a matter of time before there were clashes among the religious groups. Militias intimidated the local population, but often provided the only security mechanism (Marr: 268-69; Ricks, 2007: 156), much like Saddam's henchmen during his reign. ${ }^{41}$

Travel was becoming more and more dangerous, and while British civilians were issued and required to wear the highest-grade of personal body armor, most of the CPA staff had only sub-standard

\footnotetext{
${ }^{41}$ Not a single suicide attack was conducted in Iraq during the 25 years of Baathist rule, even though al Qaeda and other Islamic groups considered Saddam's secular state an apostate regime. (Merom, 2003: 44-45)
} 
equipment. On March 9, 2004, the first two CPA civilians were killed in Iraq by individuals posing as police officers. A few days later, Bremer issued a memo cautioning CPA employees to vary the times and routes of their travel and requiring all travel outside of the Green Zone be during daylight hours in a two-vehicle minimum convoy. As a result, most CPA travel outside of the Green Zone was halted (Diamond: 180-81), further deepening the divide between the occupiers and the occupied.

It has been said U.S. operations against insurgents in Iraq put too great an emphasis on destroying insurgent forces and minimizing U.S. casualties and too little on providing security to the Iraqi people. There has been much written about the CPA's lack of strategic communication, but they communicated some points all too well. The Green Zone had security and services-basically, everything the Iraqis wanted. A lot of people had no electricity, but could look across the river and see the CPA lit up at night. That was how the CPA truly communicated its priorities to the people it claimed to be protecting. (Record: 126; Ricks, 2007: 326)

\section{Summary}

What seems to have been recognized in post-war Germany and Japan but ignored in Iraq is easily summed up by retired Colonel John Warden, one of the U.S. Air Force's most brilliant strategists: "The biggest risk by far is in the post-war period. When the British took over after World War I from the Ottomans, they found themselves being assassinated from almost the first day and saw the whole area in rebellion within a year." To deal with these threats, a rapid reconstruction of Iraqi forces might have alleviated the security burden for coalition forces and generated some consent among the Iraqi population, as it did in Germany, where enemy troops were used to patrol the streets. This would also have allowed coalition forces to adopt a lower profile. Instead, the reformation of ISF lagged considerably, with the consequence of coalition forces shouldering the bulk of the fight and losing the opportunity to legitimize and empower Iraqi forces and government officials. Any Iraqi actor aspiring to 
play some role in his nation's future had to be backed by an armed organization, leading political parties and religious and ethnic groups to form their own militias in order to support their claim to power (Bridoux: 101).

In Germany and Japan, Americans lived and worked side-by-side with the local citizens, not in secure zones behind concrete barriers with armed guards. They did not tolerate threats to the population's security because they were part of the population-local security was their security. In contrast, American soldiers in Iraq were segregated, and it was easy for them to retreat behind the walls when the bullets started flying, and even easier to claim they couldn't do their jobs (in a war zone) because it was too dangerous. The collapse of public order in Iraq at a level not seen in Germany or Japan, despite far greater logistical and humanitarian challenges, had a devastating and long-lasting effect. It undermined Iraqis' confidence in the United States, fanned suspicions the U.S. did not want a strong Iraq, opened vast borders to infiltration by extremists and other malevolent forces, left Iraq's immense store of arms unprotected and ripe for the picking, and provided an opportunity for every opponent of democracy to use Iraq as an example of its damaging effects. Moreover, the chronic disorder made it nearly impossible for U.S. forces to carry out reconstruction efforts, creating a selfperpetuating spiral of events that led nowhere.

Security could have lagged in the beginning, but quickly brought to bear if the right procedures were put in place; all-around, however, the plans for securing the nation were overlooked in Iraq. At their lowest point in Germany, troop levels never dipped below 200,000, and this was only after significant drawdowns; in Iraq, they never exceeded 160,000, and that number was not reached until the troop surge in 2007. In Japan and Iraq, U.S. officials knew there were large caches of military weapons hidden throughout the country. Marines quickly scattered throughout Japan to locate and secure these depos; in Iraq, they were left to be used against coalition forces by a variety of armed groups. (Sadly, these weapons could have been used to arm the woefully under-supplied ISF.) The 
theory behind this decision was the Iraqis would be so pleased to have the U.S. as their liberators they would not see a need for violence. This is hard to rationalize with the theory Iraq was the center of the war on terror, and likely had individuals willing to take advantage of the situation. Even within U.S. territory, government weapons of this kind are safely guarded, not left available to the masses.

Another problem in Iraq was the reliance on outdated intelligence. It is amazing that in the presence of $21^{\text {st }}$ century capabilities, the U.S. military had little clue what was happening inside the country. There were intelligence gaps in World War II, of course-mainly, the mistaken belief regarding the redundancies in the German power grid-but those are far more understandable. During World War II, the Allies also realized they needed up-to-date knowledge, and did not rely on facts ascertained more than twenty years prior. In 2003, Pentagon and State Department officials used circa-1991 data to determine Iraqis in the south would rally behind American troops, disregarding the decades of sanctions and the sense of abandonment those individuals had experienced in the interim.

Poor training - both in substance and approach—only contributed to the security problem. For some reason, CPA officials believed quickly trained and poorly equipped Iraqi troops would be able to secure the country, when the U.S. military could not do so. Bremer repeatedly asserted he had little to work with, since the Iraqi military and police force simply 'went home'; however, there was no effort at the beginning of the occupation to recall these troops, secure them in barracks, or even communicate to them they could return to work. Instead, the CPA decided it would be too hard to track everyone down, and decided to rebuild the entire defense institution from the ground up. The Iraqi army, it would seem, was a group of highly-micromanaged individuals who suddenly found themselves with no boss; therefore, it is likely they would have responded to a strong leadership presence who gave them a mission to fulfill. In the least, this would have prevented them from re-arming from the weapons caches and possibly given coalition troops time to properly secure more population centers. 
The training of Iraq's new security forces was performed by groups arguably the least proficient in such tasks: private contractors and army guardsmen and reservists. Neither of these groups conducts military training on a large scale; contractors focus more on individual security, similar to bodyguards, and most soldiers perform their assigned job specialty, not train others to be soldiers. It would have been far more beneficial to rely on actual military training instructors, which are extremely limited in number, or use Special Forces, but this was seen as a "waste" of their talent and skills. Ironically, however, this is one of the skills SF troops are specifically trained for: training and working with foreign militaries. If the violence was purged through a well-trained Iraqi army, SF soldiers would not be needed for covert operations, so the problem would resolve itself. Instead, contractors and reservists (who were likely resentful towards Iraqis they viewed as the reason for their mobilization) were used, to ill effect.

Finally, there seemed to be a great reluctance to endanger lives, despite repeat assertions that the operation in Iraq was a war. War is messy, war is dangerous, and the CPA's inability to accept this caused them to behave far too cautiously. In Germany and Japan, soldiers lived alongside local citizens. They did not wear body armor when they walked down the streets, they rode motorcycles throughout the countryside, and they interacted with the population every day. But in Iraq, if a reconstruction project was deemed too dangerous, it was abandoned, despite the dire need to bring basic services to the population. If there was risk a government worker could be attacked, he was recalled to the capitol. If it was not safe to live among the people, the soldiers retreated behind concrete barricades. Following the first bombing, every major aid organization withdrew. Part of this caution was due to the use of civilians for most reconstruction efforts, rather than military troops. Civilians are universally viewed as "not having accepted the risk" of putting their lives in danger, regardless of the location. Thus, it was easily accepted work would stall every time the threat of danger arose. Yet Bremer never declared martial law or instituted curfews; there was not a soldier on every street corner. Civilian contractors 
were repeatedly recruiting for reconstruction projects, rather than using soldiers directly, as in Germany and Japan. Coalition forces stayed safely behind their walls and let the country descend into anarchy.

Most works acknowledge troops levels in Iraq were too low; even during the surge of 20072008, they did not reach 1945 levels. But even the troops that were present in Iraq in 2003 were utilized poorly, and this trend continued throughout the CPA's rule. But the many sources cited above provided only on-the-ground observations of the happenings in Iraq, with little to no comparison to lessons learned from previous occupations, or rationale as to why those lessons were not followed. As the next chapter illustrates, the CPA never appreciated no decent work towards a democratic transition could be accomplished without security, even thought this fact is fundamentally accepted by nearly all political science scholars. The on-the-ground observers lamented a great deal about the difficulties faced in trying to implement a new Iraqi government (See, infra, Diamond, Van Buren, and Ricks). But while work was stalled or delayed, the money kept coming to fund hundreds of civilian-led projects, money that would been better served put towards bringing more military troops into the area, or providing decent training for the Iraqis.

\section{Civil Institutions}

Germany and Japan emerged from World War II with meritorically organized, rule-bound state institutions intact. Both possessed an effective police force, judiciary, and civil service with which to govern. Germany, after all, had been the paradigmatic bureaucratic state, and the Nazi regime did not dismantle this, but rather ruled through it. Once the war was over, these state institutions were there to be mobilized by the occupation forces, after limited de-Nazification. Similarly, in the case of Japan, the country had a strong state bureaucracy that survived the war and was immediately available for mobilization by the occupation forces. These forces seized upon this resource because the Americans 
were woefully under-equipped with proficient Japanese speakers and could not run the country on their own.

By contrast, it was popularly believed Iraq was sorely lacking in effective, meritorically organized, rule-bound state institutions. The state under Saddam was patrimonially organized, rife with corruption, and driven by politics and loyalty tests, rather than merit. As a result, it was decided to rebuild many key institutions from scratch, especially the police and the judicial system, rather than utilize the already-existing agencies. (Bellin: 598-99) But this is not to say the obstacles encountered in Germany and Japan following the end of armed conflict were easy; in fact, the challenges in reinstituting a civil society seemed, at times, to be nearly insurmountable.

\section{Germany: Nutrition and Health Concerns}

As early as June 1945, one Army group reported the Nazi party seemed "almost to have vanished from the earth". Army services had arrested the most prominent and dangerous Nazis by the thousands $-50,000$ by the end of the month. Going forward, the Potsdam Conference declared "all democratic parties with rights of assembly and public discussion shall be allowed and encouraged throughout all Germany". In the U.S. sector, policy focused on a grassroots approach designed to build a German civil society from the bottom up. Political parties were initially limited to the county level and later authorized at the state level. (Ziemke: 277; Dobbins, et al: 15) But, as occupation forces would quickly realize, the population within the zone faced far more demanding problems in the short-term than rebuilding a political society. With the unconditional surrender of the German armed forces on May 7, 1945, the Allied high commands became responsible for the welfare and governance of a Germany now utterly devastated by strategic bombing and ferocious land battles. The population literally faced famine, as well as a swelling tide of diseases, such as typhoid and typhus. Malnourished children were especially vulnerable to diphtheria. (Barnett: 1) 
In addition to its own population, the nation was awash in refugees, the scope of which is hard to overstate. The Inter-Allied Committee reported in mid-1941 there were 21 million displaced persons in Europe. During the war, millions of non-Germans were brought to Germany as forced laborers. This situation worsened during the last years of the war as millions more people fled in the face of German scorched-earth withdrawals or in fear of Soviet military retribution. Moreover, the Soviets and other states were eager to expel ethnic Germans from their countries. Many of these refugees and displaced persons had no homes and no means of support. Native Germans, meanwhile, were facing massive food shortages and deprivations as economic activity ground to a halt after Allied forces invaded. It was a humanitarian and refugee crisis of unprecedented magnitude. (Marrus, 1985: 296-99)

Because the German government was in no position to provide aid, humanitarian assistance to refugees in Germany was coordinated and financed through occupation forces. However, private relief organizations, such as the International Red Cross and religious organizations, were heavily involved in the actual provision of food, clothing, and health care, as well as in assisting refugees and displaced people with finding surviving friends and family members. They also assisted with emigration or moves to new locations. The U.S. government provided support for these activities in the American zone through the Governmental Aid and Relief in Occupied Areas (GARIOA) program and through grants of surplus war supplies. (Killick, 1997: 76) Not easily understood was the Germans' apparent indifference to the suffering of their fellow countrymen. In May of 1945, a few Catholic priests were the only ones doing welfare work among the refugees. Occupation officials observed no civic organizations had expressed the slightest concern for the concentration camp victims and no voluntary offers of food, clothing, or medical aid had been made.

After V-E Day, SHAEF (Supreme Headquarters - Allied Expeditionary Force) officials estimated the total number of displaced persons (DPS) in SHAEF-held territory-including those already repatriated-to be 5.2 million. The western Europeans were leaving as fast as transportation could be 
provided, at a rate of 200,000 a week in May. In June, the rate of Soviet DP repatriation reached 250,000 per week; as of July 1, more than 1.3 million Soviet citizens had moved back east, but there were still 700,000 Soviet citizens and 871,000 Poles, now the largest DP group, in the country. SHAEF was also dealing with five million prisoners of war and disarmed enemy troops, nearly three million of which were in U.S. custody. (Id: 292-93)

The western sections of Germany were having to feed populations swollen by refugees. The large city populations were often half of normal, but the rural towns and villages had as many as two and a half times the usual number of people. The relocation of displaced persons cut the farm labor force in half ${ }^{42}$; the bombing destroyed processing machinery and impaired the distribution system; and, because the fighting prevented the movement of grain during the previous winter, western Germany began the year with a food shortage. The requirements to feed Germany would be large: total agricultural output from the U.S. sector would only be enough to supply 938 calories per day to the normal consumer. Normally, the occupied area was only 60 to $70 \%$ self-sufficient; the difference had come from imports and from eastern Germany, which was now in Soviet hands. SHAEF predicted sporadic starvation in urban areas before the harvest unless food was imported. (Ziemke: 274-75)

Although the decision was not easy, since all of Europe was short on food, SHAEF began importing 650,000 tons of wheat for Germany in June. In Berlin, after some bridges were reopened and the food trains began running to the cities regularly, the daily civilian ration gradually rose to 1,250 calories. This was more than the Germans in the western zones were getting, but Germans in those zones could sometimes forage in the countryside, trading personal belongings to the farmers for potatoes, eggs, or meat. Berliners had to either live on the daily ration or on the black market. On several occasions, children and older people were observed in parks, gathering grass to eat. (Id: 347-49)

\footnotetext{
${ }^{42}$ Many of these individuals may have been working under slave conditions, though some were simply dislocated from their homes during the war and working as day laborers. Whatever their working conditions, without this labor, farmers were no longer able to produce crops at pre-war, or even wartime, levels.
} 
Military government detachments set up farm machinery and auto repair shops that could make a usable truck out of two or three wrecks. Using central repair and strict surveillance, the army raised the number of vehicles available for civilian transport from 7,500 in May to 25,000 in June. By the end of May, these shops allowed mills to produce 20 tons of flour per day, and one creamery was able to process 50,000 quarts of milk. But these items were nowhere near enough to feed the people in the zone. Eisenhower eventually ruled the occupation force could use imported military government food for the disarmed forces, but this was not a real solution either; there was a food shortage in the United States, as well, and the Army had to reduce officer and enlisted troop rations by $10 \%$ to meet the new demands. Because there was also no provision of clothing or equipment for prisoners, SHAEF quickly issued release orders for agricultural workers, coal miners, transportation workers, women, men over 50 years of age, and others in key occupations. (Id: 274, 293)

Though the Germans were not starving in the summer of 1945, lack of adequate nutrition was likely a contributing factor in many deaths. By the end of August, the U.S. Chief Surgeon reported nutritional survey teams found $60 \%$ of Germans were living on a diet that would inevitably lead to diseases caused by malnutrition. By early autumn, U.S. newspapers were printing stories about the approaching "Battle of Winter", a struggle against sickness, starvation, and cold. The occupation forces figured in some accounts as semi-allies, in others as dispassionate observers, and occasionally as the potential target of the desperate. Allied leaders instructed military government to warn German officials, from the ministry presidents on down, they and their communities would be held accountable for acts against the occupation forces. (Id: 407)

In October, General Clay knew the daily ration would not be enough to sustain life through the winter for those living in unheated dwellings. More to raise morale than out of a belief it would matter, and even though sufficient food did not exist, Clay announced an increase in daily rations to 1,500 calories. To conserve precious calories and provide hot meals to those without fuel to cook their own, 
military government detachments began setting up community kitchens. These kitchens were able to serve more than 4.5 million meals a month. (Id: 351, 409-10)

The harvest, all things considered, had been a good one, but could not-under any circumstances-have been good enough to feed the zone population throughout the winter. In December, the State Department began allowing private U.S. agencies to ship relief supplies to Germany, provided the supplies were distributed impartially to the areas of greatest need. Newspapers gave their readers directions for making briquettes out of industrial ash and clay, which - when soaked in pitch or tar-could be burned to give off a "noticeable amount of heat". Fortunately, the weather stayed warm into the New Year. Because it did, and because the occupation force was able to maintain the 1,500 calorie ration, the Germans began to recover their spirit. Above all, the winter was one of the mildest on record, and the ration held firm. Ironically, the best fed were displaced persons and the interned Nazis: both groups were somewhat overweight, while the normal German consumers were as much as $20 \%$ underweight and showing signs of malnutrition. (Id: 412)

What the average German did not know was the continued ration had no relation to the actual adequacy of food supply in the zone; the situation had actually grown fundamentally worse. By early March, the imported stocks were depleted to the point where they would barely last another 60 days at the current ration level. Things were even worse in the British and French zones. There was now a worldwide food shortage, as the war had converted large, previously self-sufficient areas of Asia and the Pacific into food-deficient areas and reduced European production by an estimated $25 \%$. With almost the whole world waiting in line, Germany would not be fed anytime soon. (Id: 413, 435)

For months, the average German's most pressing concern was food. Occupation officials pleaded with President Truman for shipments of wheat, arguing Germany could not be democratized as long as the people were forced to devote all their thought and effort to the daily search for food. Finally, 83,000 tons of food was delivered, with an almost-equal amount en route. Half of this food, though, was 
Army surplus, scoured from depots around the world, which-while helping to fill stomachs-could not increase the caloric value of the diet as much as an equal amount of grain would have. The crisis was far from over, and, short on fertilizer, machinery, and labor, the zone's agricultural sector was not likely to produce as good a crop in 1946 as it had a year earlier. The unemployed, many of them former whitecollar workers who feared a loss of social status, were refusing jobs as farm laborers. To make matters worse, farmers were hoarding thousands of tons of food to sell on the black market ${ }^{43}$, but since search operations consistently failed to turn up sufficient evidence, occupation officials routinely persuaded themselves the black market was nothing to worry about. Meanwhile, Germany spent the entire first year of occupation rule on the brink of starvation. (Id: 319-326; 437)

Competing with the food shortage for the status of number-one crisis in Germany was the state of coal production. Germans were dependent on coal for heating, electricity, railroads, food processing, and even running water, but much of it was marked for war reparations. At the time of surrender, the production was only $3 \%$ of normal, and most of it was being used just to run the mines. There were over five million tons of coal at the mines, but only enough transportation available to move 19,000 tons a day, so there was barely enough to run the railroads and essential public utilities. Throughout the zone, children were required to bring a piece of firewood with them to school each day to heat the classrooms. (Id: 276, 407-08)

\section{Germany: Refugees and Displaced Persons}

SHAEF also faced further difficult logistical hurdles from 1945-46. As part of the Potsdam Conference, the Control Council agreed to accept more than six million racial Germans who were to be

\footnotetext{
${ }^{43}$ All kinds of goods were available, at astronomical prices, on the black market. Often, they were traded only in exchange for items of value, such as cigarettes, sugar, butter, and coffee. The Germans partly depended on the market for their subsistence and as a means for converting money to materials goods as a hedge against inflation.
} 
expelled from Poland, Czechoslovakia, Hungary, and Austria ${ }^{44}$. They were scheduled to come at a rate of 250,000 per month in December 1945 and January/February 1946, and in larger numbers during the spring. The schedule also called for POWs to be returned to Germany from the United States. Over one million men were allotted to France for rehabilitation work, but the International Red Cross reported in late September that 200,000 of the prisoners already in French hands were so undernourished they were unfit for labor and likely to die during the winter. Eisenhower immediately ordered food, clothing, and medical supplies be provided for the most needy prisoners and stopped all transfers of prisoners to French custody. (Id: 408-09)

At this time, the U.S. forces realized the 350,000 prisoners they still had in labor service units were more expensive than hired civilian labor. Thus, the shipments of POWs coming from the United States were expected to be discharged as soon as possible after they arrived, and the 750,000 prisoners in France were anticipated to be brought back and made a German responsibility. Fortunately, because the U.S. insisted on heated trains for cold-weather transport of Germans expelled from other countries, the expected flood of people from Eastern Europe was kept to a trickle when those nations could not produce proper transport. (Id: 409, 412)

In September 1945, the Army expected the 600,000 or so DPs left in the U.S. zone to be returned home within the next few months. Arrangements had been made to move 6,000 people per day beginning October 1,1945 . However, the Polish government, while propagandizing for a quick return of all its citizens, was actually not capable of receiving the numbers it claimed it wanted. The 57 trains that made the run in October carried far less than 6,000 persons a day, and at the end of the month the Czechs stopped the movements entirely because Poland failed to supply coal. The Poles were

\footnotetext{
${ }^{44}$ The Potsdam Declaration stated, "The Three Governments, having considered the question in all its aspects, recognize that the transfer to Germany of German populations, or elements thereof, remaining in Poland, Czechoslovakia and Hungary, will have to be undertaken. They agreed that any transfers that take place should be effected in an orderly and humane manner."
} 
not going to be sent home as fast as expected, nor was the Army going to be relieved of its responsibilities for them and the other DPs as believed. When London failed to assume supply, equipment, and support obligations for the DPs in October as projected, the Joint Chiefs of Staff (JCS) directed U.S. forces to continue their overall responsibilities for them. (Id: 413)

In the cities, U.S. military detachments moved thousands of Germans out of their homes to make room for the displaced persons, and sick and wounded German soldiers were transferred out of hospitals to provide beds for DPs. The unexpected ending of mass repatriation created the possibility of U.S. troops needing to use force to send the remaining Russians home, since the Soviet DPs were most likely those who demonstrated they were not open to persuasion or ordinary intimidation. Legally, the U.S. command regarded itself as obligated to return the Soviet citizens ${ }^{45}$, and on political grounds it did not see how the eventual use of force could be avoided; but in the minor disturbances that had already occurred, U.S. troops sympathized with the demonstrators. Forced repatriation was likely to provoke downright refusals to carry out orders. (Id: 285,414$)$

Before the JCS could ultimately decide on the Soviet DP question, however, another completely unanticipated problem arose. Large numbers of DPs were coming into the zone from Czechoslovakia and Poland. By November, 300 to 400 people a day were entering the U.S. zone, with an additional 150 to 250 a day arriving in western Berlin. Suddenly, the DP problem was growing again, and in the most troubling category of non-repatriables. Added difficulty came because the new wave of DPs were not victims of Nazism, but rather were refugees from the post-war political systems of Eastern Europe. The culmination of all the logistical problems with prisoners, DPs, and transportation raised the zone's population by more than one million people. (Id: 416-17)

\footnotetext{
${ }^{45}$ At the Yalta and Tehran Conferences, Stalin obtained Allied agreement to the repatriation of every so-called "Soviet" citizen held prisoner. The Allied leaders feared the Soviets either might delay or refuse repatriation of the Allied POWs the Red Army had liberated from Nazi POW camps if they refused to do the same.
} 
Housing themselves became a hopeless job for the Germans. The troops and the displaced persons always had first choice. Continuing requisitions for troop and DP billets actually reduced the living space available to the Germans. About half of an estimated seven million refugees who escaped from eastern Germany ahead of the Soviet winter offensive were in SHAEF territory. Undamaged towns and cities had $30-50 \%$ more people than normal. In the heavily bombed larger cities, the populations were increasing at a rate as high as 2,000 people per day during May 1945, but these cities could not accommodate all of their former residents and were beginning to discourage the return of those who did not have needed skills or places to live. A check of the inhabited dwellings in the fall of 1945 showed three quarters needed repairs. More than half had no windows, a third had damaged roofs, and a quarter had unsound walls. People lived in basements, shacks, and ruins that would not be habitable in winter. When cold weather approached in October, military government units initiated a forced exodus from some cities to the country districts. The worst off were the refugees who had no homes to return to and the children evacuated from bombed cities. When travel restrictions were abolished in August 1945, the Germans became a restlessly mobile people. They crisscrossed the country looking for relatives or places to live. For the city dwellers, periodic trips to the country with spare household furnishings and pieces of clothing to trade for food were becoming necessary to survive. According to a U.S. survey in September, the Germans most frequently mentioned food and housing as their main worries. (Id: 279, 351)

As the refugees came in by the thousands, most brought disease with them. In the first months of the occupation, there were waves of dysentery, typhoid, and diphtheria, all spread by sewage leaking into the water system from fractured pipes. Usually, the adults and older children survived, but the first wave of dysentery killed $65 \%$ of the newborn babies in the zone. Military government units quickly took steps to stop the spread of infection, inoculating $75 \%$ of the population against typhoid and typhus within six months. By March 1946, the number of hospital beds increased and 17,000 German doctors 
were at work. British transit camps also began to help solve the DP repatriation problem, processing 2.2 million refugees in less than a year. (Id: 347, 412-13; Barnett: 3) Unfortunately, those individuals who were displaced also faced an elevated risk (even more than others who had lived through the war) of being diagnosed with PTSD, depression, or other somatoform disorders (See Freitag, Braehler, Schmidt S, and Glaesmer, 2013: 310-19). ${ }^{46}$

Germany: Education and Civil Society

Despite these extreme hardships, SHAEF managed to spend significant energy starting Germany's transition to democracy in late-1945/early 1946. A large part of the U.S. effort to promote democratic ideals and eliminate vestiges of the Nazi regime was to change the education system, encourage freedom of the press, and foster free discussion of ideas. In the area of education, particularly, military government gave the Germans significant assistance and direction. The predominant opinion was properly regulated instruction of children would be the best foundation for the future. Schools were also a means of preventing juvenile delinquency, which-as the threat of active German resistance faded-became one of the chief public safety concerns. (Ziemke: 276)

Like everything else in post-surrender Germany, re-opening the schools was not easy. In May of 1945, all schools were closed. Before they could be reopened, SHAEF required suitable buildings be prepared, the certification of non-Nazi teachers, and the printing of new textbooks. Texts perpetuating Nazi ideas were removed, as were the majority of elementary- and secondary-level teachers. (Dobbins, et al: 16-17) Just to reopen the first four grades in one area would require printing six-and-a-quarter million new books. Printing actually began in April 1945, and by May the Army found a superintendent

\footnotetext{
${ }^{46} \mathrm{It}$ is difficult to find information on mental health treatments in 1945. Most research on the psychological impacts of the war and its effect on those with mental disorders/disabilities (other than their treatment by the Nazis) was not conducted until decades later.
} 
of schools who was not a member of the Nazi party because he was half-Jewish. Most teachers were women, now in their forties and fifties, who had been housewives during the Nazi period. (Id: 276-77)

On June 4, 1945-less than one month after Germany's formal surrender-the first school reopened, serving 1,000 students in grades 1 through 4. Grades 5 through 8 opened on October 1, with slightly more students than in 1939 , but with only half the teachers and buildings. The teachers were often persons who had been away from the profession a long time, or who were the products of crash courses in pedagogy. The pupil-teacher ratio was 89 to 1 . Secondary schools were the most difficult to staff and did not begin opening until November and December. The replacements for many Nazi textbooks were relics from the Weimar Republic. The flyleaves included the disclaimer, "The fact of reprinting does not imply, from the educational and other points of view, that this book is absolutely without objection." (Id: 277, 358-60)

Newspapers in post-war Germany were strictly licensed and monitored, and special efforts were made to ensure the press and radio were staffed with personnel with anti-Nazi backgrounds. (Dobbins, et al: 16-17) At the time of surrender, newspapers and radios were shut down and theaters, moving pictures, and concert halls were closed. The information Germans received came from Army newspapers and Radio Luxembourg. At the end of May 1945, Allied-run newspapers had a combined circulation of only five million. All were weeklies and-except for their names and some local newswere standardized in their layout and content. Distribution was no problem, though-the news-hungry Germans were an insatiable market. However, subsequent assessments agreed the Soviet's Radio Berlin was increasing the discontent in the western zones because the Soviets were apparently willing to distinguish between Nazis and non-Nazis, leading the Germans to complain about the dour and grim quality of the output from the U.S.'s Radio Luxembourg and the SHAEF press. (Id: 281-82)

Undoubtedly influenced by the more popular Soviet-operated Radio Berlin, the Army relaxed its policies slightly by the end of May 1945. In the press and radio, German anti-Nazi writers were given 
limited opportunities to express themselves on political subjects. Cultural activities, particularly music, were encouraged. In late June, the first German-run paper received a license, and limited licensing of others was authorized. These papers were subject to pre-publication censorship, though, and their tone and content would be the same as those of the official papers. On August 9, however, post-publication scrutiny replaced pre-publication censorship when the Army authorized licensing of German information services to engage in reporting, editorial writing, and discussion on a "wide variety of subjects", provided military security was not jeopardized. The problem-again-was finding acceptable Germans, as well as enough plants and presses, to resurrect the country's newspaper industry. Almost all of the licensees had been away from publishing for a decade or more. To perpetuate a German democratic press, Americans began recruiting young men in the summer of 1945 to train as the next generation of journalists. The first three hires came directly from prisoner of war cages. By the end of the year, 130 were trained and working as reporters. Thus, there was adequate linkage between the occupation authorities and the population beginning as early as July 1945. (Id: 372 )

Electricity, paper, ink, machine parts, and everything else was in short supply. By the end of the year, though, 23 papers were publishing in the zone, with a combined circulation of more than three million. The issue then became one of paper shortage, so all papers were restricted to twice-weekly publication, with the exception of one daily. Censorship was not a concern; because of the value of the licenses, editors were extremely careful to respect the limits set by the occupation. In fact, the Army permitted use of confiscation and requisitioning to help these business acquire capital. These powers were not used in any other instances to benefit the Germans. (Id: 368-71)

Nazism had also crippled the literary profession. The first new book licenses were issued in July 1945, and eight books came off the presses in October. The Office of War Information also provided 35,000 copies each of 25 U.S. titles. Movie houses gradually began reopening at the end of July, showing one-hour newsreels. As winter approached and occupation forces realized a need to distract the 
Germans from their hardships and to keep young people off the streets, films were once again permitted to be shown. By the end of the year, 350 theaters were open, with more going into business every day. (Id: 373-76)

In April 1946, the Munich police picked up more than 900 vagrants under 21 years of age, nearly a quarter of them girls. The Red Cross had 11,000 vagrants on its rolls. The young people who had homes and families were not much better off because they lived in bombed out cities and went to overcrowded, barely functioning schools. Boys roved the streets and girls in their early teens looked for soldier boyfriends or experimented with prostitution. Concern for German youths was revived due to evidence underground clubs were growing and the zone harbored what was becoming a permanent subculture of vagrant young people. All military government headquarters at the division level or higher were ordered to assign mature officers to look into the youth problem. These officers organized youth committees and sent youth activity liaisons to the units. By mid-June 1946-less than two months after the initial order $-2,500$ youth groups were formed with a total membership of more than 300,000 . Military units supplied athletic equipment and either released or shared requisitioned gymnasiums, swimming pools, and sports fields. They also provided instructors to teach American games. (Id: 438-39)

Thus, U.S. occupation forces in Germany adapted many times to the various challenges and obstacles they faced, moving from victor to concerned authority, to distributor of aid, to reconstruction partner, to-finally-a paternalistic overseer.

\section{Japan: Nutrition and Health}

Japan also dealt with significant destruction and shortages of shelter and essential goods following its surrender. The Allied bombings left nearly nine million people, or $30 \%$ of the urban population, homeless. In Tokyo, $65 \%$ of the homes were destroyed. The national food distribution system totally collapsed, and many faced hunger and starvation. Nearly three million civilians were 
stranded overseas. (Dobbins, et al: 26) Approximately 123,500 children were orphaned or abandoned (Dower, 1999: 63). Equally abandoned were the other Asian residents of Japan, including 1.3 million Koreans, many of whom were brought over as conscripts to work in coal mines and other industries. Nearly 30,000 Allied prisoners of war held in Japanese camps needed food, medical attention, and evacuation. (Dobbins, et al: 27)

The first priority of the occupation troops was to aid Allied prisoners of war and foreign internees being held in Japan. The next order of business was dealing with the nearly seven million Japanese troops, officials, colonists, and merchants stranded overseas at war's end. Although few U.S. policymakers favored highly vindictive policies toward the Japanese, they initially did not plan to devote much money or attention to alleviating the suffering most believed Japan brought upon itself. The task of repatriation was left largely to the Japanese government, which was also responsible for funding it. Under U.S. supervision, the Japanese assembled almost 400 ships, including 200 borrowed from the U.S. military, to return its displaced citizens. Many returnees found their former homes destroyed and their families shattered. (Schaller, 1985: 27; Dower: 54-58) Koreans, Chinese, and other foreign nationals living in Japan found themselves adrift. The Japanese government did not consider them citizens, and thus made no provision for their support. U.S. troops were called upon to oversee the repatriation centers and ensure these individuals were fed, controlled, and given medical attention as they awaited transport home. Life in the over-crowded repatriation centers was grim: there was little food or medical attention, but for many there was no other choice. (Dobbins, et al: 36-37)

With imports of essential commodities and raw materials to Japan completely cut off, food, fuel, clothing, housing, and nearly all the necessities of daily life were in extremely short supply. What remained of Japan's equipment and factories was earmarked for reparations. Military stockpiles were hidden or looted. 1945 witnessed the most disastrous rice harvest since 1910-about 40\% below the normal yield. Although the Japanese assertion ten million might perish without assistance proved to be 
somewhat exaggerated, the situation was still dire. (Dower: 89-97) Washington planners were aware of their duty to provide for the civilians in their area of control, but food supplies were severely limited worldwide, and feeding the Japanese was a low priority. The military orders governing the occupation, JCS Directive 1380/15, instructed SCAP to limit Japanese food relief to what was needed to prevent a level of disease and unrest that could endanger the occupation force and interfere with military operations. Imports of fuel and medicine would also be kept at subsistence levels. (Dobbins, et al: 28, 37)

\section{Japan: Bureaucratic Structures}

In addition to the obvious material damage, the Japanese people were in need of direction, having lost their system of values and the ideological cement solidifying their social structures. It was easy for the Japanese to grant legitimacy to the United States and accept their status as a vanquished nation if it meant a fresh beginning and a chance to start over. (Dower and Maier: 2005) The Japanese state and its people needed to be reinvented, and the American occupation authorities had a free hand to do so. Further, in order to keep their dominant position in society, the Japanese elite had to accept fundamental changes to the political landscape of the country, while the Americans needed them to remain in their positions of power to promote stability and continuity in the eyes of the people. Such exchange of consent constituted the bedrock of further progress in the reconstruction of the Japanese state. (Bridoux: 129, 135-36)

Despite the economic and humanitarian crisis resulting from the war, the emperor still enjoyed support from the vast majority of Japanese. The bureaucracy, the parliament, and the cabinet were intact, functioning, and prepared to cooperate. The key issues for U.S. decision-makers were how to make use of the Japanese government and how extensive an oversight function would be necessary. 
The reform of the Japanese state started with the removal of oppressive laws and agencies holding the minds of the Japanese people in subjection and with the liberation of those jailed for violating these laws. The institutions expressive of totalitarianism were eliminated and a selective purge of the most nationalistic and militaristic elements of the Japanese political elite permitted the rise of moderately conservative Japanese officials and bureaucrats. The decision was made to govern the country through existing organs of government, largely because occupation forces lacked the linguistic and technocratic capacity to govern directly. This left the civilian bureaucracy practically untouched (Bridoux: 134-35). When coupled with the decision to maintain the imperial institution and work through the Japanese government to implement reconstruction policies, this decision led to the maintenance of essential state structures needed to keep the country running and stable. (GHQ/SCAP, 1949: 6)

Important reforms were introduced at the national level, most notably the abolition of the War and Navy Ministries and the break up and dissolution of the once-powerful Home Ministry, which controlled the police and dictated policies at the prefecture level. But for all practical purposes, the bureaucracy remained intact, top to bottom. To a far greater extent than anyone had anticipated, bureaucrats and civil servants cooperated in implementing the early reformist agendas. Democratization of the structure and content of the educational system, for example, required-and receivedenormous input from bureaucrats and teachers at every level. (Dower: 5) Religion was turned into a tool to facilitate consent to American policies. All legal restrictions on freedom of thought, religion, assembly, or speech, and all thought-control laws were abolished. Separation of the state and religion was enforced. The "State Shinto" doctrine was eliminated from school textbooks and its symbols removed from public buildings. The reorganization and liberalization of labor, and the assimilation of democratic principles by employers, workers, and their unions was another target for the democratization of civil society. (Bridoux: 141) 
MacArthur worried his democratization program would be undermined by hunger and lobbied for substantial assistance, arguing the United States would either have to provide more food or more forces. He was initially able to supplement supplies with 800,000 tons of surplus military food resulting from the rapid drawdown of occupation forces. His budget request included $\$ 250$ million $^{47}$ for food, fertilizer, petroleum products, and medicine, and he received the entire amount. (Cohen, 1987: 144) This food aid prevented acute malnutrition throughout the nation. For many Japanese, particularly young children whose school lunches consisted mostly of donated food, this assistance symbolized U.S. generosity and wealth. In addition to food released from military forces, aid came primarily from GARIOA and gifts sent through aid organizations from Japanese residents in the United States. ${ }^{48}$ Together with the chocolate and chewing gum U.S. soldiers gave away, as well as other goods for the troops that found their way onto the black market, the food aid imprinted an image of U.S. affluence on the Japanese psyche they admired, and to which they aspired. (Dobbins, et al: 37-38)

\section{Japan: Education and Civil Society}

As in Germany, an essential component of democratization and demilitarization was educational reform. Early efforts focused on removal of all traces of emperor worship and militarism from the classrooms and curriculums. Lacking funds and time to replace the textbooks, teachers or students were directed to rip out or line through offending language. Saluting the flag, singing the national anthem, and bowing to the emperor's portrait were prohibited. Local military government teams were dispatched to the schools in their districts to ascertain whether these SCAP directives were being carried out. Decentralization of education was viewed as vital to the permanent removal of the ability to

\footnotetext{
${ }^{47}$ This amount exceeded the combined budgets of the U.S. Departments of Commerce, Justice, and Labor for the same time period.

${ }^{48}$ Occupation authorities in Germany had actually declined some of the GARIOA food shipments, describing them as hardly better than cattle feed; Japan, however, was too hungry to care.
} 
indoctrinate Japanese students in the narrow form of nationalism believed to have sustained support for the war. (Id: 44-45) This reform required removal of strict control by the central government, making them responsible only for the legislation of minimum standards. Textbook writing and production were removed from the Ministry of Education and opened to free competitive markets on the basis of national standards. ${ }^{49}$

In addition to reform of the education system, a key task was reforming the political system. (Dobbins, et al: 43) Prior to the war, political parties vied for power with the military, the bureaucracy, the leading industrialists, and groups close to the emperor. The military was not subordinate to civilian control, a structural flaw it exploited to the fullest. (Van Buren: 28) Post-surrender, it was necessary to erase negative perceptions of Japanese imperialism and militarism produced by the wartime propaganda. SCAP's Civil Information and Education Section (CIES) set out to reorient Japanese civil society. CIES maintained close relations with Japanese professionals of information and culture, and emphasized their role and responsibility in a democratic society. In addition, 17 information centers with libraries (and U.S. librarians) opened in major cities, organizing children's story hours, English language classes, lectures, and American music concerts. (GHO/SCAP, 1950: 5-6) Taking their direction from the Potsdam Conference and other formal guidance documents, General MacArthur and his staff assumed the task of demilitarization and democratization of Japan with what is often described as messianic zeal.

\section{Iraq: Popular Ideology}

In the wake of the Baath regime's fall, the Iraqi institutional structure collapsed. The official state all but disappeared, while the "shadow state" survived and disintegrated into myriad components,

\footnotetext{
${ }^{49}$ The re-writing of textbooks reached its peak with an attempt at replacing the Japanese writing system-deemed an obstacle to learning - with a phonetic system and use of Roman characters. This constituted an enormous display of arrogance, egocentricity, and racism, basically inviting the Japanese people to commit "cultural suicide". The effort ultimately failed. (Toshio, 1982: 206)
} 
falling back on local ties and communities and positioning itself to reform according to new dispensations of power. The Baath party, as an institution, was hollowed out by Saddam and had no real political authority by 2003 , but served as an instrument of social monitoring and control. Like the Chinese Communist Party under Mao, its presence was felt on every block. The collapse of civil society left a void the bad guys rushed to fill. (Tripp, 2007: 276)

Informal power structures are common throughout the Arab world. Wasta, or clout based on personal, family, or clan connections, both subverts formal bureaucracies and helps to soften the edges of the region's police states. Thus, even after the removal of Saddam and his key lieutenants, thousands or tens of thousands of Iraqis exercised influence and deployed resources, regardless of their formal bureaucratic positions. Understanding the engineering of these power structures was a challenge for the transitional authorities. (Dobbins, et al: 189)

In 2003, Iraq was an urban society, with two-thirds of Iraqis living in cities. Baghdad had over five million people, and twelve other cities had populations of about one million or more. Before and during the conflict, U.S. and UK forces took major steps to lessen the post-war humanitarian burden, including minimalizing damage to key nodes in the civil infrastructure (bridges, electricity distribution network, etc.), stockpiling supplies in the region, and securing key entry routes (the Umm Qasr port and the land route from Jordan). (Dobbins, et al: 183) But the Iraqi population was much less resilient in 2003 than it was in 1991 at the end of the first Gulf War. Declines in employment, nutrition, income, health, and household assets meant Iraqis were much less able to fend for themselves than they were a decade earlier. They were more likely to be suffering from disease and hunger, and the majority of the population had become dependent on the state for the bulk of their food, in addition to other supplies and services. The World Food Program estimated 16 million Iraqis-approximately $60 \%$ of the total 
population-relied solely on food rations distributed through the UN's Oil-For-Food Program ${ }^{50}$ to meet household needs. (USAID, 2003: No. 24) During the war, however, this supply network was dislocated because of the disruption in the civil administration. Though the power generation and distribution and the water supply and sanitation infrastructure were rebuilt after being damaged in the 1991 conflict, all suffered from inadequate maintenance and lack of spare parts over the next 12 years. (Dobbins, et al: 181-82)

Declining aspirations were also seen in the nation's ideology, mainly from the Arab population in the center. By 2003, the early Baath drive to remake Iraq and the Arab world had disappeared; instead, public rhetoric and actions tilted heavily towards Islam. The struggle against the United States and the United Kingdom became known as jihad, and the population was encouraged to turn to religion. The emphasis on Islam, begun during the Iran-Iraq war as a way of placating the Shia, grew in the 1990s into regime policy as the sanctions imposed on Iraq required ever-greater sacrifice. Religion served as a possible escape mechanism for a weary population. By 2003, Islam was firmly embedded in the nation's ideology and symbolism and religious zealously was imbedded in Baathist rhetoric. But the main thrust of Saddam's message was the need to defend the country against foreign enemies. A typical fifth-grade textbook exhorted students to be loyal to the state, the "revolution, the party, and the struggle". The main vehicle for expressing national identity was the military, and students were urged to join paramilitary formations. Overall, patriotism was defined through the values of sacrifice, honor, and courage. (Marr: 244)

\footnotetext{
${ }^{50}$ The Oil-for-Food Program was established by the United Nations in 1995 (under UN Security Council Resolution 986) to allow Iraq to sell oil on the world market in exchange for food, medicine, and other humanitarian needs for ordinary Iraqi citizens without allowing Iraq to boost its military capabilities.
} 
Iraq: Living Standards

Civil servants suffered heavily after 1991 in terms of declining income and living standards. Anecdotal evidence suggests they had difficulty surviving on their salaries and were forced to draw on their assets or take on additional work. (Dobbins, et al: 188) During the 1990s, Saddam's regime gave more authority to traditional tribal leaders and power structures at the expense of the civil government. Meanwhile, in the autonomous North, a separate Kurdish identity took root. Its school curriculum instilled loyalty to a new identity: Kurdistan. By 2003, classes in most schools were taught in Kurdish, increasingly raising the question of how well the new generation of Kurds would be able to communicate with Iraqi Arabs in a future, more unified state. (Marr: 248)

The vibrant middle class that emerged in the middle of the $20^{\text {th }}$ century and provided the basis for Iraq's civil society was hollowed out by a decade of sanctions and turmoil. Organized crime and banditry became deeply rooted in society. (Dobbins, et al: xxvi, 169) By the $21^{\text {st }}$ century, income and status disparities within Iraq's social structure were much higher than they had been in the 1970s. A new upper and affluent class emerged, including top-level members of the bureaucracy and the party, as well as entrepreneurs, who often skimmed profits from the system. Meanwhile, those living mostly on salaries could not keep up and unskilled workers simply sank deeper into poverty. Instead of upward social mobility, Iraq saw downward movement and the shrinkage of the middle class. (Marr: 240)

During Saddam's reign, his regime faced continuing opposition from Iraqis outside the country. Prior to the Gulf War, estimates indicate the number of exiles may have reached 1.5 million, with the war, the rebellion, and the on-going sanctions pushing this number as high as two to three million. The largest group was in Shia-dominated Iran, numbering between one-half to one million; others were in neighboring Arab countries, particularly Jordan, Syria, and the Arab Gulf states. In Europe, the major concentration was in England, which housed hundreds of thousands of Iraqi exiles. Some were scattered 
across the U.S., and though a few were poor, many were from Iraq's educated and skilled middle class. (Id: 250)

Iraq: Political Activity

The main components of the opposition to Saddam became clear by the first Gulf War: there were two Kurdish parties, KDP and PKU; two Shia Islamist groups, SCIRI and Da'wa; and the Iraq Communist Party. In 1992, a number of these groups met in Vienna and formed an umbrella group, the Iraq National Congress (INC), which incorporated some, but not all, of the existing parties. For a time, the INC made progress establishing its presence on Iraqi soil and acquired a headquarters in the region. It operated a radio station, reaching into Iraq, and printed leaflets and newspapers, acting as a magnet to attract defectors, especially from the military. These individuals were housed, fed, and trained as the beginnings of a militia to be added to the Kurdish pesh merga. It soon became apparent the United States-specifically, the CIA-was funding these activities, largely due to the efforts and persuasion of Ahmed Chalabi, an Iraqi exile since 1965. (Id: 252)

Initially, the $\mathrm{CIA}$ and others in the Clinton administration were only willing to give limited support to Chalabi and the exiles, choosing instead to focus on a possible coup by disaffected officers in the center of Saddam's regime. But the rise of neoconservative political forces in America gave Chalabi an opening. He took the lead in trying to organize the disparate opposition groups, independent of any Middle Eastern sponsors. His organizational abilities, tenacity, and effectiveness in dealing with Western politicians soon made him the leading spokesman for the exiled opposition. But despite his intellectual talents, Chalabi had some obvious setbacks making him extremely controversial. He had not lived in Iraq for decades, he was under a cloud of suspicion for allegations of banking fraud in Jordan, and he was seen to be heavy-handed when dealing with his colleagues. Also-in contrast to Shia Islamist forces and the Kurds - the exiled opposition leaders on whom the United States appeared to be counting to take 
charge in post-Baathist Iraq had no military force or people on the ground, particularly in the center, where the heart of the regime was located. They would essentially have to rely on foreign support-say, from the United States - to gain any power in a nation that deeply questioned outside intervention. (Id: $252-53,265)$ The weaknesses of the exile opposition soon became clear. Deep ideological divisions within its ranks prevented effective collaborations and only a few of them exhibited any enthusiasm for engaging their supposed constituents. (Diamond: 114)

Iraq had relatively well-established formal administrative structures covering all aspects of society, from central to local government, from education through public works, and throughout the oil industry. These structures were staffed by well-educated and competent technocrats. Though many of the most-educated and skilled elite Iraqi technocrats were in exile in 2003 , some returned to assist in the reconstruction, lending their expertise and knowledge to the effort. (Dobbins, et al: 187) Getting the civil administration back on its feet in the absence of the old regime's power structures was obviously difficult, but should not have taken very long, even with the breakdown of law and order. Building a stable and lasting civil administration required a substantial overhaul of personnel systems, including purging senior Baathists and carefully integrating expatriates. The U.S. needed to neutralize the informal networks of power subverting formal bureaucratic structures (Id: 171, 202), but each of these tasks was accomplished in less than a year in both Germany and Japan.

In recent history, Iraq's local governance had been dominated by the center; the idea of the individual's role within civil society was grossly under-developed. Now, the CPA's Local Government Program was seeking to reverse that. More than a thousand Iraqis-many of them teachers, doctors, and engineers - began working in 17 of the 18 provinces and in four regional hubs. Local councils had no formal authority, no money, and questionable legitimacy, since many had been appointed by U.S. military forces in the area or "elected" through unofficial processes. The challenges for decentralization were clear, but in late autumn 2003, the CPA put plans for a new policy on hold, even though it would 
have allowed provincial ministry offices to reallocate funds received from the central government. The CPA still wanted local councils to begin exercising responsibility so Iraqis could start establishing ownership of the reconstruction process, but this brought into question the leadership of those projects. Advisors urged the CPA to give the councils real authority over resources and staff, but money and authority did not flow downwards, sending a confusing mixed message. Often, city council members and police officers were not paid for months. (Diamond: 114-15)

Iraq: Relief Aid

The U.S. military was proactive in delivering aid through its limited civil affairs units, but relationships with relief agencies were unsettled. U.S. and UK military personnel were primarily responsible for the distribution of aid, leading to confusion over the role of USAID, the United States Agency for International Development. Military logistics systems were not designed, nor were military personnel trained, for this role. Indeed, the UN and other NGOs argued the direct delivery of assistance by the U.S. military was causing more cons than pros (UN: 2002). Occupation officials were cautioned not to allow humanitarian aid to translate into dependency (Dobbins, et al: 184, 201).

$\$ 6.2$ billion $-22 \%$ of the total aid-was allocated to assist with democratization (including building a civil society), educational reform, healthcare, and the expansion of the private sector (USAID, 2004: 14-15; SIGIR, 2004: 52). This money might have been better spent to fund quick projects, such as clearing war rubble, making damaged buildings safe, and repairing combat damage, which would also provide jobs and promote general feelings among Iraqis of progress being made. Instead, the CPA fell into the classic blunder of most foreign assistance programs: trying to do too much with too little. Many of the occupation's programs were too grand and did not improve the average Iraqi's life.

Only a small amount of emergency food and relief aid was ultimately needed. An audit of existing infrastructure facilities was implemented and necessary modernization work began early in the 
occupation (USAID, 2004: 14-15; SIGIR, 2004: 52); however, security concerns once again caused reconstruction projects to slow down, leaving Iraqis in some regions without decent access to basic services (SIGIR, 2007: 127; 2008a: 138). Given the security situation, access to medical care was often a case of life or death. Consequently, the CPA freed the financial resources needed for a quick improvement of the healthcare system in Iraq. But the medical supply distribution system was plagued by corruption and inefficiencies, leading to shortages of medication (DoD, 2008: 15). Without regularly scheduled follow-up care, the value of any direct aid was quickly diminished (Van Buren: 127).

In some poor areas, especially the south, Iranian charities were a primary source of propane, food, and other services people expected the government to provide, as Saddam more or less had done. Militiamen commandeered shuttered power plants and private generators for the public's use, turning the militants into local heroes. Though the U.S. military was never able to prove such rumors, the peoples' belief in their validity made one thing clear-the "criminals" were able to provide services the mighty U.S. government could not. (Van Buren: 56)

Iraq: Institutional Challenges

In Sunni areas, local groups were generally hostile to the occupation. They also had Baathist supporters, which gave the movement a nationalist character that soon crystallized into an insurgency. Other extremist groups penetrated from outside Iraq, but the most significant-and ultimately, disruptive-came from inside: that of Muqtada al Sadr, the son of an assassinated and extremely influential Shia cleric. Sadr and other young clerics $^{51}$ rapidly seized control in poorer areas, using their supporters as foot soldiers, occupying mosques, hospitals, schools, and social welfare centers. The rapid

\footnotetext{
${ }^{51}$ Most Shia denied Sadr was a true cleric; rather, he and his followers began using the title without obtaining the proper training and experience.
} 
and sudden emergence of this insider group in the summer of 2003 soon generated an internal Shia struggle for power in the south. (Marr: 264)

One of the most important sectors of the population to be affected by Saddam's regime was Iraq's youth: they lost the benefit of education and many possibilities for the future. Credible figures show the literacy rate fell $10 \%$ during the sanctions period and stood at $67 \%$ in 2003 , whereas the rest of the Arab world's had risen. The 1997 census showed over half the population was below the age of 19. An absolute majority of the population were born and raised during the Baath regime; it was the only system they knew. There was significant evidence showing youths turned to religion, allowing more fundamentalist views to take root. (Marr: 240-41) During the occupation, children were seen everywhere ${ }^{52}$, but few attended schools in rural areas and those who did only went half-days because it was no longer safe for boys and girls to attend class together, as they had under the more secular Baathist-regime. ${ }^{53}$ The new government could not afford to immediately double the number of schools (Van Buren: 83) and even if they could, there was not enough security to ensure safe passage for the students to get to them. ${ }^{54}$

The CPA's plan to promote democratization was to have the regional and provincial offices, Iraqi NGOs, and coalition forces distribute up to one million leaflets (printed in both Arabic and Kurdish) and 40,000 posters each week as part of a bold, mutually reinforcing, multimedia campaign. Another major

\footnotetext{
${ }^{52}$ Two school-age girls were seen by the author every day when she traveled to the central courthouse in Baghdad in 2008. Their mother worked in the cafeteria and brought them to work with her because it was too dangerous to leave them alone at home and the neighborhood school had been destroyed. Both girls suffered from ringworm. When medication was provided to them, it was sold for food. Therefore, an army medic began administering it to the girls each day rather than giving a tube of ointment to take home.

${ }^{53}$ In spring 2008, several female Iraqis discussed with the author how they had not worn the traditional Muslim dress - hijab and abaya-prior to the occupation. After the U.S. began running the country, however, they started doing so because they were threatened by more fundamental segments of society for looking "too Western". One of these women was not even Muslim - she was a practicing Catholic.

${ }^{54}$ The author personally knew a court investigator's son who could not attend school for several weeks because the building was damaged in an explosion. Eventually, the investigator himself-who worked closely with the author each day-stopped coming to work because the neighborhood became too dangerous for him to leave the house.
} 
part of the project would unfold on radio and television. Each week there would be a nationally broadcast public service announcement to distill and dramatize the content of that week's civic education leaflet. There would also be a third, crucial component: face-to-face democracy dialogues and town hall meetings. To accomplish this, CPA governance offices would need to recruit and train another 500-600 Iraqis (university students, NGOs, teachers, and others) to facilitate the dialogues. There was also a demand for educators-ideally, Iraqis, but international staff, if necessary-who could give lectures around the country on the elements of democracy and citizenship. (Diamond: 109-113) CPA officials worked for months to help organize, train, and support a new generation of Iraqi NGOs. Sometimes the effort involved helping local professionals - for example, bar associations and medical groups-reorganize under leadership that was not an extension of the Baath Party, and at other times entailed support for new organizations, including a number of human rights and democracy advocacy groups. In most of the country, the CPA worked to encourage the formation of women's organizations and to establish centers where women could receive instruction in computers and other basic skills. (Diamond: 125)

By the time the CPA transferred power in June 2004, approximately 300,000 Iraqis had participated in democracy dialogues (Id: 287 ), a number the CPA touted but was actually less than $1 \%$ of the population. As always, due to security circumstances, these reforms progressed slowly. All of these communications strategies fell short when most Iraqis still did not have access to the basic services they had prior to the invasion. Failing in the propaganda war meant the CPA failed to win the war of ideas. (Bridoux: 141)

\section{Summary}

As illustrated in detail earlier in this work, the military invasion of Iraq sacrificed substance for speed. In Germany, troops on the ground not only conquered the nation, they secured more than five 
million prisoners of war and disarmed enemy soldiers along the way. Japan had 1.3 million displaced individuals the army had to account for. But no one saw a need to secure Iraqi military installations, manufacturing facilities, or even towns on the march to Baghdad. The effect these different approaches had on each nation's Civil Institutions is clear. Many argued Iraq's defeat was not severe enough, as the citizens were not struggling to survive and had time and energy to devote to other tasks. Ironically, this is a requirement and necessary first step in building a civil society-many Iraqis just went about doing so violently.

German and Japanese occupation officials had sufficient troops on hand-and were willing-to provide direct military assistance, rather than going through laborious contracting processes to award jobs. In Germany, children were ordered to bring wood to school to help with heating, but no similar steps were taken in Iraq: Bremer never declared martial law, or ordered Iraqis to help with the reconstruction of their own country. Doing so-and paying them-would have solved two problems at once: getting the infrastructure repaired and boosting the economy, not to mention giving local citizens a sense of pride and ownership. Instead, the CPA relied on foreign contractors who used third-party nationals as cheap labor, distorting the labor market. Bremer wanted local councils to take control of reconstruction projects, but gave them no money or administrative power to do so. He frequently talked about decentralization, then micro-managed everything from high levels. Police officers and local officials frequently went for months without pay, but saw fat government contracts awarded to international companies.

Though all three nations were totalitarian, German and Japanese citizens were fairly selfsufficient, whereas Iraqis had lived on subsidies for nearly two decades. $60 \%$ were dependent on the Oil for Food Program for survival: they needed to be taught to make a living. Instead, the U.S. spent vast sums of money on handouts and prevented citizens from doing things for themselves. Eventually, Iraqis learned if they waited long enough, the U.S. would fix the most severe problems, at least in the short- 
term. The result were things like dozens of USAID operated clinics, but no efforts to train doctors and nurses, or build operational, long-term healthcare facilities.

U.S. forces after World War II found themselves repeatedly faced with greater burdens and fewer-than-expected resources due to worldwide shortages. Military government liaisons told local German officials they would be held responsible for any actions-positive or negative-occurring in their districts. This mobilized the citizenry to begin policing themselves. These hurdles did not exist in Iraq, but Bremer and the CPA seemed to always be tottering between over-directing in some areas and not going far enough in others. For example, getting children into school is recognized worldwide as a way to prevent juvenile delinquency, but even when there were no security concerns, troops in Iraq did not ensure children attended. To make Iraqis more self-sufficient, trade schools and universities should have been operational in the beginning, even utilizing troops as teachers, if necessary. Instead, the buildings were deemed subpar, and learning institutions remained closed until new ones could be built. This took years, and by then there were no teachers to work in them. By contrast, in 1945, officials made do with what they had. German teachers and administrators were hired within a month and taught up to 89 students in one classroom. Japanese students kept their old textbooks, but were instructed to rip out or line through offensive passages. SHAEF and MacArthur both realized the imperfect solution implemented on time is far superior to the perfect solution implemented late.

Many of the justifications previous scholars have used for ease of which the Japanese adopted regime change also apply to Iraq. After decades of Imperial rule, Japan was in need of a fresh start and reinvention; following 35 years of Baathist rule, the same was true of Iraq. Yet the U.S. approached the re-structuring of these societies in conflicting ways. In the later years of World War II, the emperor of Japan demanded greater and greater sacrifice and loyalty from the people; Saddam Hussein's approach was no different, particularly in the last years of the sanctions regime. The CPA did not capitalize on this "service to the state" mentality as MacArthur did, apparently favoring a "clean slate" position. 
Americans allowed Japanese elites to remain in their positions as a means of promoting stability and gaining consent from the population-most mid-level bureaucrats remained at their post to facilitate governmental operations. In Iraq, the ruling Sunni elite were all removed from the government and any other areas of power and influence. Perhaps this was because, as Sunnis, they were a more easilyidentified group, similar to the Nazis, and thus it was harder to deny their complicity in regime actions.

Lessons learned in 1945-46 show most former Nazis were eventually cleared to return to the workforce, even hold elected office. The same occurred with purged Japanese officials when it became clear the country could not run effectively without them. Nevertheless, Bremer still pursued deBaathification, and its intensity waivered frequently during the following two years, causing most former party members to repeatedly doubt their status and station. Iraq was left with a bumbling group of exile politicians to lead it, who had never before shown any ability or inclination to work across ideological divides or even engage with constituents. Yet the administration seemed to think this would change when the group was given real power.

Showing affluence and generosity in Japan had a positive affect-the Japanese were starving and saw the West as a benevolent land. Using the same approach in Iraq was perceived as a clumsy attempt to buy love, just as Saddam always did, since the efforts were not accompanied by actual improvements in daily living. Previous interactions between the U.S. and the Arab world left a sour taste in the average Iraqi's mouth, so any attempt to curry favor resulted in distrust. The CPA would have been far better served putting its resources towards projects actually benefitting the people, such as a working water station, rather than handing out bottles of soda. When security was an issue, though, one was far easier than the other, and made for good photo ops.

The majority of occupation staffers in Iraq lived sequestered behind massive walls and multiple checkpoints - to the extent they had to rely on $\mathrm{CNN}$ and other news outlets to learn about what was happening just a few blocks away. Officers in Germany lived among the population and learned the 
culture; in Iraq, most soldiers feared interacting with the public on an individual level. In Japan, efforts to force a switch to the Roman alphabet were quickly set aside when it was realized this was viewed as "cultural suicide"; yet, in Baghdad, officials continually tried to convince Iraqis to leave behind their tribal cultures ${ }^{55}$, rather than working within these constructs. Since most Iraqis were in awe of America to a certain extent ${ }^{56}$, had more sensitivity been displayed by troops on the ground, many more citizens could likely have been convinced to support the occupation.

The contest for the Iraq's future caused CPA decisions to collide with reality and the expectations of Iraq's power players (Bridoux: 108). While the CPA saw its mission as trending towards the bigger picture, the military often focused on more immediate things. The argument was not a simple one: was it right to focus on a five-year, water plant rebuilding project while local children suffered from dysentery easily relieved by bringing in truckloads of bottled water every day? In an ideal world, both could be done-and, in Germany and Japan, they were, to some extent; but in Iraq, using coalition cash rather than Iraqi institutions set back efforts to foster self-reliance and did little to re-boot local economies. Many small towns even gave up lobbying the central government for more money, knowing the Americans would eventually pay for everything. Thus, instead of encouraging growth and capacity of civic functions, massive hemorrhaging of cash discouraged them. Then, when U.S. focus shifted to another area or project, there was no one willing or able to take over. (Van Buren: 59-50)

\footnotetext{
${ }^{55}$ The author saw Iraqi court transcripts where U.S. officials had removed all reference to tribal affiliation from the documents. They were under the impression judges would be biased by this information. Of course, the first question the judge asked every defendant was, "What is your tribe?" In a culture where this information is paramount to personal identity, the CPA just did not get it.

${ }^{56}$ Two occasions, particularly, stick out in the author's mind. First, she let an Iraqi court staffer borrow her pen. It was a plain Bic pen-the kind purchased in packs of ten in the U.S. The staffer seemed so enamored with the pen she let him keep it, and he walked off showing everyone his "American pen". The author did not have the heart to tell him it was likely made in Taiwan. Second, the author received a care package containing bubble gum, and gave pieces to court personnel who asked for it. Apparently, there is no "bubble" gum in Iraq, so she spent an entire afternoon teaching grown men how to blow bubbles with gum. One gentleman came to work the next day and excitedly told her how he taught his daughter to chew "American gum".
} 
Iraq was not lacking in civil institutions in 2003; in fact, a far greater percentage of its population was willing to participate in the democratic process than in Germany, making it difficult to say deficiencies in this area hampered reconstruction efforts. Rather, it was the CPA's procedures for harnessing these institutions (if not outright ignoring them altogether) that contributed to failure. This is highlighted further in the next chapter, since the experiences each force had in implementing their own measures are just as -if not more-important than how they approached existing institutions, though the former has been previously overlooked in most comparative works. 


\section{CHAPTER 5 \\ INSTIGATED FACTORS: GERMANY, JAPAN \& IRAQ}

The previous chapters' focus was on contextual and hybrid factors-those long agreed-on points of analysis by scholars for which occupation officials have relatively low levels of control. The purpose of this research is to introduce new Instigated Factors for consideration not routinely examined by scholars when analyzing post-conflict reconstruction. It is the author's assertion these factors are, in fact, more important than the contextual and hybrid factors already discussed when evaluating whether a postconflict occupation and democratic transition will succeed. Upon examination, these factors should be more relevant to the overall occupation effort, since officials have almost complete control over their implementation and operation. By illustrating their importance and encouraging more attention be paid to them, better decisions regarding these factors could result in greater gains the future.

\section{Operational Planning}

The establishment of military government in Germany and Japan was backed by the ubiquitous presence of a mass army, whereas in Iraq, the "light" hi-tech American military proved far too small for the comparable task (Barnett, 2005: vi). Many have argued this failure was not due to the size of the force, but rather to the time given to planning the operation-World War II planners had significantly more time to prepare for a post-conflict occupation. As explained below, this was not the case.

\section{Germany and Japan}

Despite years of planning before the end of World War II, the United States still underestimated the amount of time required for the complex task of rebuilding infrastructure, vetting officials, restructuring institutions, and transforming citizens' relationship with their government (Jennings, 2003: 27). In January 1944, the Chief of Staff of the Supreme Allied Commander (COSSAC) recognized the 
complexity of the occupation and called for studies on armistice terms, sanctions, disarmament, displaced persons, prisoners of war, martial law, disposal of captured war materiel, and coordination of movement and transportation. By April 1944, 72 staff studies were underway on post-conflict subjects. (McCreedy, 2004: 10)

Thanks to the duration of the Pacific War, American officials benefited from an extensive period of planning for post-conflict occupation and reconstruction of Japan. The knowledge of the Japanese political and economic conditions also contributed to the efficient design of postwar policies in that country. (Bridoux, 2011: 164) Japan had been engaged in aggression in Asia since 1931, open war against China began in 1937, and the strike against Pearl Harbor took place in 1941 (Dower, 2003: 2). The speed of the Japanese surrender caught the Americans somewhat by surprise, however, so MacArthur requested the troops planned for the two-phase invasion of Japan-an invasion that was no longer necessary-be made available to him for occupation duties. He initially estimated he would need between 200,000 to 600,000 troops in the first six months of the occupation to pacify and control the Japanese. (Dobbins, et al, 2003: 32-33) Originally, the invasion called for 600,000 troops, anticipating this number would include 315,000 Americans; 135,000 British troops; 60,000 Nationalist Chinese; and 175,000 Soviets (Cohen, 1987: 60). When the invasion did not occur, only the British Commonwealth shared the occupation responsibilities with the United States (Dobbins, et al: 30). Nonetheless, in 1945 there were still more than 354,000 U.S. troops in Japan to assist with occupation efforts (U.S. War Department, 1945).

Germany's aggression was even more open and audacious than Japan's. The area in Germany remaining under U.S. control was about the size of Kentucky, but with five times the population (Ziemke, 1975: 396). On V-E Day, General Eisenhower had 61 divisions (1.6 million soldiers) in Germany and a total of 3 million troops in Europe. These soldiers became the occupation force for the U.S. sector. They manned border crossings, maintained checkpoints at road junctions, and conducted patrols throughout 
the sector. The occupation was comprehensive and demonstrated the scope of the German defeat. After V-J Day and Japan's surrender, however, U.S. demobilization happened quickly, reducing the level of forces in Europe. (Dobbins, et al: 9) Records show $40 \%$ of the officers and $50 \%$ of the enlisted men in military government positions were eligible for discharge by the end of 1945 (Ziemke: 364-65).

U.S. officials in Germany developed an Occupational Troop Basis goal of 404,500, but later reduced this number to 370,000 and then went down to 200,000 -or only five divisions - when domestic pressures became acute to bring the soldiers home (Dobbins, et al: 9; Ziemke: 423). Army groups then complained their responsibilities exceeded their resources, particularly in matters reaching beyond their boundaries, such as production control, operation of railroads, and maintenance of the electrical power system. Between August and October 1945, consolidation of training and additions of new personnel raised military government strengths at all levels. Thus, even under the shadow of massive redeployments, 200,000 troops was the low point of available manpower in Germany. (Ziemke: $273,396,423)$

Though the work was immense, both Germany and Japan had the requisite number of U.S. personnel for their reconstruction. More importantly, there were sufficient military troops to maintain order.

Iraq: Operation DESERT CROSSING

Despite many beliefs to the contrary, U.S. Central Command (CENTCOM) had planned the invasion of Iraq and removal of Saddam Hussein for several years. OPLAN (Operations Plan) 1003 was written as a contingency plan for such an occurrence in the early 1990s, but had not been updated since 1998 and was based on Desert Storm era thinking. It also did not take into account current troop dispersions, advances in technology, or the lessons learned in Afghanistan. (Keifer, 2009: 19-20) 
In December 1998, after Saddam failed to comply with UN Security Council Resolutions or allow UN inspectors ${ }^{57}$, the United States launched Operation: DESERT FOX, a four-day bombing campaign. General Anthony Zinni, Commander of U.S. forces in Southwest Asia from 1997-2000, was told by many of America's Arab allies this operation, "almost caused an implosion." Arab leaders were concerned about the possibility of the bombs causing massive waves of refugees flooding into their country and major economic dislocations. Zinni realized such an eventuality would cause chaos throughout the region, which would require clean-up and reconstruction. Should Saddam fall, it could create a bigger problem than the one the Middle East already had. He also realized there was no plan in place to deal with such an occurrence. In June 1999, Zinni held a classified war game on what such an aftermath might look like. Representatives from the State Department and the U.S. Agency for International Development (USAID) also participated. According to Zinni, the results "shocked the hell" out of him. In the wake of the war game, he ordered CENTCOM to begin planning for the fall of Saddam's regime, but he could not get other parts of the government to become involved. Eventually, these plans became known as Desert Crossing, and detailed the steps required following the fall of Saddam.

One year prior to DESERT FOX, a new think tank had been formed: the Project for a New American Century. The group eventually became a base of support for Ahmed Chalabi ${ }^{58}$ and ultimately persuaded many neoconservative politicians who would later be influential in the Bush administration to move towards regime change in Iraq..$^{59}$ In October 1998, largely through the efforts of the Project, Congress appropriated $\$ 97$ million to the opposition of Saddam. These funds were to include military

\footnotetext{
${ }^{57}$ One of the conditions following the 1991 Gulf War was Iraq would allow UN inspectors to examine and investigate its capabilities for building nuclear weapons. Iraq spent the next eight years frustrating, hampering, and deceiving the inspectors, until the UN withdrew them in 1998, days before Desert Fox began.

${ }^{58}$ As noted several times in this work, Chalabi had almost no support within Iraq, and his influence among the population was nonexistent. Regardless, occupation officials seemed to rely on his opinion for some time, over the advice of more established and powerful local Iraqi leaders. His alleged assistance as an informant for the CIA apparently made him a favorite of the Bush administration.

59 These politicians included Dick Cheney, Donald Rumsfeld, Paul Wolfowitz, and Zalmay Khalilzad, a former diplomat and a counselor at the Center for Strategic and International Studies.
} 
training for opposition groups inside Iraq, such as the KDP, the PUK, and SCIRI-all of which later formed militias during the occupation. (Marr, 2012: 253-54) But an unexpected result of DESERT FOX was a decline in cooperation with U.S. intelligence agencies from inside Iraq. After the operation, there was a significant difference in the quality and verifiability of information. This data vacuum led to catastrophic misassumptions during the invasion planning four years later. (Ricks, 2006/07: 20, 22, 86)

Iraq: Earlier Concerns

Many generals had three major concerns about invading Iraq: the possibility of Saddam using weapons of mass destruction, the danger of becoming enmeshed in urban warfare, and the worry a postwar occupation could be costly, especially if the United States had to put in thousands of troops to hold the country together (Id: 40). The planners of the Iraq invasion believed either one of two situations regarding the governance of Iraq may occur: either large numbers of coalition forces and martial law would be required for years, or the Iraqis might claim their country as their own, welcoming liberation and organizing themselves swiftly without coalition help. It was thought a consensus leadersimilar to Hamid Karzai in Afghanistan-could make the establishment of an Iraqi civilian government a short-term prospect. Ahmed Chalabi was considered by many U.S. officials to be a logical choice for this role, given his position as head of the exiled Iraqi National Congress, even though he had not lived in Iraq for more than 30 years. (Keifer: 22-23)

From the outset, there were disagreements between Secretary of Defense Donald Rumsfeld and the military about whether to invade Iraq and how many troops would be necessary. These disagreements were rooted in conflicting assessments regarding the threat Iraq presented and the difficulties likely to result from invading and occupying the country. (Ricks: 42-34) As late as February 2003, Deputy Secretary of Defense Paul Wolfowitz believed once Saddam fell, the Iraqis would cheer the American troops. He was dismissive of the notion a U.S. intervention might unleash fighting between 
the Sunnis, Shiites, and Kurds. (DoD News, Feb 24, 2003) He was also extraordinarily optimistic about Iraq's oil exports, claiming they would likely pay for much of the country's post-war reconstruction (Wolfowitz Congressional Testimony, Feb 2003).

The Army Chief of Staff, General Shinseki, was less optimistic. A series of war games over the previous year had strengthened his sense the U.S. military would need a larger force than Rumsfeld was contemplating -in fact, the postwar force would need to be bigger than the wartime force. Using the same formula the U.S. military had used in Bosnia-one soldier for every 15,000 citizens-Shinseki believed at least 300,000 troops would be needed in post-combat Iraq. (Ricks: 96) In fact, previous reconstruction efforts had shown in order to effectively face increasing levels of violence, improve the security situation, and establish law and order after a conflict, a ratio of 1,000 soldiers for every 100,000 inhabitants was the norm; in other words, a ratio of 1:100. Additionally, approximately $\$ 250$ of financial assistance per capita was recommended. Compared to other reconstruction cases, the force levels and financial contributions allocated to Iraq were going to be insufficient. (Jones, et al, 2005: xiii; Edelstein: 2004)

Despite popular belief there was no planning, at least three groups inside the military and one at the State Department worked on postwar issues and produced thousands of pages of documents. According to Army Lieutenant Colonel James Scudieri, the U.S. invasion of Iraq was "the most planned operation since D-Day". But the planning was shoddy and there was no single person or organization in charge. Top officials spent over a year preparing for the attack and invasion, but showed almost casual indifference to what would come later. After nearly 18 months of work, the key question was left substantially unaddressed: what to do after getting to Baghdad? The CENTCOM Commander, General Tommy Franks, apparently believed planning for the end of the war was someone else's job. In his autobiography, he refers to sending a message to Rumsfeld's subordinates stating, "You pay attention to the day after, and I pay attention to the day of." (Franks, 2005) 
On January 20, 2003, a mere two months before the scheduled launch of the war, the President signed a National Security Policy Directive (NSPD) setting up the Office of Reconstruction and Humanitarian Aid (ORHA) to plan and execute postwar policy. Retired general Jay Garner was appointed to lead it. Yet on March 10, just ten days before the attack on Iraq began, the National Security Council was still discussing postwar policy in terms of broad questions, rather than operational details: how many Baathist bureaucrats should be removed, whether existing police and courts could be used by the incoming administration, whether the Iraqi currency should be replaced, etc. (Barnett: 8) Conrad Crane, an Army historian who later studied the record of the planning for the war, concluded the establishment of ORHA so close to the beginning of the fighting simply came too late to be helpful. He determined it created more confusion than coherence because it cut CENTCOM out of the loop. (Ricks: 81)

After the war, Secretary of State and retired general Colin Powell said, "I have no idea what CENTCOM was planning, and I have absolutely no idea what the Joint Chiefs of Staff were planning." Senior State Department officials believed Iraq could not easily be reshaped, given its history of sectarian violence. Replacing its totalitarian regime would require a mission of enormous scope carried out over a period of years, but a different view of regime change evolved within the Defense Department. From the outset, Rumsfeld anticipated power would be rapidly transferred to an interim Iraqi government. The interplay between these two competing visions fundamentally shaped the process of war planning. (Bowen, 2009:1) ${ }^{60}$

In the months leading up to war, Congress asked very few questions and didn't offer any challenges to the administration on the lack of postwar planning. During hearings in February 2003, it did not object when it received answers that did not address the issues. After the hearings, then-retired General Zinni asked an officer at CENTCOM whether the Desert Crossing plan-the one prepared in the

\footnotetext{
${ }^{60}$ Stuart Bowen, Jr. was the Special Inspector General for Iraq Reconstruction (SIGIR). His work reviewed the Iraq reconstruction experience from mid-2004 to late 2008 based on a congressional mandate to provide "advice and recommendations on policies to promote economy efficiency, and effectiveness in programs created for Iraq."
} 
late 1990s for dealing with the end of Saddam's regime-was proving helpful. The senior officer had never heard of the plan. (Ricks: 85-87) CENTCOM had instead spent months updating the 1991 OPLAN 1003, resulting in the final OPLAN for Operation: IRAQI FREEDOM, OPLAN 1003v, in August 2002. This plan envisioned the combat operations phase to last up to 135 days and called for the deployment of about 105,000 troops from all the services. Phase IV: Post-Hostility Operations, would "continue until end-state objectives are met”. (Franks, 2005: 366) The major tasks of Phase IV would include establishing a new Iraqi army and creating a constabulary inclusive of all tribal, religious, and ethnic groups (Id: 400).

Also in August 2002, a top-level meeting under National Security Advisor Condoleezza Rice agreed upon a NSPD entitled, "Iraq: Goals, Objectives, and Strategy". The document laid out postwar objectives in highly generalized terms: "to establish a broad-based, democratic government...that would respect the basic rights of all Iraqis and that would adhere to the rule of law". According to the directive, the United States, in collaboration with the international community, was "prepared to play a sustained role in post-Saddam Iraq that rapidly starts the country's reconstruction and preserves but reforms the current Iraqi bureaucracy". However, when it came to the means of implementing these objectives, the NSPD merely referred to the "Iraqi opposition" to Saddam, meaning the exiled politicians in Chalabi's group. (Barnett: 6)

\section{Iraq: Combat Phase}

The assumptions relied on when planning the military campaign were: 1) the combat phase of the operation would be decisive and produce a stable security environment; 2) U.S. forces would be greeted as liberators; 3) Iraq's government ministries would remain intact and continue to administer the country; and 4) local forces would be capable of providing law and order (Keifer: 22-23). As a result, there was no postwar plan for Iraq that could be implemented by the commanders and soldiers on the 
ground once they reached Baghdad. The State Department, the Pentagon, and the $\mathrm{ClA}-$ without coordination and without consulting previous cases-produced various plans for reconstruction (Feith, 2008: $\operatorname{Ch} 8,9)^{61}$.

The "means" selected to accomplish occupation and reconstruction were assembled under two headquarters: ORHA, under Garner, and the Coalition Joint Forces Land Component Commander (CFLCC), a military officer. ORHA was directly subordinate to CENTCOM, as was the CFLCC, but there was little-to-no contact between the organizations. ORHA was intended to be largely a civilian organization, but many of its early members were military because U.S. civilian agencies were hesitant to provide staff. ${ }^{62}$ Garner and his staff did not arrive in Kuwait until three days before the combat phase began. Due to the lack of communication, neither unity of command nor unity of effort existed between Garner's staff and the military. (Keifer: 23-24) Despite this, the Unified Mission Plan drawn up by ORHA staffers during their short time in Kuwait was surprisingly clear-eyed. It stated, "The most probable threat will come from residual pockets of fanatics, secessionist groups, terrorists, and those who would seek to exploit ethnic, religious, and tribal fault lines." Yet, at the same time, Garner had a short-term conception of his task: he seemed to believe he simply faced a larger version of Provide Comfort, the 1991 relief operation in Northern Iraq. When Garner was told he would need a large and well-designed information management system, he said, "If it's not useful in two weeks, we don't want it. Our time is short, and this job's going to be over quick." (Ricks: 107)

The execution of the combat phase was a complete success, lasting less than 30 days. On May 1 , 2003, President Bush formally announced the end of major combat operations to the world, which officially began Phase IV of the operation for CENTCOM. Combat ended much earlier than expected and

\footnotetext{
${ }^{61}$ Douglas Feith was Under-Secretary of Defense in 2003.

${ }^{62}$ Many civilian employees within the DoD and Department of State simply refused to go to Iraq, even to the point of resigning their posts. Those ultimately willing to go were often less-experienced and hoped to use serving in Iraq as a "bargaining chip" for better positions in the future.
} 
the enablers for Phase IV were not yet in place. ORHA was still understaffed and underfunded, with fewer than 200 officers and technical experts. (Franks: 442) It was slow in getting organized and there were no military government detachments following the invasion forces as there had been in World War II. Plus, the Iraqi Army did not surrender in units as anticipated; rather, the soldiers simply took off their uniforms and went home. This meant the Army was not available to be put to work rebuilding the country. Similarly, the police forces vanished into hiding or retreated to their homes, fearful of retaliation from the populace for 30 years of brutality under Saddam's regime. The civil servants of the government who ran public works, oil production, public health, education, and telecommunications also remained home, and there were insufficient numbers of coalition troops to accomplish this myriad of tasks. The problem was exacerbated when Franks and Rumsfeld halted the deployment of additional troops once the coalition forces reached Baghdad. In 2003, the height of coalition troop levels in Iraq was only 160,000 . This was in direct contradiction to Franks' earlier plans for the occupation and his troop level estimates. As a result, there were fewer troops per capita in Iraq at the beginning of Phase IV than there had been in previous less destructive and less invasive occupation operations (Keifer: 24$25)^{63}$

Conditions did not improve rapidly enough in the month of April for President Bush and the administration, so the timeline for the establishment of the Coalition Provisional Authority (CPA) was accelerated. The CPA was intended to "oversee reconstruction efforts and the process by which the Iraqi people build the institutions and governing structures that [would] guide their futures". (McCreedy: 9) By May 11, 2003, Garner had been replaced by Ambassador Paul Bremer. The war was barely a week old, and there had already been a major shift in post-occupation policy. Bremer also had little time to prepare and the CPA offices remained inadequately staffed. Bremer knew the Allies in World War II had enjoyed much more time to plan than he and the rest of his CPA staff were given. On the other hand,

\footnotetext{
${ }^{63}$ Bosnia and Kosovo, for example, were semi-permissive entry operations that were far less destructive.
} 
useful information related to the German and Japanese occupations was available to CPA personnel during the spring and summer of 2003 , as well as a RAND Corporation study comparing the occupations of Germany, Japan, Somalia, Haiti, Bosnia, Kosovo, and Afghanistan. The study showed democratic nation-building would be possible so long as the U.S. contributed sufficient personnel and financial resources. (Maulucci, 2008: 122, 126).

\section{Summary}

In combat, outcomes are determined by interactions and judgements made independently on both sides; occupation, though, is consistently and primarily a unilateral decision-making process. In fact, it could be argued that administering occupied territory is less difficult than running a domestic government, because the population does not have to be consulted. The authority of the occupying power is complete, with an army to support it. In the post-World War II occupations, one agency (the War Department, later the Department of Defense) ran the military occupations until they ended, and one office was in charge of both military and political affairs, allowing for a unified policy on the ground, regardless of bureaucratic infighting back in Washington. (Zeimke: 444) This stands in stark contrast to the situation in Iraq.

At the highest level, it was unclear whether Iraq's occupation was to be a military operation or a diplomatic effort. Bush assigned post-war matters to the Defense Department, then appointed Bremer-a former ambassador who was subordinate to the State Department-to lead the CPA. According to Bremer's papers, he most frequently reported to Condoleezza Rice in the NSA, not Secretary of State Colin Powell or Donald Rumsfeld. The planning for Iraq's occupation called for a six to twelve month occupation to restore order, contain a humanitarian crisis, rebuild the economy, and create conditions necessary for democracy. The lessons of Germany and Japan should have educated planning officials this was extremely optimistic. Both Germany's and Japan's occupations were initially 
believed to last several months, at most; each lasted seven years, and within weeks U.S. forces were consumed with administering the day-to-day affairs of the population, despite their two years of preparation. (Jennings, 2003: 9) In Iraq, the U.S. neglected pre-war planning and preparation regarding how they would conduct the post-war occupation. Years of work and research on earlier plans were cast aside in favor of seemingly more efficient, less costly ones that would prove to be completely ineffective. The consequences for this lack of regard for post-war efforts would become devastatingly clear by the summer of 2003.

Planners for the fall of Saddam actually had five times longer to prepare for Iraq's occupation than the Allies had in 1945. In 1991, it was noted the loss of the regime in Iraq would be a devastating power vacuum. Detailed plans were developed nearly five years before combat began; military officers in Germany and Japan had barely two years. Even at the extreme, U.S. officials had seven monthsbased on the fact the NSPD dealing with Iraq was released in August 2002-before the fall of Baghdad in March 2003. Yet, at the end of those seven months, the key question as to who would administer the country was still unanswered.

It should be noted, however, that the length of time planners were given is irrelevant, despite the attention it is given by occupation scholars. This work draws focus to a far more important issue: it did not matter how much time Iraq planners were given, because they were preparing for the wrong war. It is an old adage that an army always trains for the last war it fought; this seems glaringly so in the case of Iraq. The Iraq invasion plan called for a quick defeat of the military, just as happened in 1991, with no idea how to actually secure the country (because, in 1991, this was not necessary). This factor, far more than any of those discussed in the previous two chapters, had a profound impact on the occupation's success. In fact, this factor had a significant impact on several Hybrid Factors, such as Security and Civil Institutions. Even key assumptions, such as the Iraqi military surrendering by unit, 
were illogical, since U.S. troops moved quickly through the country and left Iraqi military installations unsecured. Who were the Iraqis supposed to surrender to, if no occupation officials were nearby?

\section{Approach to Civil Affairs}

\section{Germany: Military Government}

Until the summer of 1943, President Roosevelt was convinced occupation government was a civilian job. He proposed dual lines of authority and the establishment of an interdepartmental policy committee to give central direction to U.S. operations in occupied areas. Events eclipsed Roosevelt's preference, however, and he realized it would be necessary to establish military government units to provide men and resources. Only the Army had the ability to make this happen. (Zeimke, 1975: 18) The Army knew, however, if it could not produce enough officers to accomplish the mission of occupation, other government agencies would try to fill the gap with a separate chain of command, making it more difficult for theater commanders to control their area of operations (Keifer, 2009: 5-6). In December 1943, General C.A. West, Chief of Staff for the Supreme Allied Commander, issued the most important document on civil affairs produced until that time: "Standard Policy and Procedure for Combined Civil Affairs Operations in Northwest Europe" assigned full responsibility for civil affairs and military government to the military commanders on the ground. (Id: 9-10)

In early 1945, General Eisenhower named General Lucius Clay to oversee military government operations in Europe. The military made little effort to bring in other potential players, such as Treasury and State, to determine the best way to meet its goals. Gen Clay met only with the Army Chief of Staff and the Secretary of War regarding instructions for postwar occupation. He recalled later no one advised him as to the State Department's role or relationship in the process. (Clay, 1950: 6) According to 
a directive given to Eisenhower by the Combined Chiefs of Staff ${ }^{64}$, control of administration in enemy countries would be referred to as "military government", rather than "civil affairs". Military government would extend over all parts of Germany, including Austria, and would have supreme legislative, executive, and judicial authority in the areas occupied, but the units would rule through existing German administrative structures. In order to exercise this rule, detachments were installed in each local government headquarters within Germany. These detachments laid down policy and issued instructions to senior German officials, appointing new ones when necessary. (Barnett, 2005:13-14)

The Supreme Headquarters, Allied Expeditionary Force (SHAEF) issued every unit a "Handbook of Military Occupation", which provided a single source for every issue they encountered while occupying every city and town in Germany. The handbook included plans for establishing governance, disarming troops and police, handling allied POWS and displaced persons, controlling German telecommunications, conducting intelligence, and understanding their authority as an occupying force. (Keifer: 16) An additional handbook, focusing on government, was issued to higher-level commanders. It contained more detailed instructions, including initial proclamations, laws, and ordinances. Functional chapters included civil administration; denazification; finance and property control; legal, public health, labor, education, and religious affairs; food distribution; industry; communications; and transportation. The manual also contained a checklist to enable military government to function effectively. (Id: 17) In the immediate post-war period, the Western Allies pursued nation-building in Germany by demobilizing the German military, holding war crimes tribunals, helping construct democratic institutions, and providing substantial humanitarian and economic assistance. By V-E Day on May 8, 1945 , the military government carpet was laid in dimensions larger than any plan had contemplated. ${ }^{65}$

\footnotetext{
${ }^{64}$ The Joint Chiefs of Staff, as we know them today, did not become an entity until the National Security Act of 1947.

65 There were approximately 11,500 military government personnel in Germany in September 1945, but only 3,000 remained one year later. (Keifer: 17)
} 
Although the Nazi government and the fighting had ended, military government command was still entirely within tactical channels. After their long winter's wait, the detachments were in Germany and working, though not yet exercising the regional supervision for which they had been designed. Military government operations, with few exceptions, were being conducted as they had been during the combat phase: work was done by the local detachments under the supervision of the tactical commanders and sometimes in competition with the security troops. In two directives affecting the entire U.S.-occupied area, troops were authorized to re-uniform the German police and reopen the lower courts. Policemen could not be armed, but could carry nightsticks, and the courts were allowed to begin clearing out the backlog of ordinary civilian and criminal cases accumulated before the surrender. 25 German courts were operating by the end of May. (Ziemkie, 1975: 269-70) By July 1945, over 200 local German authorities were functioning again (Barnett: 13-14).

The August 2, 1945 Potsdam Declaration ${ }^{66}$ was the first official knowledge the German people had of the Allied plans for their future, and it was a stunning blow. Vast territory was lost, factories would be dismantled for reparations, and the country would have to support millions of additional Germans about to be expelled from Poland, Czechoslovakia, Austria, Hungary, and Romania. (Ziemke: 344-45) The situation's combined factors of occupation, demobilization, and redeployment of U.S. troops to the Pacific made Germany rife for confusion and disorganization. Nine months after V-E Day, only ten divisions and several independent regimes remained for occupation duties, but this was still a formidable force with the numbers to effectively conduct occupation tasks. The Control Council remained a negotiating rather than a governing body, capable of enacting legislation, but dependent on the separate zonal authorities for enforcement.

\footnotetext{
66 Though mostly known for concluding the terms for Japan's surrender, the Potsdam Conference lasted until August 2, 1945. Its last order of business was the plan for post-war Germany.
} 
The final transition from tactical control to military government occurred in the U.S. zone on January 1, 1946, when General Clay assumed complete control of military government as the Commanding General, Office of Military Government, U.S. Zone (OMGUS). Security was established, occupational control was centralized, and there was unity of effort and command; it was time to begin nation-building and the eventual re-establishment of German sovereignty. The balance needing to be found was that between a victorious army living in a conquered nation and an army becoming increasingly concerned for the welfare of its former enemy. Although the planning at least as far back as early 1944 envisioned indirect control through German agencies, military government became functionally locked in at all administrative levels. By November 1945, nearly every detachment was providing some direct services. Army utility experts were restoring gas services out of use since the summer of 1944. Others used horse-drawn carriages to simulate streetcars, successfully transporting 400,000 people a day. (Zeimke: 396-97, 441-42)

\section{Germany: Public Relations Issues}

The area in which the most serious imbalance existed in the spring of 1946 was housing requisitions. Every military government office complained there was an inverse ratio between the redeployment of troops and the number of rooms occupied by U.S. personnel. Clay expressed surprise that after a reduction from more than three million troops to less than 500,000 the Army was still requisitioning houses. The problem was the Army was now living in smaller groups. Military government

was authorized to act as a "buffer" between the communities and the tactical commanders, empowered to prevent property from being taken, particularly from those Germans working for the Americans or those who had put great personal effort into repairing their homes. (Id)

Most of the detachments agreed upon two major complaints: the ceaseless demands from higher headquarters for reports and the not-unfounded belief they were the last to know about major 
decisions. Too often, Germans would hear news on the radio before any official word reached the detachments. This was largely due to the OMGUS requirement to coordinate everything through proper channels, but it did little to help the Americans' image. (Id: 398-99) Typically, military government did not lack critics in the summer and fall of 1945, either at home or abroad. Reports maintained officers were timid about inconveniencing the Germans and were more concerned about getting communities working again than in caring for displaced persons. By October, the Army was completely on the defensive, feeling torn between public opinion and what they felt truly needed to be accomplished. Byron Price, who had been Director of Censorship and former executive editor of the Associated Press, surveyed the "general subject of relations between the Armed Forces of Occupation and the German people". After ten weeks in Germany, he submitted a summary of what he had observed in regards to occupation accomplishments and a review of the problems ahead. He concluded, "taken altogether, it seems to me a notable record of progress...no one who knows the facts can fail to give General Eisenhower, General Clay, and the staff of military government his continuing confidence and commendation." (Id: 400)

An additional strain on the detachments was a rise in violence of all kinds (except resistance to occupation authorities) in the early half of 1946. Military government detachments and the U.S. Constabulary were reporting U.S. troops as the chief source of disturbances within the zone. Incidents actually caused by U.S. troops were no fewer than they had been in 1945, and included wanton killing, looting, threats, and assaults on German police and civilians. What went unmentioned was the coincidence of the rise in troop incidents with the hardening of official attitudes towards Germans. Attacks by Germans on American soldiers-almost unheard of before-were increasing, mostly because of fraternization between soldiers and German women. (Id: 422, 424, 437)

Three days before he departed to assume his appointment as Army Chief of Staff, Eisenhower told the troops the conduct of a "relatively small minority" among them could give the U.S. forces "a bad 
reputation that will take our country a long time to overcome". While Eisenhower was no doubt right the troops involved were a minority, reports and other investigations showed the nature of the misconduct was more serious than he implied. After V-J Day, particularly, there appeared to be a nearepidemic of unprovoked attacks on German civilians, and robberies by U.S. soldiers had spread across the zone. By April 1, 1946, troop shipments out of theater still exceeded arrivals by far, and the reinforcements coming in were mostly recent draftees with only minimal training. Thus, though the number of troop incidents improved in the spring of 1946, the rate of incidence was still high relative to troop strength. (Id: 421, 442) Yet despite these negative behaviors, the Army protected and restored Germany's art treasures and monuments, imported three-quarters of a billion dollars' worth of relief supplies, returned millions of DPs to their homes, cared for millions more concentration camp inmates, and put vital services back into operation, all within one year.

Japan

In Japan, the lack of U.S. personnel with both language and technical capabilities led to the decision to retain the existing government and give occupation authorities a supervisory role (Dobbins, et al, 2003: 39). There remained an asymmetrical relationship between white victors forcing their vision of the future on the defeated yellow race. This racial differentiation enforced by the Occupation had a negative impact on the acceptance of the occupation by the Japanese, and initially created resistance to the transition to a democratic way of life, which was shameful and unacceptable to the existing Japanese political and civil society. Early on, however, references to racial differences were replaced by an emphasis on cultural similarities between the U.S. and Japan. The Occupation began insisting if the Japanese would embrace democratic American values, they could enter the Western family of democracies and benefit from a status of honorary "white" nation. Thus, the Occupation managed to 
win the hearts and minds of the Japanese people, and American values and versions of liberal democracy were embraced without further significant resistance. (Bridoux: 174)

In both Germany and Japan, sufficient U.S. forces were on the ground to micromanage the dayto-day affairs of millions of people. Military governance in Japan was indirect because of communication difficulties, whereas in Germany it was direct due to the absence of German authority. Both occupation governments were thought to be necessary for only a few months at most, but they each lasted seven years. (Barnett: 25) The War Department recognized early that civil affairs/military government is a specialized function requiring specially trained personnel (Zeimke: 448). In 1958, however, the military merged its doctrinal manuals and the focus shifted to bureaucratic concerns and unit composition, rather than how those units should be employed. Civil affairs gradually became a mission to work with existing governments, in whatever form they may be; little attention was paid to circumstances where no functioning government was present. By 2000, the Army's basic manual dropped all reference to military government and the loss of the doctrine was complete. (Keifer: 18-19) ${ }^{67}$

Iraq: Leadership and Staffing

In the last half of the $20^{\text {th }}$ century, both the Departments of State and Defense expressed institutional resistance to nation-building, with neither of those organizations regarding reconstruction as one of their core missions (Dobbins, et al: xxviii-xxiv). The U.S. military now spends far more time refining their war-fighting skills than learning how to work with civilians and civilian institutions. Before the invasion of Iraq, many nongovernmental organizations and outside experts with experience in reconstruction pushed to have occupation authority based in the State Department (Diamond, 2005:

\footnotetext{
${ }^{67}$ This fact is supported by the author's personal experience. In 2005, one of her co-workers (an Air Force attorney) was selected for training in the Army's "new" civil affairs course. It became apparent the Army was not prepared (or, perhaps, willing) to conduct this training, as a proposed three-month course took nearly a year to complete, with most of the listed subjects never covered. The attorney deployed to Iraq and began civil affairs work with no clear understanding of what his role would be.
} 
29), but on January 20,2003, President Bush assigned responsibility for conduct of postwar operations to the Defense Department (McCreedy, 2004: 6). It would be the first time since World War II the State Department was not in charge of a U.S.-led post-conflict situation. ${ }^{68}$ While this was a good step towards enabling unity of command in Phase IV, the senior leadership of the Defense Department did not make an effort to collaborate with other departments for their expertise or to ensure coordination and unity of effort. The other departments maintained a "hands off" approach, believing it was now the Defense Department's show. (Diamond: 29; Beneshel, 2008: xxi)

As Secretary of State, Colin Powell agreed civil affairs organization should come under the Pentagon's authority and be part of the military chain of command-as it had been in the Second World War. He sent two expert advisors on Arab affairs from the State Department who had studied the likely postwar problems in Iraq to assist the DoD in its efforts. These men were summarily thrown out by Donald Rumsfeld, who appointed Under-Secretary of Defense Douglas Feith to oversee planning. Feith was a university trained intellectual, but was not admired by practical soldiers like General Tommy Franks, Commander of U.S. Central Command (CENTCOM), the ultimate military authority in the region. (Barnett, 2005: 7-8) Policy guidance gradually emerged, but Feith maintained tight control because of political sensitivity within the Pentagon and a rift between Rumsfeld and Powell. Conflicting assumptions led to the military's belief civilian departments where going to accomplish reconstruction tasks and the civilian agencies thinking the military would do them. (Keifer: 21-22) No one at the higher levels of these agencies was given-or asked for-clear, explicit guidance on who would be responsible for post-war Iraq.

Despite the lack of active civil affairs training within the military, previous occurrences offered several positive and negative lessons on appropriate policy and behavior during a period of military

\footnotetext{
${ }^{68}$ Interestingly, though, World War II is perhaps the most successful nation-building effort in history, and it was led by the military.
} 
governance. These lessons included avoidance of suspecting all Iraqis were criminals and establishing clear policies for civil-military interaction regarding relief and development initiatives. (Jennings: 6) Neither of these guidelines would be met; instead, quickly-implemented training lacked any history of the war or coalition policy. There was no review of past or current reconstruction projects, no information on civilian organizations or structures, no lessons learned from previous efforts, and no clear description of what civil affairs unit were expected to accomplish. (Barnett: 14) Most importantly, there was no instruction on Iraqi culture and its values.

Every office in Iraq was understaffed during the summer of 2003, despite the soaring numbers of Americans that continued to arrive. The scale of what the coalition hoped to achieve-imperial occupation to remake a country with an (assumed) deadline of six months-was daunting, even absurd. A number of senior Army officials did not think there were enough troops in the country, and many complained about a lack of resources. It was commonly felt tens of thousands more boots on the ground were needed to secure every neighborhood, road, and facility within Iraq. (Diamond: 91, 98, 241-42) But it was not just about the number of troops; it was also about the right mix of forces. There was a need for more military officers with experience in civil affairs and more police trained for crowd control. There was hope some of these forces could come from quickly-trained former Iraqi Army and police units, but there was a general feeling their training had been woefully ineffective. ${ }^{69}$ The training of the Iraqis in 2003 and early 2004 was heavily criticized by the U.S. military, particularly in Special Forces (SF) circles, whose soldiers were better educated than most and trained to be culturally aware. Foreign Internal Defense (FID) is a classic SF mission, but in Iraq, private contractors and members of the conventional military carried it out. SF officers also criticized using Iraqis to conduct raids and other

\footnotetext{
69 In May 2003, President Bush sent former NYC Police Commissioner Bernard Kerik to Iraq to oversee the development of the new Iraqi Security forces, but it was widely regarded his tenure at the Ministry of Justice was a disaster. In 2010, Kerik was sentenced to 48 months in prison following a guilty plea to charges he accepted hundreds of thousands of dollars in illegal gifts and services while working for the City of New York.
} 
direct-action missions, which they felt came at the expense of training and were counterproductive. ${ }^{70}$

(Ricks: 368)

Iraqi police were outgunned by the criminals, severely short on radios, dispirited, and so poorly vetted they included large numbers of criminals and insurgents. By the spring of 2004, there was still no capacity for higher-level police functions, such as criminal investigations. The U.S. military requested to take over the training of Iraqi forces, but Bremer refused to let them, desiring to continue using private contractors instead. (Diamond: 306)

\section{Iraq: Security Contractors}

Security contractors in Iraq had two high-profile tasks in 2003-04. The first was training Iraqi forces, which was nonsensical at times, ranging from rote simple drills to over-the-top complex theories that were a struggle for the many non-literate Iraqis making up the enlisted corps of the Army or the police force. Eventually, training Iraqis was viewed as the worst duty in the country, as many coalition members came to see them as sloppy and ill-disciplined (Van Buren: 43-44). The near-mutiny of an Iraqi army battalion in the spring of 2004 underscored how badly things were going. Subsequent reviews by Army experts found the training had been a numbers game, placing greater emphasis on quantity of soldiers trained rather than the quality of the training ${ }^{71}$. It especially faltered in developing a chain of command-there was still no Iraqi military leadership trusted by both the common soldier and U.S. advisors. ${ }^{72}$ (Ricks: 372 )

\footnotetext{
${ }^{70}$ At first, SF opinions were a minority view, and seen as barely patriotic. By the end of 2004, as the war dragged on, their views gained a new respect. By 2005, they would become almost the conventional wisdom.

${ }^{71}$ Most contracts were based on the number of soldiers trained, though it was expected they would be trained to certain levels of proficiency, which was not the case.

72 The initial training was conducted by Vinnell under a one-year contract valued at \$24 million. When CENTCOM observers determined the training to be unsatisfactory, the contract was terminated. (Ricks: 372 )
} 
Security contractors' second main task was providing security for high-level coalition officialsnamely, civilians within the CPA. Fundamentally, this mission was different from the military's-they were hired to "protect the principal", but had little stake in actually pacifying the country. (Indeed, a peaceful Iraq would mean their services were no longer needed.) They frequently ran pedestrians off the road, used firepower to clear the streets for convoys, and generally treated locals as expendable. They amounted to a small, private army existing outside the U.S. chain of command and not subject to U.S. military discipline or law. ${ }^{73}$ The Iraqis saw all the Americans as part of the same team, however, so contractor transgressions reflected badly on the occupation as whole. (Ricks: $370-71$ )

Civil affairs doctrine asserts there are several ways to make friends in a reconstruction project, but most of them are slow and difficult, such as building relationships based on trust within the local community. But the coalition was not prepared to wait that long, and turned instead to handouts and short-term humanitarian assistance. Troops then waited in vain for a groundswell of appreciation that would cause locals to provide intelligence about insurgents, but the giveaways merely reminded Iraqis of Saddam's clumsy attempts to buy love. ${ }^{74}$ (Van Buren: 115-16)

Many of the Iraqis who worked for the CPA were under-utilized and under-appreciated, but fiercely committed to their jobs. An Iraqi doctor earned approximately $\$ 100$ per month, while the CPA paid nearly four times as much for translators. But those working for the CPA often had to hide this fact or their lives would be in danger. Insurgents knew the U.S.'s ability to work in Arabic was a weakness, and they regularly harassed, threatened, and murdered Iraqi translators. These individuals were torn between the desire to serve, the need for income, and the fear of death. (Diamond: 98) As a result,

\footnotetext{
${ }^{73}$ The Military Extra-territorial Jurisdiction Act (MEJA) was passed in 2000 (18 U.S.C. 212) and intended to allow for prosecution of civilians who commit crimes "while accompanying the force" outside U.S. territory, but it has rarely been used. It requires extensive cooperation of a state-side U.S. Attorney, as well as investigation, evidence collection, and witness testimony from the location of the crime.

${ }^{74}$ One forward-operating base was actually a cement factory before the coalition invaded, and it was appropriated because the Army needed space. Then an elaborate ceremony was held to "gift" the facility back to the citizens. (Id: 29)
} 
there was always a shortage of qualified translators and interpreters. Iraqi-Americans who had not lived in the region for years were used as cultural advisors, some of whom had poor English skills. Others were Kurdish or Christian and did little to facilitate relationships with the Muslim Arab majority. ${ }^{75}$ (Van Buren: 44-45) Most of the Iraqis who worked for the coalition felt a sense of conviction and solidarity with what the CPA was trying to accomplish. They had survived 35 years of Baathist dictatorship and were eager for new opportunities, while at the same time more than able to resist unpopular ideas.

Iraq: Public Perceptions

The 1,000+ officials at CPA headquarters-Saddam's former presidential palace complex inside the already-heavily fortified Green Zone-lived and worked in an artificial bubble. While the layers of security did an excellent job of keeping terrorists out (save for nightly mortar attacks), the fortress also kept coalition personnel barricaded in. Most officials did not venture outside the Zone, and few had contact with any ordinary Iraqis who did not work for the CPA. Policy advisors recommended the United States should disavow any long-term military aspirations in Iraq, since this was one of the fears feeding the insurgency. Two days before the Abu Ghraib prison scandal broke on 60 Minutes, the same advisors also told National Security Advisor Condoleezza Rice the U.S. needed to respond to concerns regarding detainee treatment. (Diamond: 241, 297) The first warning was never heeded, and the second came too late.

From the beginning, advisors told U.S. officials it was vital to get more money flowing to Iraq in order to pay government employees and security officials on time. In March, just before the war began, Secretary Rumsfeld was briefed by Barbara Bodine, a former U.S. Ambassador with extensive experience

\footnotetext{
${ }^{75}$ When the author was in Iraq in 2008, shortage of interpreters was still a problem, particularly those able to read and write, as well as speak, English and Arabic. The effect was significant enough that Kurdish linguists were used in central and southern Iraq, though the two dialects are quite different. The result was oft-misinterpreted court hearings and even more frequent disagreement on the proper translation of testimony.
} 
in the Middle East and the newly appointed coordinator for central Iraq within Garner's ORHA. Bodine explained there was an urgent need to ensure Iraqi civil servants were paid in the aftermath of the war so government services could continue and opposition to the occupation could be preempted. Rumsfeld insisted it did not matter whether Iraqis got paid, claiming they could wait two weeks or two months; what mattered, he insisted, was the American tax-payer would not stand for using tax dollars to pay Iraqis. (Id: 31, 241) Bodine was later relieved of her position when Bremer took over the CPA.

In the face of increasing-and sometimes devastating-violence, Bremer tried to focus on "the swelling tide of goods news" beneath the surface: a water main repaired, the restoration of a sewage treatment plant, the re-opening of four public health clinics, distribution of math and science textbooks, and so on. But these were mere fragments of progress in a country falling apart, and in many cases simply restored things to the status quo prior to the invasion. Increasingly, the Americans were held responsible for the failure to provide security. The UN was authorized to have further discussions with the insurgents, a clear indication these groups were more resourceful, sophisticated, and coordinated than initially believed. Though they were willing to talk, nothing ever came from these inquiries, however. U.S. officials were skeptical the Iraqi groups acting as facilitators would truly be able to reduce the violence, so the Iraqis never received the direct negotiations they were seeking. (Id: 47, 79) Lack of progress on the security front impeded the implementation of programs aimed at spreading democratic ideals and values. The attempt to liberate the press ended with the censoring of local newspapers when they became too critical of the occupation. This led the Iraqis to turn to panArabic channels to obtain information about what was happening in their own country. (Bridoux: 17273) Even Americans inside CPA headquarters often had to call home to the States to ask friends and family members about incidents less than a mile from the palace. Teams were at work around the country trying to refresh the provincial and local councils-consulting with each community to purge the councils of unpopular, corrupt members and make the groups more representative and acceptable, but 
much more needed to be done to strengthen the elements of the new fledgling democracy. (Diamond: $77,92)$

It would take years for the Americans to realize they needed to provide services like garbage collection and potable water before everyday citizens could focus on governance. The invasion had begun a process of devolution, where populated areas within Iraq lost their ability to sustain the facilities to conduct this work. America's "shock and awe" campaign disrupted the network infrastructure that allowed cities to function. Under Saddam, there had been a slow degradation through neglect; under the Americans, there was an irreversible decline. It would take the coalition too long to understand the provision of basic utilities was critical to its counter-insurgency efforts. First, mega-contractors like Bechtel, and later the Army Corps of Engineers, would attempt to address these issues; both would fail. (Van Buren: 56)

Iraq: Rise of Militias

It is clear that in 2003 the U.S. government was not set up institutionally to manage the challenges it faced in the post-Cold War world. The United States and its coalition partners launched the invasion of Iraq on March 20, 2003. On April 21, the ORHA was established with Jay Garner at its head, and on May 11 he was replaced by Paul Bremer and the CPA. In the 1990s, the State Department coordinated engagement after conflict, but in Iraq-a country many times larger than the conflict-ridden states of the previous decade-the Pentagon was given control. (Diamond: 308) As a subsequent RAND study put it, "Overall, this approach worked poorly because the Defense Department lacked the experience, expertise, funding authority, local knowledge, and established contacts with other potential organizations needed to establish, staff, support, and oversee a large, multi-agency civilian mission." (Ricks, 2006/07: 78-79) These factors caused the American occupation to move away from what was 
planned to a position of reacting to events on the ground, rather than controlling them (Bridoux, 2011: 164).

Within the first few months of the occupation, a number of separate, shadowy underground militias emerged representing various strands of the opposition. They numbered in the dozens and may have brought together over 30,000 men, but they were fractured and episodic in their nature. In time, however, some became more effective in coordinating tactics and strategy. By November 2003, insurgent attacks increased and included sabotage of power, water, and-above all-oil installations. Assassinations of leading political figures, criminal activities like kidnapping, disruption of convoys and killing of foreign forces, and spectacular, random killings of civilians for media attention were also more frequent. The widespread Sunni-Arab insurgency had a mixture of motives. One was obvious: shock and reaction to foreign occupation and rule, accompanied by outrage at de-Baathification and the displacements of Sunni Arab leaders by exiles and opposition elements. Sunnis were also dismayed at the increasingly ethnic and sectarian basis of rule, which seemed to be undermining state unity. (Marr, 2012: 274, 276)

The Sunnis were not the only disaffected group to mount an insurgency. A second major force also emerged during this early period-the Sadrists, led by Muqtada al Sadr, a minor cleric. ${ }^{76}$ This group sought to challenge the coalition and the moderate Shia leaders who were gaining power, thus splitting the Shia movement. Like the Sunni opposition, Sadrists adamantly opposed the U.S. occupation and resented the "exile" leadership the U.S. favored. Neither group was included in the emerging government structure. Sadrists drew from the young and poor in the slums of Baghdad and other cities in the south. In the summer of 2003, Sadr established the Mahdi Army, which became the military arm of his movement. By fall, the Mahdi Army was ambushing U.S. forces. In early 2004, they were taking over mosques and universities in Baghdad, setting up shari'a courts to enforce Islamic law. (Id: 277)

\footnotetext{
${ }^{76}$ Sadr's titled was self-appointed; most legitimate clerics in Iraq disavowed his qualifications.
} 
The insurgency also grew out of mishandled military clashes between occupation forces and the local population. Mosques frequently spouted messages that were a combination of religion and nationalism, urging Sunnis to resist any government while occupation lasted. Militant opposition thus became a religious duty. Another source drew on more locally rooted nationalism, swollen by former Army officers and other newly-discharged veterans of the Baath party and military apparatus. This group not only had the expertise to organize and coordinate armed opposition, but they also had access to weapons, financing, and a deep network of tribal and family ties essential to any underground network. The absence of employment opportunities and services was a major motivating factor for this group, making it easy to employ local youths with no jobs. Finally, foreign fighters-including those associated with al Qaeda-were another source of opposition. Though always small in numbers, these fighters were able to exploit local forces in order to increase their support within Iraq. They espoused a puritan version of Islam previously foreign to Iraq, and they were willing to use harsh tactics to enforce its rule. (Id: 274-275)

Iraq: COIN Failure

It is possible to open counter-insurgency texts at random and find principles the Americans failed to heed in Iraq, especially in 2003 and 2004, simply because no one was connecting the dots. In a counter-insurgency, the battle space is not physical, it is psychological-the battle is for the people. T.E. Lawrence, the British advisor to Arab guerillas during World War I, once defined tactics as, "the means toward the strategic goal, the steps of its staircase." The tactics many U.S. commanders used in Iraq led away from the strategic goal of winning the political support of the people. Supply convoys raced across the countryside to stock large U.S. enclaves while their drivers shot at Iraqi civilians to make them keep their distance. Personal security details for senior CPA officials rocketed through Baghdad, forcing Iraqi cars onto sidewalks. Frustrated combat troops used force first, violating the most important lesson of 
successful modern counter-insurgency (COIN) campaigns: violence should be the last resort, especially for troops foreign to the local population. As a result, local CPA officials frequently clashed with combat commanders, but neither received much direction from higher levels of command. (Ricks, 2007: 225, $250,253,265)$

According to David Kilcullen, a counter-insurgency theorist, "the best insurgent is not a dead one, who might leave behind relatives seeking vengeance, but one who is ignored by the population and perhaps contemplating changing sides, bringing with him invaluable information." Therefore, the civilian population should protected at all costs. (Ricks, 2009: 6-7) But in the first year of the occupation, U.S. forces appeared far more focused on killing and capturing insurgents than on securing populations (Record, 2007: 81). Kilcullen also noted one of the lessons of the twentieth century was there had "never been a successful counter-insurgency that took less than ten years" (Charlie Rose, 5 Oct 2007). Such wars are inherently asymmetric: the war could never be as important to the United States as it was to the Iraqis, who were fighting to determine their future. While the Americans could go home, the insurgents-with the exception of a relatively small minority of foreign fighters-were home.

Counter-insurgency expert lan F. Beckett argues the essentials of COIN have remained fairly constant since 1945 . First, the response should be political, rather than purely military. Second, there should be coordination of the military and civilian response. Third, intelligence should also be coordinated amongst all groups. Fourth, civilians should be separated from insurgents. Fifth, only the minimum amount of force necessary should be used in any situation. And sixth, long-term reforms need to be implemented to address the grievances leading people to support the insurgency in the first place. (Beckett, 2005) Determined insurgencies are difficult to defeat. Where strong actors have succeeded in doing so they have preceded military attacks with political and economic reforms-reforms that isolated guerillas and terrorists from their base of support. (Record: 119) But this approach is not easily mastered by a conventional military force. The Iraqi insurgents were able to force the U.S. into a stalemate and 
maintain daily attacks on their civilian targets without ever achieving a singular spectacular attack, which is why in mid-2003 a professor at the Army War College said, "The possibility of the United States winning the war and losing the peace is real and serious". (Crane)

The insurgency remained all but invisible except during its attacks. It issued no statements, had no visible leaders or spokesmen, no diplomatic offices operating in friendly Arab capitals. All that was really known was its location and tactics: most of the insurgency was in the Sunni triangle in the central part of Iraq, and it was generally low-tech. And, as was written decades earlier about the French war in Algeria, "first comes the mass indiscriminate round-up of suspects, most of them innocent, but converted into ardent militants by the fact of their imprisonment." (Horne, 1977) In the late summer of 2003, senior U.S. commanders tried to counter the insurgency with indiscriminate cordon-and-sweep operations ${ }^{77}$ that involved detaining thousands of Iraqis. By the fall of 2003, this approach swamped the system and undercut the aim of improving intelligence because there were not enough interrogators on hand to detect the genuine adversaries among the thousands of innocent neutral Iraqis caught up in the sweeps. Some detainees were held for more than 90 days before being interrogated for the first time. Between August 2003 and March 2004, one Army division-the $82^{\text {nd }}$ Airborne-detained 3,800 people and shipped 700 to Abu Ghraib. Family members were sometimes taken into captivity to force suspects to turn themselves in, a tactic commanders insisted was not hostage taking -it was intelligence operations. (Ricks, 2007: 195, 224, 236, 238)

By conducting raids and sweeps, kicking down doors (often the wrong doors) in the middle of the night, entering the private space of the house where women and children were present, then tying

\footnotetext{
${ }^{77}$ Through their lack of discrimination, cordon and sweep operations tend to have powerful unintended, negative political effects on the population. Not only do they alienate those affected, but they show the military forces conducting the operation are ignorant about who is neutral and who is hostile. "This does two things", concluded a 2005 study by Hicks \& Associates, a small but influential Pentagon consulting firm. "For potential government collaborators, it makes them less sure that the government will protect them from harm. For potential insurgents, it makes them less worried they will be caught."
} 
up and interrogating the man of the house in front of his family, the premier cultural value of family honor was repeatedly (and intentionally) violated by the coalition. One sheik stated U.S. forces created a blood debt with every raid. By late autumn, Abu Ghraib contained nearly 10,000 prisoners. U.S. military officials later estimated most of them were innocent and the vast majority had no intelligence value. One reason for this strange tactical approach was the muddled strategy of U.S. commanders. The emphasis on the use of force and powerful retaliation, while protecting U.S. troops at all costs, tended to push soldiers towards harsh treatment of civilians, especially detainees. (Ricks, 2007: 235-36, 238, 266)

Capitalizing on the detainee insults, the biggest threat to security in the summer of 2003 came from Sadr's Mahdi Army. This movement, drawn from legions of young slum dwellers who saw nothing but oppression under Saddam and saw little more in the way of opportunity from the U.S.-led occupation, constantly maneuvered for position. In late July, while demonstrating in front of a mosque, Sadr's mobs had provoked a group of U.S. Marines into firing on the crowd, enabling them to stir up more anti-coalition sentiment over the next few months. Their shari'a courts continued to operate, signaling a bid to establish an alternative form of government.

But this movement was not just about religious fanaticism; it was also about the struggle to fill the vacuum of power in the country. Sadr and his followers were rising in power so rapidly other political and religious factions began forming their own militias. In the towns and villages of Iraq, practically every male over the age of 14 had some form of gun. By the start of 2004, the entire Shiite south-central region of the country was rife with militias. Though often competing with one another, the major militias soon began showing their willingness to collaborate in offensive operations against those viewed as supporting the occupation. Reports began coming in that militia groups were seizing public buildings, beating up university professors and deans, taking over classrooms and departments, forcing 
women to wear the hijab ${ }^{78}$, setting up more illegal shari'a courts, and imposing their own penalties for perceived violations of Islamic law. The menace of these groups played neatly into the hands of Sunni insurgents, who used these violent acts to turn the Shiite population against the coalition for its "sin of omission" -its inability to protect them from the militias. (Diamond: 211-12, 214-16, 221, 227)

It was not until February 2004 that the CPA developed a formalized plan for dealing with the militias. The "Transition and Reintegration" program called for a decommissioning and disarmament of irregular forces in exchange for a variety of individual and group incentives. ${ }^{79}$ The plan, initially, was to require all forces to disband ${ }^{80}$, but the Kurds were eventually permitted to maintain the pesh merga to uphold security within their region. It was estimated more than 100,000 fighters in various militias would be involved. Millions of dollars would be required for additional job training, including basic education. For the plan to succeed over time, there would also need to be a significant commitment from Iraqi ministries once control was turned over to them. Such support and success was doubtful, since these same measures were touted but never implemented when the original Iraqi Army was disbanded. Additionally, it was widely known the training and establishment of the Iraqi Police had been a disaster, with officers rushed into service poorly trained and with inadequate equipment. (Id: 223, 226-27)

By March 2004, the situation in the south had deteriorated. Sadr's Mahdi Army attacked a village, destroying approximately 150 homes and several shops, leaving more than 1,000 people

\footnotetext{
${ }^{78}$ The scarf worn by Islamic women to cover the hair and, sometimes, the face. An Iraqi female known to the author stated she continued to wear traditional Islamic dress, even in 2008-which she had not done under Saddam-because she received threats for being "too Western" if she did not.

${ }^{79}$ Such demobilization plans are an essential component of any post-conflict reconstruction efforts, as opposition forces are either reintegrated into the civilian economy and society or into the legal armed forces. Much earlier in the occupation, a Spanish commander suggested the coalition should cooperate with the militias and received a dressing-down from Bremer for doing so. At the time, the CPA said the U.S. would not work with illegal organizations and "criminals". Following Bremer's departure, the U.S. military not only began working with militias, but even aiding and equipping some of them.

${ }^{80}$ Since many militia members were former soldiers in the Iraqi Army, this essentially meant the occupation force disbanded them twice.
} 
homeless. A group of survivors were arrested at a militia checkpoint and detained for 10 days in an illegal prison. By the time occupation officials came to investigate, not a single building was left standing. Senior CPA officials knew if all-out fighting broke out in the south, the coalition would be in trouble. Since September 2003, the region had been secured by multi-national forces from Poland, Ukraine, Spain, Bulgaria, El Salvador, and the Dominican Republic-not the U.S. Army. Most of these soldiers did not go to Iraq to fight-in fact, their rules of engagement prohibited the launch of offensive operations-but were now expected to secure an area containing an estimated 25,000 militia fighters. The Mahdi Army and other major militias had obtained numerous weapons from Iraqi army supply depots left unguarded during the invasion. Poorly equipped local officials were eventually forced to surrender more public buildings and assets to them, and it was doubtful the U.S. had enough troops in Iraq to confront every militia at once. When a regional CPA coordinator was threatened with assassination, the CPA simply transferred him back to Washington, but took no steps to bring the perpetrators to justice, claiming the administrator was merely "a target of opportunity". Bremer repeatedly stated he could not get more troops to deal with the situation, as $80 \%$ of all available military police were already in Iraq ${ }^{81}$, and any CPA staffer or civilian contractor who felt unsafe should go home. In fact, the coalition military command had only recently cut the number of American MPs in Iraq by half-a poorly timed decision. (Id: 211, 216, 219, 221, 299)

On March 28, 2004, Bremer ordered the closure of Sadr's newspaper, charging it spread false stories of the occupation and incited Iraqis to violence. Sadr then called for open rebellion against the occupation, and his followers quickly seized control of the city of Kufa and the sprawling East Baghdad

\footnotetext{
${ }^{81}$ The specialization and occupation codes for today's military are far more specific than they were in World War II, when nearly every soldier was used in combat and security. In Iraq, the belief seemed to be a well-trained soldier could not provide security unless they were an MP. The Army and Marines were also deploying in much higher percentages than the Air Force and Navy, even though all branches have their own versions of security personnel. Additionally, an alarmingly high number of military police were needed to man the detention camps, rather than civilian police or prison personnel being recruited for this task.
} 
slum known as Sadr City. Bremer declared Sadr an outlaw and issued a warrant for his arrest, but U.S. officials held off on trying to capture or kill Sadr, for fear of igniting even worse violence. ${ }^{82}$ Sadr continued to capture cities in the south, eventually overthrowing the CPA compound in Kut. Coalition facilities in four other cities soon came under assault, and another fell. Less than a week into Sadr's uprising, one official remarked that six months of work had been destroyed. (Id: 229-232)

Meanwhile, the city of Fallujah was erupting into one of the most gruesome episodes of the occupation. A predominantly Sunni city, Fallujah was a Baathist stronghold under Saddam and had been an operating base of the insurgency for months. In late March, an angry mob ambushed and killed four Blackwater contractors, dragging their burned and bullet-ridden bodies through the streets. The Marines cordoned off the city, causing many residents to rally to the insurgents' cause. On April 5, a battalion of several hundred newly trained Iraqi soldiers refused to join the Marines in assaulting the city. Opposition forces quickly began to see how over-stretched the U.S. forces were. Images of the city showed heroic Iraqi resistance to American aggression, bringing condemnation from many U.S. allies. As reports came in of hundreds of noncombatants being killed and disruption of food, water, and electrical services, Iraq's interim human rights minister resigned, calling the blockade of Fallujah "a clear violation of human rights". Several other members of the fragile Interim Governing Council (IGC) ${ }^{83}$ publicly threatened to quit over Fallujah, and even more members lambasted Bremer for not consulting with them before undertaking the siege, and for ignoring them when they had advised how to deal with Sadr months earlier. On April 9-one year after the fall of Saddam-Bremer was forced to order a cease-fire in Fallujah. The insurgents followed suit two days later. By then, city residents claimed 600 Iraqis had

\footnotetext{
82 In fact, there had been a warrant for Sadr's arrest in connection with the murder of a prominent Iraqi official since July 2003. While the U.S. viewed the warrant as a way to keep Sadr in line, his followers saw the CPA's failure to act as a sign of the coalition's impotence. (Diamond: 224-25)

${ }^{83}$ The membership of the IGC is discussed in more detail in Chapter 15: Elections and Constitutional Drafting.
} 
been killed and the U.S. reported 48 Americans were dead. It was the highest weekly death toll since formal combat operations had ended 12 months earlier. (Id: 232-36)

Once Fallujah was resolved-somewhat shakily - there was still the issue of Sadr and his actions in the south. American troops were forced to stand back for over a week while hundreds of thousands of religious pilgrims flocked to holy cities in the region to celebrate the Shiite holiday of Arba'een. As the holiday drew to a close at sundown on April 11, a battle seemed imminent. On April 12, a delegation of leading Shiite clerics and four grand ayatollahs met with Sadr and convinced him to withdraw his fighters from the cities. No formal deal involving disarmament of the Mahdi Army was ever reached, however. By mid-month, the American death toll reached 70, and the violence had thrown the political transition into crisis while virtually freezing all economic reconstruction. CPA officials and private contractors were now in danger any time they traveled outside of fortified safety zones; supply chains dried up as trucking became perilous; and two major contractors suspended their operations in the country. Thousands of workers were confined to their quarters, unable to repair power plants, water treatment facilities, and other decaying infrastructure. Scores of translators and other local support staff stopped showing up to work. (Id: 236-37)

On April 19, the cease-fire in Fallujah was broken. The U.S. now faced an impossible dilemma: if it invaded Fallujah, it risked massive civilian casualties and a disastrous political backlash capable of completely derailing the occupation and recruiting many more fighters for the insurgency. On the other hand, the security of the entire country and the credibility of the Coalition were on the line. Plans to jointly patrol the city with Iraqi forces were set aside when insurgents, firing from a Mosque, attacked the first group of Marines to enter the city. The Marines responded with heavy air support, toppling the mosque's minaret. The stand-off was finally broken when an American general brokered a deal in which the city would be handed over to a 1,000-man Iraqi militia subordinate to the Marines, allowing the city to be void of an American military presence. Within a month, the security militia retreated to tents 
outside the city and the police cowered in their patrol cars while masked insurgents ran the city. ${ }^{84}$ The Americans believed their presence would be reassuring, but the people of the city-known for a cultural conservatism and xenophobia considered intense even by other Iraqis-found them an insult to their personal dignity, perhaps even to the core value of Iraqi culture. Fallujah quickly became a cause celebre for the insurgency. (Id: 237-39)

April 2004 claimed the lives of 130 American soldiers-more than had died in combat toppling Saddam's regime. Iraqi casualties were much higher, and by no means only from American fire, as the terrorist war continued. By late May, Sadr's forces were finally routed by U.S. troops, largely through the help of Iraqi tribes throughout the south, leaving behind shattered city centers and wrecked local economies. More importantly, Sadr was not required to surrender or disarm, and his militia-though badly defeated-survived to fight another day. ${ }^{85}$ (Id: 242-45)

On June 24, 2004, in testimony to the Senate Armed Services Committee, Deputy Secretary of State Richard Armitage conceded the insurgents had a "central nervous system" exhibiting coordination and effectiveness. Beyond the spectacular strikes, there was a steady onslaught of dispersed attacks, ambushes, and roadside bombs that killed smaller numbers of American and Iraqi soldiers, police, civilians, and foreign contractors on a daily basis. American troops were constantly rotating through the country, creating a trust problem for U.S. forces. During the first year of the occupation, as many as five different units might have been responsible for a city. (Ricks: 139, 142) The lack of trust was compounded by the fact Iraqis were generally suspicious of the police or other security apparatuses;

\footnotetext{
${ }^{84}$ It is interesting to note when the author attended training at Fort Dix, NJ in 2007, a video of our troops in Fallujah was shown with pride as a way to "inspire" those about to deploy.

${ }^{85}$ Feb-March 2008 was the infamous "Sadr City Siege", during which Baghdad's Green Zone was hit with mortars an estimated 17 times per day with multiple impacts during each barrage. The launches originated from across the river in Sadr City. The author was deployed to the Presidential Palace/U.S. Embassy in the Green Zone during this time. At no time were Embassy personnel briefed on who was behind the attacks, or the history involving the Sadr movement; rather, the author and her co-workers received their information from CNN and online newspaper accounts.
} 
they feared any authoritarian organization was still dominated by Saddam loyalists. Every Iraqi had a story about life under Saddam, and most of the tales were horrifying. Consequently, they resisted bringing forth information about insurgent groups out of fear of reprisal. (Diamond: 94, 127)

Iraq: The $101^{\text {st }}$ Airborne - A Counter Example

Despite the occurrences in the southern and central parts of the country, Mosul, the biggest city in northern Iraq, never erupted, though it could have at any moment. It came with a ready-made civil war, hosting some 110,000 former Iraqi army soldiers and 20,000 Kurdish militiamen willing to fight them. It was also the home-base of the Iraqi Islamic party, which had survived Saddam's efforts to crush it, and over-flowed with potential enemies of the occupation-so much so that Saddam's sons, Uday and Qusay, chose it as their hiding place. But the $101^{\text {st }}$ Airborne, under then-Major General David Petraeus, led the most successful counter-insurgency campaign in Iraq in 2003. Their efforts offer a glimpse of how the occupation might have been conducted more effectively. (Ricks: 228)

Petraeus and his planners knew they were in a race against time, conscious that any army of liberation has a half-life connected to it, at the end of which it turns into an army of occupation. What they wanted to do was extend that half-life as long as possible by performing good deeds and spreading word about them. They prided themselves not on successful firefights, but on paying government employees. Faced with the challenges already present in Mosul, Petraeus and his staff devised a strategy based on three principles: first, time was of the essence; second, the real goal was to make as many Iraqis as possible feel they had a stake in the new government; and third, if an operation would produce more bad guys than it took off the street, it wasn't launched. ${ }^{86}$ Thus, the $101^{\text {st }}$ did not practice the same cordon and sweep operations as the rest of the army; instead, they took a "cordon and knock" approach

\footnotetext{
${ }^{86} \mathrm{It}$ is worth noting this population-oriented approach Petraeus and his troops took in Mosul in 2003 would be the one the entire U.S. Army tried to adopt in 2006.
} 
under the theory most Iraqi men, even insurgents, so valued their household privacy they would surrender peacefully rather than subject their families to intrusive nighttime searches. Under this approach, suspects' homes were surrounded and they were invited to turn themselves in. (Id: 230-31)

Another issue Petraeus dealt with was the rumor among Iraqis the night-vision goggles used by American troops could enable them to see through the clothes of women. Hearing these rumors, the $101^{\text {st }}$ put on an exhibition for the sheiks in the area, allowing them to examine and use a variety of military observation and imaging devices. ${ }^{87}$ This type of meeting was repeated and eventually evolved into a formal commission, where soldiers and local leaders discussed regional issues every month. By January 2004, northern Iraq appeared to be in remarkably good shape. There was an average of just five hostile acts a day, including attacks on Iraqis. In contrast, there were 25 meetings a day between division commanders and Iraqi leaders. (Id: 231-32)

Iraq: Misunderstanding the Insurgency

Other commanders took different approaches. Major General Odierno, commander of the $4^{\text {th }}$ Infantry Division, believed artillery played a significant role in counter-insurgency operations, even though this assertion was at odds with the great body of successful counter-insurgency practice, which holds firepower should be as restrained as possible. But such a strategy did not utilize the many technological advantages wielded by the U.S. military. ${ }^{88}$

\footnotetext{
${ }^{87}$ The author had to arrange a similar demonstration for Iraqi judges in 2008. During a case before the Central Court of Iraq, U.S. Army soldiers were testifying about what they witnessed via night-vision goggles. The Iraqi judges were not convinced such details could be observed until they tested the technology themselves. The "test" was conducted by turning off the courtroom lights and having one of the judge's clerks run around the room. ${ }^{88}$ The U.S's strategic position resembled the Soviet Union's in Afghanistan in the early 1980s, when the Red Army, after quickly taking the country, found itself mired down and suffering increasing casualties. When the U.S. went into Afghanistan 22 years later, they were cognizant of this and took steps to avoid repeating the situation. They went in fast and small, rather than big, heavy, and conventionally. In Iraq, however, the Americans repeated many of the Soviets' mistakes and confused swift entry with victory. (Ricks: 301-02)
} 
The strategic confusion about why the United States was in Iraq may have led some American soldiers to treat ordinary Iraqis as if they were terrorists. When faced with rising levels of violence, the Bush administration made the fatal mistake of conflating both Sunni insurgents and al Qaeda terrorists into one group to be dealt with in the same manner. Both had a common objective of ousting U.S. troops from Iraq, but their motives for doing so were quite different. Al Qaeda saw Iraq as the frontline in their holy war against the U.S., while the Sunnis simply wanted to regain their power and position. By identifying Iraq as central to its war on terror-in fact, as its main battlefield-the U.S. legitimized the jihadist fight and pinpointed a location where foreign fighters could converge. (Bridoux: 100) The administration insisted the war was part of the counter-attack against al Qaeda-style terrorism, and was therefore a response to the $9 / 11$ attacks, but most Iraqis were not terrorists-they were just average citizens who, though not necessarily sympathetic to the U.S. presence, were not actually taking up arms against it. (Record: 69, 91) In May 2004, a sheikh in the $4^{\text {th }}$ ID's area of operations told a CPA council that while no one wanted to admit it, the situation in the region was a direct result of coalition excesses over the last several months. The CPA took this as a warning U.S. military actions were eroding the sheikhs' ability control their people. (Ricks: 357)

By fundamentally misreading the nature of the war, American soldiers' interactions with the Iraqi population conditioned the outcome of the reconstruction because it deepened the resentment created by the presence of foreign troops. The lack of cultural sensitivity contributed to a worsening of the negative image of an ignorant and careless occupier. Brigadier General Nigel Aylwin-Foster, a British officer, charged the Americans in Iraq with displaying such cultural insensitivity it arguably amounted to institutional racism and likely spurred the growth of the insurgency. He contended the U.S. military's handling of Iraqis "exacerbated the task it now faces by alienating significant sections of the population". (Foster: 2005) 
Pentagon officials, realizing a greater troop presence might actually do more harm than good at this point, called for a speed-up in the training of Iraqi Security Forces. The hope was ISF could be placed in charge of patrolling the streets and enforcing law and order while U.S. troops performed combat operations, and it was believed insurgents would be more hesitant to attack their countrymen. (Wolfowitz, 2003: 35) Eventually, the CPA produced a series of orders intended to establish a functioning judicial system (CPA 2003e, 2003h, 2003n), but lack of resources combined with the summary detention of thousands of Iraqis-many of them without charge, trial, or legal representation-in American and British-run prisons, damaged any claims the occupation was bringing justice to Iraq.

Further undermining U.S. effectiveness was a lack of institutional memory-a major obstacle in civil affairs work. The CPA heavily relied on a revolving door of diplomats and other personnel who would leave just as they were beginning to develop local ties. With tours of only six weeks (and later, three months) as the norm, it was difficult for CPA staff to get up to speed and produce before they rotated out. This gave Iraqis the impression Americans had changing agendas and were poorly informed. It also allowed them to simply "wait it out" if they disagreed with the current set of coalition advisors. Many CPA staffers were also extremely inexperienced, and were recruited based largely on their willingness to live in Iraq rather than their qualifications or proven competence. Most had impressive academic credentials, but little practical experience, and seemed to hope a stint in Iraq would jumpstart their diplomatic careers. A 24-year old Yale graduate was given the task of organizing the Baghdad stock exchange; a Harvard grad of similar age was a constitutional consultant. Regardless of their level of intelligence, this youthful cadre could not help but offend in a society highly conscious of age and wisdom. (Diamond: 289-90) By June 2004, two-thirds of Iraqis said they opposed the U.S. presence altogether, and an even larger portion thought the presence should be minimized. They were almost unanimous (94\%) in their view U.S. troops should stop conducting street patrols. (Ricks: 367) 
The U.S. turned out to be incorrect in its assumptions about Iraq and lacked a workable concept of operations, completing the job of creating the insurgency. Lt Col Christopher Holshek, a civil affairs officer, wrote that the flaw in the military's approach was once the public began to turn against the Americans, the presence of troops became counter-productive. Yet, as the security situation became more dire, troops patrols increased. In 2003 and 2004, few U.S. officials seemed to understand the centrality of Iraqi pride, and the humiliation Iraqis felt to be occupied by a Western army. (Id: 192)

\section{Summary}

Several criticisms of civil affairs in Iraq are presented above, but all of these observations were obtained through the personal in-country experience of their authors as events unfolded in the moment; no comprehensive comparison was later accomplished, nor did these authors reference previous occupation efforts as a basis for their critique. Thus, all these previous works do is illustrate mistakes that were made, without providing guidance on a clear way forward, or even showing whether such failures were inevitable based on historical events. There is no question the approach to civil affairs in Iraq was a far cry from the steps used in 1945. For example, military soldiers were used to run longterm detention facilities housing thousands of alleged insurgents, rather than recruiting/hiring civilian police officers and corrections personnel to do the job (as was done in dozens of other personnel areas). This method would have freed thousands of military police (who are not routinely trained in detention operations anyway, as tragedies like Abu Ghraib illustrate), for security measures, tasks they ARE routinely trained for. President Bush then appointed a former NYPD Commissioner to oversee the training of the new police force, a man with impressive law enforcement and administrative credentials, of course, but there is no indication he had an extensive background in training. In general, status seemed to outweigh actual and relevant experience in Iraq, and it was useless without capable subordinates to carry out orders. 
In contrast, every soldier in Germany was provided a "Handbook of Military Occupation", with additional governance checklists distributed to higher-level officers. In 2003, the Army did not have dedicated civil affairs officers; training in this field to prepare officers for Iraq did not even begin until 2004-05, far too late to make any appreciable difference, and the appropriate structure for their work was never put in place. Officers were pulled from other job specialties in order to fill billets, and the training was ad hoc, at best, irrelevant at worst. The importance of quality training specifically in civil affairs was shown in Germany, when-even as overall troop levels dropped-the rate of troop incidents against local citizens increased as newer soldiers with less training and experience entered the theatre.

The Defense Department was placed in charge of Iraq's occupation, despite the fact it had not overseen such a campaign since 1945. While the State Department had far more experience, it clearly lacked the manpower and materiel to accomplish the mission. A promising solution seems obvious, but appears to have never been explored: a hybrid operation, under military control, utilizing State Department officials as civil affairs workers while troops provided security. Steps would need to be taken to ensure unity of command, but no work has highlighted why such an approach would not be effective, other than the personality conflicts between Powell, Rumsfeld, Wolfowitz, and other senior officials hindered cooperation at the highest levels, even in a situation as vital as a nation's future.

\section{Occupation Policy Decisions}

\section{Germany: De-Nazification}

Initially, the U.S. occupation forces in Germany focused on demobilization of the vast German army, denazification of German society, and prevention of reemergence of Nazi elements. The Western zones quickly demobilized the German military, with little resistance. The Wehrmacht and all other military and paramilitary organizations were dissolved, and the German general staff was abolished. The Allied Control Council promulgated a series of laws to codify this disarmament and remilitarization of 
Germany (Dept of State, 1947: 13-16; 89-108). The constabulary forces, meanwhile, trained a new German police force soon capable of conducting routine police duties. This allowed the constabulary to focus on border control and law enforcement among the displaced persons. (Dobbins, 2003: 11; Harmon, 1970: 289)

The basic principles of the denazification program were laid out in Joint Chiefs of Staff (JCS) Directive $1067 .{ }^{89}$ These principles focused on dismantling the political and legal structures the Nazi Party created in Germany, arresting and punishing Nazi leaders and supporters, and excluding active Nazis from public life. (Id) Obliteration of Nazism was a major war aim, and JCS 1067 prohibited retaining Nazis for administrative necessity, convenience, or expediency. During the week the war ended, Col Joe Starnes, on a mission for SHAEF, finished a two-week tour of Germany. He had seen more of the country than any other westerner and he reported, "Germany's military power is destroyed. The Nazi party is dead." (Ziemke, 1975: 283) Within a matter of weeks, 2.5 million former members of the Wehrmacht were orderly disbanded and transition from Nazi government to the Allied Control Council was accomplished without any break in operations. (Barnett, 2005: 3) Nearly all members of the Nazi party were dismissed from their civil and military posts within six months of the start of U.S. occupation. (Jennings, 2003: 35)

Initially, SHAEF set 1933-the year of the Nazi takeover-as the cut-off date for mandatory removal of former Nazis from government positions. If a person could show they were not an active member of the party and joined only to save their jobs, they were not dismissed or denied employment. Challenges soon arose with the program, however. The question as to who was a Nazi was often a dark

89 JCS 1067 specified "All members of the Nazi Party who have been more than nominal participants, all active supporters of Nazism or militarism, and all other persons hostile to Allied purposes will be removed and excluded from public office and from positions of importance in quasi-public and private enterprise." Public office was interpreted as extending down to police chiefs and legal personnel; all persons appointed to these or higher offices after January 30, 1933 would be unemployable. The term "persons of importance in quasi-public and private enterprise" covered executives in civil, economic, and labor organizations; in corporations; industrial, agricultural, and financial institutions; in the press; and in education. 
riddle. Having been a party member did not prevent a man from being better at his job and having a more agreeable personality than someone who was not; in fact, the opposite was often true-a person individualistic enough to stand up to the Nazis was probably not going to fit in easily with the Americans, either. Military government officers generally agreed if they made a completely clean sweep of all Nazi party members, they were going to have to run the country with old men until the next generation grew up. A new cut-off date of May 1, 1937 was used for vetting purposes, because after this date all public employees were required to join the party or lose their jobs. By the end of March 1945, however, the press and public reaction resulted in a reversal back to the blanket prohibition on everyone who was or had been a party member at any time, or who had been appointed to an office of political importance since 1933. (Zeimke: 380-81)

Officially, whether someone was a Nazi was not a difficult question. SHAEF established automatic arrest categories ranging from the top Nazi leadership to the local levels. Thousands of suspects were arrested..$^{90}$ Most were not hard to find. The party kept excellent records, which often passed into military government hands intact. By September $1945,82,000$ suspected Nazis were being held in internment camps. (Id: 82)

Although denazification was one of the principal objectives of the early occupation period, its proposed scale quickly proved impractical. The occupying powers did not have the manpower or resources to accomplish such a thorough purging of German society, and the U.S. forces found it impossible to administer the state without interacting with and utilizing competent bureaucrats and officials, at least some of whom were complicit in the Nazi regime. (Peterson, 1977: Ch 4; Dept of State: 16-21) Numerous detachments quickly protested that, under the rules, they could not find enough people to begin reorganizing the German administration. On June 11, it was announced that post-1933 Nazis would again be acceptable. (Ziemke: 382)

90700 arrests per day in May and June of 1945; a total of more than 18,000 in August. 
Even in light of the updated standards, 100,000 persons were reported to be dismissed from public employment in the U.S. zone during the next three months and 20,000 were removed from private enterprise. On the whole, though, in July and August, denazification of public offices seemed to be going remarkably well, with approval even from the Germans. Then, on August 15, the U.S. broadened its definition to include people in any size of business or professional enterprise whose "standing was one of prominence or influence". When the new protocol met resistance from military government detachments, Eisenhower wrote to Patton, "I expect just as loyal service in execution of this and other policies applying to German occupation as I received during the war." On September 24, 1945, General Clay told the Control Council he was dissatisfied with the denazification progress. Two days later, Military Government Law No 8 was announced, prohibiting employment of Nazi party members in business in any capacity other than common laborer. The law applied not only to executives and managers, but also to private owners, including owner-operated bakeries, groceries, barber shops, and butchers. ${ }^{91}$ (Id: $\left.383-86\right)$

Rumors quickly began flying Rule No 8 was part of a plan to reduce the German economy to chaos. This was not far off the mark, since the rule potentially affected every person who was a party member and employed in a position requiring skills or responsibility ${ }^{92}$, and it effectively confiscated any Nazi-owned business. ${ }^{93}$ In October, General Clay further extended the law's common laborer provision to railway workers. (Until this time, the Services Forces had regarded railroad workers as having vital,

\footnotetext{
${ }^{91}$ Under the rule's guidelines, one detachment had to disqualify 20 medical doctors, 15 dentists, 51 teachers, 10 mail carriers, and 20 policemen. Another could politically clear only 3 of the town's 17 doctors, and still another was forced to remove a quarter of the area's 1,600 policemen.

${ }^{92}$ Owners were responsible for determining the status of their employees and workers. If a person wanted to appeal, they could do so later before boards of non-Nazi Germans.

${ }_{93}$ The detachments in one city took control of 93 Nazi-owned properties in November, 168 in December, and 919 in the first quarter of 1946. In Bavaria, military government took control of a record 1,912 properties in December. Another 1,777 Nazi-looted, mostly "Aryanized", properties were recovered from Germans who had acquired them before 1945 in forced sales.
} 
irreplaceable skills and argued successfully they were not public employees in the ordinary sense.)

Eventually, 20,000 railway workers were removed from their jobs. (Id: 389)

\section{Germany: Local Tribunals}

By December 1945, it was clear the status quo could not continue. As long as Rule No 8 was enforced by Americans, military government strength in the field would have to be maintained at levels not feasible and the entire occupation was fused for a political explosion. By the end of 1945, Clay said it was time for the German people to take charge of denazification. (Id: 429) Allied leaders realized the choice was either rebuild Germany using former Nazis or not rebuild it at all. Employing former Nazis was down-graded from 'under no circumstances' to 'as long as you were not an active Nazi'. People were permitted to submit a fragebogen, a written declaration of any Nazi ties, or lack thereof, for review by local boards. (Casella, 2003: 12-13)

From the beginning, the Germans approached denazification differently than the Americans. While the Allies only distinguished between active and nominal Nazis, the Germans recognized several levels of gradation, settling on five: major offenders, offenders, lesser offenders, followers, and exonerated, and adopted a scale of sanctions based on the offense ${ }^{94}$, thus allowing options to permanent exclusion. The Germans meant to remove the Nazi stigma from the individual and reinstate him to a position within society. When word of the new approach reached the press, the New York Times charged the officers responsible for denazification with losing sight of the reasons for which the war was fought. (Ziemke: 400)

Those with chargeable associations (eventually, the number reached 3.6 million) would appear before tribunals of local, non-Nazi citizens. After hearing evidence from both sides, the tribunal would

\footnotetext{
${ }^{94}$ Under the new German rules, major offenders would receive up to ten years in prison, offenders would serve five years or less, lesser offenders could be fined 10,000 marks, and followers up to 1,000 marks.
} 
place the defendants into one of the five categories and assess penalties accordingly. Since the boards were not required to establish adverse cases, most were content to hear only evidence produced by the defendant. In one town, 810 of 864 received lighter punishments; in another, only 2 of the first 80 defendants were imprisoned. Those who were exonerated or paid fines were considered de-Nazified and recovered full civil rights. (Id: 389,431 )

The German rules for denazification had their own obstacles. In most places, the military government detachments were not able to find enough men to staff the tribunals, and finding competent judges and prosecutors was impossible. No one, whether anti-Nazi or not, wanted to judge their friends and neighbors. Those who did would likely have trouble for the rest of their lives. In the end, more than 90,000 cases were heard and over 65,000 of them were decided in favor of the appellant. Approximately two out of every three defendants returned to their jobs and recovered their property. By June of 1946, $90 \%$ of the Germans initially purged were rehabilitated. As the standard of living rapidly improved throughout the sector, there was accelerated progress toward political goals. (Jennings: 15)

The implementation of war crimes tribunals and the complete purging of Nazis from public life was messy, controversial, and occasionally unfair; however, it consolidated the democratization process by removing a potential threat to democracy. It also eliminated virtually all support for the return of the Nazi regime and caused a thorough repudiation of Nazi policies throughout German society. Local detachments were not experiencing a decline in military court cases, but black marketeering, DP crimes, and fragebogen falsifications took the place of curfew and petty crimes cases. At the higher levels, ten Nazi leaders were sentenced to death by hanging, and all but three of the remaining 14 received lengthy prison sentences. (Dobbins: 13)

The most common complaint against the denazification program was it did not reach all individuals who had profited from the Nazi regime. (Ziemke: 279-80) In the long run, the more practical 
approach to denazification helped lead to a more thorough repudiation of Nazi policies by the German populace and eliminated remaining support for the return of such an autocratic regime. Those areas where denazification was the most thorough also seemed to have the strongest popular support for military government. (Dobbins: 14)

Japan: De-Militarization

In Japan, demobilization and disarmament of the seven million men in the Japanese armed forces was the first task of the occupation, along with successful reintegration of those men into society. MacArthur agreed to allow Japan's Army and Navy ministries to handle their own deactivation. The Imperial headquarters was quickly abolished, followed by the formal dissolution of the Combined Fleet and Navy General Headquarters and closure of the army headquarters. Complete demobilization was finalized by October 1945 and the service ministries were dismissed on December 1. By the end of 1945, Japan's armed forces ceased to exist. Paramilitary and ultranationalist organizations were also disbanded. Demilitarization was ultimately enshrined in Japan's new constitution. (Dobbins: 34) Vetting members of Japanese institutions was initially more challenging than in Germany since there was no equivalent of the Nazi party to use as the litmus test of taint. In the beginning, the occupation government worked from lists of militarists and outspoken nationalists prepared from intelligence gathered before the war's end. These individuals were removed from their posts during the first weeks of the occupation. At the same time, propaganda, intelligence, military, and national organizations and associations were abolished. Americans-both military and civilians-assumed critical governing functions and oversaw the rank-and-file Japanese left in place. The role of the Japanese government throughout the occupation was nominal, but important. By themselves, the Japanese government and the bureaucracy were virtually powerless. (Jennings: 17-18) 
The militarists identified by the Allies before the surrender were purged within the first ten weeks, and occupation forces and local Japanese citizens identified and removed remaining militarists within eight months. (Jennings: 35) SCAP did not issue a formal purge order until January 4, 1946, targeting politicians, bureaucrats, police, and military officers. Much to the dismay of the Japanese who were told to implement it, the order was based on wartime positions, not actions. The order aimed at those in designated organizations, including wartime cabinet ministers and other high public officials; the Special High Police; governors of occupied territories; members of the ultra-right Military Virtue Society; and officials of the Imperial Rule Assistance Society, an umbrella organization created midway through the war to unite all political forces behind the emperor. All who held leadership positions within these organizations were removed and barred from participating in public life. In the end, more than one million citizens were screened and 210,000 were affected by the purge, but this was a much lower percentage than in Germany, where $2.5 \%$ of the population was affected. Over $80 \%$ of the Japanese affected were military officers, followed by politicians at 16.5\%. (Dobbins: 41; Schonberger, 1989: 61)

Japan: Economic Purge

After the political purge in Japan, SCAP turned its focus to economic leaders. Business leaders were removed, followed by relatives to the third degree in hopes this would break the traditional family system. An additional 3,488 citizens were screened, with 350 purged. As a final step, the program was extended to education and public information media, where 5,000 teachers were barred from the profession and 210 journalists were purged. (Bridoux, 2011: 132-33)

As in Germany, there was no modern legal precedent for MacArthur's reforms of Japanese society. The changes were made by fiat and decried within the first months of the occupation. Those who remained in government were stunned at the extent the occupation subverted common Japanese cultural understanding of class and propriety. Japanese officials, including new Prime Minister Yoshida 
Shigeru, despised the purge ${ }^{95}$ and warned MacArthur he was risking anarchy, chaos, and the rise of communism by extending the program to local and regional levels. (Dower, 1979: 332) The emperor encouraged cooperation and goodwill with occupation forces, but made few direct comments on the reforms. Even this minimal show of support, however, lent enormous legitimacy to the reform process for the general public. (Jennings: 16)

An important element of MacArthur's strategy was to work locally among outlying communities, completely bypassing the conservative top and middle layers of the Japanese government. For instance, local elections were held in which women were permitted to vote for the first time, and roving teams of civics instructors were dispatched to cities and towns to discuss the nature of democracy. Some of these teams were followed by civil affairs officers, who then organized communities to begin reconstruction projects. It was democracy in miniature and it helped communities address their real needs while developing an appreciation for political participation that proved useful after the return of sovereignty. As democratic government emerged in Japan, programs such as these encouraged a critical mass of citizens to take part in elections and to engage in political discourse while making demands and articulating interests to their new government. (Jennings: 28)

As in Germany, Allied intentions to purge more deeply into Japanese society were trimmed. ${ }^{96}$ Japan's purge was thought to be preventative as well as punitive, so the Japanese would not return to a militarist stance. Over time, however, the purge lost its impetus for the moral imperative of eradicating the former elites from positions of power. The U.S. turned to a more pragmatic downsizing of the scope of the purge known as the Reverse Course, intending to maintain the institutional structure and competencies needed for reconstruction to progress. Benefiting from a secure and stable environment,

\footnotetext{
95 Ironically, Shigeru only became Prime Minister because of the purge. Following the general election of 1946, Ichiro Hatoyama of the newly-formed Liberal Party was elected Prime Minister, but he was soon purged by the Allies.

${ }^{96}$ Because of the existence of the Nazi party, occupation forces in Germany focused more heavily on civilian officials and politicians, versus Japan, where society was largely militarized.
} 
occupation policies were eventually welcomed by the population, particularly as they were seen to punish those responsible for the war. By rallying the Japanese around the re-invented emperor as a leader of the new, democratic, and peaceful nation that could quickly become a "western" leader in the region, the U.S. seeded consent for the democratic process, even while risking the country's deprivation of required technical skills for running the economy. (Bridoux: 133, 175) Thus, while the purge was an expression of coercive power by SCAP, the preservation of imperial institutions and the decision to work through the Japanese government contributed to the acceptance of the Japanese political elite and the general population to the reshaping of their society and its government. A December 1945 survey showed $70 \%$ of the Japanese were satisfied with the occupation's policies. (Id: 134, 170; U.S. Strategic Bombing Survey, 1947)

Iraq: Pre-Invasion Recommendations

In 2002, two dozen military experts gathered at the Army War College to discuss post-armed conflict concerns should Saddam be overthrown. Their report specifically recommended against the two major steps Ambassador Bremer would pursue in 2003 after being named the leader of the U.S. occupation. They advised the Iraqi Army be kept intact, since it could serve as a unifying force in a country that could fall apart under foreign control ${ }^{97}$, and were likewise explicit in warning against the top-down style of de-Baathification Bremer would mandate. (Ricks: 73) These were not the only experts to give such cautionary warnings. A 2003 RAND report advised that removing senior Baathists and serious human rights violators from the officer corps of the Republican Guard and Iraqi Armed Forces, security forces, and police forces and the demobilization of personnel should be systematic and

\footnotetext{
${ }^{97}$ The report stated, "In a highly diverse and fragmented society like Iraq, the military is one of the few national institutions that stresses national unity as an important principle. To tear apart the army in the war's aftermath could lead to the destruction of one of the only forces for unity within the society."
} 
politically sensitive. RAND indicated these individuals were unlikely to have realistic political objectives and would probably turn to "expressive violence" if alienated or offended. (Dobbins, et al: 172)

In November 2002, the State Department's "Transition to Democracy in Iraq" report recognized a huge political and security vacuum would open up with the fall of Saddam's regime and this vacuum would need to be filled immediately. The report also emphasized the urgent need to legitimize governance from the ground up, and suggested local elections (with internal support, training, and monitoring) be held throughout Iraq within a year of Saddam' fall. (Diamond, 2005: 28) Finally, the United States Institute for Peace (for which Under-Secretary of Defense and key occupation strategist Douglas Feith was a board member) issued an article in April 2003 stressing treatment of the Iraqi Army would be important, since it was "perhaps the single most potent and legitimate symbol of statehood in the country and should not be humiliated." The Institute recommended confining the army to their barracks for a brief period to vet and purge objectionable individuals, and then giving soldiers incremental responsibility to assist with constabulary duties (Jennings: 35), as was done in Germany.

Iraq: De-Baathification

Ambassador Bremer was, in many ways, a logical and impressive choice to take command of the American occupation. A tough-minded, politically conservative, widely experienced diplomat, Bremer was one of the fastest-rising stars in the State Department during the 1970s and 1980s. A skillful, takecharge leader, he would quickly come to be seen in Baghdad as a man in control, but he disavowed any comparisons to MacArthur. (Diamond: 36-37)

Prior to Bremer's appointment, in March 2003, Secretary Rumsfeld asked ORHA head Jay Garner what his plans were regarding de-Baathification. Garner saw two possibilities: either the locals would kill the most offensive Baathists or the locals would identify them over time. As a result, Garner planned to remove just two people in each ministry and major government office-the top Baathist and the chief 
personnel officer. Rumsfeld responded this approach would be acceptable until a more formal policy was developed..$^{98}$ One of the first things Bremer did after arriving in Iraq was show Garner the order he intended to issue to rid Iraq of Baathist leadership. In addition, anyone holding a position in the top three management layers of any ministry, government-run corporation, university, or hospital who was also a party member would be deemed a senior Baathist and fired, as well as prohibited from any future government service. (Ricks: 105, 158-59; Diamond: 39)

Bremer's first order as CPA administrator, known as CPA Order \#1, was issued on May 16, 2003. It disestablished the Iraqi Baath Party and officially began the process of de-Baathification. Bremer believed such an order was critical in eliminating the foundation of the previous regime and demonstrating to the Iraqi people neither Saddam nor his "gang" were coming back. (Bremer, 2006: 57) Bremer compared the order with de-Nazification and with the prohibition of militarism in Japan. He also complained there was no Iraqi who could deal with the economic problems in the country. (Maulucci, 2008: 122) In addition, Bremer later clarified his order to include "any person holding the rank under the former regime of Col or above, or its equivalent, will be deemed a Senior Party Member" and so would not be eligible for any pension payments. This cut off tens of thousands of influential Iraqis, some of the wrongly, because it mistakenly assumed one could not be a senior official without being a party member. Only later did the CPA learn even some top Iraqi generals were not in the party. (Id: 162-63) It is estimated in the highest grades alone, 30,000 to 50,000 individuals were purged by de-Baathification, though the real number was likely much higher. ${ }^{99}$ (Diamond: 39 )

The CIA station chief urged Bremer to reconsider. "These are the people who know where the levels of the infrastructure are, from electricity to water to transportation. Take them out of the

\footnotetext{
${ }^{98}$ This fact seems to, again, highlight the misunderstanding between the two men of Garner's role. Rumsfeld foresaw a more formal policy being developed over time and Garner thought his work would be finished in two weeks.

${ }^{99}$ Some estimates place the number as high as 85,000 . (Ricks: 160 )
} 
equation, and you undercut the operation of this country." David Nummy, an expert on the financials of transitioning and developing countries, called on his knowledge of Ukraine, Bosnia, and Kosovo to argue "Iraq was not the first totalitarian system we had engaged with, not the first one-party state we had worked with, and that there was absolutely no experience in any country that said being a member of the dominant political party meant you were a bad guy." The deep cuts made for an abrupt change from the more gradual process begun by Garner and his staff. In addition, those removed were almost all Sunnis, impeding Bremer's intention to achieve sectarian diversity in the new Iraqi leadership. Sunnis had long constituted the ruling class in Iraq, yet they now found themselves ostracized from the political landscape. (Ricks: 159-60)

One observer noted Bremer made decisions with a high level of confidence, but little knowledge of the country:

“He didn't know what he was doing. When Chalabi ${ }^{100}$ came in and said the Baath party was horrible, it should cease to exist, that sounded reasonable. But if you take the time to analyze the situation, you realize that the Baath Party was the state ${ }^{101}$, and when you dissolve the party, you dissolve the state. You then deprive yourself of the whole state. You deprive kids of teachers, people of doctors. You deprive the country of engineers who could fix the infrastructure."

(Id: 294-95)

A competitor to the Chalabi way of thinking was Zalmay Khalilzad, an Afghan who had been involved in Middle East and Asia policy since 1980. At the time of Iraq's occupation, he was the highestranking Muslim American in the Bush administration. Khalilzad was a senior State Department official under President Regan, advising on both the Soviet incursion into Afghanistan and the Iran-Iraq War. During H.W. Bush's presidency, he served as Deputy Under-Secretary of Defense for Policy Planning.

\footnotetext{
${ }^{100}$ By 2008, Chalabi was under investigation for fraud and had yet to win an elected seat in Iraq.

${ }^{101}$ As membership in the party became a touchstone of loyalty in the 1980s, it also became a channel of mobility. Party membership became essential for employment, acceptance to elite schools, and professional advancement. (Marr, 2012: 207). Based on the author's personal experience, this extended to all levels. One of the Iraqi court employees she worked with in Baghdad talked about how his son was not allowed to play on school sports teams if his father was not a Baathist.
} 
From 1993 to 2000, Khalilzad worked at RAND as Director of Strategy, Doctrine, and Force Structure. He was asked to lead the Bush-Cheney transition team for the DoD in 2001, and named Special Assistant to the President for Southwest Asia on the National Security Council. In December 2002, he was appointed by President Bush to work with "free Iraqis" to coordinate preparations for a post-Saddam Hussein Iraq ${ }^{102}$ and was chosen by President Bush and Secretary of State Colin Powell to assist Bremer in the formation of the new Iraqi government. Upon his arrival in Iraq, Khalilzad conducted several meetings with Iraqi leaders on the political arrangements for a new government. He favored a more tempered approach to heal the nation and-most importantly-he had nothing to gain. But Chalabi and Bremerfearing unity of command issues and a difference of opinion-secured Khalilzad's removal from the team, shocking both Powell and National Security Advisor Condoleezza Rice. ${ }^{103}$ (Wieler, 2009: 22; Gordon and Trainor: 476)

Special Forces (SF) units tended to take a gentler approach to de-Baathification in their areas of operation. SF soldiers knew a functioning city administered in part by some former Baathists was better than a desolate one stripped of them. One unit developed a renunciation program in which people who were becoming part of the interim government repudiated the party and pledged to serve and protect the people of the new Iraq. (Ricks: 153) Despite the challenges, de-Baathification was popular with most of the population, especially among the Shia and Kurds. It rapidly became a key political issue in the new Iraq and a sharp point of disagreement between the new-mainly exile-opposition leaders and a minority who had been affiliated with and benefited from the previous regime. U.S. administrators would soon backtrack on de-Baathification, though, recognizing-as they had in both Germany and

\footnotetext{
102 Khalilzad would later become the U.S. Ambassador to Iraq in 2005.

${ }^{103}$ Bremer's book, My Year in Iraq, devotes no more than five lines to Khalilzad, with the content scattered over 75 pages. He is caustically referred to as "then-presidential envoy", with Bremer expressing frustration Khalilzad had already met with key Iraqi leaders by the time Bremer arrived in Iraq, even though the Afghan was operating under presidential orders at the time. In November 2003, Khalilzad was named Ambassador to Afghanistan and oversaw the drafting of its new constitution.
} 
Japan 60 years before - the need for trained, local personnel. Again (as in Germany and Japan) they sought "reconciliation" and a middle ground, but not before the issue had become intensely polarizing.

(Marr: 267)

Iraq: Disbanding the Military

Next came the dissolution of the Iraqi Army and National Police Force. This decision was another significant departure from what Garner discussed with Rumsfeld and others before leaving Washington for Iraq: "One of our goals is to take a good portion of the Iraqi army and put them to work in reconstruction. The regular army has the skill sets to match the work that needs to be done." On February 19, 2003, Garner briefed Rice on his plans and a few days later he briefed Rumsfeld. The briefing slide for the Iraqi Army stated it would be "necessary to keep the Iraqi Army intact for a specified period of time. It serves as a ready resource pool for labor-intensive civil works projects."

(Ricks: 103, 161)

War planners at CENTCOM working on OPLAN 1003V, Operation: IRAQI FREEDOM, finalized the plan for the post-conflict phase, assigning the Combined Force Land Component Commander (CFLCC) the primary responsibility for post-conflict operations. The plan assumed the use of the Iraqi army to assist in reconstruction. Iraqi Soldiers were to go through a formal draw-down process, be paid, and assigned tasks to assist with occupation efforts. Initially, it was estimated 40,000 were needed, with more added as required and as U.S. troops returned home. The Iraqi soldiers not immediately employed were to be paid to maintain their recall information and be at a ready status. ${ }^{104}$ (Bensahel, et al: 142) Before the war began, Garner and the military laid out several plans for what to do with Iraqi security forces. Recognizing the danger posed by complete demobilization in an environment of high

\footnotetext{
${ }^{104}$ This plan might not have been seen as ideal by the Iraqi populace either, and would likely have been heavily criticized, but it would have allowed for the Iraqi army to be recalled and stood up much faster than the course of action ultimately chosen.
} 
unemployment, the plan called for the dissolution of the Iraqi Republican Guard, the engagement of soldiers from the regular army in reconstruction efforts, and the foundation of a new army using three to five existing Iraqi divisions. These plans were presented to President Bush by Under-Secretary Feith during a National Security Council meeting on May 12, 2003. (Gordon, 2008)

Upon his arrival in Baghdad ${ }^{105}$, Bremer and his senior advisor, Walter Slocombe, came to favor the complete dissolution of the army. This view was based on the belief the Iraqi army had already demobilized itself and could not be practically reconstituted because the Iraqi conscripts would not return to duty and the Iraqi military facilities were destroyed in the campaign. (Fallows, 2005) According to Bremer, he sent a proposal for disbandment to Rumsfeld on May 19, 2003, along with the recommendation all former troops—save some top intelligence, security, and Baathist leadership — be given severance payments. Feith requested some editing of the text on May 22, and that night Rumsfeld's Chief of Staff and a CPA spokesperson coordinated plans for the actual announcement. After allegedly receiving permission from Rumsfeld, Bremer briefed President Bush by video conference and subsequently signed the order on May 23. (Bremer, 2006: 57) CPA Order Number 2: Dissolution of Entities disbanded the Iraqi military, security, and intelligence infrastructure. The list of government entities dissolved under the order was extensive. ${ }^{106}$

\footnotetext{
${ }^{105}$ When Bremer arrived in Baghdad, he carried with him the after-action report of lessons learned from the occupation of Germany. (Bremer: 38)

106 The entities were:

Ministry of Defense

Ministry of Information

Ministry of State for Military Affairs

Iraqi Intelligence Service

National Security Bureau

Directorate of General Security

Special Security Organization

Iraqi Army, Air Force, Navy, Air Defense Force, and other regular military services

Iraqi Republican Guard

Directorate of Military Intelligence

Emergency Forces

Baath Party Militia

The National Assembly
} 
A different series of events was portrayed by Bob Woodward in his book, State of Denial.

According to him, the decision to disband the military never came back to Washington for input, except for a lawyer from the National Security Council who gave a cursory review. Rumsfeld said he rarely spoke with Bremer about it, no NSC meeting was ever convened on the matter, and he would be "surprised" if Deputy Secretary Wolfowitz or Under-Secretary Feith told Bremer to carry out the order. ${ }^{107}$ (Woodward, 2007: 197-98) Secretary of State Colin Powell also said he was never consulted on the matter, which he believed to be a major mistake, and Condoleezza Rice was said to be "surprised" by the decision. Feith subsequently stated it was Bremer's idea to disband the army, but Bremer denied this and said he could not remember who first came up with the plan. (Gordon) In a later interview, President Bush stated the initial plan was to maintain the Iraqi army and he was not sure why that did not occur. (Andrews, 2007)

In response to Bush's report, Bremer provided the New York Times with a letter sent by him, through Rumsfeld, to the President on May 22, 2003 explaining the order for disbanding the military, for which Bremer claimed the President sent a thank-you note ${ }^{108}$. Furthermore, Bremer stated he sent a draft of the order to Rumsfeld, Wolfowitz, Feith, the Joint Chiefs of Staff, and the Combined Forces Commander on May 9, before he even left for Iraq, though with certainty the Secretary of State, NSA, CENTCOM, and the CFLCC say they were not consulted. (Gordon and Trainor: 483) The Times quoted an

Murafaqin and Himaya (Hussein bodyguards)

Friends of Saddam

Saddam's Lion Cubs

Presidential Secretariat

Revolutionary Command Council

The National Assembly

The Youth Organization

National Olympic Committee

Revolutionary, Special, and National Security Courts

${ }^{107}$ It appears both Doug Feith and Paul Wolfowitz knew of, contributed to, and cleared the decision, though various reports conflict on the clarity Rumsfeld had on the matter.

108 This note did not include clear approval for CPA Order \#2, but rather said Bremer had the President's "full support" for all he was doing in Iraq. 
anonymous White House official that the original plan to maintain the army could not be carried out and the President understood. Chairman of the Joint Chiefs, General Peter Pace, later stated the Chiefs of Staff were not consulted for advice or recommendation in regards to the order. (Andrews, 2007) In fact, not one military commander can be confirmed as having been consulted about the order, and severalincluding General Petraeus-protested the order twice without success (Gordon and Trainor: 414, $488)^{109}$

Regardless of which sequence of events is correct, the confusion and miscommunication-if not outright deception - regarding who knew what and when in relation to the most controversial and farreaching order of the occupation is telling as to how the senior leadership was operating in Iraq. Several British generals later said they raised concern about the disbandment and were personally against it, though Bremer responded no UK officials voiced concerns in their meetings and they regarded the effective demobilization of the Iraqi army as a "fait accompli". These claims were disputed by senior British officers. (Norton-Taylor, 2004)

As Bremer states in his book, My Year in Iraq, he felt he had little choice in the matter of the military - the Iraqi army disbanded itself. The arguments for the order were mostly ethnic-based and symbolic, but also punitive and financial, and the alternative-recall the army and conduct a classic demobilization , disarmament, and reintegration process-could have proved too difficult. Reinforcing this argument is the fact the military infrastructure, base headquarters, and barracks were abandoned, damaged by coalition forces, and then destroyed by looters. It was Bremer's assertion most of the Iraqi army was conscripted and displeased with their standing in the defense forces. He felt most soldiers would be content remaining at home, as the coalition requested through leaflets prior to the

\footnotetext{
${ }^{109}$ Those who drafted the order-Bremer, Feith, Slocomb, and Wolfowitz-have zero collective military experience. Additionally, Slocomb, the CPA's Military and Security Advisor, had not spent one day in Iraq prior to reviewing the order.
} 
offensive ${ }^{110}$ Additionally, the CPA assessed Shia soldiers would not respond to a recall, believing the Shia would see the invasion turmoil as an opportunity to be free of corrupt and abusive Sunni officers. Soldiers who watched their leaders flee to escape persecution for Baath party affiliation possessed little incentive to remain at their damaged barracks and went home, taking their weapons and equipment with them. (Fallows, 2004) By the CPA's estimate, recalling the Iraqi military and finding appropriate work space and shelter was too daunting a task. ${ }^{111}$

Obviously, the security apparatuses most closely tied and loyal to Saddam Hussein should have been disbanded; however, before the war, most experts recommended against eliminating the conventional army since this would not be in the best interest of the coalition or the country due to practicality, symbolism, nationalism, economics, and mass disenfranchisement. (Fallows) The numbers alone demonstrated the coalition could not afford to disband the Iraqi military: they were a needed asset to the coalition in order to preserve security in areas the CPA and U.S. military could not reach. (Weiler: 6-8) The CPA rightfully wanted to create a new army loyal to the principles of a new representative government. Clearly, this meant a mid- to long-term sacrifice in an indigenous security force. A memo signed by Secretary Rumsfeld, titled "Principles for Iraq: Policy Guidelines", stated the coalition would "actively oppose Saddam Hussein's old enforcers - the Baath Party, Fedayeen Saddam, the Special Republican Guard, etc-and it will make it clear the coalition will eliminate remnants of Saddam's regime." This, coupled with the Department of State's Future of Iraq project message, "the Iraqi Army of the future cannot be an extension of the present army, which has been made into a dictatorship", provided Paul Bremer with the ammunition and justification he needed to formally dissolve the military. The message was clear: the Iraqi military was seen as too partial, too

\footnotetext{
${ }^{110}$ A part of the coalition's information operations campaign was to convey to Iraqi soldiers they would be rewarded after the war if they did not resist the coalition.

${ }^{111}$ It should be noted, however, that the U.S. was quickly able to repurpose government buildings and Saddam's numerous residences around the country to house CPA personnel, U.S. military forces, and later for use as detention facilities.
} 
contaminated, and too infiltrated with Baathists to be salvaged. (Id: 5) Lastly, the CPA thought it inconceivable and unjust to support and, more importantly, pay over 400,000 soldiers of the Iraqi Army (Gordon and Trainor: 482). The very institution that protected Saddam Hussein and projected fear in the hearts of its populace should not be compensated: "We don't pay the armies we defeat," asserted Slocombe. (Fallows: 6)

The argument against disbanding the Iraqi military stems from a more practical vision of how to execute a reconstruction and healing era. Every major prewar focus and study group concluded that retaining a foundation of the Iraqi army outweighed a complete dissolution. These groups consisted of the Iraqi Relief and Reconstruction Group, sponsored by the National Security Council; Task Force IV, led by CENTCOM; the Office of Special Plans in Rumsfeld's office; the Department of State's Future of Iraq project; the Center for Strategic and International Studies; ORHA; and the Army War College's Reconstructing Iraq scenario. (Weiler: 6) The most obvious argument against dissolving the Iraqi military was the unemployment of 400,000 Iraqi service members. It was clear to most research organizations what would happen in a highly militarized society once the regime fell if the army was not employed. The Combat Studies Institute provided accurate insight in its publication, "Warfare in the Age of NonState Actors: Implications for the U.S. Army":

"The demobilization of a foreign army-an army primarily of men, whose means of employment was to be trained to use weapons and explosives in a skilled manner to kill-is perhaps the greatest and most critical task in a post-conflict environment. Taking away the jobs and weapons in which so many men have depended for so long, and giving them an equivalent occupation in peacetime (something even highly educated U.S. military personnel find challenging), is a delicate and absolutely vital challenge that has little room for error. To simply disband them is extremely dangerous."

Jean-Paul Sartre, a former member of the French Resistance during World War II, once commented, "Violence suits those who have nothing to lose." Putting people well-trained to kill on the streets with no jobs or compensation certainly risks giving them "nothing to lose" and the potential for waves of violent crimes and insurgency becomes very real. Even the Iraqi manual on Guerilla Warfare 
taught the best place to recruit for an insurgent force is from a defeated army. (Gott and Brooke: 116; Weiler: 10)

A number of American generals worried specifically about the flood of unemployment and frustration resulting from the dissolution of the army. As one U.S. official later commented, "That was the week we made 450,000 enemies on the ground in Iraq." (And over a million more, if one counted their dependents.) In the ensuing months, violence increased significantly and grew-as experts had predicted it would-into a well-organized and well-financed insurgency. The generals who opposed the decision knew it would create a security vacuum, humiliate a strategic, well-armed sector of society, and stimulate a violent backlash. But Bremer was convinced demobilization was the right course. (Diamond: $39,294)$

Ultimately even more disruptive than de-Baathification, the sudden end of the Iraqi Army came as a shock to much of the population. Former soldiers not only lost their jobs, but also their pensions. (Marr: 268) As late as May 15, 2003, the CPA website stated 30,000 former members of the Iraqi army had registered for emergency payments, of which 9,000 were soldiers and enlisted men. The website said the CPA's goal was to bring them back to active duty, so when CPA Order \#2 was issued on May 23, it abruptly terminated the livelihood of hundreds of thousands of men and created a vast pool of humiliated, antagonized, and politicized individuals, many of whom were armed. (Ricks: 162, citing Faleh Jabar, an expert on the Baathist Party and Senior Fellow, U.S. Institute of Peace) Former Iraqi military leaders who had been working with the ORHA to recall the army and go through a reintegration process were confused when the new CPA announced the elimination of the army. At the end of May and early June 2003, dismissed ministry workers and former Iraqi soldiers held a series of demonstrations, with some vowing they would violently oppose U.S. decisions. On June 18 , an estimated 2,000 Iraqi soldiers gathered outside the Green Zone to denounce the dissolution decision. Some carried signs reading, "PLEASE KEEP YOUR PROMISES". Others threw rocks. (Ricks: 164) 
Iraq: Resulting Lack of Unity

The symbolism of dissolving the defense forces of Iraq was the most unexplored element of the debate. The opponents to retaining the Iraqi military were quick to demonstrate the symbolism and the message sent by keeping the old regime's tool of oppression, but did not examine the converse symbolism of diminishing the nation's shield. The Iraqi military was viewed as the "anchor" of the country, one that had stayed intact through the British occupation, a brutal Iran-Iraq war, and numerous coups. In Iraq's history, previous uprisings would result in a purging of the military's strategic level components, but the army remained as an institution of defense. Although it was a force controlled by top-level Baathists, at its grass roots it was not genuinely loyal to Saddam. (Al-Marashi, 2007: 42-53) Although the army was dominated by Sunnis, aside from top-tier Baathists, it was actually a diverse organization. There were distinguished members of the Iraqi military representing all parts of the nation's ethnicity: Kurdish officers, Christian Special Forces, and Shia generals. As with government employees, many members of the army were Baathists in name only. Realists understood the path to economic survival and employment was to be a Baathist, regardless of tribe or religious sect. (Weiler: 9)

The army was, in fact, the last symbol of sovereignty to a war-torn nation needing liberation from a brutal dictator. Invaded by a non-Muslim force, but also liberated, many Iraqis were willing to welcome the coalition with warm hearts, but they were not willing to be completely disassembled by a nation that did not even understand the politics of survival in their country. Disbanding the military was seen as an attack on Iraqi identity and sovereignty. (Weiler: 16) Depending on the accurate populace perception of Iraq's army, stripping the nation of its military may very well have turned the liberation force into a perceived oppressive occupation (Al-Marashi: 47).

Like de-Baathification, the demobilization order was driven by the hope of restructuring Iraq from the ground up. The refusal to reconstitute and use Iraq's regular army contributed more than anything else to the rapidly deteriorating security situation in the country. The United States not only 
lost control of Iraq's borders, but also most of its local population centers, while alienating the largest and most lethal portion of the population. The army was a proud organization: the shield of Iraq, and the largest and most effective army in the Arab region, until it was ordered to disintegrate without being told about future opportunities. In a nation where honor is a measure similar to wealth, a powder keg was about to ignite. The lack of security forces and lawlessness left sects and tribes competing for postregime power. (Id)

The insurgency began to mature after the dissolution of the army. Sunni officers and cadres were left without a job and deprived of termination payments. They turned their skills and knowledge to the service of the insurgency. Various Shia militia saw their ranks swollen by the rank and file of Saddam's army, hundreds of thousands of young men left idle and bitter. (Bridoux: 99-100) Former Iraqi Defense Minsiter Hazim al-Sha'lam declared following the dissolution, the problems of "anarchy" and "lawless behavior" were exacerbated: "Through this lawlessness, certain groups built dens of deceit, crime, and corruption. Had the Iraqi army remained, these things would not have happened." A former army officer who joined the insurgency stated he did so because of the "shame and humiliation" at the dissolution of the army. (Weiler: 16)

In May 2003, following de-Baathification and the dissolution of entities, the casualties quadrupled from the March/April offensive combat levels, and then increased $750 \%$ by the end of the summer. The casualties subsided in the less-active winter months, from October 2003 to late February 2004, when the fully-matured insurgency emerged and the casualties went from 150 in March 2004 to 1,214 in May. The CPA's response involved major combat operations in the Sunni triangle and the Shiadominated south. Consequently, the public sentiment about the occupation worsened, which played in the insurgents' favor while contributing to further degradation of security. (Bridoux: 99-100)

Recruitment for the new army, minus its old officer corps, began in August, as did an attempt to rebuild the police. (Marr: 268) When the Iraqi Army was eventually reconstituted, it was done on the 
cheap. One U.S. Army officer said "We had to fight Bremer tooth and nail for a paltry increase in the salaries of the Iraqi military and police-and they still aren't being paid enough." (Diamond: 294) By the end of the CPA's tenure, Iraq's army numbered 180,000 troops, but the coming insurgency quickly demonstrated rapid recruitment and an inexperienced force with competing loyalties to political groups could not produce a professional military. Much the same result occurred with the police. (Marr: 268)

The first two CPA orders caused a worsening of the security situation ${ }^{112}$ and led to complications regarding the implementation of reconstruction projects in all other dimensions, such as the infrastructure, economy, and civil society. The lack of contingencies for dealing with consequences of both orders led to a situation in which the CPA lost the initiative and became reactive rather than proactive. It slowed down reconstruction because resources were focused on the improvement of the security situation. (Bridoux: 99-100)

When Colonel John Agoglia, who was working as a military liaison to Bremer in May 2003, heard about CPA Orders \#1 and \#2 he replied, "You guys just blindsided CENTCOM." That was the day, he recalled, "we snatched defeat from the jaws of victory and created an insurgency." Together, Bremer's orders put more than half a million people out of work and alienated many more dependent on those lost incomes. Just as important, in a country riven by sectarian and ethnic fault lines and possessing few unifying national institutions, Bremer had done away with two of the most important ones. (Ricks: 163) It is impossible to know whether not disbanding the Iraqi military would have prevented an insurgency, but it is certainly hard to believe it would have made matters worse. Some things are known, however: a $60 \%$ unemployment rate, an essential services crisis, 450,000 disenfranchised individuals with access to

\footnotetext{
${ }^{112}$ It should be noted the estimated 400,000 Iraqi soldiers who were put out of work equaled the number of troops CENTCOM initially estimated would be needed to secure the country. Though the Iraqi military was definitely not as well-trained as the U.S. Army, they had kept the populace under control for decades, prevented several coups, and understood the culture in which they were operating, so it is likely-had they been corralled soon enoughthey could have effectively worked in conjunction with coalition forces.
} 
weapons and ammunition, and international terrorists infiltrating unsecured borders certainly created formidable obstacles to success.

\section{Summary}

As was introduced early in this document, the U.S.'s biggest mistakes in Iraq occurred during its first few weeks in the country, with the issuance of CPA Orders \#1 and \#2. Numerous comparisons were made to similar orders de-Nazifing Germany and de-militarizing Japan, but those arguments focused on the initial 1945 orders, not the later effects of them. Also, in Germany and Japan, culpable individuals were removed from power but many of the governmental structures stayed intact; in Iraq, deBaathification not only removed most of the qualified workers, but also left no structure to fill.

Former Nazis were permitted to continue working if they were not "active" Nazis and only joined the party after it became mandatory. No such objective test was applied in Iraq. When there definition of "active Nazi" was broadened, military government realized the rule could not be enforced as written or occupation force levels would have to remain high for a much-extended duration. Such a commitment was not feasible, so former Nazis started being punished based on their level of activity, with the process turned over to the Germans by the end of 1945 . They instituted a stacked punishment scheme, and individuals who served their punishment were considered "de-Nazified" and regained full civil rights. ${ }^{113}$ But steps to track down former Baath members - other than the highest levels of Saddam's hierarchy-never happened; relatively few Iraqis received justice for the atrocities of the regime. Instead, most of the occupations efforts were focused on battling new insurgent violence, rather than punishing Baathists for their decades of atrocities.

\footnotetext{
${ }^{113}$ This brand of restorative justice has been used numerous times since World World II, most notably in Cambodia and Rwanda. It is largely a non-Western concept, however, and there is no evidence the CPA ever considered its use in Iraq. It likely would have worked well, given Iraq's strong sense of tribal communities.
} 
Bremer asserted many times he had no choice regarding his initial orders: the Iraqi army disbanded itself by simply walking away, and its facilities were destroyed. It seems unlikely, though, the Iraqi army's infrastructure was in a worse condition than Germany's by the time the Allies reached Berlin. Initially, there were no efforts to communicate to the Iraqi army or other government officials their jobs would remain intact after the invasion - that, in fact, we wanted (and needed) them to remain at their posts. Additionally, no steps were taken to secure Iraqi troops or installations-they were allowed to walk away. Finally, when it came time to re-establish the army, it was determined locating former troops would be too difficult, so the CPA instead decided to build from the ground up. It is hard to imagine how such an endeavor could possibly have been easier than locating former soldiers, a task that would have been far simpler if occupation officials were actually living among the public.

In 1945, many soldiers might not have agreed with the orders they were given, but it was clear who gave them. In Iraq, no one can agree on who actually decided to issue the most controversial order of the war: who came up with the idea to disband the military? The lesson to be learned is that, in a military conflict, leadership by committee does not work. And, again, U.S. officials looked to the start of the 1945 occupations to guide their decisions, rather than examining the results of those early decisions and adapting accordingly.

\section{Elections \& Drafting a Constitution}

Of the four Instigated Factors introduced and asserted in this work as being the most impactful decisions during an occupation, none has received less attention than the timing of democratic elections and the process through which a new constitution is drafted and ratified. This research attempts to fill this gap by presenting three different approaches to each process, and-clearly-whether they succeeded or failed at producing a democratic transition. 


\section{Germany: Elections}

In regards to democratic elections for Germany and Japan, the Potsdam Conference called for the establishment of local self-government "on democratic principles and, in particular, through elective councils as rapidly as possible and as is consistent with military security and the purpose of military occupation", with later extensions of authority to regional and state administrations. (Dobbins: 14) In Germany, a network of nominated local councils and a central advisory council were established as precursors to self-government (Barnett: 4). In early May 1945, the army brought in detachments to organize German provincial and district governments. Finding men with no Nazi involvement for the higher posts was arduous business. Many appointees had not worked under the Nazis at all due to age or political affiliation; if they had, they held much lower ranks. Some were women, for whom the Nazi discrimination against their sex proved to be an advantage during the occupation. (Ziemke: 272)

In addition to weeding out the Nazis, recruiters had to be careful to steer clear of overinvolvement with other political factions. Eisenhower reminded army commanders the purpose of military government authorities was not to actually govern, but to oversee the German governmental authorities - a fine and delicate line. (Id) Elections for small communities of less than 20,000 people were scheduled for January 1946, with elections for larger communities to be held a few months later. The hope was active political life would reconvene by the end of the year. (Dobbins: 15-16)

When SHAEF began to look into German political activity in June 1945, it could not find any in the traditional sense of the term. The vast majority of Germans were occupied with other things, such as food, housing, and other problems of survival. The twelve Nazi years left little with which to renew political activity - no other party had existed legally (or even illegally in any organized fashion) since 1933. In August, military districts were permitted to start licensing parties at the local level, but there was little to no interest from the public. The detachments quickly realized German politics involved much more than parties and rivalries: German appointees represented social, economic, and religious 
outlooks in addition to political ones. Special interests, such as the Church or individual cliques, were determining policy direction. The first parties on the scene were the Communists and the Social Democrats, neither of which bore the Nazi taint, but both were opposed by the Catholic Church and lacked a working class majority. The two strongest pre-Nazi parties showing signs of life were the Center Party and the Bavarian People's Party, and the U.S. was relatively generous in appointing their members to administrative posts. Both parties let it be known - to the annoyance of U.S. officials - they would welcome repentant Nazis to their ranks. (Ziemke: 361-63)

Throughout all the active parties, there was a concern about lack of experience and leadership. Except for a few survivors of the concentration camps, there was not an abundance of men with political backgrounds. Outside of the senior Allied staff, most military officers and German politicians wanted the elections postponed. There were reports the Germans were completely apathetic and ignorant towards the democratic process. None of the parties who received licenses wanted to risk their existence in a premature test of strength, and several of their members already had jobs as appointees. But General Clay believed in learning by doing, so the Germans were sent to the polls whether they were ready or not. Clay also realized that, with large numbers of officers returning to the U.S. in the coming months, there soon would not be sufficient manpower to run the country if they did not get Germans into the positions. (Id: 364-66)

Despite American misgivings and local disinterest, the Germans went to the polls for local elections in January 1946 in astonishingly large numbers: $86 \%$ of those eligible voted. ${ }^{114}$ OMGUS found this particularly gratifying, since it justified the assertion the new administration was based on popular support. But political principles were still obscure, since the successful parties welcomed former Nazis and either had strong ties to the Church or the Communist Party. One thing was clear: the average

\footnotetext{
${ }^{114}$ Before the elections, military government detachments reviewed the 4,750,000 names on the voting lists and disqualified 326,000.
} 
German still did not recognize the personal responsibilities accompanying political freedom. But the time for discussion was over: in April and May 1946, the Germans voted for regional councils, again with high turnouts. On June 14, 1946, OMGUS rescinded all existing military government denazification directives, officially ending military government in Germany. (Id: 427-28)

\section{Germany: A New Basic Law}

The Allied Governments had gradually relaxed their control over German political life. Control Council Law No. 4, enacted on October 30, 1945, re-established the German court system, based on legislation passed prior to Hitler's rise to power. Directive No. 16, passed on November 6, 1945, provided for the stand-up of the police forces with light weapons (and even carrying of automatic weapons with Allied permission) to combat crime. By March 1946, Law No. 21 provided for the establishment of labor courts run by German judges to resolve disputes within the population. (Allied Control Authority, 1945) However, a new German constitution would not be drafted until 1949, giving both the occupation and the population ample time to develop new economic, political, and social centers - in other words, to decide what they wanted their new country to be.

Though outside the general time frame of this research (approximately 12 months postoccupation-so, in Germany's case, April 1945 to May 1946), the process through which the Germans developed a new Basic Law should be noted. For ease of comparison, this discussion is placed in this section, rather than Chapter 6's five-year, post-conflict section.

In February 1948, the three western occupying powers of Germany (U.S., Britain, and France) began debating the political future of their respective zones. In June of that year, negotiations were concluded, leading to the establishment of a democratic and federal West German state. The presiding ministers of Germany's regional states were directed to arrange a constitutional assembly to draft a constitution for the new state. According to papers known as the Frankfurt Documents, the constitution 
was to specify a central government, while simultaneously respecting the various regional administrations, and would contain provisions and guarantees of individual freedoms and rights. (Kommers, 2012: 309)

The ministers were reluctant to begin this work, however, since they felt the creation of a West Germany state would mean a permanent separation from the eastern zone. On their accord, they decided to implement the requirements of the Frankfurt Document's on a provisional basis; therefore, they held a parliamentary council rather than a constitutional assembly, and the resulting document was referred to as a basic law, not a constitution. Thus, it was clear West Germany would not be the only state of German people; reunification and self-determination remained on the agenda. The Western Allied powers acquiesced to this approach. (Id)

Delegates to the parliamentary council were appointed by the leaders of West Germany's regional states. A preliminary draft was prepared in August 1948, and final editing started on September 1. At this time, a larger, 65-member parliamentary council was formed, with member being elected by the regional parliaments of their respective states. The final draft of the Basic Law was passed by the Council on May 8, 1949 and approved by the Western Allied powers a mere four days later. The ratification process was quick, and on May 23, 1949, the German Basic Law was signed and promulgated. The Federal Republic of Germany was now a fully-sovereign state. (Colling, 2015: 287)

Japan

In Japan, the Americans drafted and the Japanese translated, debated, tinkered with, and adopted a new national charter that remains one of the most progressive constitutions in the world (Dower, 2003: 4). The wording of the Potsdam Declaration and the initial post-surrender measures indicated neither MacArthur nor his superiors intended to impose a new political system on Japan unilaterally; rather, they hoped to encourage Japan's new leaders to initiate democratic reforms on their 
own. But by early 1946, MacArthur's staff and Japanese officials were at odds over the most

fundamental issue: the writing of a new constitution. The Japanese were extremely reluctant to replace the Meiji Constitution, while the Americans desired a far more liberal document. (Dower: 374, 375, 383, 384)

A committee of Japanese constitutional scholars began meeting in late 1945, but their recommendations were too conservative for U.S. officials and were rejected outright. On February 3, 1946, MacArthur directed the SCAP government section to draft a constitution to guide the Japanese cabinet in its efforts. He urged extreme haste and secrecy because he wanted to go public with a Japanese-endorsed draft before the newly established Far East Commission, an international advisory board that had been given jurisdiction over constitutional matters, convened in late February. SCAP completed the entire document in two weeks and presented a draft to Japanese officials on February 19. 1946. (Dobbins, et al, 2003: 43) Much of the drafting was by two senior army officers with law degrees, although other MacArthur appointees had significant influence, especially in regards to women's rights (Dower: 411). Although the document's drafters were not Japanese, the Meiji Constitutio, demands of Japanese lawyers, opinions of pacifist political leaders, and the earlier Japanese drafts were all taken into account.

An outline of the document was presented to the Japanese public on March 6, 1946. Elections for the House of Representatives occurred on April $10^{115}$, with the resulting body responsible for approving the constitution. The MacArthur draft, which proposed a unicameral legislature, was changed to allow a bicameral one, with both houses being elected. In most other respects, the new government adopted the U.S. version in its entirety, included the symbolic nature of the emperor, guarantees of civil and human rights, and renunciation of war. (Id: 407)

\footnotetext{
115 Under the new election laws, this was the first general election in Japan in which women were permitted to vote.
} 
Japan had an essentially homogenous population that rallied behind a common national causebuilding a new, democratic government. The population eventually accepted this hastily written and poorly translated document, as did the Far East Commission after suggesting minor revisions. The Constitution's SCAP origins were deliberately kept quiet, but the awkward phrasing of the document made the secret hard to maintain. Revision became a topic of fierce debate almost immediately, but many embraced this constitution despite its foreign origins, and-most remarkably-the document has never been amended. (Dobbins, et al: 44; Dower: 4)

The new constitution would not have been written the way it was had MacArthur and his staff allowed Japanese politicians and constitutional experts to resolve the issue as they wished. In late 1945 and 1946, there was much public discussion on constitutional reform, and the MacArthur draft was apparently greatly influenced by the ideas of certain Japanese liberals. But it did not attempt to impose a United States-style presidential or federal system; instead, the proposed constitution conformed to the British model of parliamentary government. (Moore, 2004)

\section{Iraq: Elections}

When Jay Garner was appointed head of the ORHA, he operated with the assumption an interim Iraqi government consisting mainly of the exiled opposition leaders, plus some additional Iraqis from inside the country, would form a transitional administration, help write a constitution, and then hand off to an elected body. None of these assumptions would prove correct. When Bremer took over in May 2003, he announced the U.S would seek a UN resolution ${ }^{116}$ confirming its status as an occupying power. He knew real change would require a longer period of transition and direct governance by the United States before control was handed over to an Iraqi government. On May 16, Bremer met with the exiles

\footnotetext{
${ }^{116}$ This was accomplished with UN Resolution 1453, which authorized the United States to exercise legal power in Iraq, as well as to spend any Iraqi funds.
} 
and other local leaders to inform them the idea of an interim government with real sovereign authority had been indefinitely post-poned; instead, the Americans and their allies would remain in control of Iraq and the CPA would exercise all executive, legislative, and judicial power; manage ministries; and supervise the drafting of the constitution. The long-term American occupation, which many Iraqis warned against and which Garner had resisted, had begun. (Marr, 2012: 260, 266)

Almost immediately, Iraqi leaders (both former exiles and internal ones) were warning of potential resistance if an interim government was not established soon. One Iraqi warned, "This gives fuel to all those extremists who said the U.S. had a secret agenda to occupy Iraq and exploit its oil resources." (Diamond: 37) A key element in counter-insurgency is establishing a local government that can stand on its own so the people believe in their leaders. U.S. Army Field Manual 3-24, General David Petraeus's best-selling ${ }^{117}$ doctrine for counter-insurgency operations, argued, "The primary objective of any counter-insurgency is to foster the development of effective governance by a legitimate government." (www.fas.org/irp/dodder/army/fm3-24.pdf) The comprehensive RAND study of previous occupation efforts had recommended local elections be permitted early on, as had been the case in Germany and Japan, to be followed by national elections later. It also warned it was important to establish new national leadership sooner rather than later, since Iraq had neighbors that could interfere in the election process. (Maulucci: 122) But the CPA never held local elections and never pressured (or allowed) the Iraqis to hold them. At a higher level, Iraq went more than a year with no national leaders. In immediate post-conflict conditions, insecure citizens often turn to nationalist, ethnic, and other identity-based parties to protect their interests, and the more moderate parties tend to get squeezed out. Inside the CPA, and among most external experts on post-conflict transitions, there was widespread agreement Iraq would not be ready for national elections anytime soon. CPA officials and outside analysts felt time was needed to allow the moderate, secular, and democratic parties in Iraq to

\footnotetext{
${ }^{117}$ At one time, FM 3-24 was one of the Top 20 books on both Amazon and Google Books.
} 
develop their identities and capacities. They believed it would be many months before an Iraqi electoral administration could be appointed and organized to register voters and certify the eligibility of parties and candidates to contest the elections. (Diamond: 79)

It was not merely a political judgment imminent elections would favor Islamic parties (though the concern existed), but the principle belief that for elections to be fair, a level playing field would have to be established for the competing parties. External experts advised, however, starting elections on a larger scale would be a mistake. Though elections are an important benchmark in progress towards democracy, if they are held too early at the national level, they can strengthen extremism and rejectionist forces. Previous case studies, including Germany and Japan, demonstrate elections should start at the local level to allow the new balance of social and political forces to emerge and coalesce. Rather than moving rapidly to a national, party-based parliamentary election, transitional authorities in Iraq were advised to focus on developing democratic building blocks, such as free press, the rule of law, and local elected authorities. (Dobbins, et al: 191, 205) But Bremer and his top governance staff were deliberately resisting calls, and even vetoing plans for, direct elections of some local and provincial councils. (Diamond: 79-80)

Had a major effort been launched by early summer 2003, elections for a constitutional assembly could probably have been held by the spring of 2004 using the existing provinces as multi-member districts, or foregoing districts altogether. With adequate provisions for security, the UN could have helped prepare for such elections. However, the United States, as well as some Kurdish and Sunni Arab political leaders, feared early elections would give advantage to radical Islamic political forces, which were better organized initially than their more moderate or liberal opponents. Also unsettling was an August poll of Iraqi public opinion commissioned by the United States. While Iraqis overwhelmingly endorsed such basic democratic principles as free and fair elections, free speech, and even equal rights for women, $87 \%$ wanted religious groups to share power in government and $56 \%$ wanted religious 
leaders to play a role in politics. Only a minority preferred simply "a democracy". In addition, most Iraqis seemed unfamiliar with the new crop of politicians (the danger of using exiles and insisting the leadership be perfectly representative, rather than selecting actual leaders from society). 18 of the 25 members on the Interim Governing Council were so obscure 2/3 or more Iraqis did not know enough to offer an opinion on them. ${ }^{118}$ (Id: 48)

The CPA's refusal to consider early elections raised concern among many observers, including the United Nations. The first UN envoy in Iraq, Brazilian diplomat Sergio de Mello, who had been hearing a rising chorus of protests from Iraqis over the slow pace of the political transition, keenly felt the aspirations of Iraqis to elect the members of any constitutional-drafting body. In July 2003, De Mello proposed a voter registration drive begin "in the near future to demonstrate that tangible steps are being taken to pave the way for elections." But the recommendation was a non-starter for Bremer. ${ }^{119}$ On September 8, he reiterated early elections were simply not possible, as there were no voter rolls, no election law, no law on political parties, and no electoral districts. ${ }^{120} \mathrm{He}$ argued, moreover, "electing a government without a permanent constitution and defining and limiting government powers invites confusion and eventual abuse." (Id: 46-47)

The Shiites wanted elections right away because they felt early elections would finally bring them power. Members of other groups favored more time in order to guarantee peoples' rights. One of the most powerful and influential Shia clerics, Ali al-Sistani, was initially a "quietist" who did not want direct rule by the clergy but did want to ensure the new Iraq was an Islamic state. He became extremely influential in the summer of 2003, but he would not speak with CPA officials directly. (Marr: 280) Sistani issued a call for an elected constitutional assembly in early June 2003, which Bremer ignored. Such

\footnotetext{
${ }^{118}$ Ahmed Chalabi was the only member whose unfavorable ratings exceeded his favorable ones.

${ }^{119}$ Bremer speaks highly of De Mello in his book, My Year in Iraq, saying he truly valued the UN envoy's advice and input. De Mello was killed in August 2003 when insurgents bombed the UN compound in Baghdad.

120 This begs the question then why-as the extreme and nearly-absolute power within the country-Bremer did not simply draft and implement such laws for the short-term, as was done in Germany and Japan.
} 
defiance had far-reaching, ominous implications, as Sistani was the most revered moral authority in Iraq. The CPA's early failure to grasp Sistani's wide popular support base cost the occupation dearly in time and credibility. On June 30, four weeks after his initial statement on his desire for early elections, Sistani issued a fatwa-a legal pronouncement by an authority in Islamic law, which becomes incumbent on all believers-declaring Bremer's plan for an appointed body "fundamentally unacceptable" and that general elections must be held soon so every eligible Iraqi could choose someone to represent them at a constitutional convention. (Diamond: 44)

Bremer again ignored Sistani and pressed ahead with his own plans. He reversed or vetoed plans put forth by local CPA officials to hold municipal elections in various localities. In mid-June, he canceled an American military plan to conduct elections in Najaf, a city of one million (and Sistani's home) and site of two of Shiite Islam's holiest shrines. The cancellation-which came after extensive preparations and the onset of voter registration-caused loud popular demonstrations. Later in the month, coalition military commanders were ordered to halt elections in other towns and cities across Iraq and use the CPA's preferred method of consultation and indirect elections to select local mayors and councils. Decent elections, Bremer said, required not just some measure of security, but a political consensus, a legal framework, and an administrative infrastructure. An electoral commission had to be chosen; voters, candidates and political parties had to be registered; party and campaign rules had to be established; polling stations had to be designated; procedures for voting and counting had to be defined; equipment needed to be procured; voters needed to be informed about the procedures, the issues, and the candidates; and electoral observers had to be accredited and trained. (Id: 45,137$)$

There were concerns among the populace about early elections, as well: how could they be sure of fair elections if the majority of people are poor? (The implication was poor, uneducated Iraqis would vote as their tribal chief or imam instructed.) Others felt elections would be pointless, since people 
would just vote for their own group, regardless of qualifications. ${ }^{121}$ (Id: 311) However, holding community or local elections first, even in late 2003 or early 2004, could have provided an opportunity for more local leaders to emerge and gain experience, and for political parties to build support bases. Then, meaningful authority could have been delegated to these elected bodies and the U.S. would have faced a more diverse and legitimate array of Iraqi interlocutors. These local bodies could then have served as a basis for selecting the interim national government and constitutional drafting body.

Between May and November 2003, provincial and local councils had been constituted by a variety of means. In a few cases, councils were simply appointed by the U.S. military commander; in others, CPA officials and civil affairs officers of the coalition's local military command negotiated to find the right balance. In some provinces, a caucus of representatives and notables identified by the CPA elected council members. The only method explicitly ruled out was direct elections, despite the call of many Iraqis and the preference of several CPA officials in the provinces for this approach. By common consent, no one seemed to comment on the paradox of trying to create a democracy by appointing local leaders. (Van Buren, 2011: 57)

Partly because of their history and culture, and partly because the CPA did such a poor job of engaging them, Iraqis generally suspected the worst of the Americans. The suspicions were somewhat misplaced, as the CPA intended to organize as open and democratic a process as they thought was possible at the time (which, to them, meant free and indirect elections). Bremer and his most trusted CPA advisors simply did not grasp the depth of Iraqi disaffection, suspicion, and frustration, even among many of the U.S.'s partners and allies within the Iraqi political class. By failing to give them a democratic mandate, the CPA fueled the Iraqis' feelings of ineffectiveness and powerlessness. Some were asked to

\footnotetext{
${ }^{121}$ Democratic advisors in Iraq tried to assure the population these would always be concerns in democracy, but their words did little to assuage fears. The Iraqis had been isolated for seven months by this point, with no passports, Internet, or phones. Democratic groups in the U.S. who wanted to help were unable to contact anyone within the country.
} 
advise on reconstruction projects, or given small budgets to fix schools, promote public health, or control traffic, but for the most part, the deficits of resources and authority persisted. With no plan to hold direct council elections for at least another year, the legitimacy deficit was expected to widen again. (Id: 82, 117)

Bremer was right: ill-timed and ill-prepared elections, by themselves, do not produce democracy, or even political stability. In fact, they may only serve to enhance the power of actors who incite coercion, fear, and prejudice. But such risks should be weighed against the repeated reneging of promises. Little consideration seems to have been given the consequences of reversing processes favored by the Iraqis and the perception these actions would create in a country where honor weighs heavily.

Iraq: Forming a New Government

Before being relieved of authority, Garner appointed a seven-member Leadership Council comprised of the heads of the key exile parties behind the Baghdad Conference; however, Bremer did not have much faith in the exile opposition leaders-he wanted a broader leadership base with specific consideration given to ethnic, sectarian, and gender diversity. Much of Bremer's first two months in Iraq was spent negotiating with the original seven-member Council: he did not want to surrender real power, but he needed to include prominent Iraqis to have legitimacy within the population. Through June and the first part of July, Bremer held frequent discussions in search of a formula to widen the initial Council into a more diverse Iraqi advisory body. In an attempt to enlist some of the local population, CPA teams fanned out across all 18 provinces in Iraq searching for individuals who could represent communities in the temporary administration, but the process was ad hoc at best. Bremer faced steadfast resistance from Iraqis who kept warning of the dangers of an extended occupation and who kept demanding real governing power. (Diamond, 2005: 40-41; Marr: 266, 271-72) 
The two main Kurdish parties were not interested in joining the new council and the Shia were becoming increasingly explicit in their desire to reverse decades of political discrimination through a unified majority. There were also trends in the Sunni community, though these were somewhat more divided. Since most Sunnis felt ostracized by Bremer's de-Baathification measures, they refused to participate in the political process. Many insiders did not trust the exiles, who were largely secular and westernized. Each group promoted their members from within and vetoed potential council members from the other constituencies. Eventually, Bremer announced a 25-member Governing Council (GC) on July 13, 2003, which he promised would consult and coordinate on all matters involving the temporary governance of Iraq. The group was still dominated by the exiled opposition. Thirteen were Shia, five were Sunni Arabs, and five were Kurds. One Turkman and one Christian were included. Three were women. The CPA also tried to give an edge to those parties characterized as more secular and liberal, though staffers recruited from a wide spectrum of political groups. (Diamond: 42; Marr: 271-72)

An ineffectual body, the Governing Council quickly became a source of increasing frustration for the CPA, even as the polls continued to show three-quarters of Iraqis believed their country was controlled by Bremer and his team. The political maneuvering on the Council was intense, as the members lobbied the Americans and one another in an attempt to establish positions within the new government. GC members spent their first two weeks arguing over the Council's leadership structure. They appointed a 25-member cabinet, but each GC member simply named ministers from their own party. They failed to agree on an interim president, ultimately deciding on a "rotating presidency" that changed each month. (Diamond: 26, 43; Marr: 272-73) The GC's exile majority also made it a fairly easy target for the likes of al Sadr, who denounced it as an arm of the American occupation (Diamond: 43) Bremer implored the Governing Council to develop a timetable for drafting a constitution and electing a permanent government, but the GC wanted the CPA to transfer power immediately. Without any clear deadlines or imminent elections, there was no incentive for the GC to exercise any 
responsibility; it was far easier to blame any problems on Bremer, since he held the real power in the country. As the process slowed, the Bush administration grew impatient. In September, Secretary of State Colin Powell set a six-month deadline for the Iraqi leaders to write a new constitution. (Id: 49-50) Virulent opposition to Bremer and the entrenched occupation began to appear on three fronts: the Sunnis, the Sadrists, and, most importantly, at home in the United States (Marr: 273-74). By September, relations between the GC and the CPA were frayed (Diamond: 50). Then, on September 8, 2003, in an op ed piece in the Washington Post, Bremer laid out his plan for a lengthy, seven-step roadmap to end the U.S occupation. ${ }^{122}$ It boiled down to three main goals: first, a constitution would be written and ratified by Iraqis. Next would come a national election. Only after that would the U.S. occupation authority be dissolved. The plan had one huge flaw, however-it lacked essential support in both the U.S. and in Iraq. It would take too long, according to those in the administration who wanted to accelerate a transfer of authority before the 2004 elections. U.S. officials began to realize they could not sustain an occupation for so long, but there was no other realistic plan for transferring power to the Iraqis. (Ricks: 254; Marr: 279)

High-ranking British aids were worried Bremer's plan was too slow and cumbersome (Diamond: 25) and Ayatollah Sistani-the most important religious and political figure in Iraq-declared it unacceptable to have the constitution prepared by unelected actors (Ricks: 254). In the face of growing opposition at home to the nation-building project and the forth-coming U.S. election season, the Bush administration abruptly decided in November 2003 to end the CPA and turn sovereignty over to an "Iraqi" administration by June 2004. Bremer's original plan was dropped (it had not been cleared by his superiors, anyway). On November 15,2003 , he revealed a new plan, abandoning the goal of having a constitution and general election before the U.S. government relinquished sovereignty; instead, the U.S.

\footnotetext{
122 UN Resolution 1511 mandated the United States present a plan by December 2003 for a transition to an Iraqi government.
} 
would officially hand over power less than eight months later. The plan consisted of a number of deadlines and steps for an interim government, and then a transition to a democratic government under a permanent constitution. (Marr: 258; Ricks: 255; Diamond: 51)

Bremer's new plan was startling to almost everyone involved in the reconstruction. Rather than a long-term occupation, the U.S. government was now seeking to depart Iraq as soon as possible. (Ricks: 255) The Governing Council and the CPA would go out of business by June 2004. It seemed the Americans had finally settled on a clear, viable plan for the transition. (Diamond: 52) Essentially, the U.S. proposed a national assembly to be chosen through a complex series of local caucuses, which would then pick a new Iraqi government. This government would be responsible for conducting a national election by March 2005 for a constituent assembly, whose sole purpose would be to draft a constitution and hold a referendum on it. If the referendum were successful, a second election would be held in December 2005 for a new national assembly, which would become Iraq's new constitutional government. ${ }^{123}$ To govern Iraq in the interim, the plan called for the CPA and the GC to work together to draw up a transitional administrative law (TAL) - basically, a provisional constitution - by February 28, 2004. (Marr: 279; Diamond: 51)

The November 15 plan would not survive in its original form. It had been developed without much input from the Governing Council, and many of its members resented having it imposed on them with little scope for discussion or revision. Once again, the Iraqis complained the Americans were dictating, rather than building a consensus. (Diamond: 52) The Bush administration and Bremer believed the plan met Sistani's demand only an elected body could write the permanent constitution, but now he opposed the November 15 agreement because of its complicated caucuses and unelected interim government. Sistani wanted an early election, which was viewed as essential to bringing the Shia

\footnotetext{
${ }^{123}$ The plan, although allowing for an elected constituent assembly, postponed the drafting of the constitution for 15 months and the election of a new government for nearly two years.
} 
majority to power in the face of more secular, Westernized groups. Bremer, however, desired to see power in the hand of the more liberal parties. (Marr: 280)

Just two weeks after it was announced, the November 15 plan was in serious trouble. Sistani made clear his objections and many observers-including several key figures in the UN-worried the plan did not provide for a widening of the political process to bring in excluded elements, such as Sunni Arabs and Sadrists. (Diamond: $59,60,65$ ) The TAL became the subject of yet another power struggle between the CPA and the various Iraqi parties. (CPA undated: 44; U.S. Senate Subcommittee on Foreign Relations, 2005: 85)

Early January became a crucial time for the CPA. The ambitious schedule of the November 15 agreement was looming - the U.S. had less than two months to get the transitional administrative law written and adopted, and not much longer to begin organizing the complicated system of caucuses that would elect the members of the transitional assembly. The key problem was how to have the Iraqis choose a transitional assembly through some kind of representative means that did not entail direct elections. The caucus procedures were so complicated even many within the CPA had trouble understanding how they were going to work. Moreover, because the local and provincial councils had largely been appointed by the CPA, many Iraqis felt they would be manipulated to produce an assembly pliable to American will. (Diamond: 76-81) ${ }^{124}$

By mid-month, conferences and public meetings on Iraq's political and constitutional future were taking place around the country. The only permanent charter Iraq had in the past century was the 1925 constitution; all others were interim. The population was deeply divided over the issue of

\footnotetext{
${ }^{124}$ Larry Diamond is a political sociologist and leading scholar in the field of democracy studies. He is a professor of Sociology and Political Science at Stanford University and Director of the Center on Democracy, Development, and the Rule of Law. In 2003, President Bush and National Security Advisor Condoleezza Rice requested he become a senior advisor to the CPA. In this role, he repeatedly urged the rapid construction of an interim Iraqi government through a transparent and legitimate process of dialogue. On both the war and post-war activities, the Bush administration ultimately pursued policies very different from what Prof Diamond recommended.
} 
federalism, polarized between the beliefs each cultural group or geographic region should have the right to determine its future and the desire for one nation. No amount of outreach or explanation could erase the Iraqis' fundamental objections: the members of the Governing Council represented only a small segment of the people. The members of one provincial council said, "You are speaking of democracy, but the Governing Council was not elected. We were elected, and this transitional law is being forced on us." ${ }^{125}$ The United States was finding itself on the less democratic side of an argument: Sistani called for an elected constitution-making body, Bremer said an appointed body would do; Iraqis wanted to conduct direct elections for local government, Bremer and other top officials vetoed them; the CPA proposed an opaque, convoluted process for choosing a transitional government, while many Iraqis desired direct, transparent elections. (Id: 128, 198, 201-02) It was clear the U.S. chose this path because it was more beneficial to the parties they deemed desirable.

It was not just a matter of drafting a temporary constitution; CPA officials felt the TAL would serve as a founding document and institutional framework for the future of Iraqi democracy, and thus should have broad public understanding and support. Increasingly, in both Baghdad and Washington, the Americans were looking to the UN to save the situation. The new UN Special Envoy to Iraq, Lakhdar Brahimi, pushed Sistani to accept a process in which the caucuses would be scrapped and an interim government chosen by June 30,2004 , with a transitional assembly then directly elected by the end of the year-several months earlier than under the American plan. This approach quickly gathered support among key Iraqi players, who feared the caucus system might deny them a victory they could win

\footnotetext{
125 The question also arose regarding the remaining authority of the provincial councils, who were continuing to meet but no longer had any real power. The concerns were valid: a local government order had been drafted by the CPA in August 2003, but it was never promulgated. (Diamond: 207)
} 
through elections. The CPA had little choice but to accept this compromise, though it expressed concern over how the caretaker government would be selected. ${ }^{126}$ (Id: 83, 137-38; Marr: 282)

A preliminary draft of the TAL_-prepared in coordination between the CPA and the more liberal members of the GC-emphasized civil rights, a central government with an independent judiciary, and separation of powers. Little was said about Islam or Islamic law. (Marr: 281) Though promising in some respects and liberal in intent, the initial document was full of holes and left many issues still to be resolved. The draft needed stronger, more explicit, and more detailed protections for civil and political rights. Additionally, the draft appeared to give sweeping decree authority to a three-member presidency council while anticipating a powerful prime minister. It also envisioned a weak and passive parliament. CPA staff identified nine issues they felt needed work: human rights, the judiciary ${ }^{127}$, federalism, the executive structure, legislative power, civil-military relations, the method of selection of the transitional assembly, the office of public integrity, and the transition timetable. It soon became clear the question of who would be part of the caretaker government would have to wait until the interim constitution was approved. (Diamond: 139-141, 145)

Shia groups quickly began demanding (and ultimately prevailed) the TAL include a provision forbidding the passage of "any law that contradict[ed] the universally agreed tenets of Islam" during the interim period. ${ }^{128}$ (Id: 122) Another provision to the TAL mandated the electoral law "aim to achieve the

\footnotetext{
${ }^{126}$ Brahimi's full report was released on February 23, 2004. He noted concern for the rising level of violence, a growing fragmentation of the political classes along ethnic and sectarian lines, and rising disillusionment and anger over widespread unemployment and the limitation of the political arena to a narrow range of participants. ${ }^{127}$ By mid-January 2004, the CPA-appointed judicial review committee assembled roughly 600 Iraqi judges, expelling 120 of them for incompetence, corruption, or high-level Baathist membership, but ratifying the rest to continue in office. Somehow, in one of the most brutal dictatorships on earth, a relatively decent judiciary had persisted. It seems Saddam did not need to transform the courts into a comprehensive instrument of oppression; he simply tried, sentenced, and executed any potential offender on the spot.

${ }^{128}$ Language was also added forbidding laws contradicting democracy or fundamental human rights, but did not address the question of what would happen if there was disagreement between the two provisions. According to one sheik, "In Shiite Islam, leadership comes from Allah, but Allah will not choose directly. When the people elect a leader, he will be the man selected by Allah. So there is no contradiction between Islam and democracy."
} 
goal of having women constitute no less than one-quarter of the members of the National Assembly" ${ }^{129}$, as well as ensuring fair representation for various ethnic minorities. The language "aim to achieve" was weaker than the CPA wanted (even though the U.S. has no such law), but staffers were convinced they could later craft electoral system rules to ensure this goal. (Id: 147, 156)

Gender issues turned out to be a sensitive subject during the TAL discussions. One of the few female members of the Governing Council moved to repeal Decision 137, a law passed in December $2003^{130}$ that replaced the Iraqi Civil Law on family matters with provisions of Islamic shari'a law. ${ }^{131}$ When the majority of the GC agreed to repeal the decision-in a 15 to 10 vote-a delegate from one of the largest Shia Islamic parties left the meeting, claiming "the majority wants to force things on us and does not operate by consensus". Eight other Shia Islamic members followed. As a result, the February 28, 2004 deadline came and went without approval of an interim constitution. (Id: 172)

The bargaining was tense even before things unraveled. For weeks, the CPA had been negotiating with the Kurds as a group, but refusing to do so with the now-unified Shiite caucus. For decades, Kurds suffered periodic Arabizing pressure, escalating into a large-scale campaign of displacement and deportation under Baathist rule, reaching a level of ethnic cleansing during Saddam's last 20 years of rule. Kurdish homes and properties were given to Arab settlers, but after the fall of the regime, tens of thousands of Kurds poured back into northern Iraq to reclaim their property. The CPA's strategy for dealing with the Kurds had three basic dimensions: first, the Kurds' attempt to reverse Arabization by force and intimidation had to cease; second, status of regional oil revenue ${ }^{132}$ had to be post-poned until the end of the transition; and third, a system of due process had to be established to resolve the issue of the now-displaced Arab citizens in the north. Even though it directly contradicted

\footnotetext{
${ }^{129}$ Women are $60 \%$ of the population of Iraq, but there had been no significant role for women in the occupation government, even on the Governing Council.

130 This session of the GC was exceptionally poorly attended.

${ }^{131}$ Shari'a law is widely viewed as limiting women's rights to divorce and inheritance.

132 The northern oil fields of Iraq account for half of the country's oil production.
} 
the CPA's position that all independent militias should be included in plans for demobilization, the Kurds were adamant about keeping the pesh merga as an independent force, viewing it as their ultimate defense against renewed oppression from Baghdad. Shiites began to ask, "If the Kurds can have it, why can't we?" Thus, some Shiite political leaders wanted to give the Kurds most of what they asked for, if only so the Shiites could have it, too. (Id: 164-65, 167, 171)

Bremer and his CPA colleagues finally managed to draw the Kurds away from their initial untenable vision into a framework of federalism; then, things blew up. After weeks of not receiving a response to its cables to Washington reporting on the TAL negotiations, the CPA received instructions from the Bush administration to remove any reference to the Kurdistan Regional Government from the TAL and that Iraqi federalism had to be based solely on the 18 geographic provinces. Upon hearing the news, the Kurds were understandably furious, feeling they had been double-crossed by the CPA. They retreated to an extreme position on every issue: regional powers, the pesh merga, due process, and oil rights. In the end, the central government was given management of all the natural resources in Iraq, which were declared to belong to all the people. It was required, however, to consult with lower-level governments to distribute the resulting revenues "in an equitable manner proportional...to the population...and with due regard for areas that were unjustly deprived...by the previous regime." (Id: $166,169)$

Following the Shiite walk-out on February 27, Bremer instituted a 72-hour marathon meeting of the Governing Council to try to finish the TAL. Deliberations quickly broke down along ethnic/sectarian lines; at one point, the Sunni members wanted to stage a walk-out of their own. A late-arising contentious issue was whether former Baathists would be able run as candidates in the next year's elections. The Shiites said no, while the Sunnis wanted looser restrictions than those implemented by the CPA during the occupation. It was finally agreed only Baathists at the division level or above would be excluded. Then, in the final hours of the session, a Kurdish member proposed ratification of the 
permanent constitution should require more than a simple majority vote: it would be defeated if twothirds of the voters in three or more provinces rejected it. The other exhausted members of the Council quickly adopted the provision. What appeared to be an innocent, last-minute addition proved to be a brilliant tactical maneuver. Though only $20 \%$ of the population, by basing the voting on the 18 provinces, three of which were predominantly Kurdish-the Kurds ensured they could defeat any seriously objectionable constitution. The TAL was to be signed later that day in an elaborate public ceremony, but when the Shiite leaders realized what the Kurds had done, they refused to show up. In what was one of the most embarrassing moments during the 14 months of CPA rule, the TAL signing was post-poned for the second time. Five days later-and only after extensive consultation with Ayatollah Sistani-the Shiites agreed to sign the document. (Id: 173-76)

Any celebration was short-lived, however; after the ceremony, one of the Shiites read a statement on behalf of 12 of the 13 Shia members of the GC, declaring their intention to "amend" certain provisions of the TAL they felt were "undemocratic". Even though there was no legal mechanism for them to do so, the speaker asserted they had signed the TAL only to honor an agreement they were dubiously coerced to enter and through a desire to preserve the unity of the country, but they would seek to make changes before the June 30 transfer of power. He further warned the TAL would lack legitimacy until approved by a democratically elected national assembly (which was not part of the planned agenda). (Id: 177)

Iraq: The Transitional Administrative Law

The TAL received mixed reviews from the press. Local Iraqi media coverage of the TAL was positive. Smaller Iraqi publications - assisted by the United States-expressed pride in the completion of the document. External media outlets were dismissive, focusing on the Shiite/Kurdish divide. Some Iraqi commentators were also skeptical, complaining the law had been drafted and negotiated in secret by 
the Governing Council and the CPA. Others argued the GC, as a non-elected body, did not have the authority to adopt even an interim constitution. Articulate, politically aware Iraqis let lose a torrent of questions, objections, and passionate opinions. Many appreciated some aspects of the TAL, but most of the commentary was critical. People repeatedly asked why the draft of the TAL had not been submitted for consideration by civil society organizations, political parties, religious leaders, and the general public. CPA staffers suggested to Iraqis that since the TAL was purely a transitional document, they would be better served to focus on the future constitution, but this came across as the Americans trying to push aside Iraqi concerns. One complaint, heard again and again, was "where is the Governing Council? Why aren't they out selling and defending this law, rather than the CPA?" (Id: 179-85; 197-98)

To promote public acceptance, the CPA prepared to release one million pamphlets highlighting the key themes of the TAL. The pamphlet preceded the launch of a civic education program of weekly flyers with a series of themes on democracy. Before the CPA could distribute its leaflet, however, a detailed critique of the law entitled, "What Do You Know About the TAL?" was crudely produced and circulated among the population. ${ }^{133}$ The document was devastatingly effective at turning public opinion against the TAL. (Id: 183, 188)

Alongside the print materials and dialogue, the CPA developed a comprehensive communications enterprise. With the aid of opinion polls and focus groups, these messages were meant to sell the TAL and create public understanding, acceptance, and ownership of the transition process. The TAL television ads were imaginative, moving, and technically sophisticated. ${ }^{134}$ There was only one

\footnotetext{
${ }^{133}$ This opposition pamphlet read, in part, "This law paves the way to divide Iraq and deepen sectarianism in its future system and make Iraq fall into a stage of instability and violence...This law was made in coordination with the occupying power; we can see the fingerprints of that power clearly...This law was made behind closed doors under pressure of the occupiers on many of the Governing Council so as to finish it before the election campaign of Bush... The occupiers didn't allow to show the TAL to the Iraqi people to be discussed through public seminar and the media before signing it." [grammatical errors in original English translation]

${ }^{134}$ Television reached about $90 \%$ of Iraqi households, either through the Iraqi network or through Arab satellite outlets like Al-Jazeera.
} 
problem with them: they came too late. Bremer did not grant approval to create the ads until March 16, 2004; by then, the TAL was already a week old and the opposition pamphlet was flooding the nation. It would be weeks before the ads were produced and aired. ${ }^{135}$ (Id: 189-90)

On March 26, 2004, Bremer met with his regional and provincial CPA officers, who reported problems with articles of the TAL, the peoples' frustration at the lack of participation in the process, and the grumbling that members of the Governing Council never came before the people to explain and defend the document. Bremer shut the door firmly on any discussion of amendments or changes to the process. The TAL was finished, he said. The negotiations had been excruciating, and the TAL was one of the CPA's most important achievements. A few days later, the intense Sunni and Shiite insurgencies broke out in the center and south of the country, which threw all CPA operations into chaos, and the ad campaign was temporarily suspended. The CPA once again lost the initiative to an opponent who understood the Iraqi culture and society to a degree the CPA would never approach. (Id: 191, 203-04)

Two-thirds of the Iraqis contacted refused to even discuss the TAL. In addition, many felt there was little the TAL could do to achieve the rule of law if security did not improve. This information was precious feedback, but the CPA lacked the mechanisms (and, at this point, likely the will) to adjust its actions and policies in response. One USAID official who worked with the process later said, "You have to accept that the initial stages of democratization are horribly inefficient. You need to allow a lot of time for people to talk." ${ }^{136}$ (Id: 210)

By the time of the handover, USAID reported they held more than 15,000 democracy dialogues, with a reasonable estimate of 300,000 Iraqis participating. But since these participants came from the

\footnotetext{
135 Individuals like Sistani could reach the Iraqi people far more rapidly and effectively than the CPA, with its cumbersome communications machine and endless bureaucracy.

${ }^{136}$ More than \$2 million was committed for USAID's civic education program, but if civic education must be reinforced by what people experience in real life, than what the Iraqis observed was an interim constitution drafted and adopted without national debate, a postponement of direct elections, another round of appointed government, and perpetuation of control by the Governing Council.
} 
most-educated stratum of society (doctors, lawyers, teachers, and other professionals), it could be argued the dialogues never cracked the tougher challenge of engaging the masses of poor Iraqis in the rural areas and urban slums serving as recruiting grounds for the insurgency. At the end of March 2004, USAID's initial summary of feedback regarding the TAL showed a mixed reaction, but "generally more critical than supportive". Iraqis were disillusioned and frustrated with the "process used to develop and adopt the TAL". Many noted the contradiction pervading many aspects of the American occupation between the declared democratic intent and the lack of opportunity for democratic participation. Provincial councils wondered why their opinions were even sought, since the document was already signed. (Id: 209)

Violence was rising throughout the country. CPA officials would schedule extensive programs, including meetings with political party leaders; Q\&A lunch sessions with sheikhs, university students, and professors; and dinners with local NGO representatives, but have to cancel at the last minute due to lack of security. Grand ambitions for promoting the TAL and educating Iraqis about democracy were ground down by the realities of a shortage of resources and people, the makeshift character of the organization, the cumbersome pace of CPA processes, economic and civil devastation, and the relentless and escalating violence. Administrative control and feedback broke down as staff members were recalled from provincial offices around the country, including the entire southern region. (Id: 194, 208)

\section{Iraq: The Caretaker Government}

On April 4, 2004, UN Special Envoy Brahimi returned to Baghdad to begin the delicate task of constructing the interim government taking over for the CPA on June 30. The Bush administration considered UN involvement vital if the interim authority was to have the international and domestic legitimacy it would need to govern post-war Iraq. The Governing Council, however, did not see it that way. The core of the Shiite caucus resisted the UN's return, worried a Sunni Muslim like Brahimi would 
want to ease de-Baathification. Seeking to preserve their dominance, they determined their best option would be to construct the interim government themselves through direct negotiations with the Americans. The UN played into their plans by insisting on a formal letter of invitation from the Iraqis before they would mediate the transitional challenge. ${ }^{137}$ In the end, the Iraqis wrote the letter, but it was far from enthusiastic. Sistani also wrote to the UN, stating the Shia would not meet with Brahimi without assurances the TAL would not be recognized in any Security Council resolution. ${ }^{138}$ (Marr: 282) When Brahimi and his team began negotiations to form the interim government, only three parties were at the table: the UN, the CPA, and the Governing Council. No outside constituencies or civic groups were present. ${ }^{139}$ Brahimi wanted to cut the exile politicians from power and force them to run in the later elections. He said leading officials of the interim government should separate themselves from partisan politics by agreeing not to be candidates in the coming elections. For several members of the GC, such an act of self-sacrifice had yet to be seen. (Diamond: 246-53, 257)

For the interim president, both Brahimi and the State Department favored Adnan Pachachi, a former foreign minister and respected liberal who opposed Chalabi's views. Pachachi publicly rejected the position, however, stating he was tired of being portrayed as the "Americans' choice" when he had spent his life fighting for Arab rights and unity. Because of his portrayal by the CPA, Pachachi felt his reputation was compromised and he could not be effective in the new government. This was an additional frustration for Brahimi, who was then forced to turn to Bremer's first choice, Ghazi Al-Yawar, an exile politician who publicly thanked President Bush for over-throwing Saddam. (Id: 40-41; 261)

\footnotetext{
${ }^{137}$ During this time, the UN was struggling with reports suggesting massive corruption in the oil-for-food program. There were also reports from an independent investigative panel that lapses in UN security management contributed to the death toll in the August 2003 bombing of the Baghdad mission that killed UN Envoy Sergio de Mello.

${ }^{138}$ Sistani's concerns were genuine, as the U.S. intended to seek formal recognition of the TAL in the same Security Council Resolution endorsing the interim government and formally recognizing Iraqi sovereignty, making it much more difficult for the new government to drift away from the TAL's provisions.

${ }^{139}$ Brahimi soon expressed frustration and disappointment over his role in Iraq, going so far as to call Bremer a "dictator" (Lasseter, 2004). He resigned as the UN Envoy on June 12, 2004 (Shamir, 2004), more than two weeks before the official transfer of sovereignty.
} 
In regards to the position of prime minister, many lobbied hard for the job. By this time, Chalabi had alienated many of his colleagues and fallen out of favor with U.S. authorities. ${ }^{140}$ The favorite was a Shiite Islamist, Dr. Adel Abdul Mehdi. He was the leading technocrat among the exile parties, but Sunnis feared he would try to impose Islamic law and so he was ultimately vetoed by too many powerful players on the GC. Of the remaining Shia candidates, two were viewed as too religious, leaving only Ayad Allawi as a potential candidate. Bremer informed the GC Allawi was chosen on May 28, 2004, and they reluctantly—but unanimously—endorsed him. The religious Shia parties had a member named vicepresident and another as finance minister. The Kurds received the other VP slot, as well a newly-created deputy prime minister position. Brahimi was permitted to choose the remaining 31 ministers, and he used criteria he initially hoped to use for the entire process: integrity, professional experience, and technical competence. Only six minsters had ties to large political parties ${ }^{141}$ and six were women. Those who served as ministers during the occupation were dismissed if they were suspected of being corrupt or incompetent, while those who had built a record of accomplishment were permitted to stay. ${ }^{142}$ (Id: 258-59, 262)

On June 2, 2004, the new Iraqi Interim Government was appointed and the UN recognized Iraq's full sovereignty, effective June 30 . On June $28^{143}$, Bremer handed over authority to the new government, which became the last appointed government in Iraq. Bremer then immediately left for the airport and flew out of Iraq. (Marr: 283)

\footnotetext{
140 Eventually, U.S. officials would order Chalabi's home and party headquarters searched for evidence of fraud and other crimes.

${ }^{141}$ Not a single member of the new cabinet was from Chalabi's party.

${ }^{142}$ For example, the new oil minister was a petroleum engineer who had been demoted under Saddam for supporting reforms.

${ }^{143}$ Due to security concerns, the date of the ceremony was changed from June 30 and kept secret.
} 


\section{Summary}

CPA officials in Iraq continually found themselves on the less democratic side of debates, favoring appointed bodies over direct elections. When steps to draft a new constitution were stalled due to internal bickering on the GC, Bremer allowed it to continue. The occupation seemed to be held hostage by both good intentions and ignorance: it wanted the new government to be developed by Iraqis, but it never gave those in power any motivation to move forward with such plans. Rather, it was to the GC's benefit to continue allowing Bremer to take the heat for all of the problems in the nation. Had CPA officials strayed from their determined path of complicated plans and lofty ideas long enough to study previous successful occupation efforts, they might have noticed neither Germany's nor Japan's first attempts at democracy went perfectly. In Germany, the initially successfully parties were the antithesis of who American hope to see in power. When the Japanese caused delays in constitutional drafting, MacArthur did it for them. In both cases, the choice was clear: local citizens needed to learn by doing, and they needed to do it fast. While this may seem counter-intuitive, it does drive home the key point individuals in Iraq kept missing: democracy is messy, and politics is about decision-making and prioritizing. Again and again, Bremer and his staff aimed for the perfect ideal: a perfectly representative government with a unanimously agreed-upon structure. Not even the United States, the world's most long-standing democracy, has ever reached this level of achievement. So, why did anyone think Iraq could attain this goal right out of the gate?

This work is the first comprehensive comparison of the steps towards a new constitution and the first round of elections in post-conflict Germany, Japan, and Iraq. The lessons learned in 1945 should have been obvious (and, in fact, were recommended by several experts; Iraq now stands to illustrate this to an even stronger extent). First, local, direct elections are an important stepping stone, and occupation authorities should not wait for more desirable parties to form. If the people are unhappy with their options, they will work to make more. Second, occupation officials should use the power they 
have to move the democratic process along. If there are no election laws, draft them; no voter rolls, create them. All this can be done while still making it clear the new government will have the power to implement new laws, as appropriate. Finally, potential (and hopeful) national leaders must be held accountable. The Iraqi GC should never have been allowed to hamstring the democratic process for as long as they did, and Bremer made a serious error in attempting to rely on such a large ( 25 member) and self-serving body. It was clear as early as July 2003 the GC was not going to be effective, and it should have been scrapped then. But the CPA, once again, found itself on a decision path it was unwilling to reverse. 


\section{CHAPTER 6 \\ GERMANY, JAPAN AND IRAQ: FIVE-YEAR POST-CONFLICT STATUS}

First, and probably most important, an occupation has an objective. In the abstract, it may only be to assume executive, legislative and judicial authority in a defeated nation; but, as any actual war is likely fought for some more significant purpose than merely to win, an occupation is like-wise entered into for some reason other than merely to govern.

\section{Germany and Japan}

For the U.S. forces in Germany after World War II, the principal objective was to "prevent Germany from ever again becoming a threat to the peace of the world" (JCS 1067). This objective was set at the height of the war, with an eye more to the past than the future. JCS 1067 became a directive admirably suited to preventing a repetition of the 1920 s and 30 s, but inadequate to meet the situation of the late-1940s. After 1945, Germany was not likely again to rank as a major threat to world peace. Consequently, the U.S. authorities in Germany, left without a valid principle objective, were compelled to exploit loopholes and improvise. (Ziemke, 1975: 445)

In Germany, denazification was the chief, and certainly the most energetically pursued, tactical objective of the early occupation period. It was also probably the least satisfactory of all military government undertakings. Both denazification and the reverse of the coin, democratization, provided the basis for observations on the role of an occupation force as an instrument of social and political change. Denazification gave the Army the mission of carrying out a radical experiment not yet undertaken in modern times: the removal of a source international conflict. (Id: 446) But as worthy as denazification was in principle, it was not (as military government was painfully aware) realistically conceived. Conducted as a full-scale social revolution, it imposed dangerous strains on the structure of the occupation without necessarily promising any future returns other than more trouble. Before the end of 1945, total denazification on the terms originally envisioned proved impractical. In the long run, if 
less had been attempted, more might have been accomplished. The military government attempted to strike a balance between the return of sovereignty and resistance to the impending Soviet expansion with the need for denazification, but the former was in ascendance by 1948. (Dobbins, et al, 2003: 16)

The democratization program, however, provided an example of a different sort. By not attempting as much, it accomplished more. The majority military government opinion at the time would have favored an extended period of tutelage. If this view had prevailed, the outcome might have been the same as with denazification: a train of increasingly expensive and frustrating programs ending in mutual disappointment. General Clay made democracy as attainable an objective for U.S. forces as it was ever likely to be by placing responsibility for its attainment where it would ultimately have to lie: the German people. (Ziemke: 445) By 1947-48, the United States, and then the British and the French, continued to return more authority to the German people. In 1949, the Western allies permitted the first country-wide elections. (Peterson, 1977) The Cold War between the Western Allies and the Soviet Union gave a new imperative to the long-term continuance of the British and American garrisoning of Western Germany. The tension also gave a new direction to Anglo-American occupation policy, with the German nation mutating from potential enemy into possible ally. It now became Anglo-American policy to rebuild Western German's industrial strength and economic prosperity, while at the same time progressively empowering its new democratic institutions. (Barnett, 2005: 15-16)

In addition to the dispute over civilian rather than military control, the occupation of Germany exposed a built-in military government proclivity for muddled command channels. World War II produced two distinct and, unfortunately, not entirely compatible modes of military government: one territorial, with its own chain of command, the other integrated into the tactical channels. But the experience in Germany demonstrated both arrangements were necessary in successive stages of the occupation. (Id: 447) The division of Germany into four occupation zones with independent political, economic, and military authority took 45 years to overcome, largely because the German question 
became tangled in the Cold War struggle. Even reassembling the three Western zones took nearly half a decade, lengthening the occupation and slowing many reforms. Consequently, it is clear divided countries can be very difficult to put back together-even among allies. (Dobbins, et al: 22)

Not every Nazi received the just desserts due him, but most did. Not all Germans were converted to democracy, but they were given the opportunity for democracy without any snares or tricks. The tenor of some policy statements was harsh-even to the point of being vindictive-but the practice was as humane as a defeated army had the right to expect after a long and destructive war. (Zeimke: 448-49)

In Japan, the initial plan was for the occupation to last three years, but by early March 1947, General MacArthur believed the military objective of ensuring Japan would never again menace international security had been achieved and a framework established for a new democratic system. He advocated work begin on a peace treaty; however, the beginning of the Cold War and Soviet insistence on having a say in the content of the peace prevented further progress, so the U.S. occupation continued. (Dobbins, et al: 45) Japanese criminal law was modernized in by the fall of 1946, and in October of that year the National Public Service Law aimed to create a "technically sound, modern, and progressive civil service system" (GHQ/SCAP/Government Section 1949a: 19). From that point forward, promotion in public employment was based on merit and access was through open competitive examination (Bridoux, 2011: 135). After initial reforms were completed in mid-1947, MacArthur encouraged the Japanese government and agencies to reassume the normal powers of government for all domestic affairs, with the exception of the economy. The Japanese bureaucracy gradually became stronger than ever. (Dobbins, et al: 39-40) Then, the occupation and reconstruction of Japan did an about-face. The punitive and liberal reformist program based on demilitarism and democratization made room for a program of 
economic recovery aimed at self-sustenance, strengthening of the state apparatus, and policing of the civil society.

Global and regional factors played a role in the reversal of American policy regarding Japan. At the global level, there was Soviet domination in Eastern Europe and assertiveness in other parts of the world, especially the Middle East and the Mediterranean, combined with the economic crisis shaking Western Europe and the need for an extended American involvement there. Regionally, the dreadful state of the Far East economy and the everlasting desperate economic conditions in Japan also required a change of approach in the U.S. occupation. (Bridoux: 142) Domestically, the change in policy was driven by shifting public opinion. Newsweek's foreign affairs editor, Howard Kern, began to attack the deconcentration of economic power and asserted the purge program would disrupt economic recovery by removing leading figures in industry, commerce, and finance (Kern, 27 January 1947). Soon, planning documents started to change the orientation of the occupation objectives. These documents insisted on the self-sustainment of the Japanese economy to alleviate the burden on the American taxpayer, Japan's fast integration in the global economy, greater economic control for the Japanese, and the cessation of reparation payments by Japan. (JCF-I 1977: Reel 6, SWNCC and SANACC 1977: Reel 26, 31)

On December 10, 1948, the U.S. government issued an interim directive to SCAP, instructing MacArthur to direct the Japanese government to undertake an economic stabilization program designed by Detroit banker Joseph Dodge. Its principal component was to balance the consolidated budget, which had been in substantial deficit. This very tough program prohibited expenditures for which there was no proof of revenue to cover the costs. The Japanese government was not allowed to provide any new subsidies. The Dodge Plan, launched in 1949, was followed by massive lay-offs of government and industrial employees; increased taxes; wage freezes; higher prices for rice, transportation, and other government-subsidized goods and services; and reduced public services. The immediate effect was a wave of strikes, demonstrations, and sabotage. (Dobbins, et al: 50) 
The scope of the earlier political purge put the operational efficiency of the Japanese state at risk, pushing the occupation to review its purge policies following the Reverse Course in 1947. The will to democratize through punishment of those officials and bureaucrats who contributed to the functioning of the previous authoritarian regime was tempered by the need to build a strong Japanese political society able to resist internal and external challenges to its authority, especially the ever-growing Soviet threat. Consequently, the new American reconstruction policy encompassed no further extension of the purge. The de-Concentration Law and the Anti-Monopoly Law were amended, or simply ignored. The economic purge was stopped and-in some instances-people already condemned as war criminals were released from jail (Dower, 1979: 355; LaFeber, 1997: 274; GHC/SCAP 1990j: 28-9)

In July 1950, the Japanese reluctantly agreed to the U.S. request they establish a National Police Reserve of up to 75,000 men, which would function as a paramilitary force to fill the vacuum left by the rapid movement of all but one division of U.S. occupation forces to Korea. MacArthur had announced the aims of the occupation complete in 1947, and thought the continued presence of U.S. troops served as an irritant rather than a sign of stability. (Dobbins, et al: 35 ) Japan regained its sovereignty in April 1952.

Nearly all parties involved have deemed the U.S. occupation of Japan a success, as do those who today enjoy the fruits of those efforts. However, the positive results were not evident overnight, and the immediate effects struck many as chaotic. The occupation, which was presided over by an autocratic U.S. general, arguably had more success at demilitarization and democratization than it did at fostering a truly open and vibrant economic system. Yet, it also turned a former enemy into a reliable ally. (Id: 32)

$\underline{\text { Iraq }}$

In 2008, Iraq was still far from a functioning state. One Army colonel stated the U.S. had a better government in post-conflict Vietnam than they did in Iraq. A study done at the U.S. embassy concluded 
corruption was "the norm" in many of the Iraqi government ministries. Its extent could not be determined, however, because several ministries were so controlled by criminal gangs and militias it was impossible for the investigator to operate without a tactical security force. Most troubling, the two ministries determined to be most problematic were the Oil Ministry (which was loaded with revenue) and the Ministry of the Interior, which controlled police and other law enforcement, including border patrol. (Ricks, 2009: 216, 260)

Nothing better reflects the lack of a comprehensive vision for Iraq's occupation more than the inability of the Bush administration to make a decision on its fundamental nature (Maulucci, 2008: 128). In the 2000 presidential debates, then-candidate Bush warned about using U.S. troops as nation builders. He stated, "I believe the role of the military is to fight and win war, and therefore prevent war from happening in the first place." He believed the military was "over-extended in too many places" as a result of wanton Clinton administration policies. (Bush, October 3, 2000)

Disbanding the Iraqi Army and the purge of Baath party members exacerbated the first and main source of violence in Iraq, the Sunni Arab insurgency. Aimed at restoring Sunni Arab rule or at gaining local power and control, the Sunni insurgency's infrastructure, arms, and support essentially originated in Iraq when the exclusion of the Sunnis by the CPA led to the alienation of close to $30 \%$ of the Iraqi population. (U.S. Institute for Peace, 2006: Chapter 1) All contributed to a process of fragmentation of state power and the inability of Iraqis to reach national reconciliation. In fact, the scope of the purge initiated by the CPA (and later continued by the new Iraqi government), further weakened the Iraqi state as Sunnis, constituting the bulk of those with expertise, fled the country, depriving the state of the skills needed for its recovery. In turn, this impacted economic recovery and provoked Sunnis to fall back on their common identity as a form of protection. It translated into a reinforcement of the insurgency, which produced the exact opposite of purge's intent. Worse, the 
purge, as a source of violence, was enshrined in the Transitional Administrative Law (TAL), the document serving as the basis for a future constitution. (Van Buren, 2011: 169)

The revival of religion became a trend in 2004 Iraq, as many attempted to redefine Iraq as an Islamic, rather than a secular, nationalist state. Traditional Islamic practices increased, particularly pressures to enforce dress codes and other forms of restrictive behavior between the sexes. Impact of this social conservatism on the status of women was particularly evident. The TAL mandated a $25 \%$ quota for women to open doors for their participation, but in reality many women entered on political tickets were supporters of conservative Islamic positions on women's roles. According to the Ministry of Education, the ratio of girls to boys attending schools in the south dropped from 2:3 before 2003 to one in four after. Most striking, however, was the return to tribal customs embedded in "honor killings" for perceived immoral behavior. The UN Assistance Mission for Iraq expressed concern over the rise in these types of murders in Kurdish areas, and the same was true for the south. (Marr, 2012: 372-73) Traditional forces began running up against counter-trends, reflecting the influence of more secular, liberal ideas. This could be seen most clearly in the new freedoms given to the press and media, and to public expressions of differing views, as well as to the inevitable spread of information via the Internet, tying Iraq to the outside world. ${ }^{144}$

In March 2004, Stuart Bowen, the recently appointed Special Inspector General for Iraq Reconstruction (SIGIR), met with Secretary Rumsfeld. The Secretary's first words were, "Why did you take this job? It's an impossible task." Bowen did not understand this startling welcome until a week later, when he made his first trip to Iraq. What he saw was troubling: large amounts of cash moving quickly out the door. Later the same day, he heard someone say, "We can't do that anymore; there's a

\footnotetext{
${ }^{144}$ One of the Iraqi boys the author met in 2008 said he learned English by watching episodes of the television show Friends.
} 
new inspector general here." Over the next five years, SIGIR's office would initiate over 370 investigations into questionable contracting and reconstruction practices in Iraq. (Bowen, 2009: i)

The physical reality was the Americans lived ensconced in military bases, with only cursory relationships with Iraqis. They were seen as fat-walleted aliens descending from armored spaceships. Professionals, technocrats, doctors, and engineers who might have been partners in reconstruction were gone,${ }^{145}$ so the Americans were forced to rely on tribal leaders with self-serving agendas and corrupt officials placed in their jobs by the CPA. Assistant night managers of American restaurants were made small business advisors; an auto mechanic ran a vocational school. Hobbies and tangential skills were used in lieu of real project management experience. (Id: 248) True planning tended to flounder as U.S. personnel rotated out of Iraq. Most stayed no longer than a year, and the tendency was to believe the reconstruction effort started shortly before they arrived; memories rarely extended back more than a few months. But the Iraqis remembered-they were there for the last group, and would remain for the next one. (Bacevich, 2010: 86)

In November 2004, thanks mainly to U.S. efforts, the Paris Club agreed to write off $80 \%$ of Iraq's debt - a total of $\$ 30$ billion. Although the follow-through on this agreement was weak, the cooperation of the European creditors in alleviating Iraq's debt was a major step forward. But problems still remained with a number of Gulf neighbors, especially Kuwait, who was unwilling to forgive its debt or reparations. Then, it late 2004, the Sunni insurgency heated up again. Interim Government Prime Minister Allawi engaged in outreach to the insurgents, especially Sunnis, playing on his former Baathist ties. The government's aim was to separate the nationalists, unhappy with the occupation, from the foreign radicals, especially those linked to al Qaeda. Quid pro quo was offered in the form of more jobs in the administration and a stake in the political process through the coming election. However, these

\footnotetext{
${ }^{145}$ 20,000 of Iraq's 34,000 registered physicians chose exile. (http://www.brookings.edu/saban/Iraq-index.aspx)
} 
efforts ultimately failed. Instead, the Interim government's tenure saw a renewal of the confrontation between Multi-National Forces and al Sadr. (Marr: 261, 284)

The Falluja conflict renewed in November/December 2004. There was no doubt coalition troops and the new Iraqi security forces needed to go back in and clear the city. Fighting was hard-92 U.S. soldiers were killed, while more than 1,200 insurgents died. There were claims of 6,000 dead civilians, and another 200,000 who fled. The city had significant damage, with $20 \%$ of its buildings destroyed. The immediate fallout of the battle was political: Sunnis were incensed and increased their hostility toward the occupation and the election, for which campaigning was well under way. They began calling for postponement, and later boycott, of the election. (Id: 286)

Early notice reconstruction was not reviving Iraqi infrastructure came in a December 2004 report issued by the Post-Conflict Reconstruction Project of the Center for Strategic and International Studies. The report enumerated ways the impact of U.S. efforts in Iraq had been stunted. Only $27 \%$ of funding committed was actually spent on reconstruction, per se. The rest was siphoned off, with $30 \%$ spent on security, $12 \%$ on insurance and international salaries, $10 \%$ on overhead, and $6 \%$ on profits. An additional 15\% was lost to a standing line item in Iraqi work-fraud, corruption, and mismanagement. (Barton and Crocker, 2004) Then, in a head-spinning strategy shift, the focus moved to security and oil production as the State Department took over from the CPA. Work on water, sewage, and electricity was considered "too slow to have an immediate impact" and so spending in these areas was deliberately cut in half. (Tarnoff, 2009)

During 2005, several events occurred that would define Iraq's political system: three elections (two for a national assembly and one a referendum on the constitution), the drafting of the constitution itself, and the process of forming indigenous national and provincial governments based on election results. These were the first genuinely free elections in Iraq's modern history, but they also solidified trends already under way: fragmentation of the state along ethnic and sectarian lines, a weak central 
government, and a deeply divided political elite. The first elections were accomplished relatively smoothly-despite a number of irregularities and charges of fraud, the results were ultimately accepted. There was no meaningful ticket comprising Sunnis, however, which was a serious blow to the whole election outcome and clearly affected the results. The Sunnis learned their lesson quickly, but not before a pattern was set for the elections that followed. The result indicated the new government would continue to be led by the exile opposition parties and their leaders, with a significant shift to the more religiously-oriented Shia parties and the Kurds. The same parties that dominated the national level also swept the local elections. Overall, the provincial elections led to complex power struggles in many areas, including Baghdad, where the power vacuums soon allowed sectarian and ethnic conflict to spiral out of control. Shia families were increasingly driven out of Sunni-dominated neighborhoods by threats and assassinations. Shia militias responded in-kind with their own killings. Ordinary civilians living in this atmosphere essentially made the choice to either affiliate with a sectarian militia for protection or leave and join their respective community elsewhere. Many left the country. A substantial outflow of refugees and internally displaced persons resulted, ultimately measuring in the millions. Meanwhile, sectarian propaganda increased and sectarian banners marked off distinct Shia and Sunni areas. (Marr: 287-89, 301-02)

Splits within coalitions made governance difficult. The new government was only a temporary caregiver, charged with drafting a new constitution and getting it ratified by the National Assembly. Nonetheless, the two winning coalitions expected to gain a disproportionate share of power and resources in the new cabinet. The bargaining proved long and laborious, leaving Baghdad without a legitimate government for four months. Once completed, the cabinet was huge and unwieldly, consisting of 83 ministers. It proved largely dysfunctional, with each party using its ministries to reward supporters and relatives, often through corruption, nepotism, and patronage. After months of debate, the National Assembly was no closer to finalizing a draft constitution than they were in 2004. Under U.S. 
pressure, Sunni delegates were added as full voting members and negotiations became extremely contentious. The Kurds worked to weaken the authority of the central government on issues of tax, healthcare, and education. A proposal to make shari'a the basis of Iraqi law failed, but Islamists succeeded in defining the basis of the state and society as "the family" rather than "citizens". On August 8, 2005, Zalmay Khalilzad ${ }^{146}$, now the U.S. Ambassador in Iraq, convened a close-door meeting to hash out the remaining issues. Iraq was defined as a member of the Arab League, and the issue of deBaathification was raised again. (It had been stopped under Interim PM Allawi, but Chalabi instigated it again following the first election.) There was near-total unanimity, however, on the democratic basis of the government and the issue of strong human rights. (Id: 291-297)

The same month, a poll was conducted asking Iraqis how often they had safe, clean water. $72 \%$ responded "never". By late 2005, the number of people served by sewers dropped from a prewar 6.2 million to 4.5 million. Water treatment capacity decreased in the same period from 3 million cubic meters per day to 1.1 million cubic meters. (Brookings Institute, 2006: Iraq Index)

As campaign rhetoric increased, a wave of assassinations and armed attacks took place in Baghdad and other cities, a number of them on Sunni politicians. On October 19, 2005, the trial of Saddam Hussein began, adding to the tension. To meet this rising crisis and to maintain security during the election, U.S. troops were increased to an all-time high of 160,000. In the end, the December 2005 elections reinforced Iraq's growing ethnic and sectarian divide, as well as the previous difficulties in forming a government. Long delays in forming a cabinet and indecisions regarding the distribution of power contributed to sectarian tension. Sunni fears escalated when the Shia captured most of the security apparatus, including the Ministry of the Interior. The Shia also had their fears, having just gained

\footnotetext{
${ }^{146}$ As discussed previously, Khalilzad was in Baghdad in 2003 as an advisor appointed by President Bush, but he was removed from that post at Bremer's insistence.
} 
power for the first time in Iraq's modern history. Their anxiety over Sunni extremists, including al Qaeda in Iraq (AQI) was all-too justified. (Marr: 296-300)

The elections of 2005 placed powerful factions with armed militias at the head of ministries, who turned them into their personal fiefdoms, positioning themselves as the new Iraqi oligarchy (Bridoux: 108). Presiding over this delicate balance was a relatively inexperienced man, newly elected Prime Minister Nuri al-Maliki. Initially secretive and reportedly over-reliant on a small, inner circle of advisors, he would soon prove a master at the art of political maneuver. The new Maliki administration was full of members from the winning parties in the election. Allawi was totally missing, as was Chalabi. The first permanent post-2003 administration continued the dramatic decline in power of the secular, non-sectarian parties. (Marr: 299)

At the start of 2006, Iraq still had a large population of impoverished citizens, a lack of basic services, and few employment opportunities for a growing youth cohort. The money invested in improving living standards was insufficient, but the main problem in the economy more a lack of human resources than poor infrastructure. Officially, unemployment was reported at $15 \%$, but unofficially it was at least $30 \%$. Some estimates of under-employment put it as high as $60 \%$. Most jobs were in the military, security-related services, and government. $31 \%$ of the labor force was working for the public sector, only $9 \%$ less than Saddam's era.

What Iraq truly needed was educated and honest technocrats. Corruption and government inefficiency made it difficult to open up the economy to the private sector. There was a complete lack of budget preparation, allowing officials to under-specify and over-price equipment so they could skim money. Without local input, the Baghdad-based Ministry of Municipalities developed the budgets for all regional areas. Many municipal directors never attended coordination sessions, in spite of a multi-year $\$ 250$ million contract held by USAID to hold good-government classes for these same Iraqis. (Van Buren: 58) 
Nearly three years after the fall of Saddam, most colleges and schools remained closed, largely due to the reactivation of de-Baathification. Since all teachers, college professors, and even daycare workers had been required to join the Baath party, they were removed from their jobs by the CPA in 2003. For the few permitted to work, the violence kept most of the students away. Following what was intended to be the liberation of their country, these educators lost their profession and livelihood, had their lives endangered if they attempted to work for the occupation, and typically received only meager, short-term payouts from the U.S. that did not improve their prospects. (Id: 245-46)

In March 2006, the U.S. implemented the Iraq First Program as an attempt to provide more jobs to Iraqis. The program was intended to remove barriers preventing Iraqi businesses from competing against international companies for U.S. government contracts. (Bridoux: 120) But contractors often distorted local labor markets. The wages paid for trash pick-up by USAID's Community Stabilization Program were higher than the averages for skilled laborers. It was far more lucrative for Iraqis to be overpaid by the United States to pick up trash than it was to run a small business or fix broken machinery. (Van Buren: 60)

The Army's new counter-insurgency manual (largely directed by General Petraeus) was published at the end of 2006. It was a devastating critique of the conduct of the Iraq war. The new manual read, “Don't waste time and money attempting to build a local replica of the U.S. military. Have local forces mirror the enemy." (FM3-24: Counter-Insurgency, 2006) David Kilcullen, an Australian counterinsurgency expert and the man Petraeus asked to be his advisor, stated, "Give the people justice and honor. [Americans] talk about democracy and human rights. The Iraqis talk about justice and honor." His recommendations were almost the exact opposite of how most U.S. forces had operated during the first years of the war. Kilcullen admonished commanders to show Iraqis respect, but to also hold their counterparts accountable. When U.S. patrols rolled through Iraqi checkpoints, despite being 
ordered to stop, Kilcullen argued they lost the support of every Iraqi manning that station. (Ricks, 2009: 141-42)

By the end of 2006, Iraq was collapsing. The occupation and ambitious nation-building project, begun with more optimism than realism, had unraveled. Iraqi society was fragmenting along ethnic and sectarian lines. (Marr: 302-03) Facing failure, the U.S. administration unveiled the New Way Forward in early 2007. The main elements of the program included increasing American force levels by more than 20,000 troops (the so-called "Surge"), strengthening Iraqi military and police forces, implementing infrastructure reconstruction and economic programs aimed at giving every Iraqi citizen a stake in the country's economy, and organizing democratic elections and reviewing laws contributing to ethnic and religious tensions in Iraq-essentially, resolving conflicts over de-Baathification and oil revenues. (Bush, 2007; NSC, 2007: 7-9) Through provincial reconstruction teams, or PRTs, the New Way Forward favored smaller reconstruction projects showing fast benefits to the population. (Bridoux: 124-25)

This new approach came with significant risks, including getting rid of extremists by working with them and cutting deals with tribal leaders and other insurgent organizations. This angered the American public, but it was time to take the heat and make a choice. In the following months, U.S. commanders would sign up tens of thousands of former insurgents to become local militias, first called Concerned Local Citizens and, later, the Sons of Iraq. Converted militiamen were paid a monthly salary to man checkpoints in the areas where they used to commit violence. The program was basically a way to justify paying Sunni insurgents to stop killing Americans and Iraqi civilians, but it worked, and in many minds it was the key to the drop in violence accompanied by the troop surge of 2007-08. (Ricks: 157-58; Van Buren: 86-87)

It took time-sometimes two or three months-before the Americans and the Iraqis began to grow accustomed to each other. There were three steps of cooperation: first, the Iraqis would not work with the Americans; then, they would work covertly; and, finally, most would work openly. Under the 
new operating procedures, soldiers went into Iraqi homes to learn who lived in the neighborhood, to converse, drink tea, take photographs and census data, and learn about local concerns. As they began to know and see more, attacks on them and Iraqi civilians began to taper off. Many low-level fighters joined the insurgency for the money. By taking them away from al Qaeda and putting them on the American payroll, the huge economic advantage of the United States was finally brought to bear in Iraq. Extremists groups could not compete with the sheer volume of cash the U.S. was able to put in people's hands. Payments of $\$ 300 /$ month to 1,500 Iraqi security guards amounted to nearly a half million dollars each month. (Ricks: 176, 215)

Americans were impressed with the tactical skills of the former militiamen. Some of them were led by former Iraqi Army soldiers who found themselves unemployed after the disbanding. (Ricks: 20708) One of Petraeus' staff was especially impressed, believing them to be the most professional military organization he had seen in Iraq, by far: Lt Col Mark Fetter said insurgents were, in his opinion, "young men who have got to eat. There are so many we've detained and interrogated, and they did what they did for the money." Major General Rick Lynch, commander of a U.S. division just south of Baghdad, summarized: "They're honorable men, and they want to take care of their families." 147 (Ricks: 207-09) Starting in January 2007, which marked the beginning of the New Way Forward, reconstruction policies were altered and became more complementary. While the surge brought more boots on the ground, counter-insurgency tactics changed from 'find, fix, finish' to 'clear, hold, build'. In the wake of securing of a neighborhood, local expert teams of American advisors and Iraqis moved in quickly, protected the population, identified critical needs, started reconstruction projects, and improved governance in order to isolate insurgents. (Bridoux: 167-68) This embrace of the tribes and their ways could have happened earlier, but was discouraged by senior U.S. officials for ideological reasons. In

\footnotetext{
${ }^{147}$ It is the humble opinion of the author this was true for the vast majority of the $300+$ detainee cases she worked during her time in Iraq.
} 
2003 , commanders were hammered for working with the tribes; in 2007, the American effort finally stopped fighting Iraq's tribal structure and instead started to cooperate with it. Tribal justice was far from unsophisticated, after all-it was about mediation and conflict resolution, and had been operating for over 1,000 years. (Id: 219, 222-23)

In keeping with the new, more neutral stance of the U.S. military as the arbiter of events rather than an ally of one side, the National Police were also reined in. At times, they had been indistinguishable from a Shiite militia. Denying the National Police the ability to unilaterally operate in the neighborhoods greatly increased U.S. credibility. Commanders also learned to keep a wary eye on their internal allies, especially as they tried to capitalize on U.S. operations for their own ends. The fight was growing more complex. One day in May, four factions of the Jaish al-Mahdi militia (JAM) were fighting each other, so U.S. officials sent a message to JAM central: Get those guys out of the city. In response, JAM headquarters sent a team to Baghdad to sort out the problem. Because they were treated as an authority, the militia dealt with the problem. (Ricks: 177)

It was no coincidence that after the United States began cutting deals with the local militias, both the Sunni and the Shiite violent factions began fragmenting at a remarkable rate. A second component of the New Way Forward was national reconciliation through the enactment of key legislation. Laws were passed addressing Sunni concerns, including de-Baathification reform allowing lower-ranking members of the party to return to government jobs and the amnesty of certain detainees. ${ }^{148}$ There was still a scramble for power in the future of Iraq, with the Americans just trying to make sure there would be some Sunni entries in the race. (Bridoux: 124-26)

Progress was also due to ethnic cleansing in 2006 and 2007. Few neighborhoods were still mixed, and hence Sunnis and Shias tended to kill each other less. In addition, the indiscriminate killings performed by al Qaeda led a sizeable contingent of Sunni insurgents to side with the U.S. and Iraqi

148 The implementation of these reforms eventually stalled, however. 
Security Forces in chasing down insurgents and terrorists. By 2007, these battles had turned neighborhoods into wastelands. In this atmosphere, trust between ordinary citizens who had lived and worked together for years was totally shattered. (Marr: 301-02) U.S. combat deaths climbed inexorably: 70 in February, 71 in March, 96 in April, and 120 in May, which became the deadliest month for U.S. troops in two years. According to statistics from U.S. military databases, there were 6,037 "significant acts" of violence in Iraq during May 2007, the highest recorded total since November 2004.

The additional casualties were expected as the price for moving from big, safe bases to smaller outposts among the population, but they came at the same time as a series of horrific killings of Iraqi civilians. In February, a ton of explosives detonated in a market in a predominantly Shiite area of Baghdad, killing at least 125 and wounding 300 more. It was the single deadliest terrorist bombing ever in the capital. The insurgents also began introducing worrisome new tactics, including chemical weapons and use of children as shields or diversions. By this point in the war, U.S. soldiers were fond of saying all the stupid insurgents were dead. Americans had come and gone, but many of their enemies had fought nonstop in Iraq for several years. Those who survived were fit and adaptive. (Ricks: 179-80)

The results of a March 2007 poll indicated the discontent felt by Iraqis regarding the progress of the reconstruction. Compared to November 2005, when $71 \%$ of Iraqis declared their lives were going well, in March 2007 only 39\% made the same statement. 74\% declared their neighborhoods were not safe. (ABC News/USA Today/BBC/ARD Poll 2007:1) More alarming, the number of Iraqis rejecting the U.S. presence had grown considerably since the beginning of the occupation, with Iraqis tending to blame the U.S. for all their problems. 51\% deemed attacks on the U.S. or coalition forces acceptable and $78 \%$ rejected U.S. presence in the country. Regarding the effectiveness of the reconstruction, $67 \%$ of Iraqis qualified it as ineffective in their area, with the worst ratings coming from areas experiencing high levels of violence. (Bridoux: 121) A 2007 Iraq mental health survey estimated almost one in five Iraqis 
had some mental illness, and four out of ten school children under 16 had a mental disorder. (Marr:

2007 saw a return to some normality in economic development in Baghdad and the south. One of the chief accomplishments was the utilization of oil resources. But despite having the world's fourthlargest reserves, Iraq was only the twelfth-largest producer. For most of the post-Saddam period, production hovered between 2 and 2.4 million barrels per day, not exceeding the levels in Saddam's last years. Various international institutions estimated it would take an additional \$1 billion annually just to sustain production at those levels. Actual reconstruction would cost an additional \$1 billion, even before exploration for additional sources. Acquisition of necessary skills, technology, and spare parts was also essential, and the infrastructure constraints were daunting. There was need for water or gas injection to operate the wells, greater supplies of electrical power, and major upgrades to refining and export facilities, such as pipelines (which were also popular targets for insurgents). (Marr: 354-55)

The greatest need in Iraq's economy was for development of the country's human resources. Iraq had been losing its educated middle class for years, but the huge outpouring of doctors, professors, lawyers, engineers, scientists, writers, artists, and bureaucrats after 2006 crippled the educated class. Extremists personally targeted the remaining educated citizens. 431 Iraqi academics were assassinated, the vast majority of them PhDs. 247 media professionals were murdered by mid-2007, and the Iraqi Lawyers Association claimed 210 lawyers and judges were killed. The Iraqi Red Crescent believed about $50 \%$ of Iraq's doctors and $70 \%$ of medical specialists left in the exodus.

Unfortunately, replenishing Iraq's skills would take decades at best, and initiatives yielded slow progress. The budget for education increased from $3 \%$ of the total in 2006 to $5 \%$ in 2008 , and the construction of new schools also increased, but the effort was more "brick and mortar" than quality. Concern for better education was reflected in a program offering 10,000 government scholarships to study abroad each year for five years, but it would take time for this program to produce qualified 
faculty; meanwhile, schools and universities continued to expand. Medical schools, for example, increased from seven in 2003 to 20 by the end of 2007. In the midst of a brain drain of doctors, this raised serious questions about the teaching staff, and some of these schools did not have medical libraries or proper labs. (Ricks: 363-64, 370)

Not much progress was made in the productive sectors, either. Some development took place in industries such as construction materials, food processing, and production of everyday goods, but there was little talk of growth in local industries, much less revival of larger ones like steel, aluminum, petrochemicals, and high-tech. One reason for this was the lack of ability to compete, as the market was flooded with manufactured imports. Another was the shortage of power generation. One authority concluded the new Iraq had failed to produce a private sector and its economy was still functioning as it always had-with the government existing on oil revenues and putting its citizens on the payroll. (Marr: 364-65)

In addition to neglect, the country's agriculture sector faced a serious, long-term problem (not of Iraq's making): a greatly reduced water supply. The country depended on irrigation from the Tigris and Euphrates, but in recent decades, Turkey had placed dams on the headwaters of both rivers, and Syria also did so on the Euphrates. Facing an already drastically reduced flow, Iraq estimated its water needs would grow by $50 \%$ over the next decade as increased aridity created creeping desertification and an increase in sandstorms in the once-arable south. The lack of water also affected hydro-electric power. Iraq had almost 75,000 miles of canals, which would take years to clean and restore. Modern techniques needed to be introduced immediately to save and manage water resources. (Id: 365$)$

In early 2008 , the situation slowly improved as refugees and internally displaced persons trickled back to their quarters and commerce revived. Nonetheless, the new realities of Baghdad, even after some of the walls built by the surge were dismantled, was a far more divided city. Separate neighborhoods of like religious backgrounds dominated life and business. The population shift also had a 
marked impact on social structure. In general, Iraq's upper and middle classes had left, leaving the poor and relatively unskilled behind. Some analysts indicated the "sectarian strife" might also be a class struggle. The epitome of this class difference was Sadr City, filled with earlier immigrants from the Shia south who only partially integrated into urban life and still followed a more rural and traditional lifestyle. The new, upscale areas of Baghdad had always feared an onslaught from this area in times of crisis, and this is effectively what happened during the violence. The shift in class structure also helps explain the ease the militias, like the Mahdi Army, had in recruiting new members, as well as the resurgence of more traditional practices, religious rituals, and social conservatism. These changes also shifted the population further towards youth, rather than the experienced older generation. Both trends affected political and intellectual life, and threw Iraqi society to family and religion as social mechanisms for survival. (Id: 368-69)

The Americans started 2008 antagonized by what they saw as Prime Minister Maliki's footdragging on bringing former insurgents onto the Iraqi payroll. At this time, there were 103,000 Sons of Iraq, but plans to absorb only 20,000 of them into the police and army. It was not clear what would ultimately happen to the rest, especially if the Sunni community continued to feel estranged from the government. An Army officer in Baghdad reported that after his unit sent applications for Sunnis to join the police force, they were returned because they were filled out with a non-prescribed color of ink. The longer the new government stalled, the greater the danger tens of thousands of tough, armed Iraqis would stray.

There was always an undercurrent of distrust when dealing with Iraqi officials. Top officials did not only not do the right thing, they did not seem to want to do their jobs at all. Maliki's supporters argued it was not clear anyone else could do better, and there was fear pushing him out could return the country to the situation it faced in 2006, when it took months to form a government and Baghdad drifted into municipal civil war. The New Way Forward was starting to resemble so many other failed 
plans in Iraq: not a bad idea in the short term, but no clear path for the future. Then, on Easter Sunday, 2008 , powerful rockets began to rain down on the Green Zone. From that day through mid-May, more than 1,000 rockets would be fired at the Zone ${ }^{149}$, mainly from Sadr City, making a mockery of the truce Sadr was supposedly following. By the U.S. military's count, the attacks killed or wounded 269 people. These attacks were an attempt to prevent the Iraqi Army from launching its first major offensive since 2003: an effort to drive Sadr's Mahdi army from the southern city of Basra. The Army was eventually successful, but U.S. and Iraqi government operations in Baghdad slowed to crawl, or halted completely, for several weeks. (Ricks: 263-65, 279) $)^{150}$

During the 2007-08 troop surge, 1,124 American soldiers were killed and 7,710 wounded. About another 24,000 Iraqi soldiers, police officers, and civilians were killed. The Sunni fighters entered into a ceasefire, not a surrender, keeping their weapons, organizations, and-in some cases-even their areas of operation as they merged into the Sons of Iraq. As the surge ended in mid-2008, with the last of the five additional American combat brigades heading home, Baghdad felt distinctly better. Kebab stands and coffee shops had reopened across the city, and many ordinary Iraqis felt safe enough to venture out of their homes at night, mostly because stores were remaining open to evening shoppers. ${ }^{151}$ Even as Iraq's factions remained murderously divided, violence was at its lowest level of the entire war, and some 39,000 displaced families safely returned to Baghdad. After the surge, Americans tried to turn over security functions to Iraqi forces, but some went back to the violent opposition. American units were dispatched to support Iraqi forces fighting these enemies-turned-allied-turned-enemies again. Despite

\footnotetext{
${ }^{149}$ The author was assigned to the Green Zone during this entire period. A few of her colleagues received minor wounds and two of her staff had their living quarters destroyed, but thankfully no one from her office was seriously hurt. Two civilian employees working for the Embassy were killed, however, when they remained in their quarters during an attack rather than going to a bunker.

${ }^{150}$ This included basic services like sanitation, cooking, and cleaning. At one point, bags of trash were piled to shoulder-height along the hallways of the Embassy, and toilets could not be flushed because the sewage system was backed up.

151 Other than the Sadr City siege, attacks in Baghdad were rare during the author's deployment there. Before and after the siege, trips to local markets and restaurants-if conducted in armored vehicles-were permitted.
} 
such incidents, security did not deteriorate as quickly as expected, and instead the confrontations between Sunni insurgents and Iraqi forces tapered off. Then, in late June, when American troops closed outposts in the cities and moved back to big bases, there was a spate of bombings and other violence.

(Id: 294, 303, 328-29)

By July 2008, U.S. Army officers were referring to the ineffectiveness and corruption of the Iraqi government and its ministries as "the stuff of legend". The government was failing to take rational steps toward improving electrical infrastructure or oil exploration, production, and exporting. Sunni reconciliation was at a standstill. Political violence and intimidation were rampant. (Reese, 2007) The majority of Iraqi army divisions were under the patronage of political parties, as were forces from the Ministry of the Interior. This political meddling was causing a divisive situation within those forces, one likely to fracture the country. (al-Jabouri, 2007) U.S. efforts to create a new Iraqi military had never gone particularly well. Part of the reason grew out of the political obstacles facing Iraq: a member of a militia might not have proper equipment or be well-trained, but he knew what he was fighting for. By contrast, a member of the Iraqi Army, despite having reliable American gear, did not know if the government for which he fought would even exist in a year. Nonetheless, the size of Iraqi security forces increased from 400,000 in June 2007 to 560,000 a year later, actually becoming larger than the active-duty U.S. Army.

(Ricks: 197, 199)

By mid-2008, despite U.S. efforts, Iraqi unemployment was $17.6 \%$, with underemployment at 38.8\% (DoD 2008a: 12). Electricity demand continued to exceed supply ${ }^{152}$, and access to clean water ${ }^{153}$ and sanitation was the lowest in the region. Road, rail, and air transport had improved, but not enough. Poor control of the borders was listed as the top concern for those doing business in Iraq, because this lack of security led to smuggling, theft, and even piracy. Iraq's Ministry of Human Rights estimates

\footnotetext{
${ }^{152}$ Iraq could provide its citizens with only about 14.1 hours of electricity per day.

${ }^{153}$ World Bank figures indicate potable water was available to about $70 \%$ of Baghdad, with numbers as low as $48 \%$ in some rural areas.
} 
86,690 people were killed in the four-year period between $2004-2008$, with another 147,190 wounded. Thousands more were listed as missing or buried in the chaos. The UN High Commissioner for Refugees put the number of Iraqi refugees living in neighboring countries in 2008 at 1.7 to 2.3 million. According to the International Organization for Migration, the number of people displaced internally was still 1.6 million. (Marr: 362-65, 367)

\section{A Note On Economic Costs}

There is the matter of treasure as well as blood. It would be remiss to not discuss the economic impacts of the occupations, as well as how the expenditures played into the success of the effort, lest anyone believe the failures in Iraq were due to a lack of funding.

The dollar costs of the Iraq war were far greater than expected. A detailed and objective estimate of Iraq war costs by two economists at Harvard noted that, before the war, Deputy Secretary of Defense Paul Wolfowitz claimed resurgent oil production would finance Iraq's reconstruction. Secretary Rumsfeld's office and the Office of Management and Budget estimated total war costs would range from $\$ 50$ to $\$ 60$ billion. In fact, the overall war ended up costing $\$ 1$ billion per week. (Van Buren: 251) This early estimate included neither indirect costs nor anticipated the possibility of a post-war insurgency. By 2008, when factoring in indirect war expenses such as additional Veterans Administration costs, veterans' health expenditures and disability payments, demobilization costs, replacement costs of military hardware lost or rapidly depreciated, and last (but hardly not least) interest payments on the additional debt incurred by financing the war entirely on borrowed money, the Harvard study determined the true cost of the war was $\$ 1.026$ to $\$ 2.239$ trillion. Even if the lower estimate is correct, it is still another gross miscalculation about the cost and consequences of the decision to invade Iraq.

(Record, 2007: 98) 
Unlike the cases of Germany and Japan, there was no massive humanitarian crisis requiring aid in Iraq. The total amount of U.S. assistance allocated for Iraq in the first three years of its occupation was comparable to the total amount provided to Germany and double the amount given to Japan for the seven years following World War II. The costs fell under different categories, but one area in which a rough approximation is possible is funding for reconstruction and improvement of critical economic infrastructure. Aid allocations for Iraq reached $\$ 117$ billion by 2008 . Of this, about $40 \%$ ( $\$ 46.8$ billion) was for the repair and improvement of critical infrastructure. In contrast, the total assistance provided to Germany from 1946 to 1952 was $\$ 29.3$ billion (in 2008 dollars), while Japan received only $\$ 15.2$ billion (in 2008 dollars) during the same time period. ${ }^{154}$ (Serafino: 1, 3)

U.S. funding provided specifically for economic infrastructure in Iraq appears to be greater than the proportion provided for the same purposes in Germany and Japan. The United States' primary objective in the post-World War II occupations was demilitarization, followed by disarmament and decentralization in Japan and denazification and deindustrialization in Germany. Together, the infrastructure reconstruction assistance and the social, economic, and political development aid-which is more characteristic of current U.S. assistance around the world-make up nearly two-thirds of total Iraq funding. The remaining funds ( $\$ 44.5$ billion) were targeted at bolstering Iraq's security. ${ }^{155}$ Most of this money was meant to provide training and equipment to the various security forces, including the Iraqi National Police and the Iraqi Army, as well as facilities for security personnel and law enforcement officials. (Id: 2, 6-7)

One reason for these cost discrepancies could be the aid for economic reconstruction in Germany and Japan consisted of financing through loans and grants in order to enable those countries to carry out their own recovery. In Iraq, the United States provided not only the material assistance, but

\footnotetext{
${ }^{154}$ In 1952 dollars, these amounts were $\$ 4.3$ billion and $\$ 2.2$ billion, respectively.

${ }^{155}$ For comparison, the entire national defense budget for the United States in 2008 was $\$ 647$ billion.
} 
also paid for the necessary labor, usually through third-party contractors. The reason for this is unclear, since-even in the middle of the sectarian violence and after two decades of decay in its production infrastructure-Iraq was producing 2.5 million barrels of oil per day, giving it an annual income of \$17 billion. With proven reserves of 112 billion barrels-more than $10 \%$ of the world's total, second only to Saudi Arabia-its ability to finance its own recovery should have been clear. In fact, industry experts believe Iraq's actual reserves could be twice the current estimate. (Diamond, 2005: 334)

By 1952, Germany (with a population of 69.8 million) and Japan (with 73 million) had recovered to pre-war GDP levels (Maddison, 2003). For Iraq, that timeline came and went in 2010. The Iraq reconstruction never met its goals on the reconstruction front, and the number of project completions in the key areas of water and health fell far short of hopes (Bowen: ii-iii). There were almost too many failed projects to document, though SIGIR tried. The "legacy of waste" included a $\$ 40$ million prison that never opened, a \$104 million failed sewer system, a \$171 million hospital Laura Bush “opened” in 2004 but that never saw a single patient, and more, totaling \$5 billion. (Van Buren: 214) 


\section{CHAPTER 7 \\ FINDINGS AND RECOMMENDATIONS}

The American occupations of Germany and Japan lasted more than six years and involved deployment of more than one million Americans. Neither occupation started with this level of effort in mind, however - that came later. In part, this commitment was a consequence of the horror of World War II, and the deep desire by the Allies to uproot regimes whose hyper-aggressive behavior caused destruction on such a massive scale. Despite years of planning, the United States still under-estimated the amount of time required for the complex task of rebuilding infrastructure, vetting officials, restructuring institutions, and transforming citizens' relationships with their government. Occupation officials soon realized while they could physically secure the environment more or less on their own, they needed indigenous institutions to begin the process of deeper social and political reforms essential to the eventual down-sizing of the occupation. This late realization is a constant in the calculus of postwar planning throughout U.S. history, and would happen again in Iraq.

From 1975 to 2001, the United States fundamentally re-shaped its doctrine of military engagement without similarly reforming its commitment and capacity to stabilize and transform postconflict environments. Such a dissonance between an over-developed ability to wage and win war and an anemic facility for winning peace did not bode well for a preemptive war and ambitions to re-make an authoritative regime into a functioning democracy within twelve months. By the end of 2008, Iraq was still not supporting U.S. interests in the Middle East; in fact, its status was the root of many diplomatic conflicts in the region, and access to oil promised to be heavily controlled by the provinces, rather than by the central government.

The U.S.-led reconstruction project in Iraq was a failure in the exercise of foreign policy. On top of the astronomical amount of money spent by Washington in the war on terror, America lost more than it gained in the venture. With more than 4,000 killed and $30,000+$ wounded, the U.S. paid a heavy price 
for its attempt. Written in 2005, after a review of the classified record, a RAND Corporation report noted "post-conflict stabilization and reconstruction were addressed only very generally, largely because the prevailing view was the task would not be difficult". Planners at the Pentagon relied heavily on intelligence and advice provided by the Iraqi exiles who promised the Americans would be welcomed by the population, stability and security would be maintained, and a working infrastructure would be left in place. (Dreyfuss, 2005) Consequently, planning did not focus on potential turmoil following the fall of the Baath regime. No tactics were designed to deal with control of key structures such as ministries and essential service facilities, with the notable exception of the Ministry of Oil. U.S. forces were handicapped from the start because they lacked the structures needed to maintain stability and the troops to control the country. (Bridoux, 2011: 91-92) Thus, the United States invaded without an effective plan to secure the peace.

This research endeavors to address the question of whether lack of planning for post-conflict situations doom reconstruction efforts, or whether changes in the implementation of policies and procedures could have saved U.S. efforts in Iraq. By comparing approaches in Iraq to those in Germany and Japan, the author is able to contrast the most successful U.S. occupations with the arguably least successful, and determine the results of varying approaches across the case studies. Extensive details regarding each factor examined were laid out in previous chapters. This chapter aims to briefly summarize those details to illustrate exactly what the occupiers faced in terms of difficulties, lack of resources, and other obstacles, and determine whether Iraq was truly the more challenging occupation from the start. Based on the findings, implications for future occupation efforts, as well as research, will be presented. 


\section{Contextual \& Hybrid Factors}

Most scholars have focused on ideas like consistency, legitimacy, and cohesion to explain why the German and Japanese occupations were successful and Iraq was a failure. They rely on inherent characteristics within the culture or situations outside the occupier's control to justify the outcome-in other words, the results are almost pre-determined. Given the goal of most reconstruction efforts, this seems like too easy an excuse. Rather, if these factors are not weighing in the occupations favor, then changes in the Instigated factors proffered in this work should be considered at great length. But, even in the cases presented here, the contextual and hybrid factors were not as favorable towards Germany and Japan and as against Iraq as it may seem. The tables below provides the commonly-held beliefs of scholars, contrasted with the facts asserted in this work.

Table 1: Contextual Factors

\begin{tabular}{|c|c|c|c|}
\hline Factor & Germany & Japan & Iraq \\
\hline $\begin{array}{l}\text { Historical } \\
\text { Precedent }\end{array}$ & $\begin{array}{l}\text { Bellin, Dower, Maier and } \\
\text { Bridoux each assert this was } \\
\text { a strong positive factor. } \\
\text { However, experience with } \\
\text { true democracy was scarce } \\
\text { during the Weimer Republic } \\
\text { and factual accounts by } \\
\text { Zeimke explicitly state the } \\
\text { complete absence of political } \\
\text { parties in } 1945 \text {. }\end{array}$ & $\begin{array}{l}\text { Bellin, Dower, Maier and } \\
\text { Bridoux all assert this was a } \\
\text { strong positive factor, but } \\
\text { the Taisho Democracy } \\
\text { lacked significant } \\
\text { protections for speech, } \\
\text { assembly, and protest. }\end{array}$ & $\begin{array}{l}\text { Democratic constitution in } \\
1923, \text { followed by four } \\
\text { decades of democratic rule. } \\
86 \% \text { of citizens preferred a } \\
\text { democracy in } 2003 \text {, and } \\
\text { several parties were ready } \\
\text { to participate. }\end{array}$ \\
\hline Cohesion & $\begin{array}{l}\text { Bellin, Dower, Maier, } \\
\text { Bridoux, Jennings, Maulucci } \\
\text { and Dobbins each assert this } \\
\text { was a strong positive factor. } \\
\text { However, millions of } \\
\text { refugees, displaced persons, } \\
\text { former concentration camp } \\
\text { prisoners, and others who } \\
\text { had spent years ostracized by } \\
\text { the Nazis were now living } \\
\text { within society amongst those } \\
\text { who oppressed them. }\end{array}$ & $\begin{array}{l}\text { Bellin, Dower, Maier, } \\
\text { Bridoux, Jennings, Dobbins, } \\
\text { Junichiro and Beasley each } \\
\text { assert this was a strong } \\
\text { positive factor. However, } \\
\text { caste systems resulting in } \\
\text { severe class discrimination, } \\
\text { as well as ethnic minorities } \\
\text { hoping for sovereignty } \\
\text { were challenges to } \\
\text { overcome. }\end{array}$ & $\begin{array}{l}97 \% \text { of the country shared } \\
\text { the same religion, and } 80 \% \\
\text { shared an ethnic } \\
\text { background. The Shia } \\
\text { majority was a substantial } \\
\text { part of the Army and had } \\
\text { fought for the country in } \\
\text { three previous wars. } \\
\text { Differences were largely } \\
\text { political, and community } \\
\text { ties were strong, based on } \\
\text { tribal affiliations. Only Al } \\
\text { Khajafi argues strong ties to }\end{array}$ \\
\hline
\end{tabular}




\begin{tabular}{|c|c|c|c|}
\hline & & & $\begin{array}{l}\text { the state were a positive } \\
\text { factor. }\end{array}$ \\
\hline Exhaustion & $\begin{array}{l}\text { Bellin, Dower, Maier, } \\
\text { Bridoux, Killick, Barnett, and } \\
\text { the U.S. Bombing Survey } \\
\text { each assert this was a strong } \\
\text { positive factor. However, the } \\
\text { Army continued to fight and } \\
\text { supplies were still plentiful. }\end{array}$ & $\begin{array}{l}\text { Bellin, Dower, Maier, } \\
\text { Bridoux, Dobbins, Maulucci } \\
\text { and the U.S. Bombing } \\
\text { Survey each assert this was } \\
\text { a strong positive factor. } \\
\text { However, the Army } \\
\text { continued to fight, } \\
\text { including the use of } \\
\text { kamikaze techniques. }\end{array}$ & $\begin{array}{l}\text { Iraq had suffered a decline } \\
\text { in living standards (similar to } \\
\text { Japan's) for a decade. Its } \\
\text { youth population had no } \\
\text { employment prospects and } \\
\text { the middle class was } \\
\text { decimated. Its Army was } \\
\text { defeated in less than three } \\
\text { weeks; it then simply went } \\
\text { home. }\end{array}$ \\
\hline $\begin{array}{l}\text { External } \\
\text { Enemies }\end{array}$ & $\begin{array}{l}\text { Bellin, Dower, Maier, } \\
\text { Mauluccie and Bridoux each } \\
\text { assert this was a strong } \\
\text { positive factor, due mostly to } \\
\text { the advent of the Cold War. }\end{array}$ & $\begin{array}{c}\text { Bellin, Dower, Maier, } \\
\text { Bridoux, Cohen, Maulucci } \\
\text { and McGrath each assert } \\
\text { this was a strong positive } \\
\text { factor, as there were no } \\
\text { challenges to the } \\
\text { occupation. }\end{array}$ & $\begin{array}{l}\text { Iraq did not have external } \\
\text { enemies as a nation; rather } \\
\text { the U.S. occupation } \\
\text { developed challenges to its } \\
\text { presence and authority } \\
\text { through inconsistent foreign } \\
\text { policy choices. }\end{array}$ \\
\hline
\end{tabular}

Table 2: Hybrid Factors

\begin{tabular}{|c|c|c|c|}
\hline Factor & Germany & Japan & Iraq \\
\hline $\begin{array}{c}\text { Economic } \\
\text { Development }\end{array}$ & $\begin{array}{l}\text { Bellin, Dower, Maier and } \\
\text { Bridoux each assert this } \\
\text { was a strong positive } \\
\text { factor. In fact, } 95 \% \text { of } \\
\text { infrastructure was } \\
\text { destroyed or inoperable; } \\
\text { the remaining } 5 \% \text { was at } \\
\text { only } 15 \% \text { of capacity. }\end{array}$ & $\begin{array}{l}\text { Bellin, Dower, Maier and } \\
\text { Bridoux each assert this } \\
\text { was a strong positive } \\
\text { factor. But Japan could not } \\
\text { feed itself, and its } \\
\text { production capabilities } \\
\text { were only } 10 \% \text { of the U.S. }\end{array}$ & $\begin{array}{l}\text { Ricks and Banerjee note Iraq } \\
\text { was not a struggling Third } \\
\text { World nation; it has the } \\
\text { second-largest oil reserves in } \\
\text { the world and (at the time of } \\
\text { invasion) a functioning pipeline } \\
\text { system and power grid. }\end{array}$ \\
\hline Legitimacy & $\begin{array}{l}\text { Bellin, Dower, Maier, } \\
\text { Maulucci and Bridoux each } \\
\text { assert this was a strong } \\
\text { positive factor. In truth, } \\
\text { Germany's civilian } \\
\text { government never } \\
\text { surrendered. }\end{array}$ & $\begin{array}{l}\text { Bellin, Dower, Maier and } \\
\text { Bridoux each assert this } \\
\text { was a strong positive } \\
\text { factor. This was largely due } \\
\text { to the occupation's choice } \\
\text { to leave the emperor and } \\
\text { much of the bureaucracy } \\
\text { intact to encourage } \\
\text { cooperation by the people. }\end{array}$ & $\begin{array}{l}\text { Occupation was recognized by } \\
\text { the UN Security Council, and no } \\
\text { nation came to Iraq's defense. } \\
\text { Given the extreme ease of } \\
\text { which the U.S. reached } \\
\text { Baghdad, it seems obvious } \\
\text { even if U.S. forces had moved } \\
\text { slower, Iraqi forces would still } \\
\text { not have been able to build a } \\
\text { stronger defense. Lack of } \\
\text { physical occupation was a } \\
\text { choice, not a challenge. }\end{array}$ \\
\hline $\begin{array}{l}\text { Consistency } \\
\text { of Authority }\end{array}$ & $\begin{array}{l}\text { Bellin, Dower, Maier, } \\
\text { Barnett, Keifer, Zeimke and } \\
\text { Bridoux each assert this } \\
\text { was a strong positive } \\
\text { factor. Military } \\
\text { government troops } \\
\text { entered behind combat }\end{array}$ & $\begin{array}{l}\text { Bellin, Dower, Maier, } \\
\text { Dobbins, the U.S. Bombing } \\
\text { Survey, Schonberger and } \\
\text { Bridoux each assert this } \\
\text { was a strong positive } \\
\text { factor. MacArthur did not } \\
\text { force democratization if it }\end{array}$ & $\begin{array}{l}\text { Little to no consideration was } \\
\text { given to the power vacuum } \\
\text { following regime fall. Mixed } \\
\text { messaging resulted in } \\
\text { insistence occupation was a } \\
\text { short-term situation, then a } \\
\text { complete reversal. No follow- }\end{array}$ \\
\hline
\end{tabular}




\begin{tabular}{|c|c|c|c|}
\hline & $\begin{array}{l}\text { units and secured every } \\
\text { town and village. }\end{array}$ & $\begin{array}{l}\text { risked stability and } \\
\text { security. }\end{array}$ & $\begin{array}{l}\text { on forces, and two different } \\
\text { authorities in less than one } \\
\text { month. }\end{array}$ \\
\hline Security & $\begin{array}{l}\text { Bellin, Dower, Maier, } \\
\text { Bridoux, Maulucci, } \\
\text { Jennings, Barnett, Fischer } \\
\text { and Zeimke each assert } \\
\text { this was a strong positive } \\
\text { factor. Martial law was } \\
\text { declared and German } \\
\text { troops were used, in } \\
\text { addition to sufficient } \\
\text { numbers of U.S. forces. }\end{array}$ & $\begin{array}{l}\text { Bellin, Dower, Maier, } \\
\text { Bridoux, Dobbins, and the } \\
\text { U.S. Bombing Survey each } \\
\text { assert this was a strong } \\
\text { positive factor. Weapons } \\
\text { caches were located and } \\
\text { destroyed quickly, with the } \\
\text { Japanese aiding the effort. }\end{array}$ & $\begin{array}{l}\text { Vast amounts of weapons were } \\
\text { left unguarded and later armed } \\
\text { insurgents. Borders were left } \\
\text { unsecure. Insufficient troop } \\
\text { levels led to military } \\
\text { installations being unsecured } \\
\text { and rampant looting } \\
\text { throughout the country, all } \\
\text { within the first few weeks. }\end{array}$ \\
\hline $\begin{array}{l}\text { Civil } \\
\text { Institutions }\end{array}$ & $\begin{array}{c}\text { Bellin, Dower, Maier, } \\
\text { Bridoux, Dobbins, Zeimke, } \\
\text { Barnett and Marrus each } \\
\text { assert this was a strong } \\
\text { positive factor. There was } \\
\text { an extensive bureaucratic } \\
\text { state, but also an } \\
\text { unparalleled humanitarian } \\
\text { crisis. Yet, schools were } \\
\text { operational within a month } \\
\text { and the press/media } \\
\text { within three. }\end{array}$ & $\begin{array}{l}\text { Bellin, Dower, Maier, } \\
\text { Bridoux and Dobbins each } \\
\text { assert this was a strong } \\
\text { positive factor. Mid-level } \\
\text { bureaucracy was left intact, } \\
\text { but there was a complete } \\
\text { overhaul of laws and } \\
\text { societal norms. U.S. } \\
\text { soldiers ensured the } \\
\text { Japanese followed new } \\
\text { procedures. }\end{array}$ & $\begin{array}{l}\text { CPA failed to work within } \\
\text { traditional informal power } \\
\text { structures. It relied on exiles, } \\
\text { rather than internal leaders, } \\
\text { despite well-established and } \\
\text { extensive administrative } \\
\text { structures within the Iraqi } \\
\text { state. Local councils were given } \\
\text { no money or authority. }\end{array}$ \\
\hline
\end{tabular}

As is easily seen from the few facts presented above, the Contextual Factors were not nearly as skewed towards German and Japan as the scholars listed have always asserted; rather, Iraq had strong indicators it could successfully transition to democracy, though these were often overlooked or misunderstood by more Western researchers. When it comes to the Hybrid Factors, German and Japan did enjoy the benefits of a more positive experience, but-as the brief facts within the table show-this was mostly due to decisions made by the occupier, not due to innate characteristics. A summary of the Instigated Factors examined in this work makes this point even more strongly.

Table 3: Instigated Factors

\begin{tabular}{|c|c|c|c|}
\hline Factor & Germany & Japan & Iraq \\
\hline $\begin{array}{c}\text { Operational } \\
\text { Planning }\end{array}$ & $\begin{array}{c}\text { Planning began in 1944; } \\
\text { scope of effort was } \\
\text { grossly under- }\end{array}$ & $\begin{array}{c}\text { Japan surrendered much } \\
\text { earlier than anticipated, } \\
\text { so invasion troops were }\end{array}$ & $\begin{array}{c}\text { Previous plans were } \\
\text { disregarded; most experts } \\
\text { agreed (even prior to }\end{array}$ \\
\hline
\end{tabular}




\begin{tabular}{|c|c|c|c|}
\hline & $\begin{array}{l}\text { estimated, BUT there } \\
\text { were sufficient troops } \\
\text { to alter the plans, as } \\
\text { necessary: } 1.6 \text { million at } \\
\text { the high end, and never } \\
\text { dropping below } \\
200,000 \text {. }\end{array}$ & $\begin{array}{l}\text { available for occupation } \\
\text { use: } 345,000 \text { during first } \\
\text { several months. }\end{array}$ & $\begin{array}{l}\text { invasion) the troop levels } \\
\text { were insufficient: } 160,000 \text { at } \\
\text { peak. Competing visions of } \\
\text { regime change led to } \\
\text { disagreements on handling of } \\
\text { post-combat phase. }\end{array}$ \\
\hline $\begin{array}{c}\text { Approach to Civil } \\
\text { Affairs }\end{array}$ & $\begin{array}{l}\text { Army wanted to } \\
\text { maintain control, so } \\
\text { ensured there were } \\
\text { sufficient troops. Mil } \\
\text { Gov't units served as a } \\
\text { "buffer" b/w } \\
\text { population and } \\
\text { government. }\end{array}$ & $\begin{array}{l}\text { Focus shifted to cultural } \\
\text { similarities, with Japanese } \\
\text { permitted to continue } \\
\text { running the country with } \\
\text { American oversight. }\end{array}$ & $\begin{array}{l}\text { No civil affairs training in DoD } \\
\text { in 2003; most occupations } \\
\text { since } 1945 \text { were run by the } \\
\text { State Dept. Poor training of } \\
\text { local forces, use of } \\
\text { contractors distorted labor } \\
\text { markets, failure to provide } \\
\text { basic services, overall } \\
\text { inability to follow basic } \\
\text { counter-insurgency } \\
\text { principles. }\end{array}$ \\
\hline Policy Decisions & $\begin{array}{l}\text { De-Nazification policy } \\
\text { was altered many } \\
\text { times, and eventually } \\
\text { turned over to the } \\
\text { Germans, who policed } \\
\text { themselves and } \\
\text { rehabilitated most } \\
\text { offenders. }\end{array}$ & $\begin{array}{l}\text { Army and Navy were } \\
\text { permitted to handle their } \\
\text { own deactivation. } \\
\text { Japanese worked with } \\
\text { U.S. forces to identify } \\
\text { militants. Local } \\
\text { communities voted on } \\
\text { reconstruction projects. } \\
\text { Economic purges } \\
\text { benefited most, and loss } \\
\text { of technocrats was } \\
\text { absorbed due to secure } \\
\text { environment. }\end{array}$ & $\begin{array}{c}\text { Military and civilian experts } \\
\text { specifically warned against } \\
\text { CPA Orders \#1 and \#2. Army, } \\
\text { police, and most civil } \\
\text { servants were permitted to } \\
\text { walk away-no martial law } \\
\text { was ever declared, nor was } \\
\text { an effort made to employ } \\
\text { Iraqis in reconstruction } \\
\text { projects. }\end{array}$ \\
\hline Constitution/Elections & $\begin{array}{l}\text { Local elections held } \\
\text { within } 10 \text { months, even } \\
\text { though some parties } \\
\text { were resistant and } \\
\text { victors were not } \\
\text { desirable by U.S. New } \\
\text { constitution (Basic Law) } \\
\text { not drafted by Germans } \\
\text { until } 1949 .\end{array}$ & $\begin{array}{l}\text { U.S.-imposed Constitution } \\
\text { at 6-month point, as well } \\
\text { as national elections. } \\
\text { When Japanese appeared } \\
\text { to stall the process, } \\
\text { MacArthur had } \\
\text { occupation forces } \\
\text { implement anyway. }\end{array}$ & $\begin{array}{l}\text { No plan in place until 6- } \\
\text { month point; then four } \\
\text { months spent trying to get } \\
\text { Iraqis to draft a temporary } \\
\text { document and another four } \\
\text { convincing the people to } \\
\text { accept it. Six months to form } \\
\text { a temporary "care-taker" } \\
\text { government. }\end{array}$ \\
\hline
\end{tabular}

It is clear from the above the U.S. was in a reactive state in Iraq from the very beginning. There were no plans to restore the country's sovereignty, and when they were finally developed, they were unrealistic and ignored the lessons of history.

Despite having far too few resources, the CPA tried to accomplish too much in too short a time. Attention should have been put towards security first, or officials needed to accept the danger and get 
essential services operating to show improvement in the daily lives of the people. The U.S. military trains to prepare jets for combat and maintain high operational tempos even while wearing hazmat suits and other protective gear. ${ }^{156}$ Though things may run less efficiently, the message is clear: danger does not stop the mission. Yet, in Iraq, construction would halt at the threat of violence. It should have continued, even if the workmen had to wear body armor. Stopping projects merely gave the insurgents another victory and prolonged other efforts. Continuing the work might have lessened support for the insurgency, which would have helped on the security front and allowed more focus on transitioning to democracy and a market economy. It took Germany and Japan six months to get to this point; the CPA waited less than two, in a far less-stable environment. It lacked both the numbers of boots on the groups and the support of the people, both of which were necessary to accomplish its goals. Finally, it should be noted Germany and Japan were restored to pre-war status and well on their way to being dominant monetary powers in their regions within ten years. More than a decade after the fall of Saddam, Iraq has fallen even farther down the ladder of development than it had in 2008.

The assumptions relied on when planning the military campaign of Iraq were: 1) the combat phase of the operation would be decisive and produce a stable security environment; 2) U.S. forces would be greeted as liberators; 3) Iraq's government ministries would remain intact and continue to administer the country; and 4) local forces would be capable of providing law and order (Kiefer: 22-23). Obviously, the first assumption was not met. Since none of the others came to pass, either, there was no postwar plan for Iraq to be implemented by the commanders and soldiers once they reached Baghdad. The combat phase was estimated to last 135 days; it lasted less than 30 . Planners envisioned one of two scenarios for the post-conflict phase: either large numbers of coalition forces and martial law would be required for years, or the Iraqis would claim the country as their own, organizing themselves swiftly

\footnotetext{
${ }^{156}$ Author's personal knowledge, having spent days in chemical suits while stationed overseas in a non-combat zone.
} 
without coalition help. In addition to the fact there are myriad alternatives within these two extremes, there was not sufficient troop presence for even the first scenario.

Though neither the ORHA nor the CPA had adequate time to prepare, the United States Defense Department did. Facts clearly show plans were developed as early as twenty years prior, but these were scrapped, and offices within the Pentagon and State Department began operating in their own silos during the fall of 2002, with no proper communication between them as to what the post-conflict situation would be, nor even who would be in charge. Post-conflict plans for Germany and Japan were not underway until April 1944, but at that point 72 staff studies started to examine numerous contingency scenarios.

In World War II, the military had oversight of the occupation, but in Iraq, CENTCOM was cut out when the CPA was placed in the lead. Directives from the administration were vague, at best. The August 2002 National Security Policy Directive simply stated the goal was to "preserve, but reform, the current Iraqi bureaucracy" using "the current opposition to Saddam" as the means for accomplishing these objectives. This clearly referred to Chalabi's group, but it is doubtful the U.S. would have been so heavily reliant on a cast-out group of Germans in 1945.

U.S. soldiers never truly engaged with Iraqis in 2003-04. If they had, it might have been possible to identify former soldiers and police officers capable of leading a new force. This is what happened in Germany, where officials were authorized to re-uniform local police within a few weeks. The impact of this engagement was clear: 200 local authorities were operating by July 1945, barely 90 days after Germany's surrender. Even under the burden of de-Baathification, recruiting mid-level officers or highranking enlisted troops in Iraq should have been possible, given the high rate of Shia in the army. Many of these individuals must have possessed strong leadership skills, since they later organized and trained the majority of the insurgency followers. But Bremer prohibited any direct engagement of this sort until proper procedures were in place, in order to avoid the appearance of "direct control", a somewhat 
laughable stance considering what was actually happening. The prevention of these steps was, in itself, an act of control.

There were extremely high numbers of Americans in Iraq, but they were concentrated in large population centers, preventing them from creating any significant grassroots movement.

Communications between Baghdad and Washington happened daily, but messages from Baghdad to the field-as well as the reverse-were often delayed or overlooked due to their sheer volume. At one point, the CPA began censoring the news because its coverage was "anti-occupation". This was pointless, however, when access to the internet provided coverage from international media outlets sharing the same stories. In the end, the censorship merely came across as dictatorial and undemocratic.

U.S. officials repeatedly wait for the "perfect solution" to present itself, rather than accepting the hand they were dealt. Iraqi groups were never permitted to negotiate directly with the UN because CPA staff did not believe those acting as facilitators would be effective, but surely they would have served better than Americans who still did not grasp the culture they were living in. ${ }^{157}$

Americans did not live among the Iraqis, the way soldiers did in 1945. Thus, they never experienced large feelings of goodwill or appreciation. After a few short weeks in Germany, most U.S. troops began to feel a strong desire to take care of the Germans, despite the protocols dictated by Washington and the public pressure to treat all Germans as the enemy. In Iraq, almost the opposite occurred. Troops entered the country NOT viewing every Iraqi as the enemy; they were a people who needed saving from a horrible tyrant. Over time, though, U.S. soldiers became suspicious of nearly every local who approached them, until eventually even those troops arriving in-theatre were antagonistic

\footnotetext{
${ }^{157}$ In 2008, when the author was present in Baghdad for the Sadr City siege, there was no briefing or discussion as to who al Sadr was, or why he was attacking the Green Zone. He was merely a "rabble rouser" who led a random group of insurgents, devoid of politics or principles. If the troops on the ground tasked with defeating him were told the same, it is no wonder his strategy played out so well.
} 
towards the locals. While, given the insurgents' tactic, their caution is understandable, this is hardly the way to build goodwill and support for a new way of life. The feelings of distrust grew on both sides, in a self-perpetuating cycle. While the status of "honorary white nation" may not have been as effective in Iraq as it was in Japan, more work could have been put into highlighting the similarities between the United States-particularly its military-and Iraqi culture. Specifically, there is the importance of family, honor and pride, and a solid work ethic.

Perhaps the most important contribution of this work is the focus on the timing of elections and the drafting of a new constitution, post-conflict. Elections in Iraq were delayed because Bremer and the CPA found the ideologies of certain groups distasteful, choosing instead to wait until more desirable groups could gain power and popularity. In 1945, General Clay chose not to wait, believing the best way to learn democracy was by practicing it. Local elections in smaller cities and towns took place in January 1946, with larger cities following in the spring. This gradual implementation allowed parties to build momentum and enabled the occupation officials to adapt their procedures before large-scale regional elections took place, but even these occurred in April and May of the same year. National elections were postponed until 1949, however, to give the people a chance to experience democracy and decide the direction their country should go. In contrast, MacArthur held general elections in Japan in early 1946; the result was an elected Prime Minister who was quickly purged for militant acts during the war. Though the country was able to continue moving forward, this experience is a cautionary tale about granting high-level power before sufficient time has passed to vet candidates.

There is no clear reason why local elections, at the least, could not have occurred in Iraq in the fall of 2003 or early spring of 2004. The arguments put forth by Bremer do not hold up when compared with the results of 1945 methods. First, Bremer was concerned about the lack of secular political parties. But, as Clay learned in Germany, politics in most countries involves much more than parties and rivalries; political appointees throughout Germany represented social, economic, and religious outlooks, 
in addition to political ones. Special interests, such as the Catholic Church and other cliques, were deciding policy, whether their members held elected office or not. The same situation occurred in Iraq, without the benefit of being supported by a Democratic process. By the time Larry Diamond and other CPA advisors began to conduct talks on democracy, most Iraqis were fearful of the process, believing special interest groups or sheiks would mandate the outcome of any elections. Bremer's hesitancy only reinforced their fears, as he shared them, rather than accepting the fact this is true in most democratic nations, including the United States. Individuals often turn to their group affiliations-included religious leaders - for advice on how to vote. The winners of Germany's first democratic elections were largely Communists and Catholics - two groups loathed in American politics at the time. But their victory sent a swift message to other constituencies: get it together or get out. By the time national elections came about in Germany and Japan, more "desirable" groups had made sufficient headway.

Similar to Japan, when Bremer finally decided to implement an elections process in Iraq, he did so at the national level. Unlike Japan, the procedures were quite protracted, consisting of an appointed government, including the president and prime minister; followed by an elected interim body; followed by a final, permanent elected body. Iraq still had strong political parties in existence in 2003 , as the exiled politicians illustrated. Members of the Interim Governing Council-all 25 of them-were selected based on their political backgrounds (and religion, to a certain extent). Additional groups presented themselves quickly during the summer and fall of 2003. This contrasts with Germany, where occupation officials declared politics to be "dead", and had great difficulty getting any parties to organize. Yet legitimate elections were still carried out within nine months, whereas Iraqis waited more than two years. Bremer and the CPA believed it would take many months to find and appoint Iraqis capable of running elections; in 1945, occupation officials in Germany and Japan simply ran the elections themselves. Another example of a continuing disconnect in Iraq-why was it acceptable to appoint officials, rather than allow local communities to elect them? Why was it not better to directly oversee 
elections and hand operations over to a legitimately elected government, rather than wait months to appoint the "right" people?

There was great contrast in 1945 between actions in Germany and Japan pertaining to the Drafting of a New Constitution. Largely because of growing Cold War concerns, Germany did not have a new democratic constitution until 1949, the same year of its first general elections. Japan, on the other hand, was handed a new constitution by the Americans, who spent only two weeks drafting it. ${ }^{158}$ These two very different methods have both stood the test of time; in fact, Japan's constitution has never been amended. With both examples to learn from, however, Bremer took a different approach in Iraq, one that was again protracted and somewhat pointless.

In Iraq, the first plan was to have the Interim Governing Council draft a new constitution, but by fall 2003, it was clear this was not going to happen quickly. The evidence supports that, had such a body existed in 1945 and drug its feet on such an issue, both Generals Clay and MacArthur would have accomplished the task for them, or replaced them with a more effective body. Instead, Bremer proposed a plan in November 2003 allowing for an interim constitution implemented by an appointed government, who would then oversee two subsequent elections before a permanent constitution was ratified by the people. The CPA then spent months drafting the interim constitution (the TAL) and even longer trying to convince the Iraqis to accept it.

The TAL was meant to be a temporary document, lasting no more than a year, but it was clear all involved meant it to be the template for the permanent document to be drafted later. Weeks were spent debating major issues like human rights, structure of the judiciary, federalism, the executive structure, legislative power, and civil-military relations, when really its main focus should have been the selection process for the transitional assembly government and the transition timetable. So much attention was placed on these controversial, long-term issues the idea of a "caretaker" government had

\footnotetext{
${ }^{158}$ An interesting side note: the U.S. Constitution was written in approximately 100 hours.
} 
to be postponed, which was originally the purpose behind the TAL. Also, weeks were spent just trying to get the Governing Council to write the TAL; no time was allotted for review and comment by civic organizations, professional groups, or local and regional leaders.

Because of the near-secrecy under which it was drafted, the TAL then had to undergo a massive PR campaign to gain public acceptance. These efforts, like so many other CPA plans, fell short of the mark. Hundreds of "educational conversations" were held around the country, attempting to get individual citizens to embrace the TAL. It is unclear why CPA officials were so passionate about public approval for a temporary document, rather than putting more energy into the transition process. Officials in 1945 did not spend nearly as much time debating the political process; instead, they accomplished actual reconstruction tasks that improved the lives of the citizens.

Given the amount of work that went into the TAL, its near-complete rejection by the people, and its replacement less than a year later, it is confusing why Bremer did not merely mandate the country would continue to be governed under the rules established by the CPA until the permanent government was elected. This would have permitted the TAL drafting process to focus on how those elections would be conducted and who would be responsible for them, rather than deciding who would take ownership of the barely-functioning oils fields for the next 12 months. Many point out the TAL was hoped to serve as a guideline for the permanent constitution, but this argument contradicts the presentations by CPA officials that the public should "accept" the TAL and focus on the permanent constitution that would come later. It seems more likely the TAL was a matter of personal pride to Bremer, especially when reading his memoir of his time in Iraq. He insists in his book many times the TAL was in the best interests of the people, but he then had his staff tell them not to be overly concerned with its content, since it was to be replaced the next year. In truth, the TAL allowed the CPA to "check the box": they turned Iraq over to an interim governing body with a democratic set of laws in place. The fact this government looked remarkably similar to the Council that had been in place for 
more than 14 months, and was still heavily dependent on the United States for security and financing, was never mentioned.

\section{Conclusions/Recommendations}

A number of themes presented themselves during the Iraq endeavor: enormous security challenges, dramatic and frequently reactive course-changes in strategy, turbulence engendered by persistent personnel turnover at every level, waste wrought by inadequate contracting and contract management practices, and poor integration of interagency efforts (Bowen: iii). Taken together, they can lead to only one conclusion: the U.S. government was not adequately prepared to carry out the mission it took on in mid-2003, and the people of Iraq paid the price.

One of the most important lessons General Clay's forces learned in 1945, specifically with regard to de-Nazification, but applicable generally-was that, in the long run, if less is attempted, more can be accomplished. The majority of military government officials in 1945 favored an extended period of tutelage before turning authority over to the Germans. Had this approach prevailed, the outcome might have been the same for the overall project as for de-Nazification: a train of increasingly expensive and frustrating programs ending in mutual disappointment. Instead, Clay made democracy as attainable an objective for U.S. forces as it was ever likely to be by placing responsibility where it would ultimately have to lie: the German people. Military commanders also learned a single chain of command is necessary at any particular point, but the structure of the chain may need to change over time. For example, initially, the situation required a tactical command chain as the transition from combat to occupation took place. Eventually, this shifted to more of a territorial arrangement as reconstruction took hold. Finally, as both Germany and Japan illustrate, you must have a secure environment in order to initiate grassroots democratic movements. Individuals in fear of their lives will not organize socially or politically, and will tend to ally themselves with the party in power, regardless of their ideology. 
By trying to initiate democracy without first securing the environment, the United States made a crucial error in Iraq. Ironically, its military power and strength worked against it, as Iraqis struggled to understand why the mighty American military could not stop a rag-tag bunch of former soldiers with no permanent base of operations. It called into question everything CPA officials tried to tell them about the occupation's plan for the country and what the Iraqis' own part would be in those plans.

Some tough decisions were made in Iraq, but tougher ones were ignored. For example, thousands of technocrats and educated citizens of the middle class fled the country after 2003. Perhaps, as in Germany and Japan, migration should have been halted until the country was back on its feet. This also could have prevented the millions of refugees and displaced persons who ended up in the country following the violence. Bottom line: if you're going to occupy, OCCUPY - do it right.

Finally, the U.S.'s economic strength was never used properly, both out of fear of public support at home and from mismanagement. Reports show only $27 \%$ of any funding actually went to reconstruction efforts; security, contractor profit, and fraud were perpetual budget line items. Foreign contractors were not used in World War II-the Germans and Japanese were expected to do things for themselves. Had this occurred in Iraq, everyday citizens would have been earning wages by mid-2003, and those wages would not have distorted the labor market. The U.S. attempted to help localities by overpaying for menial jobs like trash removal and sanitation, and this discouraged private enterprise and artificially inflated salaries. Occupation officials sought quick results through hand-outs, without providing a hand-up that would last after they rotated out of the country. Given the ultimate expense of the war, paying government workers' and military soldiers' salaries from the beginning-as Rumsfeld refused to do-would have kept those individuals at their posts and busy, as well as removed their major motivation for supporting or joining the insurgencies and militias.

This research strives to illustrate the factors predominantly used to defend the U.S.'s failures in Iraq are misleading - the discrepancies noted between these factors as they existed in Iraq compared to 
other occupations are not comparing similar time frames and/or gloss over the pertinent truths. The fact remains, occupation officials overcame far greater obstacles in 1945 than they failed to hurdle in 2003. Most U.S. troops were in Germany and Japan less than a year, but an effective training regimen was implemented, as well as clear and concise instructions for accomplishing the mission. More importantly, U.S. military commanders understood the culture they were living in. Officials in Iraq forgot this most basic concept of counter-insurgency: know the roots of the insurgency; how it manifests is secondary. We chose to put most of our efforts into dealing with the latter.

Bremer and his staff frequently touted the Iraqis had unrealistic expectations, given the lack of security. We were then unwilling to endanger American lives (past a certain extent) to correct the situation, and refused to provide the Iraqis money and resources to do it themselves, even thwarting them when they made the attempt. And the Iraqis' demands were not unexpected or unusual: they asked for clean water, working sewage lines, and reliable electrical power-all things they had under the evil dictator from whom we claimed to be rescuing them. The author is not asserting American lives should be sacrificed in large numbers, or that we should simply throw money at local governments; rather, this entire work is dedicated to pointing out the thought process and acceptance of risk-both monetary and life-that must occur before such a tremendous effort at nation-building can take place.

Hindsight can be $20 / 20$, and this work has attempted to highlight factors that should have been known - and, in many instances, were known-and appreciated by Defense and State Department officials prior to the Iraq invasion, based largely on experiences learned in 1945-46. Also, the author realizes her personal experiences in all three of these nations have likely caused a level of observer bias; however, this bias is derived from actual experiences in these countries, and having lived through the results of the Japanese and Iraq occupations. Should the United States again attempt an invasive or conflict-based occupation on such a large scale, its initial objectives should remain those advanced by most subject-matter experts in 2003: maintain the solidifying institutions within the nation, and keep 
the government structure intact. Officials can then decide to govern directly or work through existing channels.

It seems clear-depending on which "truths" one relies on-any country could be found lacking in the Contextual Factors presented in this paper. But, as shown, a Western European nation, an Asian empire, and a Middle Eastern dictatorship had significant similarities across time and space.

Where they differed was the approach taken by the same occupying nation, one whose subsequent generation of leaders failed to heed the lessons of the past. It does not appear Iraq suffered as many innate deficiencies as most historians and scholars lead people to believe; rather, when factors are compared across the same time span, without attempting to use them as excuses for failure, the similarities between a Western nation, an Asian empire, and an Arab regime became far more apparent. It can only be hoped future administrative officials, military commanders, and world leaders remember the case of Iraq, and hold dear the lessons learned within its borders: occupation is not pretty, nor is it a popularity contest. The benefits of its success can include extreme economic strength and stability, while its failure can lead to disaster. 


\section{BIBLIOGRAPHY}

Al Khajafi, Isam. "The Myth of Iraqi Exceptionalism", Middle East Policy Journal, Vol 7, Issue 4, pp 62-91: 2003.

Al Khajafi, cited in Matt Margolis and Mark Noonan. Caucus of Corruption: The Truth About the New Democratic Majority. World Ahead Media, Los Angeles: 2007; and in Jeff Bridoux. American Foreign Policy and Post-war Reconstruction: Comparing Japan and Iraq. Routledge Taylor and Francis Group, London and NY: 2011.

Al Marashi, Ibrahim. "Toward an Understanding of Media Policy and Media Systems in Iraq", CGCS Occasional Paper Series, 1. Retrieved from http://repository.upenn.edu/asc papers/59.

Allied Control Authority. "Enactment and Approved Papers of the Control Council and Coordinating Committee". Germany: 1945, available at https://www.loc.gov/rr/frd/Military Law/enactmentshome.html.

Andrews, Edmund L. "Envoy's Letter Counters Bush on Dismantling of Iraq's Army", The New York Times: September 4, 2007.

Aylwin-Foster, Nigel. "Changing the Army for Counterinsurgency Operations", Military Review, Nov-Dec 2005.

Bacevich, Andrew J. Washington Rules: America's Path to Permanent War. American Empire Project, Metropolitan Books: 2010.

Banerjee, Abhijit. Growth Theory Through the Lens of Development Economics. Massachusetts Institute of Technology: 2004.

Barnett, Correlli. "Post-conquest Civil Affairs: Comparing War's End in Iraq and Germany", Foreign Policy Centre, London: February 2005.

Barton, Frederick D. and Bathsheba Crocker. "Winning the Peace in Iraq", The Washington Quarterly, Vol 26, Issue 22: 2003.

Beasley, W.G. The Rise of Modern Japan. St. Martin's Press, New York: 1990.

Bellin, Eva. "The Iraqi Intervention and Democracy in Comparative Historical Context", Political Science Quarterly, Vol 119, N 4: 2004-05.

Benashel, Nora. "Mission Not Accomplished: What Went Wrong With Iraq Reconstruction", Journal of Strategic Studies, vol 29, Issue 3, pp 453-473: 2008.

Bowen, Glen A. "Document Analysis as a Qualitative Research Method", Qualitative Research Journal, vol 9, Issue 2: 2009.

Bowen, Stuart. Applying Iraq's Hard Lessons to the Reform and Reconstruction of Stabilization Operations. Office of the Special Inspector General for Iraq Reconstruction: 2010, available at 
https://cybercemetery.unt.edu/archive/sigir/20131001150850/http://www.sigir.mil/files/USOCO/Cover FrontHiResUSOCO.jpg.

Bremer, L. Paul, III and Malcom McConnell. My Year in Iraq: The Struggle to Build a Future of Hope. Threshold Editions: November 21, 2006.

Bridoux, Jeff. American Foreign Policy and Post-war Reconstruction: Comparing Japan and Iraq. Routledge Taylor and Francis Group, London and NY: 2011.

Carafano, James Jay. Waltzing Into the Cold War: The Struggle for Occupied Austria. Texas A\&M University Press, College Station: 2002.

Casella, Alexander. "Occupying Iraq: The Lessons of History." Asia Times Online. July 18, 2003. URL: http://www.atimes.comlatimesIMiddle EastlEGI8Ak04.html. Accessed January 11, 2009

Clay, Lucius D. Decision in Germany. Double-Day Books, New York: 1950.

Cohen, Theodore. Remaking Japan: The American Occupation as the New Deal. Studies of the East Asian Institute, University of Michigan Free Press: 1987.

Collings, Justin. Democracy's Guardian: A History of the German Federal Constitutional Court, Oxford; OUP, pp 287: 2015.

Cordesman, Anthony H. "The Lessons of the Iraq War", A Report of the Center for Strategic and International Studies, Eleventh Working Draft: July 21, 2003. Available at https://csisprod.s3.amazonaws.com/s3fs-public/legacy files/files/media/csis/pubs/iraq instantlessons.pdf.

Craig, Barbara H. "The Power to Make War: Congress' Search for an Effective Role", Journal of Policy Analysis and Management, vol 1, Issue 1, pp 317-332: Spring 1982.

Crane, Conrad C. Reconstructing Iraq: Insight, Challenges, and Missions for Military Forces in a PostConflict Scenario, A Report for the Strategic Studies Institute: February 2003.

Desch, Michael C. "Bush and the Generals", Foreign Affairs. The Council on Foreign Relations: 2007, available at https://www.foreignaffairs.com/articles/united-states/2007-05-01/bush-and-generals.

Diamond, Larry. Squandered Victory: The American Occupation and the Bungled Effort to Bring Democracy to Iraq. Times Books, Henry Holt and Company, New York: 2005.

Dobbins, James, John G. McGinn, Keith Crane, Seth G. Jones, Rollie Lal, Andrew Rathmell, Rachel M. Swanger, and Anga R. Timilsina. "America's Role in Nation-Building: From Germany to Iraq". RAND Corporation, Santa Monica, CA: 2003.

Dodge, Toby. Inventing Iraq: The Failure of Nation-Building and a History Denied. Sage Publications Limited, Canada: 2003.

Dower, John W. Embracing Defeat: Japan in the Wake of World War II. W.W. Norton and Company: 1999. 
Dower, John W. “Don't Expect Democracy This Time: Japan and Iraq", Policy Papers, 1 April 2003.

Dower, John W. and C. S. Maier. "Comparative Insights: Marshall Plan, Japan, and Iraq", Lecture in The Politics of Reconstructing Iraq, an event organized by the Department of Urban Studies and Planning, MIT, 7 March. Available at www.mitworld.mit.edu/video/255.

Dreyfuss, Robert. Devil's Game: How the United States Helped Unleash Fundamental Islam. American Empire Project, Metropolitan Books: 2005.

Emmerson, John K. and Harrison M. Holland. The Eagle and the Rising Sun: American and Japan in the $20^{\text {th }}$ Century. Addison-Wesley, Reading, MA: 1988.

Energy Information Administration Country Report on Iraq: 2007. Available at https://www.eia.gov/beta/international/analysis.cfm?iso=IRQ.

Face the Facts USA: A Project of the George Washington University, www.facethefacts.org, "U.S. Spends More Rebuilding Iraq, Afghanistan Than Post-War Germany", January 18, 2013.

Fallows, James. "Blind into Baghdad", The Atlantic, Jan/Feb 2004 Issue.

Feith, Douglas J. Congressional Testimony on Post-War Planning, February 11, 2003, available at https://www.centerforsecuritypolicy.org/2003/02/11/post-war-planning-2/.

Feldman, Noah. What We Owe Iraq: War and the Ethics of Nation-building. Princeton University Press, NJ: 2006.

Franks, Tommy. American Soldier. William Morrow Paperbacks: 2005.

Freitag, Simone, Silke Schmidt, Elmar Braehler, and Heidi Glaesmer. "The Impact of Forced Displacement in World War II on Mental Health Disorders and Health-Related Quality of Life In Late Life-A German Population-Base Study", International Psychogeriatrics, vol 25, Issue 2, pp 310-319: 2013.

Fukuyama, Francis. "After Neoconservatism”, New York Times Magazine, February 19, 2006.

Funabashi, Y. "China's Long-term Strategy: Peaceful Ascendancy”, International Herald Tribune, Dec 2, 2003.

Galbraith, Peter. The End of Iraq: How American Incompetence Created a War without End. Simon and Schuster: 2006.

Gewertz, Ken. "US Occupations Compared by Panel", Harvard News Office, Harvard Gazette Archives, March 18, 2004. (Dower and Maier panelists)

Ghabra, Shafeeq N. "Iraq's Culture of Violence", Middle East Quarterly: Feb 24, 2009.

Gordon, Michael R. and General Bernard E. Trainor. COBRA II, The Inside Story of the Invasion and Occupation of Iraq. New York: Pantheon Books, 2006. 
Gott, Kendall D, and Michael G Brooks. Warfare in the Age of Non-State Actors: Implications for the U.S. Army. Combat Studies Institute Press, Ft Leavanworth, KS: 2007.

Gott and Brooke, cited in Trevor Royle's Lessons in Leadership from the Soldier's General. Palgrave MacMillan, NY: 2010, p. 57.

Gramsci, Antonio. Selections from the Prison Notebooks of Antonio Gramsci. International Publishers, NY: 1971.

Grew, Joseph C. "Report from Tokyo", Life, Dec 7, 1942, p 79. Retrieved November 23, 2011.

Halper, Stefan and Jonathan Clarke. American Alone: The Neoconservatives and the Global Order. Cambridge University Press: 2005.

Harmon, E. N. Combat Commander: Autobiography of a Soldier. Prentice Hall, Englewood, NJ: 1970

Hendrickson, David C. and Robert W. Tucker. "Revisions in Need of Revising: What Went Wrong in Iraq", A Report of the Strategic Studies Institute. U.S. Army War College, PA: 2005.

Hippler, Jochen, "Nation-Building by Occupation: The Case of Iraq", Nation-Building - A Key Concept of Peaceful Conflict Transformation. London, Pluto Press: 2005.

Hirakawa, Sukehiro. "Japan's Turn to the West", The Cambridge History of Japan, Volume 5. Cambridge University Press: 1989.

Horne, Alistair. A Savage War of Peace: Algeria 1954-62. Penguin Books, Limited: 1977.

Jennings, Ray Salvatore. "The Road Ahead: Lesson in Nation-Building from Japan, Germany, and Afghanistan for Postwar Iraq", Peaceworks No 49. United States Institute for Peace, Washington, DC: April 2003.

Joint Chiefs of Staff Directive 1067: Directive to Commander-in-Chief of United States Forces of Occupation Regarding the Military Government of Germany, 1945. Available at http://germanhistorydocs.ghi-dc.org/sub document.cfm?document id=2297.

Jones, Robert C. "Understanding Insurgency: The Condition Behind the Conflict", Small Wars Journal. Small Wars Foundation, smallwarsjournal.com: 2011.

Keifer, Allen W. "Lessons Forgotten: Comparing the Occupation of Germany with Iraq", U.S. Army War College Strategy Research Project, Carlisle Barracks, PA: 2009.

Killick, Tony. "Principals, Agents, and the Failings of Conditionality", Journal of International Development, vol 9, Issue 4, pp 483-495: June 1997.

Kommers, Donald P. The Constitutional Jurisprudence of the Federal Republic of Germany, Duke University Press, p. 309: 2012. 
Lasseter, Tom. "In the Face of Stubborn Insurgency, Troops Scale Back Anbar Patrols", Knight Ridder Newspapers: July 20, 2004.

MacArthur, Douglas. Reports of Douglas MacArthur. U.S. Government Print Office, Washington, DC: 1966.

Maddison, Angus. Historical Statistics for the World Economy. OECD Development Center, Paris: 2003.

Mansoor, Peter. Baghdad at Sunrise: A Brigade Commander's War in Iraq. Yale University Press, New Haven, CT: 2009.

Marr, Phebe. The Modern History of Iraq, $3^{\text {rd }}$ Ed. Westview Press, Philadelphia: 2012.

Marrus, Michael. The Unwanted: European Refugees in the Twentieth Century. Oxford University Press, London: 1985.

Maulucci, Thomas, Jr. "Comparing the American Occupations of Germany and Iraq", Yale Journal of International Affairs, Winter 2008, p 120.

McCreedy, Kenneth. Waging Peace: Operation Eclipse I and II - Some Implications for Future Operations. U.S. Army War College, Carlisle Barracks, PA: 2004.

McGrath, JJ. Boots on the Ground: Troop Density in Contingency Operations. Combat Studies Institute Press, Fort Leavenworth, KS: 2006.

Merom, Gil. How Democracies Lose Small Wars. Cambridge University Press, NY: 2003.

Moore, Ray A. and Robinson, Donald L. Partners for Democracy: Crafting the New Japanese State Under MacArthur. Oxford University Press: 2004.

Nakash, Y. "The Shiites and the Future of Iraq", Foreign Affairs: July/August 2003.

National Security Presidential Directive XX, "Authorizing Training for Iraqi Opposition Forces", October 3, 2002.

Norton-Taylor, Richard. "Memo to Mendacity", The Guardian: April 18, 2004.

Papavassiliou, Dimitra. Achieving Social Cohesion in Iraqi Nation Building, whydev.org: January 26, 2017.

Peterson, Edward Norman. The American Occupation of Germany: Retreat to Victory. Wayne State University Press: 1977.

Rathmell, Andrew. "Planning Post-Conflict Reconstruction in Iraq: What Can We Learn?", Journal of International Affairs, vol 81, Issue 5; pp 1013-1038: Oct 2005.

Record, Jeffrey. Beating Goliath: Why Insurgencies Win. Potomac Books, Inc, Washington, DC: 2007.

Reese, S. D. "The Framing Project: A Bridging Model for Media Research Revisited", Journal of Communication, vol 57, Issue 1, pp. 148-54: 2007. 
Reischauer, Edwin O., A. M. Craig, and John King Fairbank. Japan: Tradition and Transformation. Allen and Unwin, 2d ed: October 1, 1989.

Ricks, Thomas E. Fiasco: The American Military Adventure in Iraq. Penguin Books, NY: 2006.

Ricks, Thomas E. The Gamble: General Petraeus and the American Military Adventure in Iraq. Penguin Group, New York, NY: 2009.

Robinson, William. Promoting Polyarchy: Globalization, U.S. Intervention, and Hegemony. Cambridge University Press, NY: 1996.

Schaller, Michael. The American Occupation of Japan: The Origins of the Cold War in Asia. Oxford University Press: 1985.

Schonberger, Howard B. Aftermath of War: Americans and the Remaking of Japan, 1945-1952. The Kent State University Press, Kent, $\mathrm{OH}$ and London, England: 1989.

Serafino, Nina, Curt Tarnoff, and Dick K. Nanto. "U.S. Occupation Assistance: Iraq, Germany, and Japan Compared". CRS Report for Congresss: March 23, 2006.

Shinichiro, Takakura. "The Ainu of Northern Japan: A Study in Conquest and Acculturation", Independence Square: The American Philosophical Society. pp. 24-25: 1960.

Small Arms Survey. Rights At Risk. Graduate Institute of Geneva, Switzerland: 2004. English version available at http://www.smallarmssurvey.org/publications/by-type/yearbook/small-arms-survey2004.html.

Snyder, James M. "The Established and Operations of the United States Constabulary, 3 October 194530 June 1947", Headquarters U.S. Constabulary Historical Sub-Section C-3: 1947.

Special Inspector General for Iraq Reconstruction (Stuart Bowen). "Quarterly Reports and Semi-Annual Reports to the United States Congress", found in Hard Lessons: The Iraq Reconstruction Process, available at www.sigir.mil.

Tariq, Ali. Bush in Babylon: The Recolonization of Iraq. Verso Publishing, London: 2003.

Tarnoff, Curt. "Iraq: Recent Developments in Reconstruction Assistance", CRS Report for Congress. May 5, 2006, Updated 2009. Available at https://digital.library.unt.edu/ark:/67531/metacrs10442/.

Terrill, Andrew W. and Conrad C. Crane. Reconstructing Iraq: Insights, Challenges, and Missions for Military Forces in a Post-Conflict Scenario. Strategic Studies Institute: 2003.

Tripp, Charles. A History of Iraq. Cambridge University Press, 3d, London: 2007.

Toshio, Kuroda. "Aging of the Population of Japan: Prospects and Challenges", Chapter 1 in Population Aging in Japan: Problems and Policy Issues in the 21 ${ }^{\text {st }}$ Century. Tokyo: 1982. 
UNDG/World Bank Group, "Report to Core Group in Iraq": 2004. Available at http://web.worldbank.org/archive/website01034A/WEB/0 CO-57.HTM.

United States Government Accountability Office, Report to Congressional Committees. "Securing, Stabilizing, and Rebuilding Iraq: Iraqi Government Has Not Met Most Legislative, Security, and Economic Benchmarks": September 2007.

United States Strategic Bombing Survey Summary Report (European War), Washington, DC: September 30, 1945.

United States Strategic Bombing Survey Summary Report (Pacific War), Washington, DC: 1 July 1946.

U.S. Army Field Manual 3-24: Counterinsurgency, Headquarters Department of the Army: December 15, 2006.

U.S. Department of State, "Statement by the Governments of the United Kingdom, the United States of America, the Union of Soviet Socialist Republics and the Provisional Government of the French Republic on Control Machinery in Germany". Allied Policies, 1944-45: Published 1947, available at http://germanhistorydocs.ghi-dc.org/sub document.cfm?document id=2298.

Van Bruinessen, M. "Religion in Kurdistan", Hum.uu.nl. Retrieved 10 Nov 2017.

Van Buren, Peter. We Meant Well: How I Helped Lose the Battle for the Hearts and Minds of the Iraqi People. American Empire Project, Metropolitan Books: 2011.

Weiler, Robert S. "Eliminating Success During Eclipse II: An Examination of the Decision to Disband the Iraqi Military", Master's Thesis, United States Marine Corps Command and Staff College: AY-09.

Weintraub, Jeff. "The American War In Iraq Trails Off", Commentaries and Controversies. Available at http://jeffweintraub.blogspot.com/2010/01/american-war-in-iraq-trails-off.html.

Westney, Eleanor D. Imitation and Innovation: The Transfer of Western Organizational Patterns to Meiji Japan. Harvard University Press, Cambridge, MA: 1987.

Wolfe, Robert. Americans as Proconsuls: United States Military Government in Germany and Japan, 1944-1952. Southern Illinois University Press: 1984.

Wong, Edward and lan Fisher. "Wary Iraqis Welcome the Handover But Ask, Now What?", New York Times, June 28, 2004.

Woodward, Bob. Plan of Attack: The Definitive Account of the Decision to Invade Iraq. Simon \& Schuster: October 11, 2004.

Woodward, Bob. State of Denial: Bush at War, Part III. Simon \& Schuster: September 3, 2007.

Working Security Committee. "Provisions for Imposition Upon Germany at the Time of Surrender", Foreign Relations of the United States Diplomatic Papers, Volume 1: 1944. 
Wright, Sarah H. "Comparisons of Iraq to Post-War Japan Fail, Historian Asserts", MIT News, March 16, 2005.

Ziemke, Earl F. The U.S. Army in the Occupation of Germany, 1944-46. Center for Military History, United States Army, Washington, DC: 1975. 